\title{
Topology-Based Functionalization of Robust Chiral Zr-Based Metal-Organic Frameworks for Catalytic Enantioselective Hydrogenation
}

Hong Jiang, Wenqiang Zhang, Xing Kang, Ziping Cao, Xu Chen, Yan Liu* and Yong Cui*

School of Chemistry and Chemical Engineering, Frontiers Science Center for Transformative Molecules and State Key Laboratory of Metal Matrix Composites, Shanghai Jiao Tong University, Shanghai 200240, China

Email: yongcui@sjtu.edu.cn; liuy@sju.edu.cn.

\section{Table of Content}

1. Material and general procedures

2. Synthesis

3. General procedure for catalysis

4. Table S1. Dye inclusion experiments

5. Figure S1. TGA curves

6. Figure S2. CD spectra

7. Figure S3. FT-IR spectra

8. Table S2. Crystal data and structure refinement

9. Table S3. Selected bond lengths and angles

10. Figures S4-S6. Additional X-ray crystallographic structures

11. Figure S7. Additional PXRD patterns

12. Figure S8. $\mathrm{N}_{2}$ adsorption isotherms and BET plots

13. Figure S9. Photographs and SEM images

14. Table S4. Additional catalytic results

15. Figure S10. Kinetic curves

16. Figure S11. Molecular simulations of large substrates

17. Figures S12-S23. Additional NMR spectra

18. Figure S24. HPLC and NMR spectra of catalysis

19. Figure S25. MS spectra

20. References 


\section{Materials and general Procedures.}

All of the chemicals are commercial available, and used without further purification. Elemental analysis of $\mathrm{C}$ and $\mathrm{H}$ were performed with an EA1110 CHNS-0 CE elemental analyzer. The FT-IR ( $\mathrm{KBr}$ pellet) spectra were recorded $\left(400-4000 \mathrm{~cm}^{-1}\right.$ region) on a Nicolet Magna 750 FT-IR spectrometer. The CD spectra were recorded on a J-800 spectropolarimeter (Jasco, Japan). Thermogravimetric analyses (TGA) were carried out in a $\mathrm{N}_{2}$ atmosphere with a heating rate of 10 ${ }^{\circ} \mathrm{C} /$ min on a thermogravimetric analyzer (Q5000IR). Powder X-ray diffraction (PXRD) data were collected on a D8 Advance diffractometer using $\mathrm{Cu} \mathrm{K} \alpha$ radiation. The calculated PXRD patterns were produced using the Mercury program and single crystal reflection data. ${ }^{1} \mathrm{H}$ and ${ }^{13} \mathrm{C}$ NMR experiments were carried out on a MERCURYplus 400 spectrometer operating at resonance frequencies of $400 \mathrm{MHz}$ or Bruker 500 spectrometer operating at resonance frequencies of 500 MHz. Solid state ${ }^{31} \mathrm{P}$ and ${ }^{13} \mathrm{C}$ NMR was performed at Bruker avance $600 \mathrm{MHz}$ wide cavity solid state NMR spectrometer. Mass spectra were recorded on a Finnigan LCQ mass spectrometer or fourier transform ion cyclotron resonance mass spectrometer. Analytical high performance liquid chromatography (HPLC) was performed on a LC-2010A HT (Shimadzu) with UV detection. $\mathrm{N}_{2}$ gas adsorption isotherms of CMOFs were measured using a Micrometritics ASAP 2020 system at $77 \mathrm{~K}$ with liquid $\mathrm{N}_{2}$ bath. Briefly, the fresh crystals were washed by DMF for three times, then exchanged by acetone for three times. Once the exchange was completed, the crystals were evacuated by dynamic pump for $10 \mathrm{~h}$ at $100^{\circ} \mathrm{C}$.

Single-crystal X-ray diffraction. Single-crystal XRD data for $\mathbf{M e}_{4} \mathbf{L}^{\mathbf{1}}-\mathbf{P}-\mathrm{Ir}, \mathbf{1}^{\text {flu }}, \mathbf{2}^{\text {flu }}$ and $\mathbf{1}^{\text {ith }} \mathbf{3}^{\text {ith }}$ were collected on a Bruker Apex X-ray diffraction equipped with Mo-K $\alpha(\lambda=0.71073 \AA)$ or $\mathrm{Cu}-\mathrm{K} \alpha(\lambda=1.54178 \AA)$ sealed-tube X-ray source at 298 or $173 \mathrm{~K}$. For $\mathbf{1}^{\text {flu }}$ and $\mathbf{2}^{\text {flu }}$, the best fit of the systemic absences and the $\left|E^{2}-1\right|$ value $(0.942$ and 1.063$)$ are given by the centrosymmetric Fmmm space group. However, this space group cannot be strictly correct because it contains symmetry elements that are incompatible with the enantiopure biphenol ligand. The chiral space group $P 2{ }_{1} 2_{1} 2_{1}$ is also a viable choice. However, the refinement was still carried out in Fmmm for the following reasons: 1) The biphenol ligand is highly symmetric, and the X-ray cannot differentiate $\mathrm{C}$ and $\mathrm{O}$ atoms at the center phenyl rings. 2) Refinement in $F \mathrm{mmm}$ resulted in reasonable bond length values. However, refinement in $P 2{ }_{1} 2_{1} 2_{1}$ resulted in an unstable model. Thus, the Fmmm space group was used for $1^{\text {flu }}$ and $2^{\text {flu }}$ on the basis of the above discussion. The empirical absorption correction was applied by using the SADABS program (G. M. Sheldrick, SADABS, program for empirical absorption correction of area detector data; University of Götingen, Götingen, Germany, 1996). All the structures were solved using direct method, and refined by full-matrix least-squares on $F^{2}$ by the SHELXTL-2015 software package. DFIX, SADI, FLAT, DANG, EADP and SIMU restrains were used to obtain reasonable parameters due to the poor quality of crystal data. The contributions of highly disordered solvents were removed using SQUEEZE routine PLATON software or the solvent mask program of Olex2. The large R indices of $2^{\text {ith }}$ results from its poor diffraction and twin structure. Crystal data and refinement results are shown in Table S2, while the selected bond distances and angles are presented in Table S3. The CIF files have been deposited in the Cambridge Crystallographic Data Centre (CCDC) under deposition number 1939495 (Me $\left.4 \mathbf{L}^{\mathbf{1}}-\mathbf{P}-\mathbf{I r}\right), 1978379\left(\mathbf{1}^{\text {flu }}\right), 1976028\left(\mathbf{2}^{\text {flu }}\right), 1976029\left(\mathbf{1}^{\text {ith }}\right), 1976030$ $\left(2^{\text {ith }}\right)$, and $1976031\left(3^{\text {ith }}\right)$. 


\section{Synthesis}

\subsection{Synthesis of $(S)-\mathrm{H}_{4} \mathrm{~L}^{1}$}

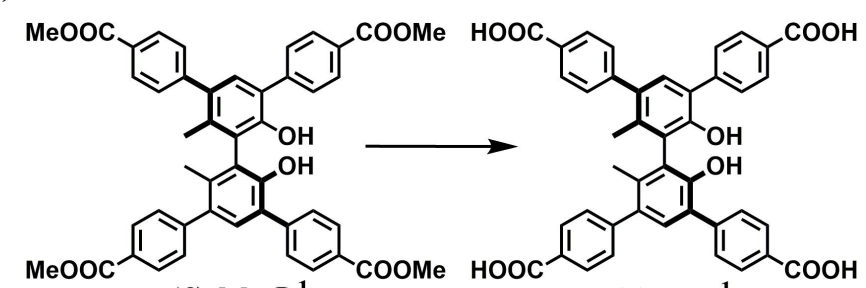

$(S)-\mathrm{Me}_{4} \mathbf{L}^{1}$

$(S)-\mathrm{H}_{4} \mathbf{L}^{1}$

$(S)-\mathrm{Me}_{4} \mathbf{L}^{1}$ was synthesized according to our previous report ${ }^{1}$.

Synthesis of $(\boldsymbol{S})-\mathbf{H}_{4} \mathbf{L}^{1}$. A solution of $(S)-\mathrm{Me}_{4} \mathbf{L}^{1}(2.5 \mathrm{~g}, 3.3 \mathrm{mmol})$, and $\mathrm{LiOH} \cdot \mathrm{H}_{2} \mathrm{O}(1.4 \mathrm{~g}, 33$ mmol) in THF $(15 \mathrm{~mL}), \mathrm{MeOH}(45 \mathrm{~mL})$ and $\mathrm{H}_{2} \mathrm{O}(45 \mathrm{~mL})$ was heated at $75{ }^{\circ} \mathrm{C}$ for $6 \mathrm{~h}$. The solution was cooled to room temperature, acidified to $\mathrm{pH}=1 \sim 2$ with $6 \mathrm{M} \mathrm{HCl}$ and extracted with EtOAc. The organic phase was dried over $\mathrm{Na}_{2} \mathrm{SO}_{4}$ and the solvent was evaporated under reduced pressure to give $(\boldsymbol{S})-\mathrm{H}_{4} \mathbf{L}^{1}$ as a white solid $(2.1 \mathrm{~g}, 91 \%) .{ }^{1} \mathrm{H}$ NMR (500 MHz, DMSO- $\left.d^{6}\right) \delta 12.96$ (br, 4H), 8.33 (br, 2H), 8.00 (dd, $J=11.1,4.3 \mathrm{~Hz}, 8 \mathrm{H}), 7.77$ (d, $J=7.5 \mathrm{~Hz}, 4 \mathrm{H}), 7.55$ (d, $J=8.3$ $\mathrm{Hz}, 4 \mathrm{H}), 7.24(\mathrm{~s}, 4 \mathrm{H}), 1.94$ (s, 6H). ${ }^{13} \mathrm{C}$ NMR (126 MHz, DMSO-d $\left.{ }^{6}\right) \delta 167.56,167.51,151.58$, 146.31, 143.33, 135.44, 133.31, 131.10, 129.81, 129.54, 129.34, 129.08, 129.05, 126.08, 126.05, 18.04. Elemental analysis: Calcd for $\mathrm{C}_{43} \mathrm{H}_{30} \mathrm{O}_{10}$. C: $72.62, \mathrm{H}, 4.35$; Found: $\mathrm{C}, 72.59, \mathrm{H}, 4.39$. ESI-MS: m/z 693.1752 (Calcd m/z 693.1761 for $\left.\left[\mathrm{H}_{4} \mathbf{L}^{1}-\mathrm{H}\right]^{-}\right)$.

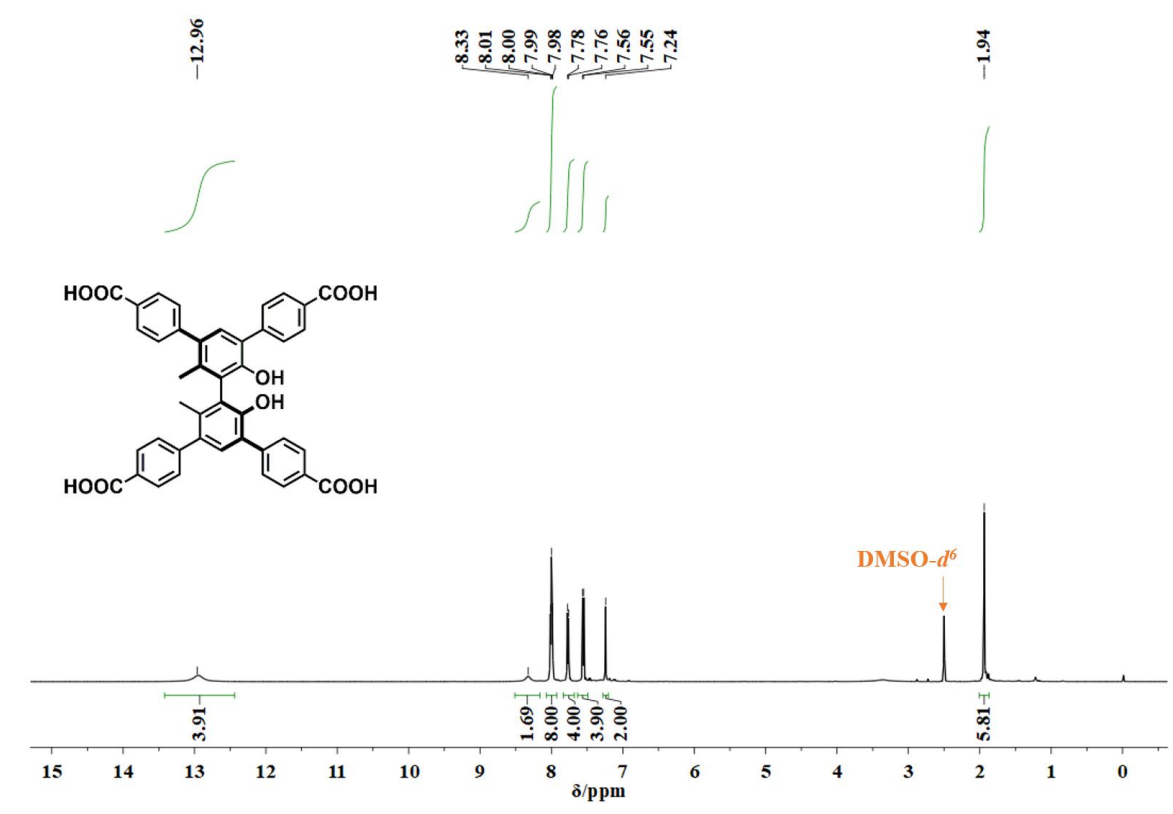




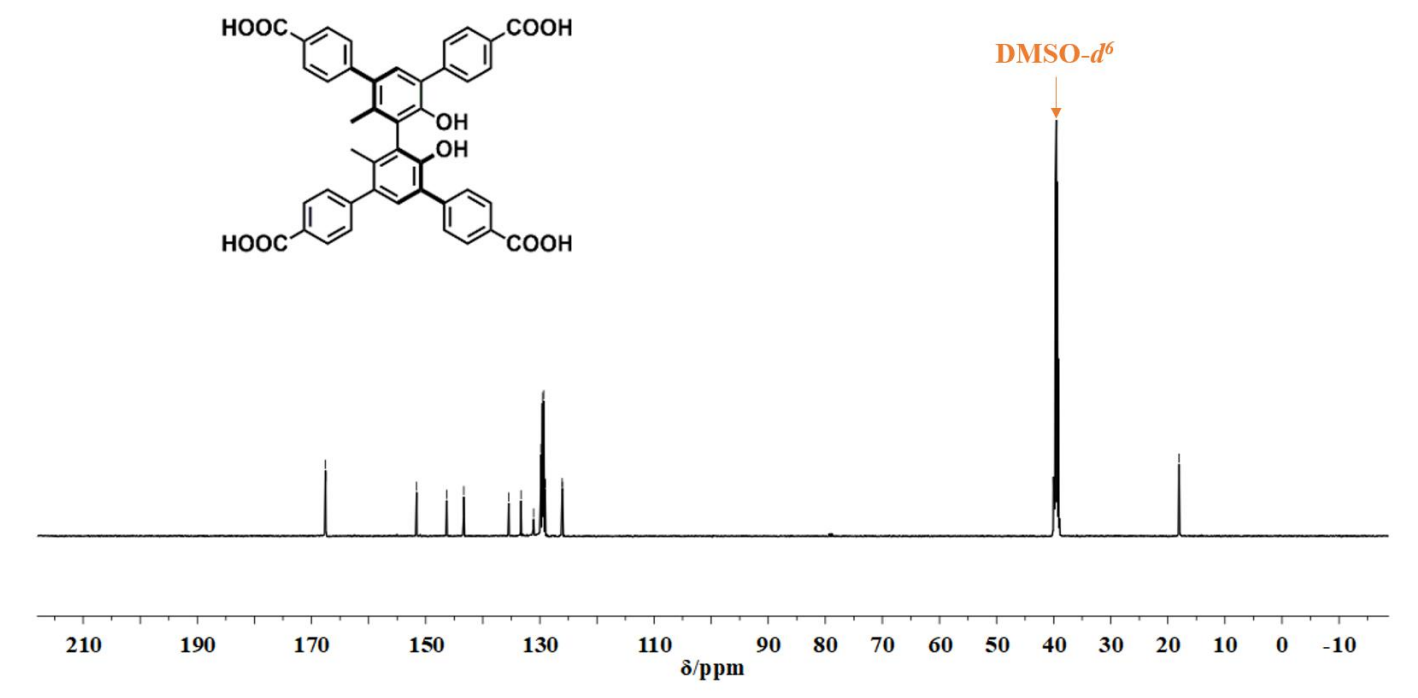

2.2 Synthesis of $(S)-\mathrm{H}_{4} \mathrm{~L}^{2}$

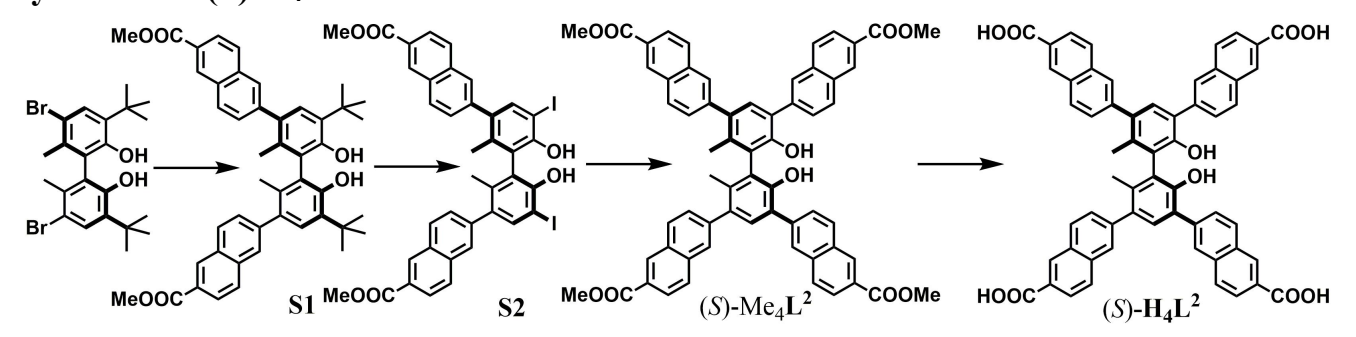

Synthesis of S1. A $100 \mathrm{~mL}$ flame-dried round-bottom flask was charged with (S)-5,5'-dibromo-3,3'-di-tert-butyl-6,6'-dimethyl-1,1'-biphenyl-2,2'-diol (912 mg, 2 mmol), methyl 6-(4,4',5,5'-tetramethyl-1,3,2-dioxaborolan-2-yl)-2-naphthoate (1.87 g, $6 \mathrm{mmol}), \mathrm{K}_{2} \mathrm{CO}_{3}(2.76 \mathrm{~g}$, $20 \mathrm{mmol}), \mathrm{Pd}(\mathrm{dppf}) \mathrm{Cl}_{2} \cdot \mathrm{CH}_{2} \mathrm{Cl}_{2}(82 \mathrm{mg}, 0.1 \mathrm{mmol})$. The mixture was degassed for three times, and then degassed mixture solvents of $45 \mathrm{~mL} \mathrm{DME} / \mathrm{H}_{2} \mathrm{O}(\mathrm{v} / \mathrm{v}=2 / 1)$ were added. The suspension was heated at $95{ }^{\circ} \mathrm{C}$ for $24 \mathrm{~h}$. After cooling to room temperature, the resulting mixture was extracted with $\mathrm{CH}_{2} \mathrm{Cl}_{2}$. The combined organic extracts were washed with water, dried over $\mathrm{Na}_{2} \mathrm{SO}_{4}$, and then concentrated under reduced pressure. The crude solid was purified by column chromatography on silica gel (EtOAc/petroleum ether, 1:15, v/v, $\mathbf{R}_{\mathrm{f}}=0.23$ ) to afford $\mathbf{S} 1$ as a white solid (1.1 g, 80\%). ${ }^{1} \mathrm{H}$ NMR (400 MHz, $\left.\mathrm{CDCl}_{3}\right) \delta 8.66(\mathrm{~s}, 2 \mathrm{H}), 8.10(\mathrm{dd}, J=8.6,1.6 \mathrm{~Hz}, 2 \mathrm{H}), 8.00$ $(\mathrm{d}, J=8.5 \mathrm{~Hz}, 2 \mathrm{H}), 7.92(\mathrm{~d}, J=8.7 \mathrm{~Hz}, 2 \mathrm{H}), 7.86(\mathrm{~s}, 2 \mathrm{H}), 7.58(\mathrm{dd}, J=8.4,1.6 \mathrm{~Hz}, 2 \mathrm{H}), 7.37(\mathrm{~s}$, 2H), 5.25 (s, 2H), $4.00(\mathrm{~s}, 6 \mathrm{H}), 1.97(\mathrm{~s}, 6 \mathrm{H}), 1.47(\mathrm{~s}, 18 \mathrm{H}){ }^{13} \mathrm{C} \mathrm{NMR}\left(101 \mathrm{MHz}, \mathrm{CDCl}_{3}\right) \delta 167.30$, 152.01, 142.40, 135.50, 134.31, 133.38, 131.19, 130.87, 129.64, 129.18, 128.96, 128.16, 127.92, 127.25, 125.62, 121.17, 52.27, 34.81, 29.57, 17.43. Elemental analysis: Calcd for $\mathrm{C}_{46} \mathrm{H}_{46} \mathrm{O}_{6}$. C: 79.51, H, 6.67; Found: C, 79.54, H, 6.62. MALDI-TOF-MS: m/z 694.3306 (Calcd m/z 694.3294 for $\mathrm{M}^{+}$). 

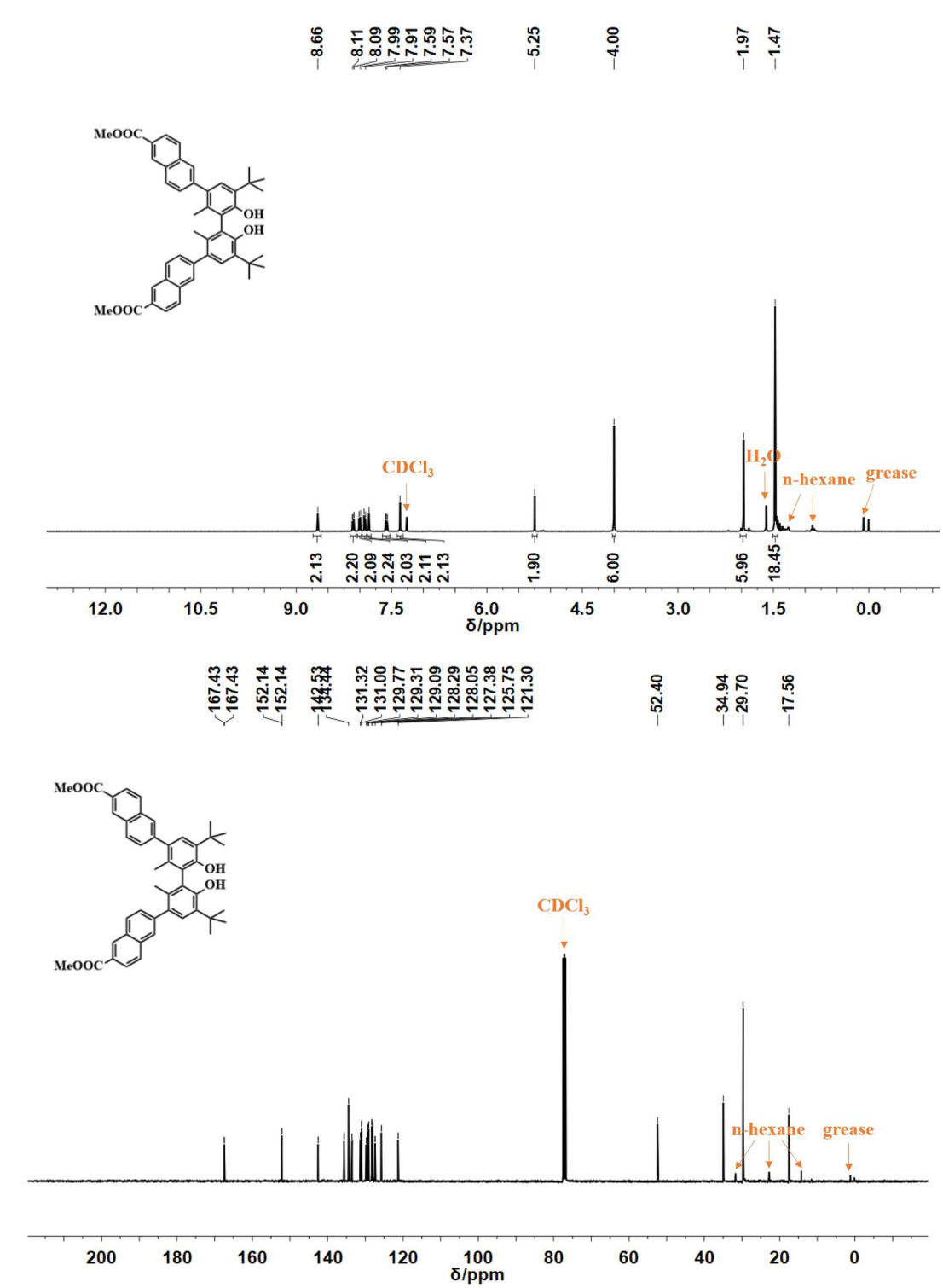

Synthesis of S2. S1 (1.1 g, $1.58 \mathrm{mmol})$ was charged into a two-neck flame-dried $250 \mathrm{~mL}$ flask and dissolved in $\mathrm{CH}_{2} \mathrm{Cl}_{2}(20 \mathrm{~mL})$. Anhydrous $\mathrm{AlCl}_{3}(2.5 \mathrm{~g}, 19 \mathrm{mmol})$ dissolved in nitromethane $(20 \mathrm{~mL})$ was added slowly at $0^{\circ} \mathrm{C}$. After that, the mixture was stirred at room temperature for $10 \mathrm{~h}$. $6 \mathrm{M} \mathrm{HCl}(20 \mathrm{~mL})$ was added and the mixture was stirred for $30 \mathrm{~min}$. The aqueous layer was extracted by $\mathrm{CH}_{2} \mathrm{Cl}_{2}$ and the combined organic layer was washed with brine, dried over $\mathrm{Na}_{2} \mathrm{SO}_{4}$ and then concentrated under reduced pressure. The crude product was dissolved in $\mathrm{CH}_{2} \mathrm{Cl}_{2}$ (30 $\mathrm{mL})$, and then morpholine $(0.83 \mathrm{~mL}, 9.50 \mathrm{mmol})$ and $\mathrm{I}_{2}(1.0 \mathrm{~g}, 3.95 \mathrm{mmol})$ were added at room temperature. The mixture was stirred for $10 \mathrm{~h}$. After that, $2 \mathrm{M} \mathrm{HCl}(15 \mathrm{~mL})$ was added. The aqueous layer was extracted with $\mathrm{CH}_{2} \mathrm{Cl}_{2}$, and the combined organic layer was washed with saturated $\mathrm{Na}_{2} \mathrm{~S}_{2} \mathrm{O}_{3}$ solution and brine, and then dried over $\mathrm{Na}_{2} \mathrm{SO}_{4}$ and concentrated under reduced pressure. The crude product was purified by column chromatography on silica gel $\left(\mathrm{CH}_{2} \mathrm{Cl}_{2} /\right.$ petroleum ether, $\left.1: 1, \mathrm{v} / \mathrm{v}, \mathrm{R}_{\mathrm{f}}=0.42\right)$ to afford $\mathbf{S 2}$ as a light-yellow solid $(0.98 \mathrm{~g}, 75 \%) .{ }^{1} \mathrm{H}$ NMR (500 MHz, CDCl $) \delta 8.63(\mathrm{~s}, 2 \mathrm{H}), 8.09(\mathrm{~d}, J=8.6 \mathrm{~Hz}, 2 \mathrm{H}), 7.96(\mathrm{~d}, J=8.5 \mathrm{~Hz}, 2 \mathrm{H}), 7.87(\mathrm{~d}$, $J=8.6 \mathrm{~Hz}, 2 \mathrm{H}), 7.78(\mathrm{~d}, J=11.2 \mathrm{~Hz}, 2 \mathrm{H}), 7.50(\mathrm{~d}, J=8.4 \mathrm{~Hz}, 2 \mathrm{H}), 5.72(\mathrm{~d}, J=4.9 \mathrm{~Hz}, 2 \mathrm{H}), 3.99$ (s, 6H), 1.99 (s, 6H). ${ }^{13} \mathrm{C}$ NMR $\left(126 \mathrm{MHz}, \mathrm{CDCl}_{3}\right) \delta 171.19,167.15,152.05,140.32,139.87$, $136.86,136.88,135.37,131.37,130.86,129.18,128.61,128.19,127.96,127.53,125.79,122.84$, 
81.77, 60.44, 52.34, 21.06, 17.81, 14.22. Elemental analysis: Calcd for $\mathrm{C}_{38} \mathrm{H}_{28} \mathrm{I}_{2} \mathrm{O}_{6}$. C: $54.70, \mathrm{H}$, 3.38; Found: C, 54.65, H, 3.42. MALDI-TOF-MS: m/z $833.9986\left(\right.$ Calcd m/z 833.9975 for $\mathrm{M}^{+}$).

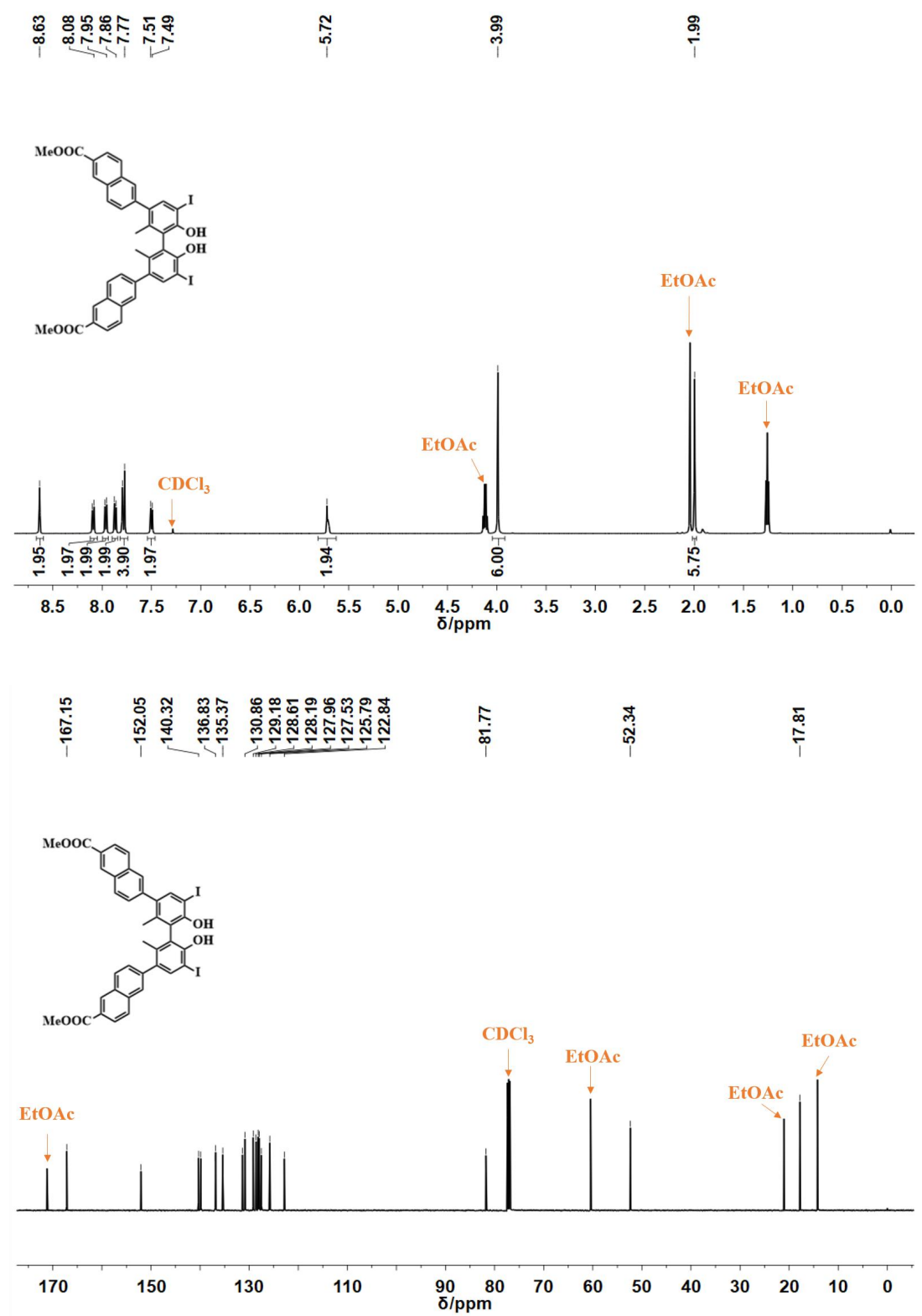

Synthesis of $(\boldsymbol{S})-\mathbf{M e}_{4} \mathbf{L}^{2}$. A $250 \mathrm{~mL}$ flame-dried round-bottom flask was charged with $\mathbf{S 2}(1.47 \mathrm{~g}$, $2.0 \mathrm{mmol})$, methyl 6-(4,4,5,5-tetramethyl-1,3,2-dioxaborolan-2-yl)-2-naphthoate (1.87 g, 6.0 mmol), $\mathrm{Pd}_{2}(\mathrm{dba})_{3}(275 \mathrm{mg}, 0.3 \mathrm{mmol})$, and $\mathrm{K}_{3} \mathrm{PO}_{4}(2.54 \mathrm{~g}, 12.0 \mathrm{mmol})$. The mixture was degassed and then $100 \mathrm{~mL}$ of degassed toluene/ethanol/water $(3: 1: 1, \mathrm{v} / \mathrm{v} / \mathrm{v})$ were added. The suspension was heated at $100{ }^{\circ} \mathrm{C}$ for $24 \mathrm{~h}$. After cooling to the r.t., the mixture was extracted by EtOAc. The combined organic extracts were dried over $\mathrm{Na}_{2} \mathrm{SO}_{4}$ and then concentrated under reduced pressure. The crude solid was purified by column chromatography on silica gel (EtOAc/petroleum ether, $\left.1: 10, \mathrm{v} / \mathrm{v}, \mathrm{R}_{\mathrm{f}}=0.25\right)$ to afford $(S)-\mathrm{Me}_{4} \mathbf{L}^{2}$ as a white solid $(1.24 \mathrm{~g}, 65 \%) .{ }^{1} \mathrm{H}$ NMR (400 MHz, $\left.\mathrm{CDCl}_{3}\right) \delta 8.65(\mathrm{~d}, J=12.4 \mathrm{~Hz}, 4 \mathrm{H}), 8.04(\mathrm{ddd}, J=58.1,42.9,17.4 \mathrm{~Hz}, 18 \mathrm{H}), 7.63(\mathrm{~d}, J=14.9 \mathrm{~Hz}$, 4H), 5.46 (s, 2H), 3.99 (d, $J=5.6 \mathrm{~Hz}, 12 \mathrm{H}), 2.20(\mathrm{~s}, 6 \mathrm{H}) .{ }^{13} \mathrm{C} \mathrm{NMR}\left(101 \mathrm{MHz}, \mathrm{CDCl}_{3}\right) \delta 171.18$, $167.20,150.53,141.50,137.54,136.20,135.63,135.57,135.49,132.98,131.58,131.33,130.89$, $130.80,129.39,129.17,128.93,128.40,128.33,128.18,128.05,127.93,127.42,126.11,125.75$, 
125.62, 122.64, 60.42, 52.25, 24.80, 21.03, 18.12, 14.21. Elemental analysis: Calcd for $\mathrm{C}_{62} \mathrm{H}_{46} \mathrm{O}_{10}$. C: 78.30, H, 4.88; Found: C, 78.27, H, 4.93. MALDI-TOF-MS: m/z 950.3138 (Calcd m/z 950.3091 for $\mathrm{M}^{+}$).
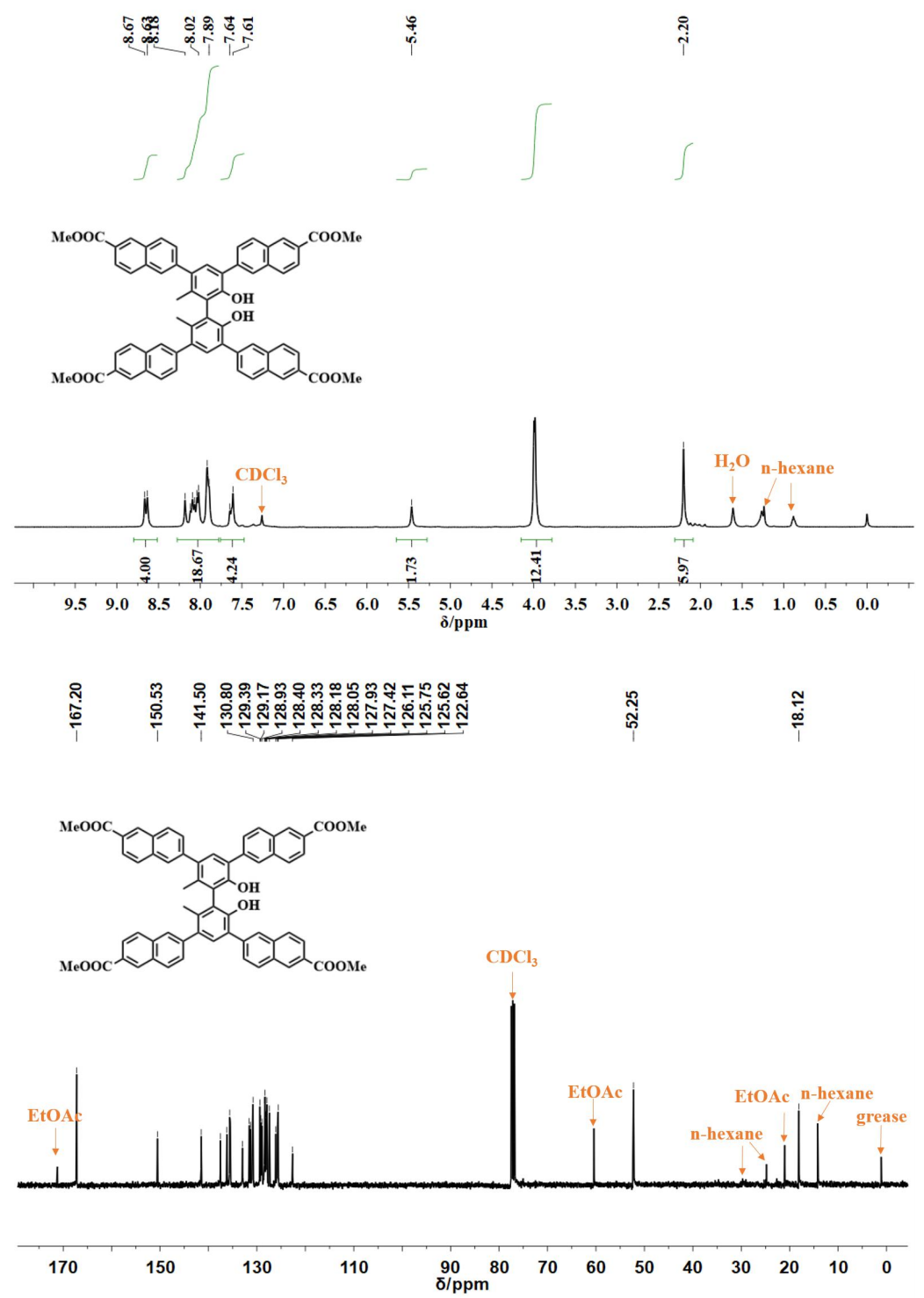

Synthesis of $(\boldsymbol{S})-\mathbf{H}_{4} \mathbf{L}^{2}$. A solution of $(S)-\mathrm{Me}_{4} \mathbf{L}^{2}(1.90 \mathrm{~g}, 2.0 \mathrm{mmol})$ and $\mathrm{LiOH} \cdot \mathrm{H}_{2} \mathrm{O}(1.68 \mathrm{~g}, 40$ mmol) in THF $(15 \mathrm{~mL}), \mathrm{MeOH}(45 \mathrm{~mL})$ and $\mathrm{H}_{2} \mathrm{O}(45 \mathrm{~mL})$ was heated at $75{ }^{\circ} \mathrm{C}$ for $6 \mathrm{~h}$. The solution was cooled to room temperature, acidified to $\mathrm{pH}=1-2$ with $6 \mathrm{M} \mathrm{HCl}$ and extracted with EtOAc. The organic phase was dried over $\mathrm{Na}_{2} \mathrm{SO}_{4}$ and the solvent was evaporated under reduced pressure to give a white solid of $(S)-\mathrm{H}_{4} \mathbf{L}^{2}$.(1.66 g, 93\%). ${ }^{1} \mathrm{H}$ NMR (500 MHz, DMSO- $\left.d^{6}\right) \delta 13.08$ $(\mathrm{s}, 1 \mathrm{H}), 8.66(\mathrm{~d}, J=11.4 \mathrm{~Hz}, 4 \mathrm{H}), 8.40(\mathrm{~s}, 2 \mathrm{H}), 8.28(\mathrm{~s}, 2 \mathrm{H}), 8.18(\mathrm{t}, J=8.5 \mathrm{~Hz}, 4 \mathrm{H}), 8.13-7.91(\mathrm{~m}$, $10 \mathrm{H}), 7.75(\mathrm{~d}, J=8.3 \mathrm{~Hz}, 2 \mathrm{H}), 7.47(\mathrm{~s}, 2 \mathrm{H}), 2.09(\mathrm{~s}, 6 \mathrm{H}) \cdot{ }^{13} \mathrm{C}$ NMR $\left(126 \mathrm{MHz}, \mathrm{DMSO}-d^{6}\right) \delta$ $167.98,151.96,142.30,139.37,135.74,135.64,135.51,134.10,132.06,131.49,130.79,130.67$, $130.16,129.64,129.37,129.19,128.78,128.71,128.32,128.24,128.13,127.93,126.84,126.63$, 126.35, 125.93, 125.74, 18.56. Elemental analysis: Calcd for $\mathrm{C}_{58} \mathrm{H}_{38} \mathrm{O}_{10}$. C: 77.84, H, 4.28; Found: C, 77.80, H, 4.25. ESI-MS: m/z 893.2387 (Calcd m/z 893.2414 for $\left[\mathrm{H}_{4} \mathbf{L}^{2}-\mathrm{H}\right]^{-}$). 

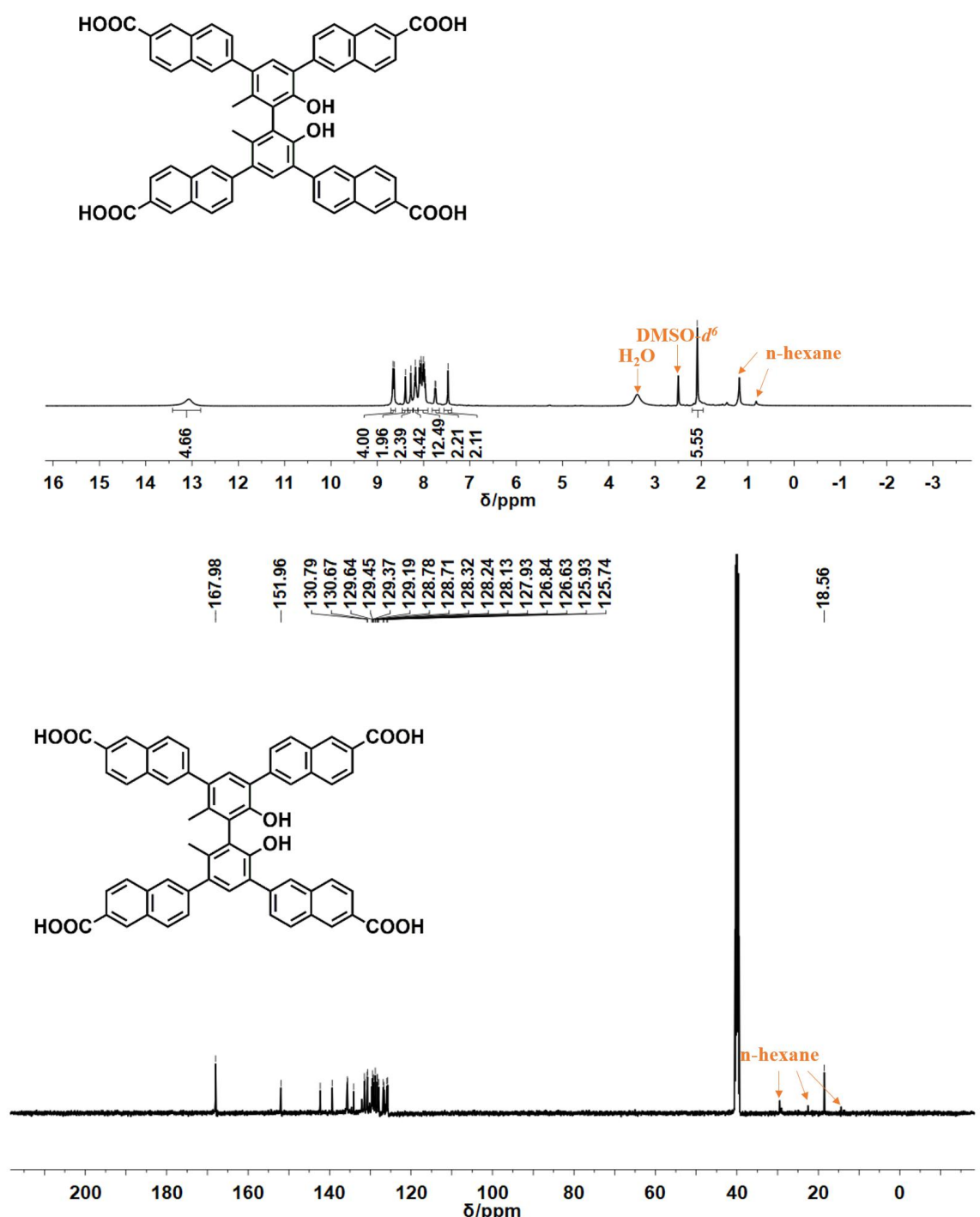

\subsection{Synthesis of $\mathbf{H}_{4} \mathrm{~L}^{3}$}

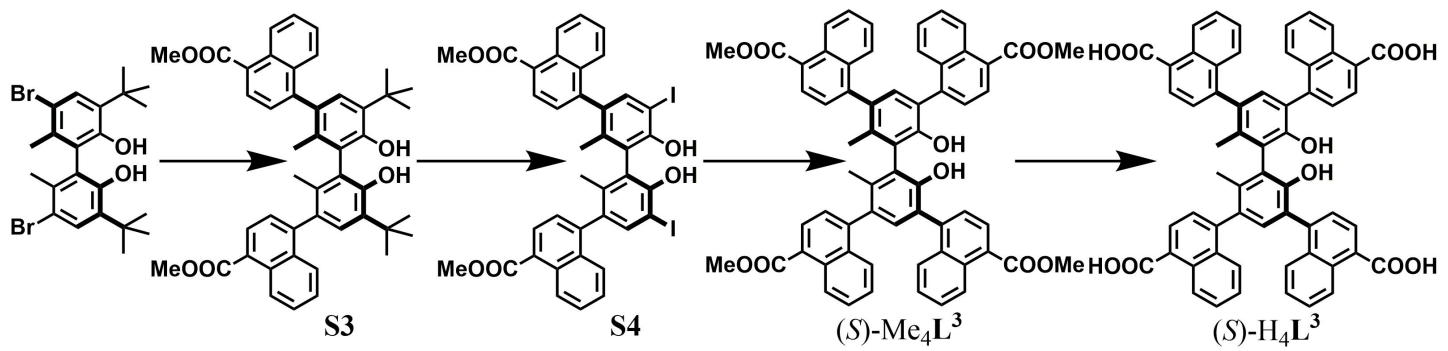

Synthesis of S3. A $250 \mathrm{~mL}$ flame-dried round-bottom flask was charged with 6,6'-dimethyl-3,3'-di-tert-butyl-5,5'-dibromolbiphenyl-2,2'-diol (4.8 g, $10 \mathrm{mmol})$, methyl

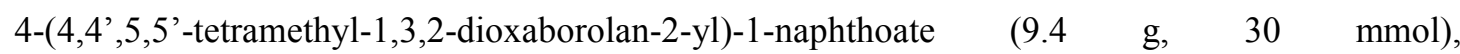
$\operatorname{Pd}(\mathrm{dppf}) \mathrm{Cl}_{2} \cdot \mathrm{CH}_{2} \mathrm{Cl}_{2}(244.5 \mathrm{mg}, 0.3 \mathrm{mmol})$, and $\mathrm{K}_{2} \mathrm{CO}_{3}(13.8 \mathrm{~g}, 100 \mathrm{mmol})$. The mixture was degassed for three times, and then degassed mixture solvents of $45 \mathrm{~mL} \mathrm{DME} / \mathrm{H}_{2} \mathrm{O}(\mathrm{v} / \mathrm{v}=2 / 1)$ were 
added. After cooling to room temperature, the resulting mixture was extracted with $\mathrm{CH}_{2} \mathrm{Cl}_{2}$. The combined organic extracts were washed with water, dried over $\mathrm{Na}_{2} \mathrm{SO}_{4}$ and then concentrated under reduced pressure. The crude solid was purified by column chromatography on silica gel $\left(\mathrm{CH}_{2} \mathrm{Cl}_{2} /\right.$ petroleum ether, 8:1, v/v, $\left.\mathrm{R}_{\mathrm{f}}=0.32\right)$ to afford $\mathbf{S 3}$ as a white solid $(5.28 \mathrm{~g}, 76 \%) .{ }^{1} \mathrm{H}$ NMR $\left(500 \mathrm{MHz}, \mathrm{CDCl}_{3}\right) \delta$ 9.02-8.97 (m, 2H), 8.29-8,21 (m, 2H), 7.66-7.33 (m, 8H), 7.27-7.24 (m, 2H), $5.31(\mathrm{dd}, J=26.0,4.2 \mathrm{~Hz}, 2 \mathrm{H}), 4.08-3.98(\mathrm{~m}, 6 \mathrm{H}), 1.76-1.61(\mathrm{~m}, 6 \mathrm{H}), 1.49-1.38(\mathrm{~m}, 18 \mathrm{H}) .{ }^{13} \mathrm{C}$ NMR $\left(126 \mathrm{MHz}, \mathrm{CDCl}_{3}\right) \delta 167.95,152.91,151.99,151.95,151.93,145.27,145.20,134.37$, $134.35,134.32$, 134.07, 134.05, 134.01, 133.99, 132.80, 132.79, 132.75, 132.73, 132.27, 132.23, $132.21,131.46,131.44,131.40,129.54,129.49,129.38,127.39,127.35,126.44,126.39,126.31$, $126.26,126.23,126.21,126.18,126.02,125.95,125.88,120.51,120.45,120.40,120.35,52.08$, 34.67, 29.46, 16.92, 16.90. Elemental analysis: Calcd for $\mathrm{C}_{46} \mathrm{H}_{46} \mathrm{O}_{6}$. C: 79.51, H, 6.67; Found: C, 79.48, H, 6.73. MALDI-TOF-MS: m/z 694.3306 (Calcd m/z 694.3294 for $\mathrm{M}^{+}$).

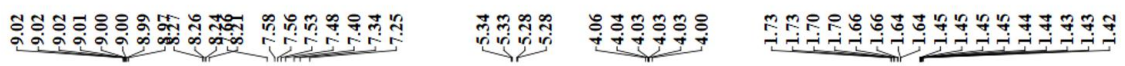

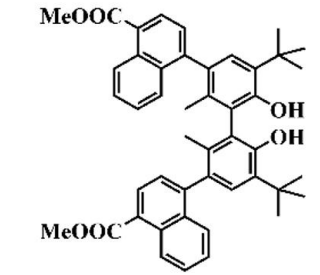

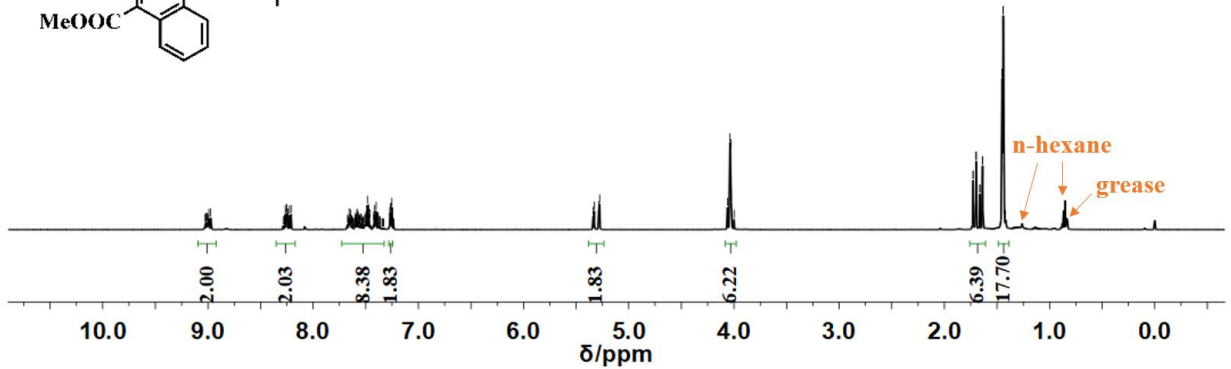

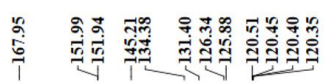

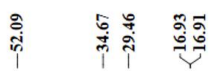
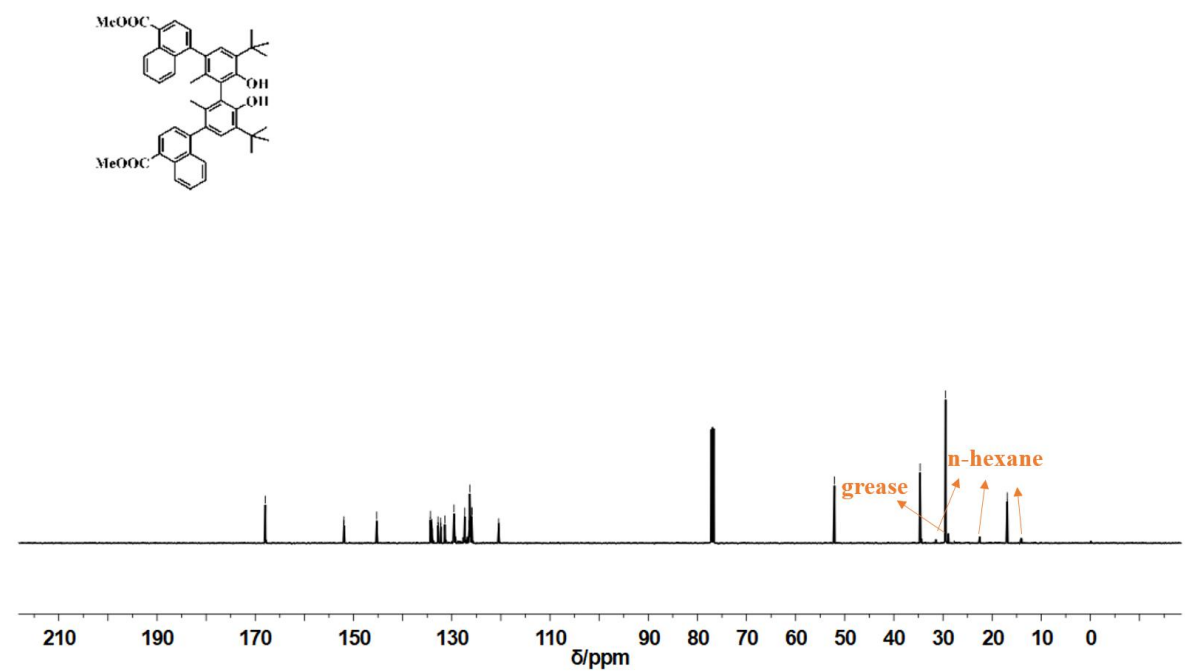
Synthesis of $\mathbf{S 4}$. S3 (1.38 g, $2 \mathrm{mmol})$ was charged into a two-neck flame-dried $250 \mathrm{~mL}$ flask and dissolved in $\mathrm{CH}_{2} \mathrm{Cl}_{2}(30 \mathrm{~mL})$. Anhydrous $\mathrm{AlCl}_{3}(3.20 \mathrm{~g}, 24 \mathrm{mmol})$ dissolved in nitromethane $(30 \mathrm{~mL})$ was added slowly at $0{ }^{\circ} \mathrm{C}$. After the addition was completed, the reaction was stirred at room temperature for $10 \mathrm{~h}$. Then, $6 \mathrm{M} \mathrm{HCl}(30 \mathrm{~mL})$ was added. The mixture was stirred for 30 min, and extracted by $\mathrm{CH}_{2} \mathrm{Cl}_{2}$. The combined organic layer was washed with brine, dried over $\mathrm{Na}_{2} \mathrm{SO}_{4}$ and then concentrated under reduced pressure. The crude product was dissolved in $\mathrm{CH}_{2} \mathrm{Cl}_{2}$ $(40 \mathrm{~mL})$, then morpholine $(1.04 \mathrm{~mL}, 12 \mathrm{mmol})$ and $\mathrm{I}_{2}(1.27 \mathrm{~g}, 5 \mathrm{mmol})$ were added at room temperature. The mixture was stirred for $10 \mathrm{~h}$. After that, $2 \mathrm{M} \mathrm{HCl}(20 \mathrm{~mL})$ was added. The aqueous layer was extracted with $\mathrm{CH}_{2} \mathrm{Cl}_{2}$, and the combined organic layer was washed saturated $\mathrm{Na}_{2} \mathrm{~S}_{2} \mathrm{O}_{3}$ solution and brine, and then dried over $\mathrm{Na}_{2} \mathrm{SO}_{4}$ and concentrated under reduced pressure. The crude product was purified by column chromatography on silica gel $\left(\mathrm{CH}_{2} \mathrm{Cl}_{2}\right.$ /petroleum ether, $\left.1: 1, \mathrm{v} / \mathrm{v}, \mathrm{R}_{\mathrm{f}}=0.45\right)$ to afford $\mathbf{S} 4$ as a yellow solid $(1.38 \mathrm{~g}, 83 \%) .{ }^{1} \mathrm{H}$ NMR $\left(400 \mathrm{MHz}, \mathrm{CDCl}_{3}\right) \delta$ 9.00-8.97 (m, 2H), 8.27-8.20 (m, 2H), 7.69-7.37 (m, 10H), 5.42 (dd, $J=16.6,5.9 \mathrm{~Hz}, 2 \mathrm{H}), 4.04$ (s, $6 \mathrm{H}), 1.73(\mathrm{dd}, J=24.1,3.7 \mathrm{~Hz}, 6 \mathrm{H}) .{ }^{13} \mathrm{C} \mathrm{NMR}\left(126 \mathrm{MHz}, \mathrm{CDCl}_{3}\right) \delta 168.02,167.97,152.11$, $152.03,151.95,143.22,143.09,139.60,139.49,139.34,138.12,138.06,134.92,132.57,131.49$, $129.64,129.53,127.78,127.69,127.06,126.81,126.71,126.43,126.25,126.17,126.03,122.65$, $122.54,122.41,81.91,81.84,81.79,81.71,52.35,17.41$. Elemental analysis: Calcd for $\mathrm{C}_{38} \mathrm{H}_{28} \mathrm{I}_{2} \mathrm{O}_{6}$. C: 54.70, H, 3.38; Found: C, 54.67, H, 3.42. MALDI-TOF-MS: m/z 834.0060 (Calcd m/z 833.9975 for $\mathrm{M}^{+}$).
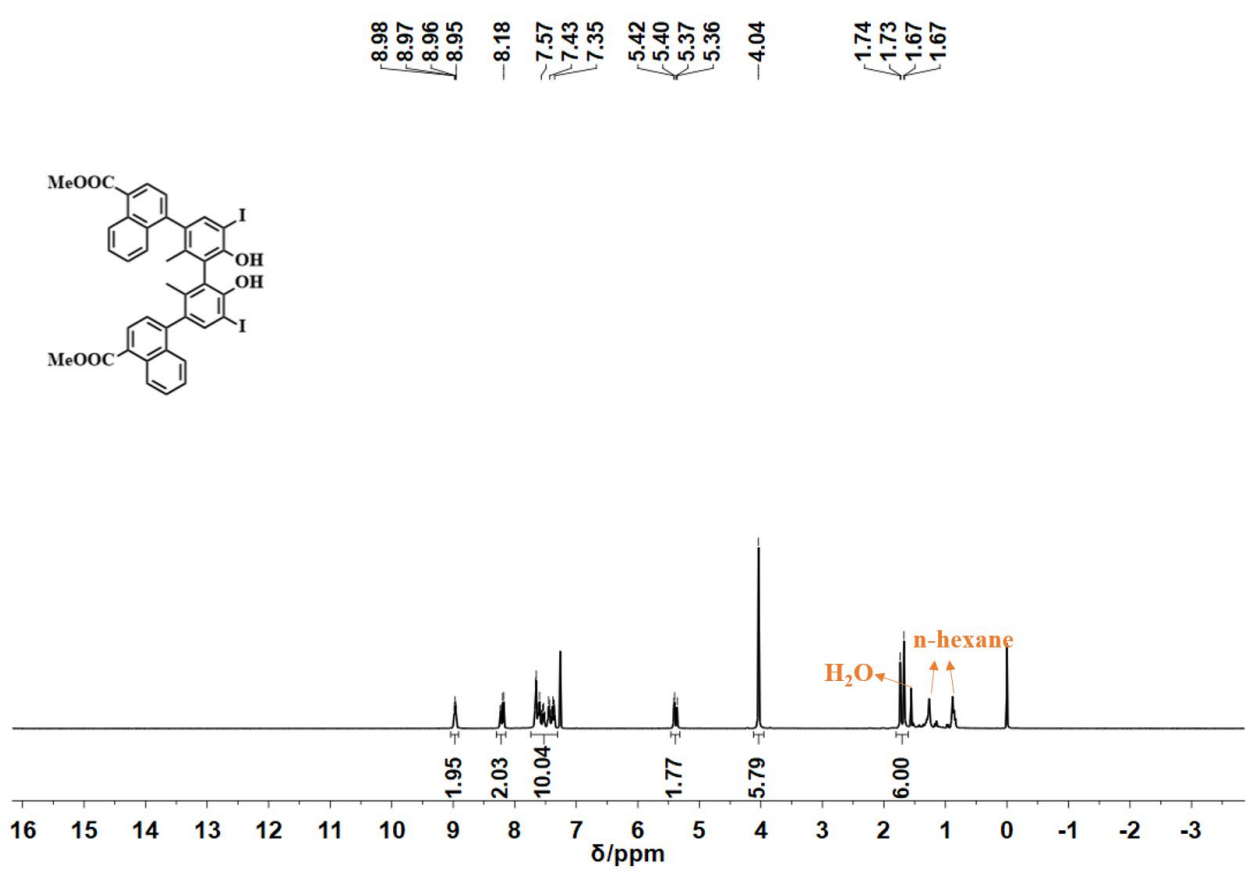


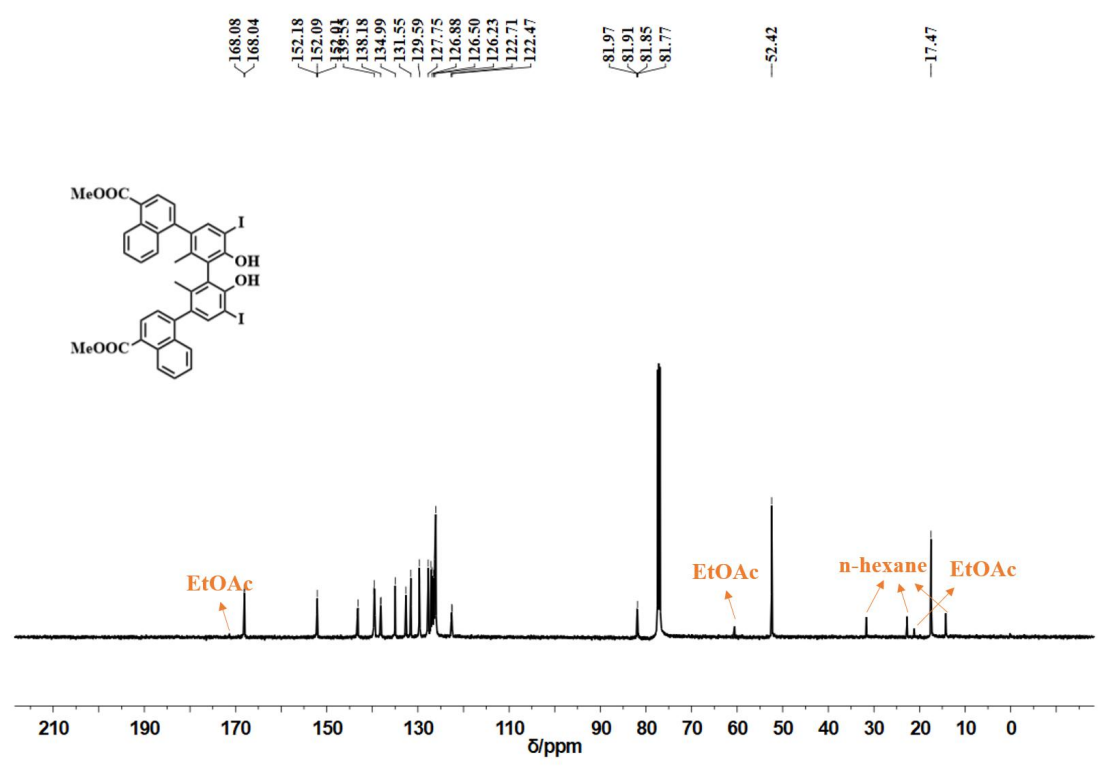

Synthesis of $(\boldsymbol{S})-\mathbf{M e}_{4} \mathbf{L}^{3}$. A $250 \mathrm{ml}$ flame-dried round-bottom flask was charged with $\mathbf{S 4}(1.47 \mathrm{~g}$, $2.0 \mathrm{mmol})$, methyl 4-(4,4',5,5'-tetramethyl-1,3,2-dioxaborolan-2-yl)-1-naphthoate (1.87 g, 6.0 $\mathrm{mmol}), \mathrm{Pd}_{2}(\mathrm{dba})_{3}(275 \mathrm{mg}, 0.3 \mathrm{mmol})$, and $\mathrm{K}_{3} \mathrm{PO}_{4}(2.54 \mathrm{~g}, 12.0 \mathrm{mmol})$, Then a mixed solution $(100 \mathrm{~mL})$ with toluene/ethanol/water $(3: 1: 1, \mathrm{v} / \mathrm{v} / \mathrm{v})$ degassed three times was added. The suspension was heated at $100{ }^{\circ} \mathrm{C}$ for $24 \mathrm{~h}$. The combined organic extracts were dried over $\mathrm{Na}_{2} \mathrm{SO}_{4}$ and then concentrated under reduced pressure. The crude solid was purified by column chromatography on silica gel (EtOAc/petroleum ether, 1:10, v/v, $\mathrm{R}_{\mathrm{f}}=0.23$ ) to afford $(S)-\mathrm{Me}_{4} \mathbf{L}^{3}$ as a white solid (1.33 g, $1.4 \mathrm{mmol}, 70 \%) .{ }^{1} \mathrm{H}$ NMR $\left(500 \mathrm{MHz}, \mathrm{CDCl}_{3}\right) \delta$ 9.01-8.98 (m, 4H), 8.26-8.23 (m, 4H), 7.72-7.45 (m, 16H), 7.35-7.31 (m, 2H), $4.03(\mathrm{~m}, 12 \mathrm{H}), 2.07(\mathrm{t}, J=11.0 \mathrm{~Hz}$, $6 \mathrm{H}) .{ }^{13} \mathrm{C}$ NMR $\left(126 \mathrm{MHz}, \mathrm{CDCl}_{3}\right) \delta 175.63,168.18,168.15,168.04,168.03,168.01,167.97$, $150.57,144.58,144.51,144.33,143.64,140.27,140.13,140.03,137.84,137.71,133.25,133.10$, $132.99,132.91,132.81,132.33,132.29,132.20,132.12,131.69,131.64,130.59,129.84,129.76$, $127.93,127.88,127.58,127.47,127.11,126.89,126.86,126.74,126.52,126.34,126.27,126.25$, $125.25,125.59,124.64,124.45,124.28,122.62,122.45,75.24,52.38,24.89$. Elemental analysis: Calcd for $\mathrm{C}_{62} \mathrm{H}_{46} \mathrm{O}_{10}$. C: 78.30, H, 4.88; Found: C, 78.34, H, 4.83. MALDI-TOF-MS: $\mathrm{m} / \mathrm{z}$ $950.3068\left(\right.$ Calcd m/z 950.3091 for $\left.\mathrm{M}^{+}\right)$.

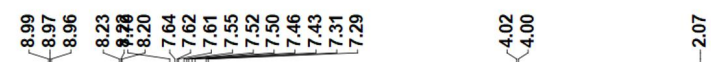
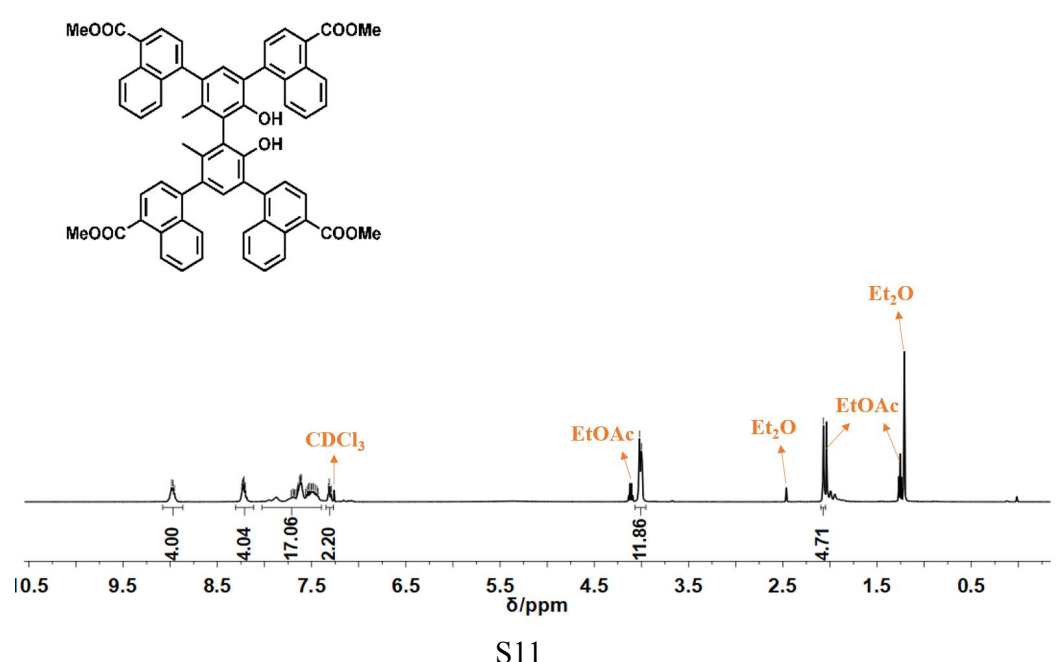


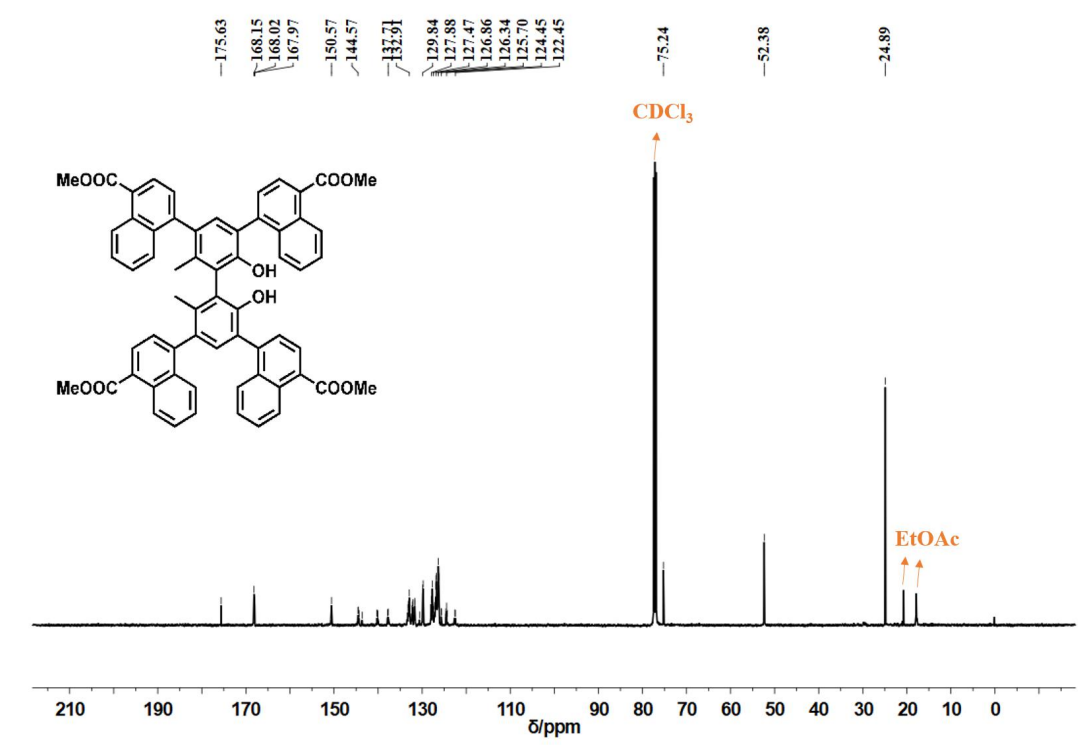

Synthesis of $(\boldsymbol{S})-\mathbf{H}_{4} \mathbf{L}^{3}$. A solution of $(S)-\mathrm{Me}_{4} \mathbf{L}^{3}(1.90 \mathrm{~g}, 2.0 \mathrm{mmol})$, and $\mathrm{LiOH} \cdot \mathrm{H}_{2} \mathrm{O}(1.68 \mathrm{~g}, 40$ mmol) in THF $(15 \mathrm{~mL}), \mathrm{MeOH}(45 \mathrm{~mL})$ and $\mathrm{H}_{2} \mathrm{O}(45 \mathrm{~mL})$ was heated at $75{ }^{\circ} \mathrm{C}$ for $6 \mathrm{~h}$. The solution was cooling to room temperature, acidified to $\mathrm{pH}=1 \sim 2$ with $6 \mathrm{M} \mathrm{HCl}$ and extracted with EtOAc. The organic phase was dried over $\mathrm{Na}_{2} \mathrm{SO}_{4}$ and the solvent was evaporated under reduced pressure to give a white solid of $(S)-\mathrm{H}_{4} \mathbf{L}^{3}(1.60 \mathrm{~g}, 89 \%) .{ }^{1} \mathrm{H}$ NMR $(400 \mathrm{MHz}, \mathrm{DMSO}) \delta 13.14$ (s, 1H), $8.94(\mathrm{~s}, 4 \mathrm{H}), 8.22(\mathrm{~m}, 8 \mathrm{H}), 7.63(\mathrm{~m}, 15 \mathrm{H}), 7.08$ (ddd, $J=27.5,16.1,13.5 \mathrm{~Hz}, 2 \mathrm{H}), 1.86(\mathrm{~m}$, 1H). ${ }^{13} \mathrm{C}$ NMR (101 MHz, DMSO- $\left.d^{6}\right) \delta 169.52,169.44,152.70,145.11,142.58,136.91,133.07$, 132.38, 132.31, 131.68, 130.08, 127.94, 127.47, 126.93, 126.69, 126.46, 125.82, 125.58, 125.40, 18.21. Elemental analysis: Calcd for $\mathrm{C}_{58} \mathrm{H}_{38} \mathrm{O}_{10}$. C: 77.84, H, 4.28; Found: C, 77.79, H, 4.26. ESI-MS: m/z $893.2411\left(\right.$ Calcd m/z 893.2387 for $\left.\left[\mathrm{H}_{4} \mathbf{L}^{3}-\mathrm{H}\right]^{-}\right)$.

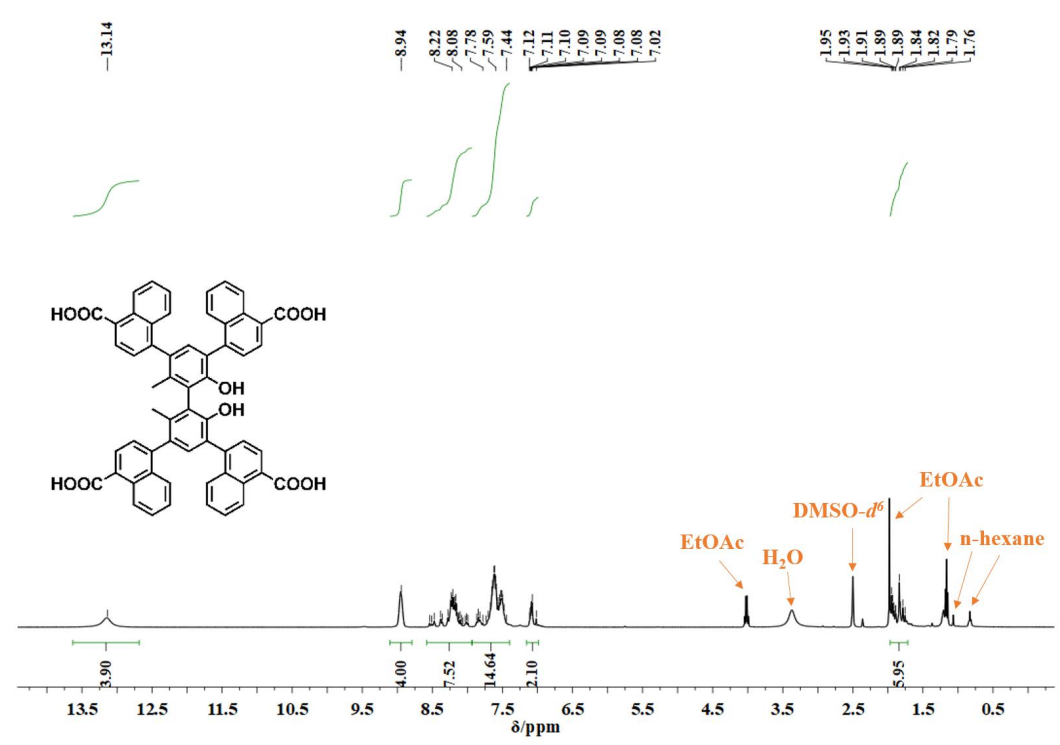




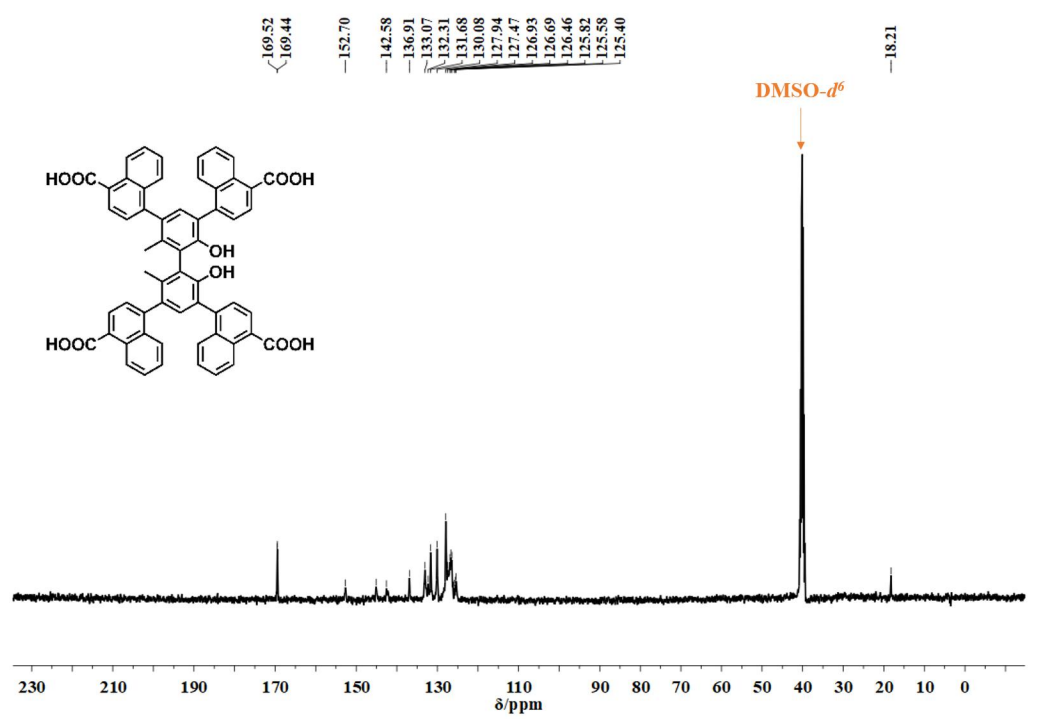

\subsection{Synthesis of MOFs}

Synthesis of $1^{\text {flu }}$ : A mixture of $\mathrm{ZrOCl}_{2} \cdot 8 \mathrm{H}_{2} \mathrm{O}(38.7 \mathrm{mg}, 0.12 \mathrm{mmol}), \mathrm{H}_{4} \mathbf{L}^{1}(20.8 \mathrm{mg}, 0.03 \mathrm{mmol})$, DMF $(3 \mathrm{~mL})$, TFA $(1.5 \mathrm{~mL})$ was sealed in a $20 \mathrm{~mL}$ vial with a screw cap and heated at $120{ }^{\circ} \mathrm{C}$ for $24 \mathrm{~h}$. Colorless polyhedral crystals were collected, washed with DMF and acetone and dried in air. Yield: $57 \mathrm{mg}, 86 \%$. FT-IR (KBr, cm $\left.{ }^{-1}\right): 3408(\mathrm{~s}), 2960(\mathrm{w}), 2866(\mathrm{w}), 1693(\mathrm{w}), 1600(\mathrm{~s}), 1538(\mathrm{~m})$, 1409(s), 1311(w), 1283(w), 1261(w), 1239(w), 1180(m), 1104(m), 1018(m), 863(w), 792(m), 755(w), 714(m), 651(s), 562(w), 471(m). Elemental analysis: Calcd for $\mathrm{C}_{84} \mathrm{H}_{68} \mathrm{O}_{36} \mathrm{Zr}_{6}$. C: 45.84, H, 3.11; Found: C, 46.32, H, 2.92.

Synthesis of $\mathbf{1}^{\text {ith }}$ : A mixture of $\mathrm{ZrOCl}_{2} \cdot 8 \mathrm{H}_{2} \mathrm{O}(38.7 \mathrm{mg}, 0.12 \mathrm{mmol}), \mathrm{H}_{4} \mathbf{L}^{1}(20.8 \mathrm{mg}, 0.03 \mathrm{mmol})$, DMF $(3 \mathrm{~mL}), \mathrm{HOAc}(2 \mathrm{~mL})$ was sealed in a $20 \mathrm{~mL}$ vial with a screw cap and heated at $120^{\circ} \mathrm{C}$ for $24 \mathrm{~h}$. Colorless rod-like crystals were collected, washed with DMF and acetone and dried in air. Yield: $82 \mathrm{mg}, 84 \%$. FT-IR (KBr, cm$\left.{ }^{-1}\right)$ : 3427(s), 2930(w), 2868(w), 1658(s), 1604(s), 1554(w), 1490(m), 1404(s), 1386(s), 1252(w), 1224(w), 1180(m), 1146(w), 1097(s), 1059(w), 1034(w), 920(w), 892(w), 865(w), 823(m), 782(m), 769(m), 725(w), 662(s), 483(m). Elemental analysis: Calcd for $\mathrm{C}_{126} \mathrm{H}_{96} \mathrm{O}_{51} \mathrm{Zr}_{9}$. C: 46.61, H, 2.98; Found: C, 45.93, H, 3.02.

Synthesis of $2^{\text {flu }}$ : A mixture of $\mathrm{ZrOCl}_{2} \cdot 8 \mathrm{H}_{2} \mathrm{O}(38.7 \mathrm{mg}, 0.12 \mathrm{mmol}), \mathrm{H}_{4} \mathbf{L}^{2}(26.8 \mathrm{mg}, 0.03 \mathrm{mmol})$, DMF $(3 \mathrm{~mL})$, TFA $(1.3 \mathrm{~mL})$ was sealed in a $10 \mathrm{~mL}$ vial with a screw cap and heated at $120{ }^{\circ} \mathrm{C}$ for $24 \mathrm{~h}$. Colorless polyhedral crystals were collected, washed with DMF and acetone and dried in air. Yield: 64 mg, 82\%. FT-IR (KBr, cm-1): 3382(s), 2924(w), 1653(s), 1630(w), 1606(w), 1584(w), 1552(w), 1486(m), 1416(s), 1384(m), 1249(w), 1201(s), 1147(m), 1100(w), 1029(w), 962(w), 919(m), 893(m), 851(w), 819(m), 779(m), 760(m), 726(m), 661(s), 525(w), 503(w), 478(m). Elemental analysis: Calcd for $\mathrm{C}_{116} \mathrm{H}_{84} \mathrm{O}_{36} \mathrm{Zr}_{6}$. C: 53.56, H, 3.26; Found: C, 54.60, H, 3.32 .

Synthesis of $2^{\text {ith. }}$ A mixture of $\mathrm{ZrOCl}_{2} \cdot 8 \mathrm{H}_{2} \mathrm{O}(38.7 \mathrm{mg}, 0.12 \mathrm{mmol}), \mathrm{H}_{4} \mathbf{L}^{2}(26.8 \mathrm{mg}, 0.03 \mathrm{mmol})$, DMF $(3 \mathrm{~mL}), \mathrm{HOAc}(2 \mathrm{~mL})$ was sealed in a $20 \mathrm{~mL}$ vial with a screw cap and heated at $120^{\circ} \mathrm{C}$ for $24 \mathrm{~h}$. Colorless polyhedral crystals were collected, washed with DMF and acetone and dried in air. Yield: 96 mg, 78\%. FT-IR (KBr, cm $\left.{ }^{-1}\right)$ : 3420(s), 2960(w), 2930(m), 2866(w), 1660(s), 1608(w), 1588(w), 1559(w), 1490(m), 1454(w), 1438(w), 1417(s), 1388(s), 1292(m), 1253(m), 1226(m), 1183(m), 1153(w), 1135(w), 1099(s), 1062(m), 1035(w), 963(w), 920(m), 892(m), 866(w), 823(s), 781(m), 762(m), 726(w), 662(s), 642(w), 482(m). Elemental analysis: Calcd for $\mathrm{C}_{174} \mathrm{H}_{120} \mathrm{O}_{50} \mathrm{Zr}_{12}$. C: 50.91, H, 2.95; Found: C, 51.60, H, 3.06. 
Synthesis of $3^{\text {ith }}$ : A mixture of $\mathrm{ZrOCl}_{2} \cdot 8 \mathrm{H}_{2} \mathrm{O}(38.7 \mathrm{mg}, 0.12 \mathrm{mmol}), \mathrm{H}_{4} \mathbf{L}^{\mathbf{3}}(26.8 \mathrm{mg}, 0.03 \mathrm{mmol})$, DMF $(2 \mathrm{~mL})$, TFA $(1 \mathrm{~mL})$ was sealed in a $15 \mathrm{~mL}$ vial with a screw cap and heated at $120{ }^{\circ} \mathrm{C}$ for 24 h. Colorless polyhedral crystals were collected, washed with DMF and acetone and dried in air. Yield: $98 \mathrm{mg}, 85 \%$. FT-IR (KBr, cm$\left.{ }^{-1}\right):$ 3403(s), 2923(w), 2853(w), 1656(s), 1615(w), 1593(s), 1559(w), 1512(s), 1467(m), 1423(s), 1372(s), 1266(m), 1239(w), 1185(w), 1151(m), 1100(m), 1060(m), 1032(w), 1013(w), 967(w), 917(w), 861(m), 803(s), 783(s), 663(s), 646(s), 541(w), 507(w), 469(w). Elemental analysis: Calcd for $\mathrm{C}_{174} \mathrm{H}_{120} \mathrm{O}_{51} \mathrm{Zr}_{9}$. C: 54.31, H, 3.14; Found: C, 55.11, $\mathrm{H}, 3.23$.

\section{General procedure for catalysis}

\subsection{Synthesis of $(S)-\mathrm{Me}_{4} \mathrm{~L}^{1}-\mathrm{P}-\mathrm{Ir}$}

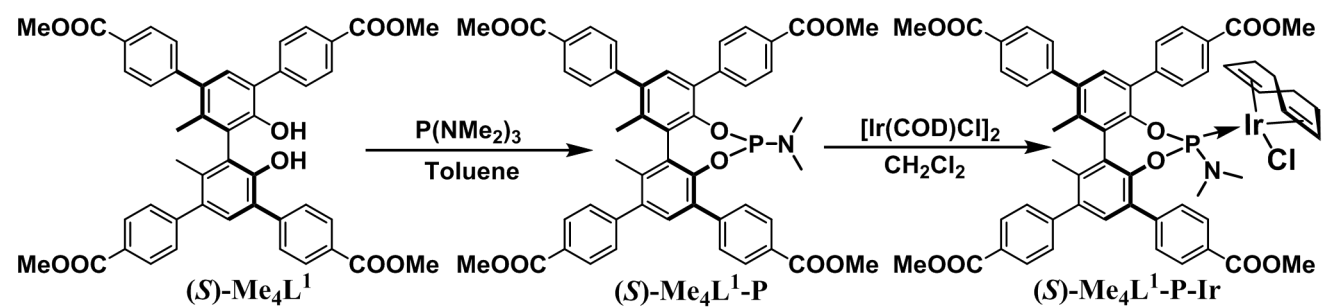

To a solution of $\mathrm{P}\left(\mathrm{NMe}_{2}\right)_{3}(489.6 \mathrm{mg}, 3 \mathrm{mmol})$ in anhydrous toluene $(2 \mathrm{~mL}),(S)-\mathrm{Me}_{4} \mathbf{L}^{1}(751$ $\mathrm{mg}, 1 \mathrm{mmol})$ in anhydrous toluene $(5 \mathrm{~mL})$ was added. The reaction flask was heated to reflux and maintained at this temperature for $12 \mathrm{~h}$ under nitrogen. The reaction mixture was cooled to room temperature. Solvent was removed under reduced pressure and the crude product was purified by flash chromatography (EtOAc/petroleum ether, 1:8, $\mathrm{v} / \mathrm{v}, \mathrm{R}_{\mathrm{f}}=0.21$ ) to give light yellow solid (750 mg, 91\%). ${ }^{1} \mathrm{H}$ NMR $\left(400 \mathrm{MHz}, \mathrm{CDCl}_{3}\right) \delta 8.12-8.05(\mathrm{~m}, 1 \mathrm{H}), 7.77(\mathrm{~d}, J=8.1 \mathrm{~Hz}, 2 \mathrm{H}), 7.68(\mathrm{~d}, J=$ $8.0 \mathrm{~Hz}, 2 \mathrm{H}), 7.47$ (s, 4H), 7.35 (d, $J=15.6 \mathrm{~Hz}, 2 \mathrm{H}), 3.94-3.90(\mathrm{~m}, 12 \mathrm{H}), 2.17$ (d, $J=21.4 \mathrm{~Hz}, 6 \mathrm{H})$, $1.99(\mathrm{~d}, J=9.1 \mathrm{~Hz}, 6 \mathrm{H}) .{ }^{13} \mathrm{C}$ NMR $\left(101 \mathrm{MHz}, \mathrm{CDCl}_{3}\right) \delta 167.24,167.15,167.11,147.74,147.25$, $146.55,146.47,142.56,142.42,138.92,138.62,136.41,136.14,132.18,131.88,131.54,131.31$, $130.69,130.55,129.86,129.78,129.67,129.60,129.20,129.08,128.86,52.40,52.34,52.30$, 34.78, 34.58, 29.91, 18.96. ${ }^{31} \mathrm{P}$ NMR (162 MHz, $\left.\mathrm{CDCl}_{3}\right) \delta$ 141.61. ESI-MS: m/z 824.2645 (Calcd $\mathrm{m} / \mathrm{z} 824.2625$ for $\left.[\mathrm{M}+\mathrm{H}]^{+}\right)$.

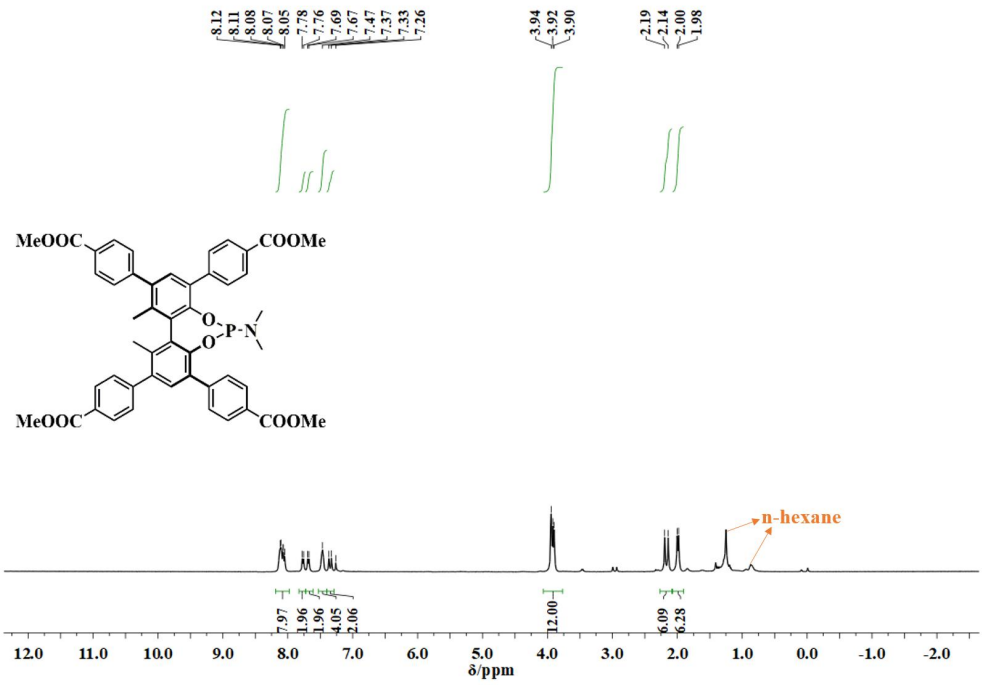




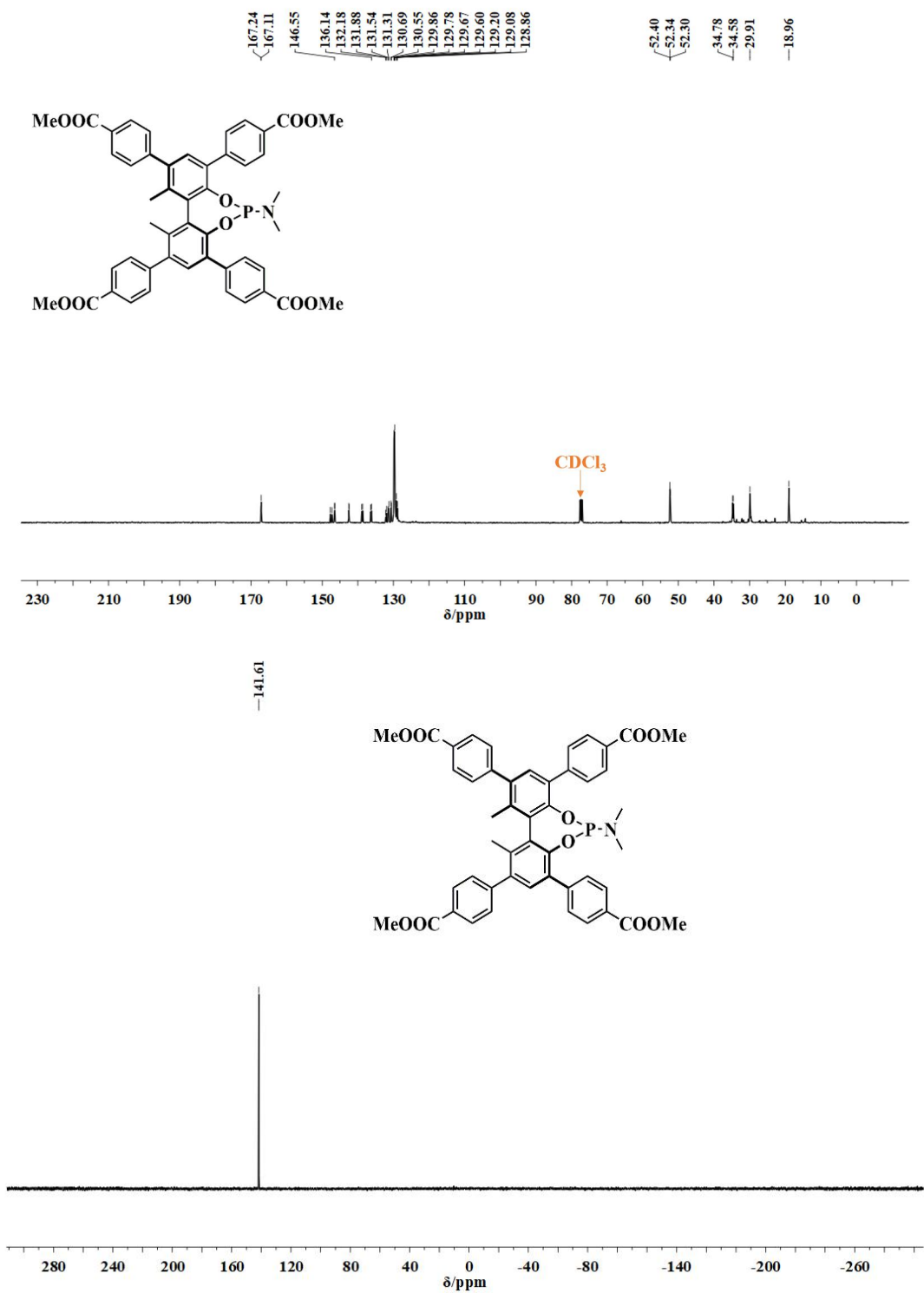

$[\operatorname{Ir}(\mathrm{COD}) \mathrm{Cl}]_{2}(101 \mathrm{mg}, 0.15 \mathrm{mmol})$ and $(S)-\mathrm{Me}_{4} \mathbf{L}^{1}-\mathbf{P}(249 \mathrm{mg}, 0.3 \mathrm{mmol})$ were dissolved in $\mathrm{CH}_{2} \mathrm{Cl}_{2}(1.0 \mathrm{~mL})$, and the mixture was stirred at room temperature under nitrogen for $30 \mathrm{~min}$. The solvent was removed in vacuo to afford $(S)-\mathrm{Me}_{4} \mathbf{L}^{1}$-P-Ir as an orange solid (327 mg, 94\%). X-ray quality crystals of $\mathrm{Me}_{4} \mathrm{~L}^{1}$-P-Ir were obtained by slowly evaporation from $\mathrm{CH}_{2} \mathrm{Cl}_{2} /$ hexane mixture. ${ }^{1} \mathrm{H}$ NMR $\left(400 \mathrm{MHz}, \mathrm{CDCl}_{3}\right) \delta$ 8.15-8.04 (m, 8H), $7.72(\mathrm{dd}, J=49.4,8.0 \mathrm{~Hz}, 4 \mathrm{H}), 7.47-7.38(\mathrm{~m}$, $6 \mathrm{H}), 5.13(\mathrm{~s}, 1 \mathrm{H}), 4.93(\mathrm{~s}, 1 \mathrm{H}), 3.88(\mathrm{~d}, J=37.4 \mathrm{~Hz}, 12 \mathrm{H}), 3.29(\mathrm{~s}, 1 \mathrm{H}), 2.48(\mathrm{~s}, 1 \mathrm{H}), 2.20-2.13(\mathrm{~m}$, 12H). ${ }^{13} \mathrm{C}$ NMR $\left(101 \mathrm{MHz}, \mathrm{CDCl}_{3}\right) \delta 167.23,167.00,166.94,146.77,146.66,146.39,146.24$, $146.00,141.72,141.47,139.65,136.58,135.99,132.71,131.42,131.18,130.96,130.73,129.93$, $129.68,129.60,129.44,129.37,104.89,104.71,103.04,102.85,53.08,52.44,52.10,36.88,36.78$, $34.71,33.25,32.12,31.66,29.73,29.33,28.56,25.41,25.09,22.89,18.81,14.34 .{ }^{31} \mathrm{P}$ NMR $(162$ $\left.\mathrm{MHz}, \mathrm{CDCl}_{3}\right) \delta$ 111.50. ESI-MS: m/z $1165.3380\left(\mathrm{Calcd} \mathrm{m} / \mathrm{z} 1165.3380\right.$ for $\left.[\mathrm{M}-\mathrm{Cl}+\mathrm{MeCN}]^{+}\right)$. 


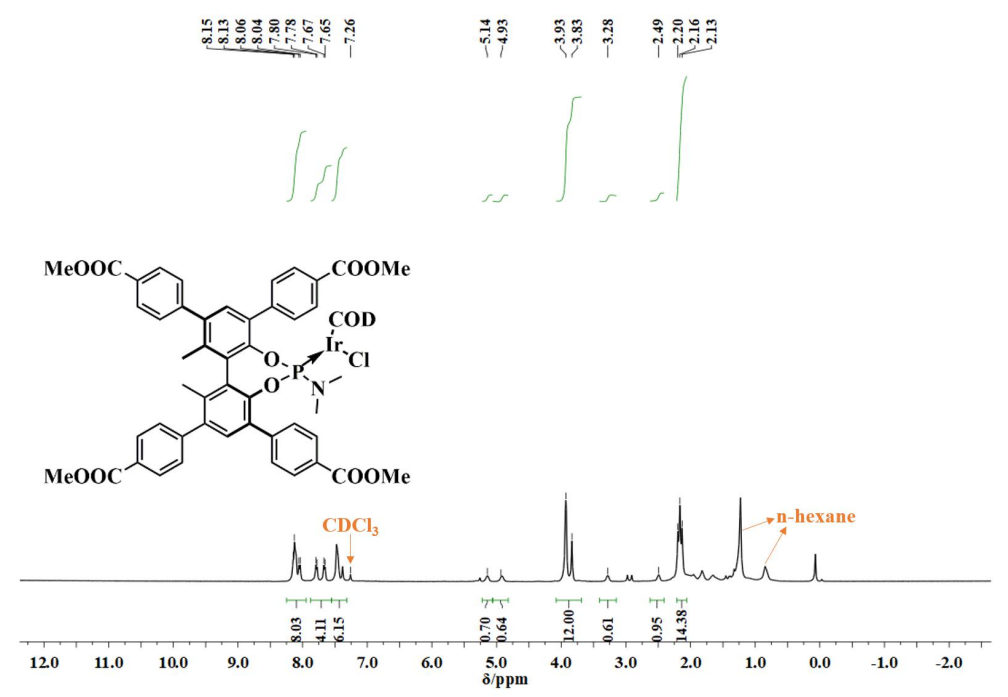

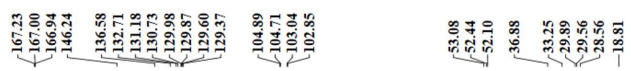
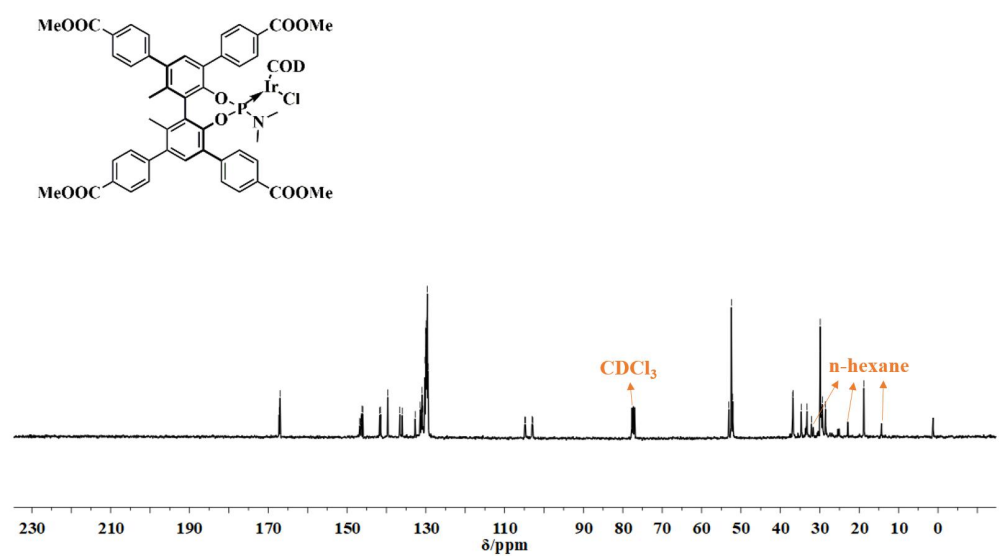

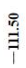
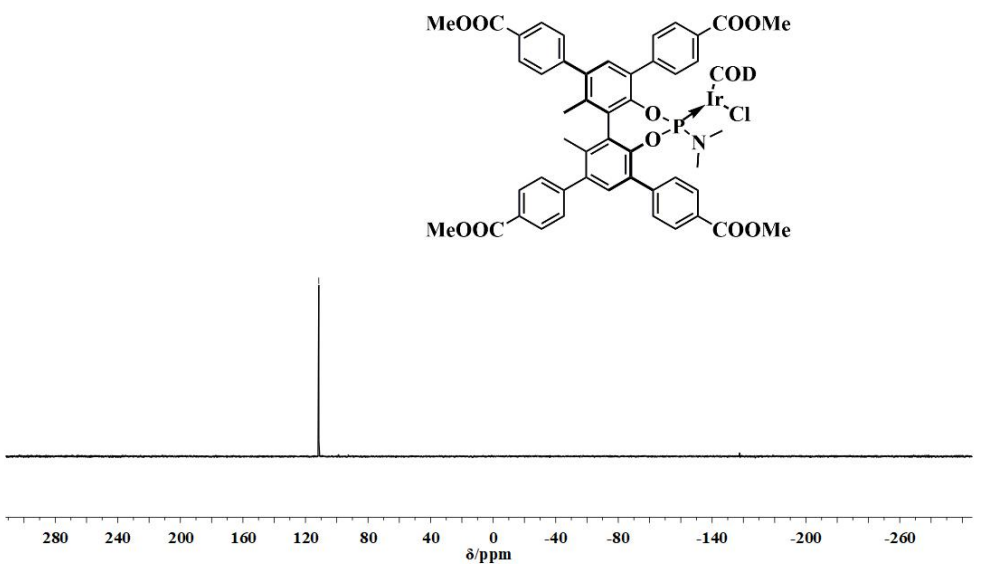

\subsection{Synthesis of $1^{\text {flu }}-\mathrm{P}-\mathrm{Ir}$ and $2^{\text {flu }}$-P-Ir}

Freshly prepared $1^{\text {flu }}(0.1 \mathrm{mmol})$ was weighted into a sealed tube in a nitrogen-filed glovebox. After addition of $\mathrm{P}\left(\mathrm{NMe}_{2}\right)_{3}(49 \mathrm{mg}, 0.3 \mathrm{mmol})$ and toluene $(5 \mathrm{~mL})$, the mixture was stirred overnight. The light orange solid of $\mathbf{1}^{\text {flu-}} \mathbf{P}$ was centrifuged out of suspension and washed with 
toluene to remove the unreacted $\mathrm{P}\left(\mathrm{NMe}_{2}\right)_{3}$. Then, the solid was washed with $\mathrm{CH}_{2} \mathrm{Cl}_{2}$ for several times to remove the toluene and was dried at $80{ }^{\circ} \mathrm{C}$ under vacuum. Solid ${ }^{31} \mathrm{P}$ NMR: $138.29 \mathrm{ppm}$. $\mathbf{1}^{\text {flu_}} \mathbf{P}(0.1 \mathrm{mmol})$ was weighted into a sealed tube in a nitrogen-filed glovebox. After addition of [ $\operatorname{Ir}(\mathrm{COD}) \mathrm{Cl}]_{2}(134 \mathrm{mg}, 0.2 \mathrm{mmol})$ and dried $\mathrm{CH}_{2} \mathrm{Cl}_{2}(5 \mathrm{~mL})$, the mixture was stirred overnight.

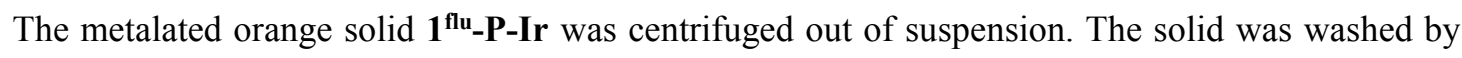
dried $\mathrm{CH}_{2} \mathrm{Cl}_{2}$ until the washing solution became colorless. Moreover, ICP-MS analysis indicated that the Ir content in washing solution was $<0.05 \%$. Solid ${ }^{31} \mathrm{P}$ NMR: $108.10 \mathrm{ppm}$. ICP-MS analysis revealed that the Ir loading was $5.5 \mathrm{wt} \%$, and the $\mathrm{Zr} / \mathrm{P} / \mathrm{Ir}$ ratio was about $6 / 0.84 / 0.72$. Thus, the molecular formula was $\mathrm{Zr}_{6} \mathrm{O}_{4}(\mathrm{OH})_{4}\left(\mathrm{H}_{2} \mathrm{O}\right)_{4}\left(\mathbf{L}^{1}\right)_{1.16}\left(\mathbf{L}^{\mathbf{1}}-\mathbf{P N M e}\right)_{0.84}(\operatorname{Ir}(\mathrm{COD}) \mathrm{Cl})_{0.72}$ for $1^{\text {flu-P-Ir. }}$

$2^{\text {flu }}$-P-Ir was synthesized in a similar procedure. Solid ${ }^{31}$ P NMR: $108.31 \mathrm{ppm}$. ICP-MS analysis revealed that the Ir loading was $5.3 \mathrm{wt} \%$, and the $\mathrm{Zr} / \mathrm{P} / \mathrm{Ir}$ ratio was about $6 / 0.90 / 0.80$. Thus, the molecular formula was $\mathrm{Zr}_{6} \mathrm{O}_{4}(\mathrm{OH})_{4}\left(\mathrm{H}_{2} \mathrm{O}\right)_{4}\left(\mathbf{L}^{2}\right)_{1.1}\left(\mathbf{L}^{2}-\mathbf{P N M e}\right)_{0.9}(\operatorname{Ir}(\mathrm{COD}) \mathrm{Cl})_{0.8}$ for $\mathbf{2}^{\text {flu }}-\mathbf{P}-\mathbf{I r}$.

\subsection{Synthesis of the substrates}

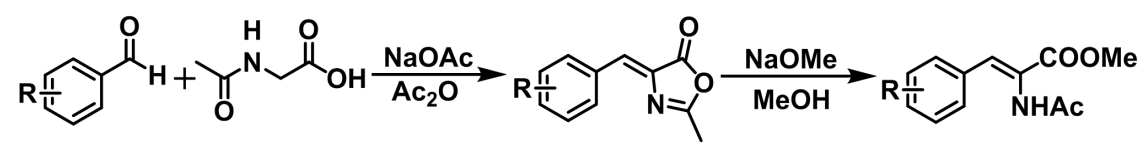

The $\alpha$-amino acid derivatives were synthesized according to a reported procedure. ${ }^{2,3}$

Briefly, the aromatic aldehyde $(20.0 \mathrm{mmol}), \mathrm{NaOAc}(10.0 \mathrm{mmol})$ and $\mathrm{N}$-acetylglycine $(16$ mmol) were suspended in $\mathrm{Ac}_{2} \mathrm{O}(50 \mathrm{mmol})$. The reaction mixture was stirred at $140{ }^{\circ} \mathrm{C}$ for $3 \mathrm{~h}$. The resulting crude product was washed with ice water $(100 \mathrm{~mL})$ in three portions. The resulting solid was dried in vacuo at $60{ }^{\circ} \mathrm{C}$ for entire removal of residual water. The crude product was suspended in $\mathrm{MeOH}(20 \mathrm{~mL})$ and heated to reflux. After $2 \mathrm{~h}$, the reaction mixture was slowly cooled to r.t. The azlactone was separated and used for subsequent synthetic steps without further purification.

The azlactone $(10.0 \mathrm{mmol})$ was suspended in anhydrous $\mathrm{MeOH}(10 \mathrm{~mL})$ and $\mathrm{NaOMe}(540 \mathrm{mg}$, $10.00 \mathrm{mmol}$ ) was added. The reaction mixture was stirred for $5 \mathrm{~h}$ at r.t. The solvent was evaporated in vacuo and the residue was diluted with DCM $(50 \mathrm{~mL})$. The organic phase was washed with sat. aq. $\mathrm{NH}_{4} \mathrm{Cl}$ solution and brine, dried over $\mathrm{Na}_{2} \mathrm{SO}_{4}$, concentrated and dried in vacuo. The crude product was dissolved in a small amount of EtOAc and precipitated with hexanes.

\subsection{Asymmetric catalytic hydrogenation reaction}

A glass vial was charged with substrate $(0.2 \mathrm{mmol})$ and catalyst $(0.5 \mathrm{~mol} \% \mathrm{Ir})$. Dry $\mathrm{CH}_{2} \mathrm{Cl}_{2}(2$ $\mathrm{mL}$ ) was added. The vial was placed into a high-pressure hydrogenation apparatus. The reactor was purged three times with $\mathrm{H}_{2}$, then filled with 5 bar $\mathrm{H}_{2}$. The reaction was performed at room temperature. After the reaction was completed, the $\mathrm{H}_{2}$ pressure was released carefully and the solvent was removed in vacuo. The crude product was filtered through on a short plug of silica. The ee values of the products were determined by HPLC.

Gram-scale hydrogenation reaction of $\mathbf{4 a}$. To a glass tube was charged substrate $\mathbf{4 a}(1.1 \mathrm{~g}, 5.0$

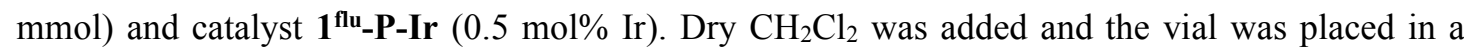


high-pressure hydrogenation apparatus. The reactor was purged three times with $\mathrm{H}_{2}$, and then filled with 5 bar $\mathrm{H}_{2}$. The reaction was stirred at room temperature for 24 hours before the $\mathrm{H}_{2}$ pressure was released and the solvent was removed in vacuo. The crude product was purified by flash chromatography to afford the product as a white solid (1.06 g, 96\% yield). The ee value was determined by HPLC.

\subsection{Recycling experiment}

To a glass tube was added substrate $(Z)$-methyl- $\alpha$-acetamidocinnamate $(1 \mathrm{mmol}), \mathbf{1}^{\mathrm{flu}}$-P-Ir $(0.5$

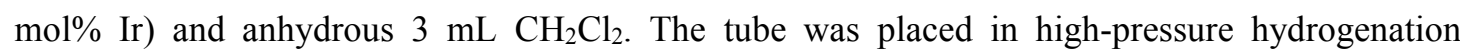
apparatus. The reactor was purged three times with $\mathrm{H}_{2}$, and then filled with 5 bar $\mathrm{H}_{2}$. After the reaction was completed, the catalyst was separated by centrifugation, and the supernatant was concentrated and purified by flash chromatography to give the desired product. The recovered $1^{\text {flu-}}$-P-Ir was washed by dry $\mathrm{CH}_{2} \mathrm{Cl}_{2}$, reactivated at $80^{\circ} \mathrm{C}$ for $2 \mathrm{~h}$ and then used for the next runs.

\subsection{Asymmetric cyanation reaction}

To a stirred suspension of evacuated $\mathbf{1}^{\text {ith }}(0.01 \mathrm{mmol})$ in $5 \mathrm{~mL}$ of wet-toluene (including 0.003 mmol $\mathrm{H}_{2} \mathrm{O}$ in $5 \mathrm{~mL}$ toluene) was added dropwise n-BuLi (1.6 $\mathrm{M}$ in hexane, $0.02 \mathrm{mmol}$ ) at r.t under $\mathrm{N}_{2}$ atmosphere, and the mixture was stirred for $30 \mathrm{~min}$. p-methoxylbenzaldehyde $(2.0 \mathrm{mmol})$ was added, and the mixture was stirred for $30 \mathrm{~min}$ at r.t. This mixture was cooled to $-78{ }^{\circ} \mathrm{C}$ and then stirred for $10 \mathrm{~min}$ at that temperature. Trimethylsilylcyanide (Caution! $2.0 \mathrm{mmol}$ ) was added dropwise. After stirring for $6 \mathrm{~h}$ the reaction mixture was centrifuged at 14,000 rpm for $10 \mathrm{~min}$ and the supernatant was diluted with $10 \mathrm{w} / \mathrm{w} \% \mathrm{HCl} / \mathrm{MeOH}(1 \mathrm{~mL})$ at $-78{ }^{\circ} \mathrm{C}$. The filtrate was extracted with ethyl acetate $(10 \mathrm{~mL} \times 2)$ and washed with brine $(10 \mathrm{~mL})$, dried over $\mathrm{MgSO}_{4}$ and evaporated under reduced pressure to give the cyanohydrin. To a solution of the crude cyanohydrin in $\mathrm{CH}_{2} \mathrm{Cl}_{2}(2 \mathrm{~mL})$ were added pyridine $(0.16 \mathrm{~mL}, 2 \mathrm{mmol})$ and acetic anhydride $(0.14$ $\mathrm{mL}, 1.5 \mathrm{mmol})$ at $-78{ }^{\circ} \mathrm{C}$. The mixture was stirred at room temperature for $30 \mathrm{~min}$, diluted with ethyl acetate $(20 \mathrm{~mL})$ and $1 \mathrm{M} \mathrm{HCl}(10 \mathrm{~mL})$. The organic phase was separated, washed with water $(10 \mathrm{~mL})$, sat. $\mathrm{NaHCO}_{3}$ solution $(10 \mathrm{~mL})$ and brine $(10 \mathrm{~mL})$, dried over $\mathrm{MgSO}_{4}$ and evaporated under reduced pressure. The crude cyanohydrin acetate was purified by neutral silica gel column chromatography (hexane/EtOAc $=10 / 1$ ) to afford the desired products. The ee value of the product was determined by HPLC.

\section{Table S1. Dye inclusion experiments}

Fresh MOFs $(10 \mu \mathrm{mol})$ were soaked in a saturated solution of methyl orange (MO, $60 \mathrm{mg})$ in water for $24 \mathrm{~h}$, respectively. The resulting orange crystals were washed with water thoroughly until the washings become colorless. The washed samples were digested by saturated KF solution, the resultant clear solutions were diluted to $1000 \mathrm{~mL}$. Absorption experiments were performed on a PerkinElmer Lambda $35 \mathrm{UV} /$ Vis Spectrometer. The amount of dyes was determined by comparing the UV absorption with a standard curve.

Creation of a standard curve:

$$
A=\log _{10} \frac{I_{0}}{I_{t}}=\log _{10} \frac{1}{T}=k \cdot l \cdot c
$$


MO: (1) 20, 12, 6, 3, 1.5, and $0.75 \mu \mathrm{M}$ MO solutions were prepared, respectively. (2) The absorbance of different concentrations of MO was determined by UV/Vis spectrometer. Data for known concentrations of MO were used to make the standard curve, plotting concentration on the $\mathrm{X}$ axis, and the assay measurement of absorbance on the $\mathrm{Y}$ axis. According to the Beer-Lambert law, the standard curve can be calculated by linear fitting of the data.

The absorbance of the sample solutions were determined by the UV/Vis spectrometer. The concentrations of dye can be calculated by comparing the UV-Vis absorbance with a standard curve.
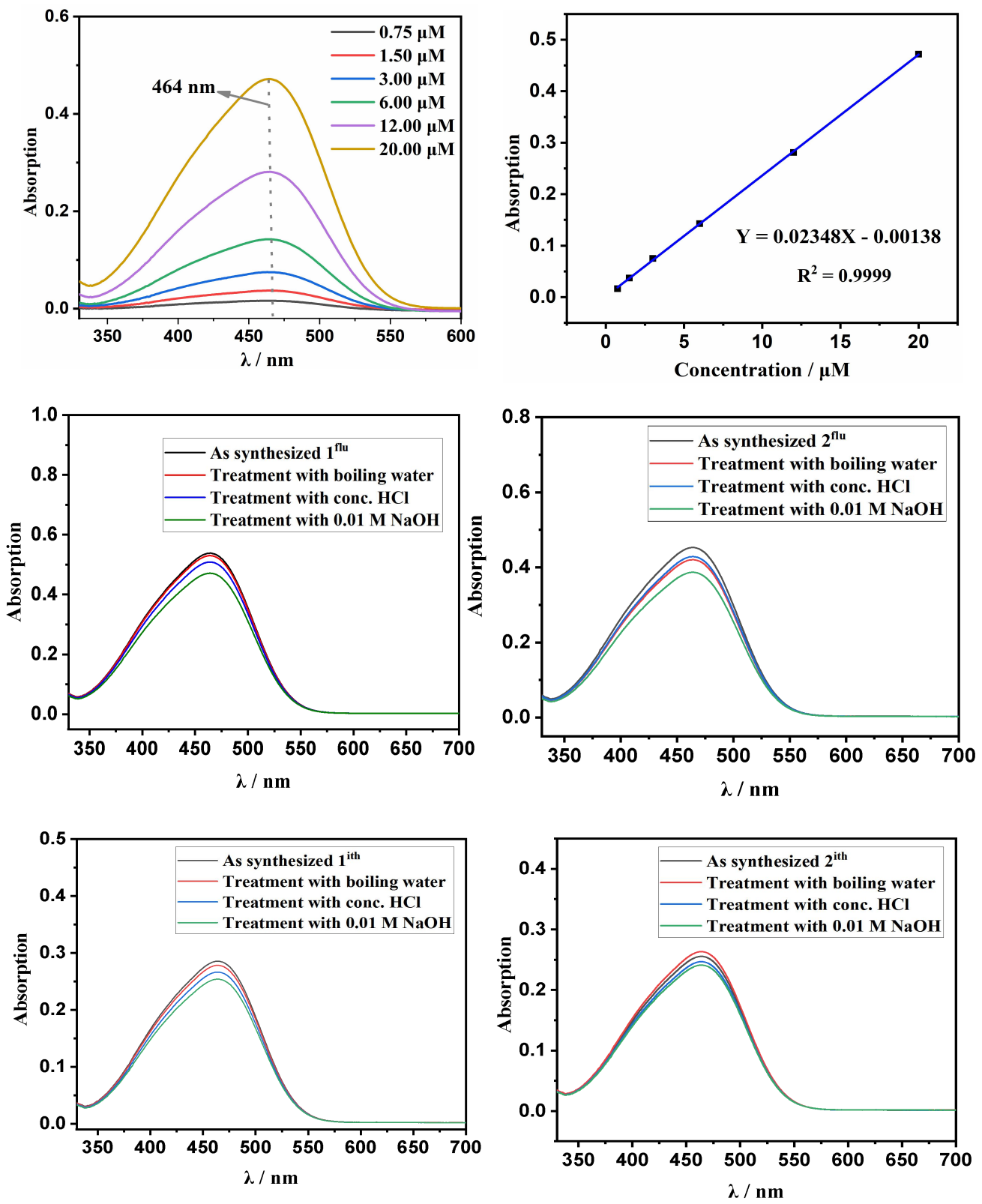


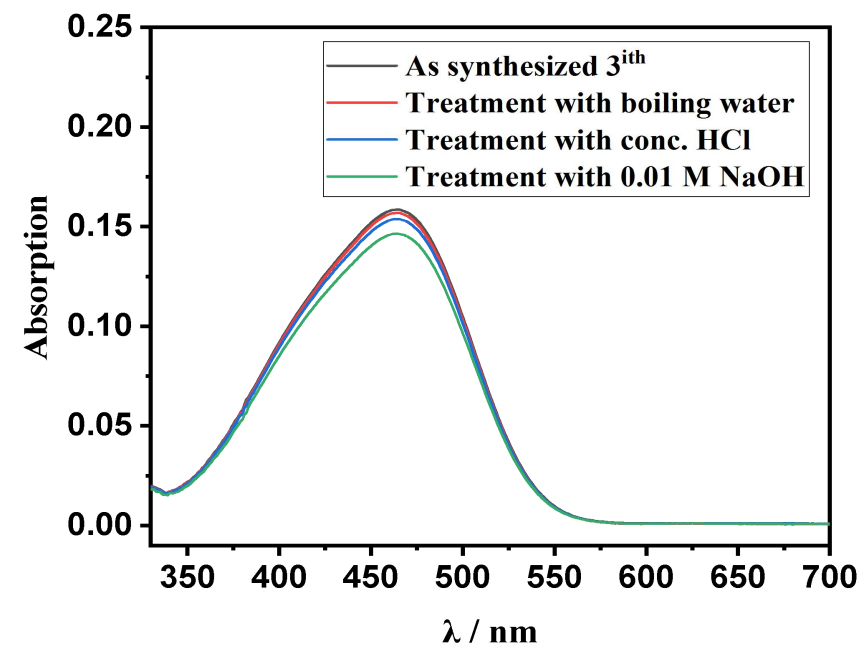

Table S1 Dye adsorption results

\begin{tabular}{|c|c|c|c|c|c|}
\hline & $\mathbf{1}^{\text {flu }}$ & $\mathbf{2}^{\text {flu }}$ & $\mathbf{1}^{\text {ith }}$ & $\mathbf{2}^{\text {ith }}$ & $\mathbf{3}^{\text {ith }}$ \\
\hline Pristine & 5.6 & 6.2 & 5.0 & 5.6 & 3.2 \\
\hline Boiling water & 5.5 & 5.8 & 4.9 & 5.8 & 3.2 \\
\hline Conc. $\mathrm{HCl}$ & 5.3 & 5.9 & 4.7 & 5.4 & 3.1 \\
\hline $0.01 \mathrm{M} \mathrm{NaOH}$ & 4.9 & 5.3 & 4.7 & 5.3 & 3.0 \\
\hline
\end{tabular}

5. Figure S1. TGA curves

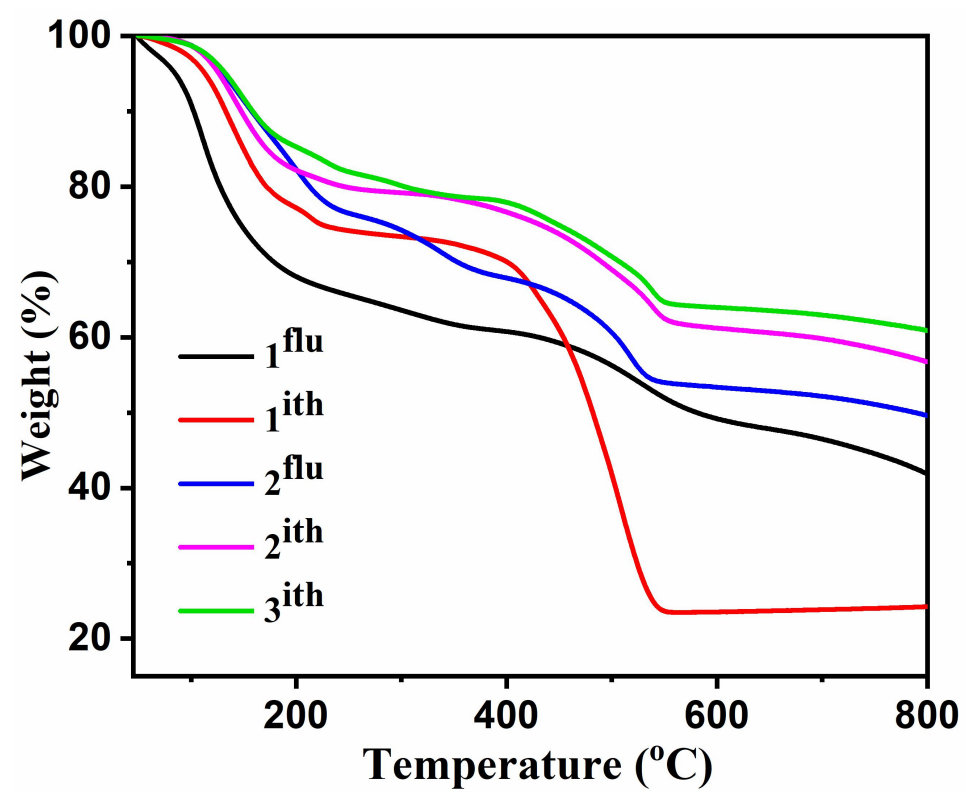




\section{Figure S2. CD spectra}
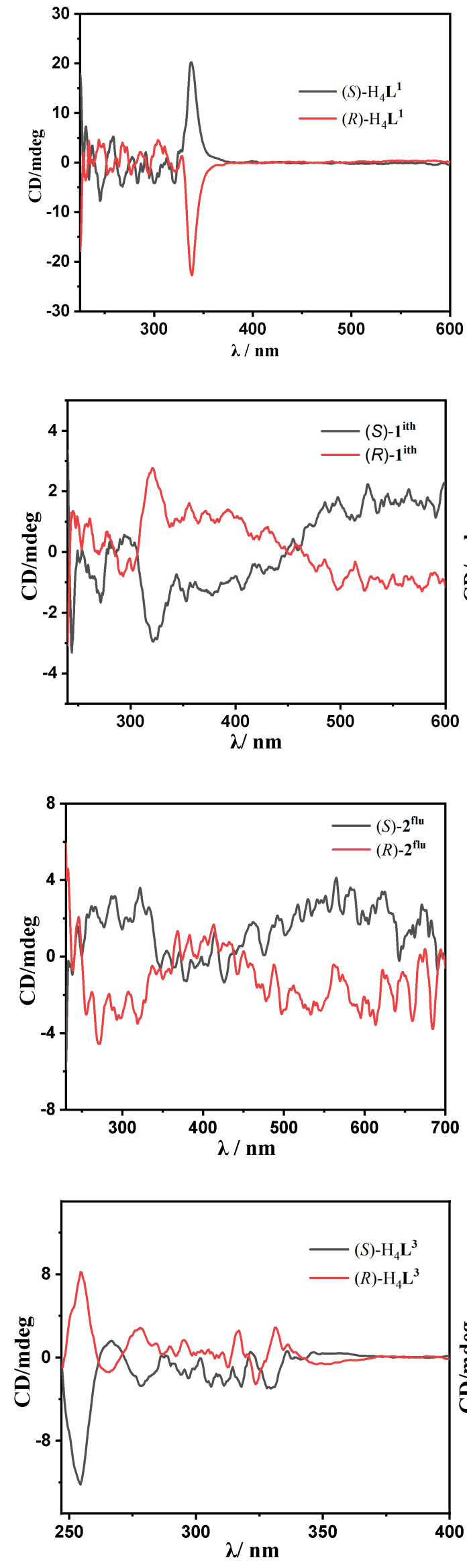
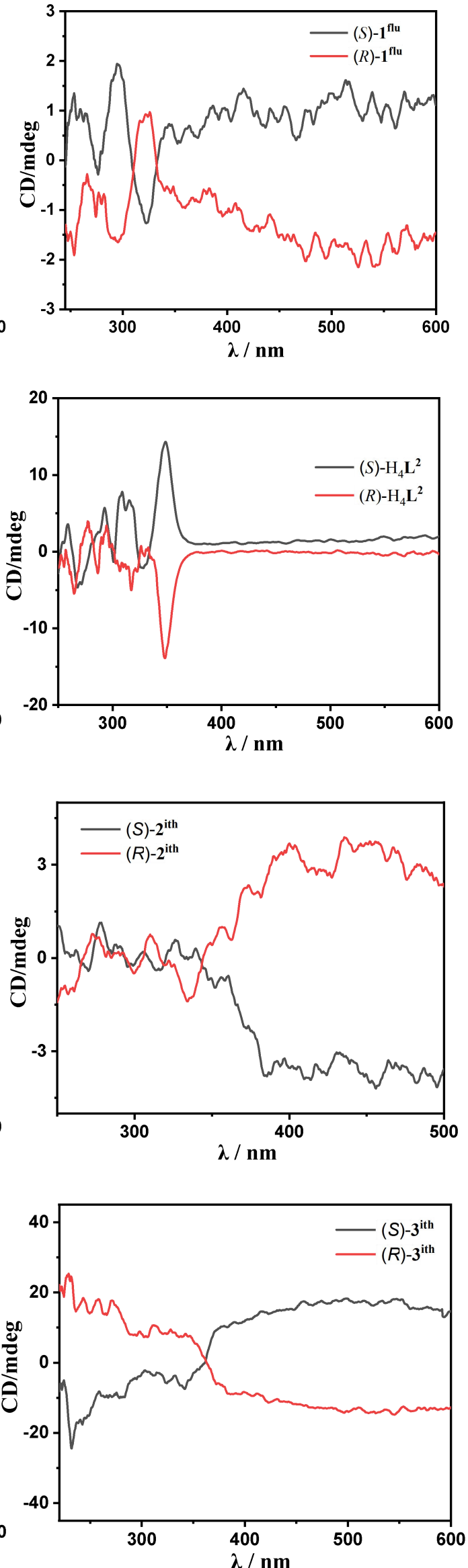
7. Figure S3. FT-IR spectra
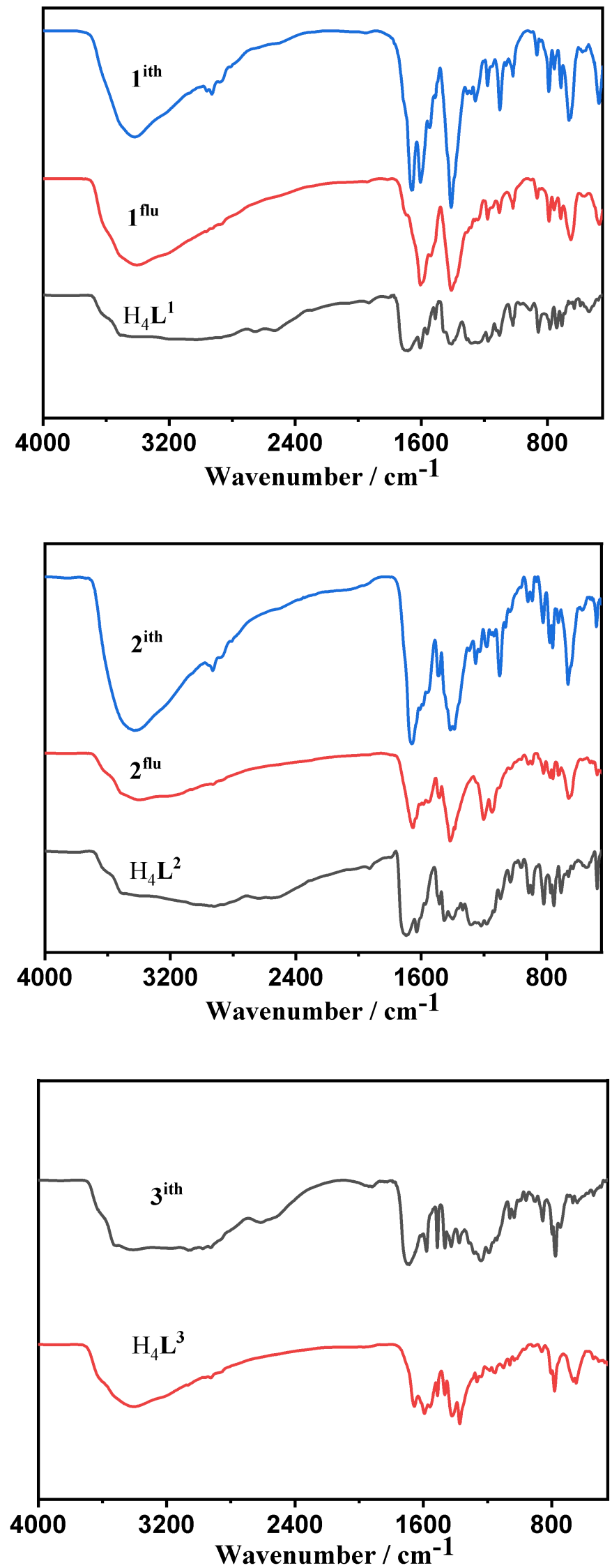


\section{Table S2. Crystal data and structure refinement}

\begin{tabular}{|c|c|c|c|}
\hline Identification code & $\mathrm{Me}_{4} \mathbf{L}^{1}$-P-Ir & $1^{\text {flu }}$ & $2^{\text {flu }}$ \\
\hline Empirical formula & $\mathrm{C}_{56} \mathrm{H}_{54} \mathrm{O}_{10} \mathrm{NPClIr}$ & $\mathrm{C}_{40} \mathrm{H}_{22} \mathrm{O}_{20} \mathrm{Zr}_{3}$ & $\mathrm{C}_{56} \mathrm{H}_{30} \mathrm{O}_{20} \mathrm{Zr}_{3}$ \\
\hline Formula weight & 1159.62 & 1096.23 & 1296.46 \\
\hline Temperature $(\mathrm{K})$ & 298 & 173 & 173 \\
\hline Wavelength $(\AA)$ & 0.71073 & 0.71073 & 0.71073 \\
\hline Crystal system & Monoclinic & Orthorhombic & Orthorhombic \\
\hline Space group & $C 2$ & $F \mathrm{mmm}$ & $F \mathrm{mmm}$ \\
\hline $\mathrm{a}(\AA)$ & $26.211(11)$ & $18.1834(15)$ & $16.031(2)$ \\
\hline $\mathrm{b}(\AA)$ & $11.674(5)$ & $33.744(2)$ & $36.971(5)$ \\
\hline c $(\AA)$ & $20.371(9)$ & $34.489(2)$ & $44.102(5)$ \\
\hline$a\left({ }^{\circ}\right)$ & 90 & 90 & 90 \\
\hline$\beta\left({ }^{\circ}\right)$ & $107.548(8)$ & 90 & 90 \\
\hline$\gamma\left({ }^{\circ}\right)$ & 90 & 90 & 90 \\
\hline Volume $\left(\AA^{3}\right), Z$ & $5943(4), 4$ & $21162(3), 8$ & $26138(6), 8$ \\
\hline Density (calculated) $\left(\mathrm{g} / \mathrm{cm}^{3}\right)$ & 1.296 & 0.688 & 0.659 \\
\hline Absorption coefficient $\left(\mathrm{mm}^{-1}\right)$ & 2.370 & 0.323 & 0.267 \\
\hline$F(000)$ & 2344 & 4336 & 5168 \\
\hline Reflections collected / unique & 19490/9768 & $15639 / 2937$ & $31094 / 2761$ \\
\hline Completeness to theta & $24.713,99.2$ & $20.809,97.4$ & $18.840,97.8$ \\
\hline$R_{\text {int }}$ & 0.042 & 0.073 & 0.097 \\
\hline Refinement method & $\begin{array}{c}\text { Full-matrix } \\
\text { least-squares on } \mathrm{F}^{2}\end{array}$ & $\begin{array}{c}\text { Full-matrix } \\
\text { least-squares on } \mathrm{F}^{2}\end{array}$ & $\begin{array}{c}\text { Full-matrix } \\
\text { least-squares on } \mathrm{F}^{2}\end{array}$ \\
\hline Data / restraints / parameters & $9768 / 331 / 567$ & $2937 / 168 / 150$ & $2761 / 262 / 163$ \\
\hline Goodness of fit on $\mathrm{F}^{2}$ & 0.959 & 1.128 & 1.064 \\
\hline Final R indices $[\mathrm{I}>2 \operatorname{sigma}(\mathrm{I})]$ & $\begin{array}{c}R_{1}=0.0348, w R_{2}= \\
0.0773\end{array}$ & $\begin{array}{c}R_{1}=0.0547, w R_{2}= \\
0.1720\end{array}$ & $\begin{array}{c}R_{1}=0.0764, w R_{2}= \\
0.1983\end{array}$ \\
\hline $\mathrm{R}$ indices (all data) & $\begin{array}{c}R_{1}=0.0431, w R_{2}= \\
0.0805\end{array}$ & $\begin{array}{c}R_{1}=0.0871, w R_{2}= \\
0.1961\end{array}$ & $\begin{array}{c}R_{1}=0.1093, w R_{2}= \\
0.2325\end{array}$ \\
\hline Absolute structure parameter & $0.016(6)$ & - & - \\
\hline Residue peak / hole $\left(\mathrm{e}^{-3}\right)$ & $0.64 /-0.40$ & $0.79 /-0.75$ & $1.02 /-0.57$ \\
\hline
\end{tabular}




\begin{tabular}{|c|c|c|c|}
\hline Identification code & $1^{\text {ith }}$ & $2^{\text {ith }}$ & $3^{\text {ith }}$ \\
\hline Empirical formula & $\mathrm{C}_{42} \mathrm{H}_{30} \mathrm{O}_{17} \mathrm{Zr}_{3}$ & $\mathrm{C}_{87} \mathrm{H}_{57} \mathrm{O}_{22} \mathrm{Zr}_{6}$ & $\mathrm{C}_{58} \mathrm{H}_{38} \mathrm{O}_{17} \mathrm{Zr}_{3}$ \\
\hline Formula weight & 1080.32 & 2001.66 & 1280.54 \\
\hline Temperature $(\mathrm{K})$ & 173.0 & 173.0 & 173.0 \\
\hline Wavelength $(\AA)$ & 1.54178 & 1.54178 & 1.54178 \\
\hline Crystal system & Trigonal & Trigonal & Trigonal \\
\hline Space group & $R 32$ & $R 32$ & $R 32$ \\
\hline $\mathrm{a}(\AA)$ & $30.653(4)$ & $35.5419(10)$ & $30.5594(14)$ \\
\hline $\mathrm{b}(\AA)$ & $30.653(4)$ & $35.5419(10)$ & $30.5594(14)$ \\
\hline $\mathrm{c}(\AA)$ & $24.900(7)$ & 25.9661(17) & $25.331(3)$ \\
\hline$a\left(^{\circ}\right)$ & 90 & 90 & 90 \\
\hline$\beta\left({ }^{\circ}\right)$ & 90 & 90 & 90 \\
\hline$\gamma\left({ }^{\circ}\right)$ & 120 & 120 & 120 \\
\hline Volume $\left(\AA^{3}\right), Z$ & $20262(7), 9$ & $28407(2), 6$ & $20487(3), 9$ \\
\hline Density (calculated) $\left(\mathrm{g} / \mathrm{cm}^{3}\right)$ & 0.797 & 0.702 & 0.934 \\
\hline Absorption coefficient $\left(\mathrm{mm}^{-1}\right)$ & 3.103 & 2.880 & 3.133 \\
\hline$F(000)$ & 4842 & 5970 & 5778 \\
\hline Reflections collected/ unique & $15456 / 2731$ & $20457 / 4931$ & $44425 / 6587$ \\
\hline Completeness to theta & $39.968,99.0$ & $44.486,99.8$ & $59.368,99.1$ \\
\hline$R_{\text {int }}$ & 0.1952 & 0.1485 & 0.0813 \\
\hline Refinement method & $\begin{array}{c}\text { Full-matrix } \\
\text { least-squares on } \mathrm{F}^{2} \\
\end{array}$ & $\begin{array}{c}\text { Full-matrix } \\
\text { least-squares on } \mathrm{F}^{2}\end{array}$ & $\begin{array}{c}\text { Full-matrix } \\
\text { least-squares on } \mathrm{F}^{2}\end{array}$ \\
\hline Data / restraints / parameters & $2731 / 385 / 160$ & $4931 / 552 / 250$ & $6587 / 217 / 266$ \\
\hline Goodness of fit on $\mathrm{F}^{2}$ & 0.931 & 1.568 & 1.058 \\
\hline Final $\mathrm{R}$ indices $[\mathrm{I}>2 \operatorname{sigma}(\mathrm{I})]$ & $\begin{array}{c}R_{1}=0.0543, w R_{2}= \\
0.1178\end{array}$ & $\begin{array}{c}R_{1}=0.1574, w R_{2}= \\
0.3701\end{array}$ & $\begin{array}{c}R_{1}=0.0685, w R_{2}= \\
0.1814\end{array}$ \\
\hline $\mathrm{R}$ indices (all data) & $\begin{array}{c}R_{1}=0.0979, w R_{2}= \\
0.1356\end{array}$ & $\begin{array}{c}R_{1}=0.2876, w R_{2}= \\
0.4665\end{array}$ & $\begin{array}{c}R_{1}=0.0845, w R_{2}= \\
0.2040\end{array}$ \\
\hline Absolute structure parameter & $0.45(3)$ & $0.47(11)$ & $0.51(2)$ \\
\hline Residue peak / hole $\left(\mathrm{e} \AA^{-3}\right)$ & $0.93 /-0.63$ & $2.398 /-1.683$ & $2.46 /-0.96$ \\
\hline
\end{tabular}




\section{Table S3. Selected bond lengths and angles}

\begin{tabular}{|c|c|c|c|}
\hline \multicolumn{4}{|c|}{ Selected bond lengths $[\AA]$ and angles $\left[^{\circ}\right]$ of $\mathrm{Me}_{4} \mathbf{L}^{\mathbf{1}}$-P-Ir } \\
\hline $\operatorname{Ir}(1)-\mathrm{P}(1)$ & $2.237(2)$ & $\operatorname{Ir}(1)-\mathrm{Cl}(1)$ & $2.354(3)$ \\
\hline $\operatorname{Ir}(1)-C(50)$ & $2.246(10)$ & $\operatorname{Ir}(1)-C(54)$ & $2.090(12)$ \\
\hline $\operatorname{Ir}(1)-C(49)$ & $2.251(9)$ & $\operatorname{Ir}(1)-C(53)$ & $2.090(10)$ \\
\hline $\mathrm{P}(1)-\operatorname{Ir}(1)-\mathrm{Cl}(1)$ & $90.24(8)$ & $\mathrm{P}(1)-\operatorname{Ir}(1)-\mathrm{C}(50)$ & $163.1(4)$ \\
\hline $\mathrm{P}(1)-\operatorname{Ir}(1)-\mathrm{C}(49)$ & $160.8(3)$ & $\mathrm{O}(2)-\mathrm{P}(1)-\mathrm{N}(1)$ & $99.1(3)$ \\
\hline$C(49)-C(50)-\operatorname{Ir}(1)$ & $72.2(6)$ & $\mathrm{O}(1)-\mathrm{P}(1)-\operatorname{Ir}(1)$ & $108.89(19)$ \\
\hline $\mathrm{C}(50)-\operatorname{Ir}(1)-\mathrm{Cl}(1)$ & $88.9(4)$ & $\mathrm{N}(1)-\mathrm{P}(1)-\operatorname{Ir}(1)$ & $119.4(2)$ \\
\hline $\mathrm{C}(50)-\operatorname{Ir}(1)-\mathrm{C}(49)$ & $36.1(4)$ & $\mathrm{C}(51)-\mathrm{C}(50)-\operatorname{Ir}(1)$ & $107.8(9)$ \\
\hline $\mathrm{C}(54)-\operatorname{Ir}(1)-\mathrm{P}(1)$ & $91.8(3)$ & $C(49)-C(50)-\operatorname{Ir}(1)$ & $72.2(6)$ \\
\hline $\mathrm{C}(54)-\operatorname{Ir}(1)-\mathrm{Cl}(1)$ & $160.2(3)$ & $\mathrm{C}(53)-\mathrm{C}(54)-\operatorname{Ir}(1)$ & $70.2(7)$ \\
\hline $\mathrm{C}(54)-\operatorname{Ir}(1)-\mathrm{C}(50)$ & $94.7(5)$ & $\mathrm{C}(47)-\mathrm{C}(54)-\operatorname{Ir}(1)$ & $114.1(8)$ \\
\hline $\mathrm{C}(54)-\operatorname{Ir}(1)-\mathrm{C}(49)$ & $79.6(4)$ & $C(50)-C(49)-\operatorname{Ir}(1)$ & $71.8(5)$ \\
\hline $\mathrm{C}(49)-\operatorname{Ir}(1)-\mathrm{Cl}(1)$ & $92.2(3)$ & $\mathrm{C}(48)-\mathrm{C}(49)-\operatorname{Ir}(1)$ & $112.6(6)$ \\
\hline $\mathrm{C}(53)-\operatorname{Ir}(1)-\mathrm{P}(1)$ & $94.4(3)$ & $\mathrm{C}(54)-\mathrm{C}(53)-\operatorname{Ir}(1)$ & $70.3(6)$ \\
\hline $\mathrm{C}(53)-\operatorname{Ir}(1)-\mathrm{Cl}(1)$ & $159.7(4)$ & $\mathrm{O}(1)-\mathrm{P}(1)-\operatorname{Ir}(1)$ & $108.89(19)$ \\
\hline $\mathrm{C}(53)-\operatorname{Ir}(1)-\mathrm{C}(50)$ & $81.0(5)$ & $\mathrm{N}(1)-\mathrm{P}(1)-\operatorname{Ir}(1)$ & $119.4(2)$ \\
\hline $\mathrm{C}(53)-\operatorname{Ir}(1)-\mathrm{C}(54)$ & $39.5(5)$ & $\mathrm{C}(51)-\mathrm{C}(50)-\operatorname{Ir}(1)$ & $107.8(9)$ \\
\hline$C(53)-\operatorname{Ir}(1)-C(49)$ & $89.9(4)$ & $\mathrm{O}(2)-\mathrm{P}(1)-\operatorname{Ir}(1)$ & $117.7(2)$ \\
\hline \multicolumn{4}{|c|}{ Symmetry transformations used to generate equivalent atoms: } \\
\hline
\end{tabular}

\begin{tabular}{|c|c|c|c|}
\hline \multicolumn{4}{|c|}{ Selected bond lengths $[\AA]$ and angles $\left[^{\circ}\right]$ of $\mathbf{1}^{\text {flu }}$} \\
\hline $\mathrm{Zr}(1)-\mathrm{O}(4)$ & $2.191(7)$ & $\mathrm{Zr}(1)-\mathrm{O}(3)$ & $2.189(5)$ \\
\hline $\mathrm{Zr}(1)-\mathrm{O}(5)$ & $2.205(8)$ & $\mathrm{Zr}(2)-\mathrm{O}(2)$ & $2.264(5)$ \\
\hline $\mathrm{Zr}(2)-\mathrm{O}(4)$ & $2.146(4)$ & $\mathrm{Zr}(2)-\mathrm{O}(5)$ & $2.133(4)$ \\
\hline $\mathrm{Zr}(2)-\mathrm{O}(7)$ & $2.215(8)$ & $\mathrm{Zr}(2)-\mathrm{O}(6)$ & $2.206(7)$ \\
\hline $\mathrm{O}(4)-\mathrm{Zr}(1)-\mathrm{Zr}(2)$ & $35.76(11)$ & $\mathrm{O}(4)-\mathrm{Zr}(1)-\mathrm{O}(5)$ & $71.30(15)$ \\
\hline $\mathrm{O}(3)-\operatorname{Zr}(1)-\operatorname{Zr}(2)$ & $75.46(12)$ & $\mathrm{O}(3)-\mathrm{Zr}(1)-\mathrm{O}(4)$ & $77.7(2)$ \\
\hline $\mathrm{O}(3)-\mathrm{Zr}(1)-\mathrm{O}(5)$ & $78.6(2)$ & $\mathrm{O}(5)-\mathrm{Zr}(1)-\mathrm{Zr}(2)$ & $35.54(10)$ \\
\hline $\mathrm{O}(2)-\operatorname{Zr}(2)-\operatorname{Zr}(1)$ & $71.82(13)$ & $\mathrm{O}(4)-\operatorname{Zr}(2)-\operatorname{Zr}(1)$ & $36.65(18)$ \\
\hline $\mathrm{O}(4)-\mathrm{Zr}(2)-\mathrm{O}(2)$ & $74.7(2)$ & $\mathrm{O}(4)-\mathrm{Zr}(2)-\mathrm{O}(6)$ & $86.4(3)$ \\
\hline $\mathrm{O}(5)-\operatorname{Zr}(2)-\operatorname{Zr}(1)$ & $36.9(2)$ & $\mathrm{O}(5)-\mathrm{Zr}(2)-\mathrm{O}(2)$ & $76.2(2)$ \\
\hline $\mathrm{O}(5)-\mathrm{Zr}(2)-\mathrm{O}(4)$ & $73.6(3)$ & $\mathrm{O}(5)-\mathrm{Zr}(2)-\mathrm{O}(6)$ & $146.24(15)$ \\
\hline $\mathrm{O}(5)-\mathrm{Zr}(2)-\mathrm{O}(7)$ & $87.9(3)$ & $\mathrm{O}(7)-\mathrm{Zr}(2)-\mathrm{O}(2)$ & $72.86(17)$ \\
\hline
\end{tabular}




\begin{tabular}{|l|l|l|l|}
\hline $\mathrm{O}(6)-\mathrm{Zr}(2)-\mathrm{Zr}(1)$ & $118.58(13)$ & $\mathrm{C}(11)-\mathrm{O}(2)-\mathrm{Zr}(2)$ & $133.9(5)$ \\
\hline $\mathrm{O}(6)-\mathrm{Zr}(2)-\mathrm{O}(2)$ & $72.33(15)$ & $\mathrm{Zr}(2)-\mathrm{O}(4)-\mathrm{Zr}(1)$ & $107.6(2)$ \\
\hline $\mathrm{O}(6)-\mathrm{Zr}(2)-\mathrm{O}(7)$ & $94.3(3)$ & $\mathrm{C}(11)-\mathrm{O}(3)-\mathrm{Zr}(1)$ & $132.3(4)$ \\
\hline $\mathrm{O}(7)-\mathrm{Zr}(2)-\mathrm{Zr}(1)$ & $119.67(11)$ & $\mathrm{Zr}(2)-\mathrm{O}(5)-\mathrm{Zr}(1)$ & $107.5(3)$ \\
\hline $\begin{array}{l}\text { Symmetry transformations used to generate equivalent atoms: } \\
\# 1-\mathrm{x}, \mathrm{y}, \mathrm{z} \quad \# 2-\mathrm{x},-\mathrm{y},-\mathrm{z} \quad \# 3 \mathrm{x},-\mathrm{y},-\mathrm{z} \quad \# 4-\mathrm{x},-\mathrm{y}, \mathrm{z} \\
\# 5 \mathrm{x},-\mathrm{y}, \mathrm{z} \quad \# 6 \mathrm{x}, \mathrm{y},-\mathrm{z} \quad \# 7-\mathrm{x}+1 / 2,-\mathrm{y}+1 / 2, \mathrm{z} \quad \# 8-\mathrm{x}+1 / 2, \mathrm{y},-\mathrm{z}+1 / 2\end{array}$ \\
\hline
\end{tabular}

\begin{tabular}{|c|c|c|c|}
\hline \multicolumn{4}{|c|}{ Selected bond lengths $[\AA]$ and angles $\left[^{\circ}\right]$ of $\mathbf{2}^{\text {flu }}$} \\
\hline $\mathrm{Zr}(2)-\mathrm{O}(5)$ & $2.147(6)$ & $\mathrm{Zr}(2)-\mathrm{O}(7)$ & $2.09(2)$ \\
\hline $\mathrm{Zr}(2)-\mathrm{O}(2)$ & $2.276(8)$ & $\mathrm{Zr}(1)-\mathrm{O}(5)$ & $2.207(15)$ \\
\hline $\mathrm{Zr}(2)-\mathrm{O}(4)$ & $2.149(7)$ & $\mathrm{Zr}(1)-\mathrm{O}(4)$ & $2.200(11)$ \\
\hline $\mathrm{Zr}(2)-\mathrm{O}(6)$ & $2.209(11)$ & $\mathrm{Zr}(1)-\mathrm{O}(3)$ & $2.169(9)$ \\
\hline $\mathrm{O}(5)-\operatorname{Zr}(2)-\operatorname{Zr}(1)$ & $37.0(4)$ & $\mathrm{O}(5)-\mathrm{Zr}(2)-\mathrm{O}(2)$ & $76.9(3)$ \\
\hline $\mathrm{O}(5)-\mathrm{Zr}(2)-\mathrm{O}(4)$ & $73.7(5)$ & $\mathrm{O}(2)-\operatorname{Zr}(2)-\operatorname{Zr}(1)$ & $72.3(2)$ \\
\hline $\mathrm{O}(5)-\mathrm{Zr}(2)-\mathrm{O}(6)$ & $145.9(2)$ & $\mathrm{O}(4)-\operatorname{Zr}(2)-\operatorname{Zr}(1)$ & $36.8(3)$ \\
\hline $\mathrm{O}(4)-\mathrm{Zr}(2)-\mathrm{O}(2)$ & $74.4(4)$ & $\mathrm{O}(5)-\operatorname{Zr}(1)-\operatorname{Zr}(2)$ & $35.81(19)$ \\
\hline $\mathrm{O}(4)-\mathrm{Zr}(2)-\mathrm{O}(6)$ & $86.3(5)$ & $\mathrm{O}(4)-\operatorname{Zr}(1)-\operatorname{Zr}(2)$ & $35.8(2)$ \\
\hline $\mathrm{O}(6)-\operatorname{Zr}(2)-\operatorname{Zr}(1)$ & $118.7(3)$ & $\mathrm{O}(4)-\mathrm{Zr}(1)-\mathrm{O}(5)$ & $71.6(3)$ \\
\hline $\mathrm{O}(6)-\mathrm{Zr}(2)-\mathrm{O}(2)$ & $71.1(3)$ & $\mathrm{O}(3)-\operatorname{Zr}(1)-\operatorname{Zr}(2)$ & $75.8(2)$ \\
\hline $\mathrm{O}(7)-\operatorname{Zr}(2)-\operatorname{Zr}(1)$ & $119.9(2)$ & $\mathrm{O}(3)-\mathrm{Zr}(1)-\mathrm{O}(5)$ & $78.4(4)$ \\
\hline $\mathrm{O}(7)-\mathrm{Zr}(2)-\mathrm{O}(5)$ & $88.0(6)$ & $\mathrm{O}(3)-\mathrm{Zr}(1)-\mathrm{O}(4)$ & $78.0(4)$ \\
\hline $\mathrm{O}(7)-\mathrm{Zr}(2)-\mathrm{O}(2)$ & 73.4(4) & $\operatorname{Zr}(2)-\mathrm{O}(5)-\mathrm{Zr}(1)$ & $107.2(5)$ \\
\hline $\mathrm{O}(7)-\mathrm{Zr}(2)-\mathrm{O}(4)$ & $145.8(3)$ & $\operatorname{Zr}(2)-\mathrm{O}(4)-\mathrm{Zr}(1)$ & $107.4(4)$ \\
\hline $\mathrm{O}(7)-\mathrm{Zr}(2)-\mathrm{O}(6)$ & $93.9(6)$ & & \\
\hline \multicolumn{4}{|c|}{ Symmetry transformations used to generate equivalent atoms: } \\
\hline$\# 1 \mathrm{x},-\mathrm{y},-\mathrm{z} \quad \# 2-\mathrm{x}, \mathrm{y}, \mathrm{z}$ & $\# 3-\mathrm{x},-\mathrm{y},-\mathrm{z} \quad \# 4$ & & \\
\hline$\# 5-\mathrm{x},-\mathrm{y}, \mathrm{z} \quad \# 6 \mathrm{x},-\mathrm{y}, \mathrm{z}$ & $\# 7-\mathrm{x}+1 / 2, \mathrm{y},-\mathrm{z}+1 / 2$ & $\# 8-x+1 / 2,-y+1 / 2, z$ & \\
\hline
\end{tabular}

\begin{tabular}{|c|c|c|c|}
\hline \multicolumn{4}{|c|}{ Selected bond lengths $[\AA]$ and angles [ $\left.{ }^{\circ}\right]$ of $\mathbf{1}^{\text {ith }}$} \\
\hline $\mathrm{Zr}(1)-\mathrm{Zr}(2)$ & $3.355(3)$ & $\mathrm{Zr}(2)-\mathrm{O}(8)$ & $2.48(3)$ \\
\hline $\mathrm{Zr}(1)-\mathrm{O}(8)$ & $1.97(2)$ & $\mathrm{Zr}(2)-\mathrm{O}(4)$ & $2.50(2)$ \\
\hline $\mathrm{Zr}(1)-\mathrm{O}(5)$ & $2.25(2)$ & $\mathrm{Zr}(2)-\mathrm{O}(9)$ & $2.210(15)$ \\
\hline $\mathrm{Zr}(1)-\mathrm{O}(6)$ & $2.019(5)$ & $\mathrm{Zr}(2)-\mathrm{O}(1 \mathrm{~W})$ & $2.05(3)$ \\
\hline $\mathrm{Zr}(1)-\mathrm{O}(7)$ & $2.160(18)$ & $\mathrm{O}(6)-\mathrm{Zr}(1)-\mathrm{Zr}(2)$ & $75.34(10)$ \\
\hline $\mathrm{O}(8)-\mathrm{Zr}(1)-\mathrm{O}(5)$ & $100.2(9)$ & $\mathrm{O}(6)-\mathrm{Zr}(1)-\mathrm{O}(5)$ & $135.0(7)$ \\
\hline $\mathrm{O}(8)-\mathrm{Zr}(1)-\mathrm{O}(6)$ & $91.0(7)$ & $\mathrm{O}(6)-\mathrm{Zr}(1)-\mathrm{O}(7)$ & $57.7(7)$ \\
\hline
\end{tabular}




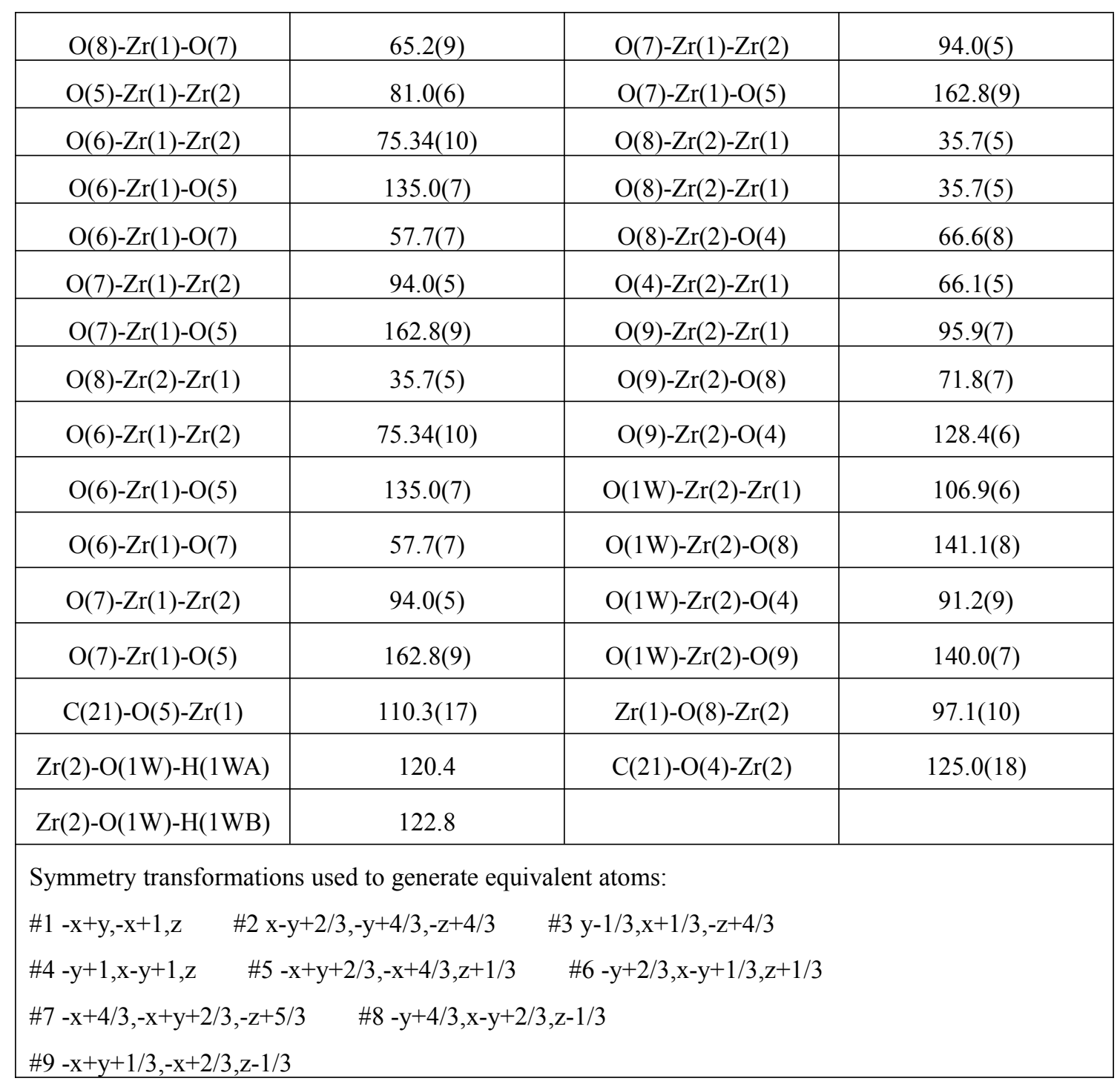

\begin{tabular}{|c|c|c|c|}
\hline \multicolumn{4}{|c|}{ Selected bond lengths $[\AA]$ and angles [ $\left.{ }^{\circ}\right]$ of $\mathbf{2}^{\text {ith }}$} \\
\hline $\mathrm{Zr}(1)-\mathrm{Zr}(2)$ & $2.374(10)$ & $\mathrm{Zr}(2)-\mathrm{O}(3)$ & $2.23(3)$ \\
\hline $\mathrm{Zr}(1)-\mathrm{O}(3)$ & $2.46(4)$ & $\mathrm{Zr}(2)-\mathrm{O}(6)$ & $2.02(4)$ \\
\hline $\mathrm{Zr}(1)-\mathrm{O}(2)$ & $2.09(3)$ & $\mathrm{Zr}(2)-\mathrm{O}(1 \mathrm{~W})$ & $2.06(4)$ \\
\hline $\mathrm{Zr}(2)-\mathrm{Zr}(1)-\mathrm{O}(3)$ & $55.0(10)$ & $\mathrm{O}(2)-\mathrm{Zr}(1)-\mathrm{Zr}(2)$ & $105.3(12)$ \\
\hline $\mathrm{O}(2)-\mathrm{Zr}(1)-\mathrm{O}(3)$ & $59.1(13)$ & $\mathrm{O}(3)-\mathrm{Zr}(2)-\mathrm{Zr}(1)$ & $64.3(12)$ \\
\hline $\mathrm{O}(2)-\mathrm{Zr}(1)-\mathrm{O}(7)$ & $75.8(15)$ & $\mathrm{O}(7)-\mathrm{Zr}(2)-\mathrm{Zr}(1)$ & $58.4(5)$ \\
\hline $\mathrm{O}(7)-\mathrm{Zr}(1)-\mathrm{Zr}(2)$ & $54.4(4)$ & $\mathrm{O}(7)-\mathrm{Zr}(2)-\mathrm{O}(3)$ & $78.7(14)$ \\
\hline $\mathrm{O}(7)-\mathrm{Zr}(1)-\mathrm{O}(3)$ & $72.2(13)$ & $\mathrm{O}(6)-\mathrm{Zr}(2)-\mathrm{Zr}(1)$ & $88.8(14)$ \\
\hline $\mathrm{O}(6)-\mathrm{Zr}(2)-\mathrm{O}(1 \mathrm{~W})$ & $78.3(15)$ & $\mathrm{O}(6)-\mathrm{Zr}(2)-\mathrm{O}(3)$ & $141.6(16)$ \\
\hline $\mathrm{O}(1 \mathrm{~W})-\mathrm{Zr}(2)-\mathrm{Zr}(1)$ & $99.4(13)$ & $\mathrm{O}(6)-\mathrm{Zr}(2)-\mathrm{O}(7)$ & $111.3(19)$ \\
\hline $\mathrm{O}(1 \mathrm{~W})-\mathrm{Zr}(2)-\mathrm{O}(3)$ & $79.7(14)$ & $\mathrm{Zr}(2)-\mathrm{O}(7)-\mathrm{Zr}(1)$ & $67.1(7)$ \\
\hline $\mathrm{O}(1 \mathrm{~W})-\mathrm{Zr}(2)-\mathrm{O}(7)$ & $154.3(13)$ & $\mathrm{Zr}(2)-\mathrm{O}(1 \mathrm{~W})-\mathrm{H}(1 \mathrm{WA})$ & 116.1 \\
\hline $\mathrm{Zr}(2)-\mathrm{O}(3)-\mathrm{Zr}(1)$ & $60.6(8)$ & $\mathrm{Zr}(2)-\mathrm{O}(1 \mathrm{~W})-\mathrm{H}(1 \mathrm{WB})$ & 118.0 \\
\hline
\end{tabular}




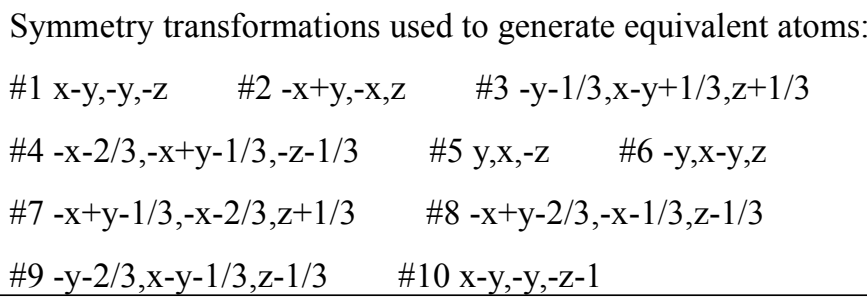

\begin{tabular}{|c|c|c|c|}
\hline \multicolumn{4}{|c|}{ Selected bond lengths $[\AA]$ and angles $\left[^{\circ}\right]$ of $3^{\text {ith }}$} \\
\hline $\mathrm{Zr}(1)-\mathrm{O}(5)$ & $2.225(12)$ & $\mathrm{Zr}(1)-\mathrm{O}(9)$ & $2.182(5)$ \\
\hline $\mathrm{Zr}(1)-\mathrm{O}(6)$ & $2.125(12)$ & $\mathrm{Zr}(2)-\mathrm{O}(6)$ & $1.998(13)$ \\
\hline $\mathrm{Zr}(1)-\mathrm{O}(7)$ & $2.205(10)$ & $\mathrm{Zr}(2)-\mathrm{O}(7)$ & $2.292(9)$ \\
\hline $\mathrm{Zr}(2)-\mathrm{O}(8)$ & $2.0159(11)$ & $\mathrm{O}(9)-\operatorname{Zr}(1)-\operatorname{Zr}(2)$ & $90.6(3)$ \\
\hline $\mathrm{O}(5)-\operatorname{Zr}(1)-\operatorname{Zr}(2)$ & 110.2(3) & $\mathrm{O}(9)-\mathrm{Zr}(1)-\mathrm{O}(5)$ & $77.7(4)$ \\
\hline $\mathrm{O}(6)-\operatorname{Zr}(1)-\operatorname{Zr}(2)$ & $28.5(4)$ & $\mathrm{O}(9)-\mathrm{Zr}(1)-\mathrm{O}(7)$ & $115.1(5)$ \\
\hline $\mathrm{O}(6)-\mathrm{Zr}(1)-\mathrm{O}(5)$ & $85.2(5)$ & $\mathrm{O}(9)-\mathrm{Zr}(1)-\mathrm{O}(1 \mathrm{~W})$ & $143.5(3)$ \\
\hline $\mathrm{O}(6)-\mathrm{Zr}(1)-\mathrm{O}(7)$ & $66.5(4)$ & $\mathrm{O}(1 \mathrm{~W})-\operatorname{Zr}(1)-\operatorname{Zr}(2)$ & $79.5(5)$ \\
\hline $\mathrm{O}(6)-\mathrm{Zr}(1)-\mathrm{O}(9)$ & $71.6(4)$ & $\mathrm{O}(1 \mathrm{~W})-\mathrm{Zr}(1)-\mathrm{O}(5)$ & $73.2(5)$ \\
\hline $\mathrm{O}(6)-\mathrm{Zr}(1)-\mathrm{O}(1 \mathrm{~W})$ & $84.3(5)$ & $\mathrm{O}(1 \mathrm{~W})-\mathrm{Zr}(1)-\mathrm{O}(7)$ & $77.2(5)$ \\
\hline $\mathrm{O}(7)-\operatorname{Zr}(1)-\operatorname{Zr}(2)$ & $37.9(2)$ & $\mathrm{O}(6)-\mathrm{Zr}(2)-\mathrm{O}(7)$ & $66.8(4)$ \\
\hline $\mathrm{O}(7)-\mathrm{Zr}(1)-\mathrm{O}(5)$ & $140.6(4)$ & $\mathrm{O}(6)-\mathrm{Zr}(2)-\mathrm{O}(8)$ & $84.8(3)$ \\
\hline $\mathrm{O}(8)-\mathrm{Zr}(2)-\mathrm{O}(7)$ & $62.3(3)$ & $\mathrm{Zr}(1)-\mathrm{O}(7)-\mathrm{Zr}(2)$ & $105.8(4)$ \\
\hline $\mathrm{C}(29)-\mathrm{O}(5)-\mathrm{Zr}(1)$ & $127.6(9)$ & $\mathrm{Zr}(2)-\mathrm{O}(6)-\mathrm{Zr}(1)$ & $120.9(7)$ \\
\hline $\mathrm{Zr}(1)-\mathrm{O}(1 \mathrm{~W})-\mathrm{H}(1 \mathrm{WA})$ & 109.4 & $\mathrm{Zr}(1)-\mathrm{O}(1 \mathrm{~W})-\mathrm{H}(1 \mathrm{WB})$ & 109.5 \\
\hline $\begin{array}{l}\text { Symmetry transformatio } \\
\begin{array}{l}\# 1-\mathrm{y}, \mathrm{x}-\mathrm{y}, \mathrm{z} \\
\# 2-\mathrm{x}+\mathrm{y}, \\
\# 4-\mathrm{x},-\mathrm{x}+\mathrm{y},-\mathrm{z}+1 \\
\# 5 \mathrm{y}-\mathrm{y}+2 / 3, \mathrm{x}-\mathrm{y}+1 / 3, \mathrm{z}+1 / 3 \\
\# 10-\mathrm{y}+1 / 3, \mathrm{x}-\mathrm{y}+2 / 3, \mathrm{z}-1 / 3\end{array}\end{array}$ & $\begin{array}{l}\text { sed to generate } \\
\# 3-\mathrm{x}+\mathrm{y}-1 / 3 \\
\mathrm{z}+1 \quad \# 6 \mathrm{x}-\mathrm{y}+ \\
\# 8 \mathrm{y}, \mathrm{x},-\mathrm{z}\end{array}$ & $\begin{array}{l}z+1 / 3 \\
/ 3,-z+2 / 3 \\
1 / 3,-x+2 / 3, z-1 / 3\end{array}$ & \\
\hline
\end{tabular}


10. Figures S4-S6. Additional X-ray crystallographic structures

10.1 Figure $\mathrm{S} 4 \mathrm{Zr}_{9}$ clusters that are formed by face sharing of two $\mathrm{Zr}_{6}$ clusters in $1^{\text {ith }} / 3^{\text {ith }}$
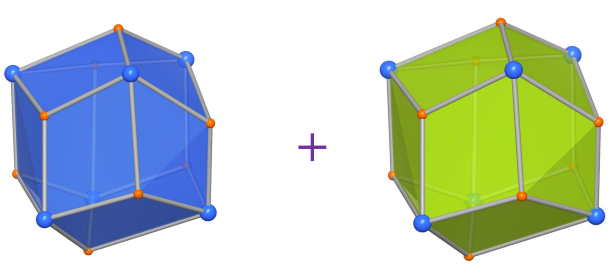

\section{Face sharing}
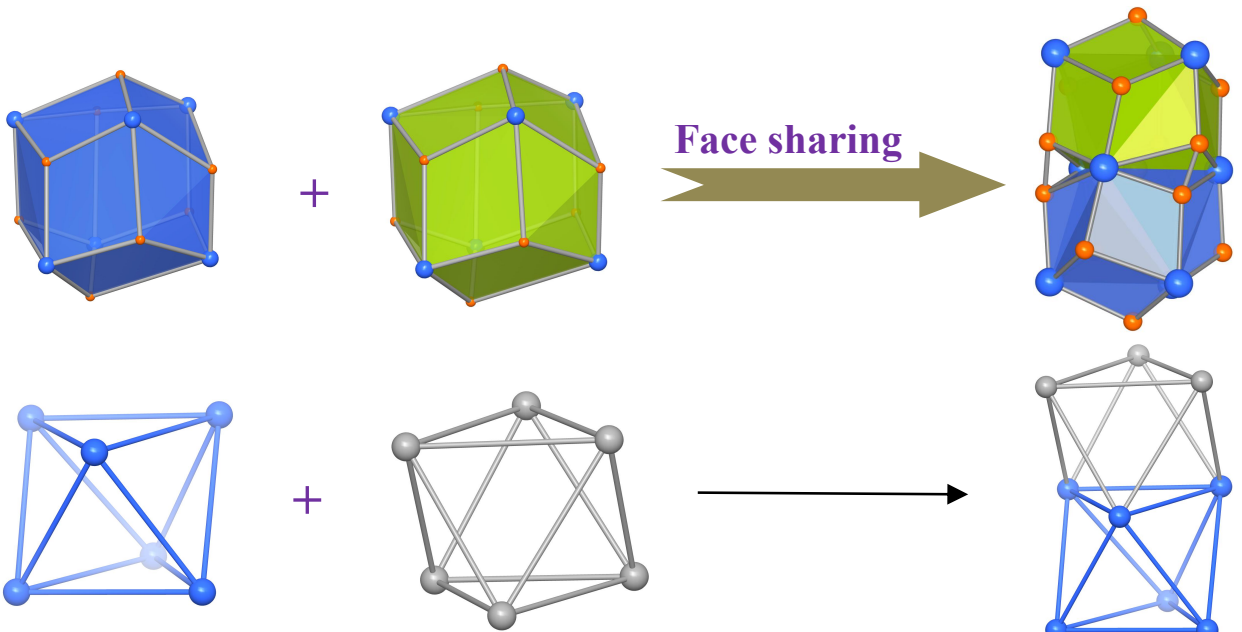

10.2 Figure S5 2-fold disorder of $\mathrm{Zr}_{6}$ clusters to form $\mathrm{Zr}_{12}$ cluster in $2^{\text {ith }}$
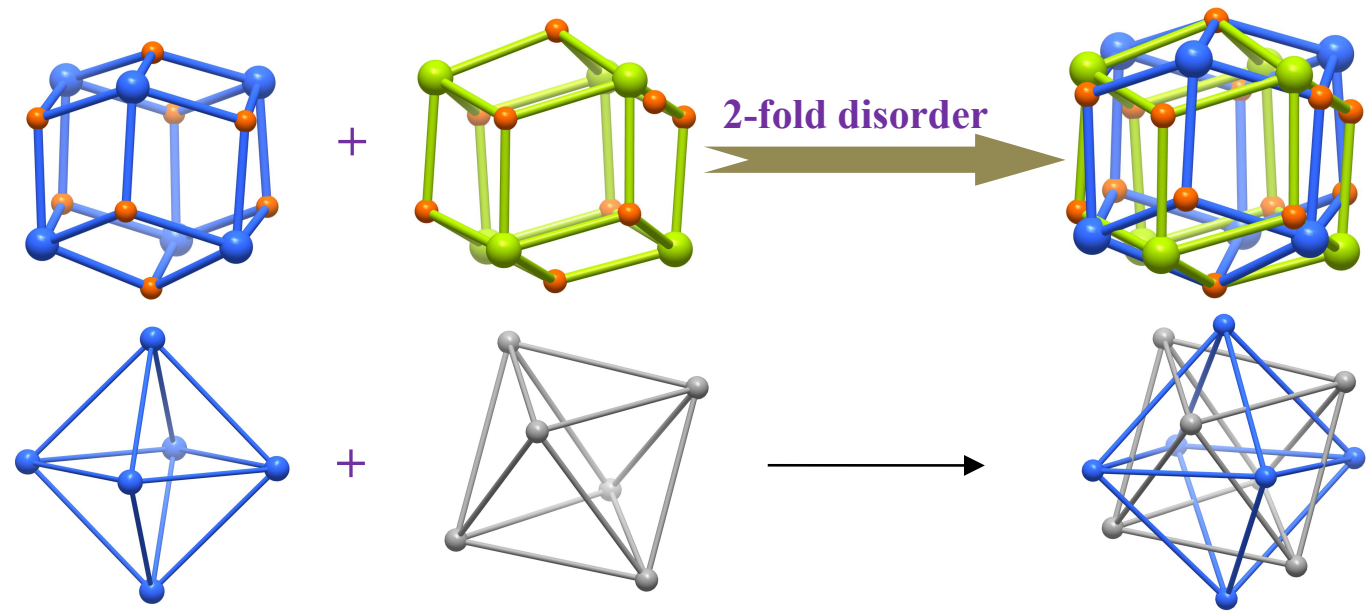

10.3 Figure S6 Triple helicate-cages exist in $\mathbf{1}^{\text {ith }} \mathbf{3}^{\text {ith }}$.
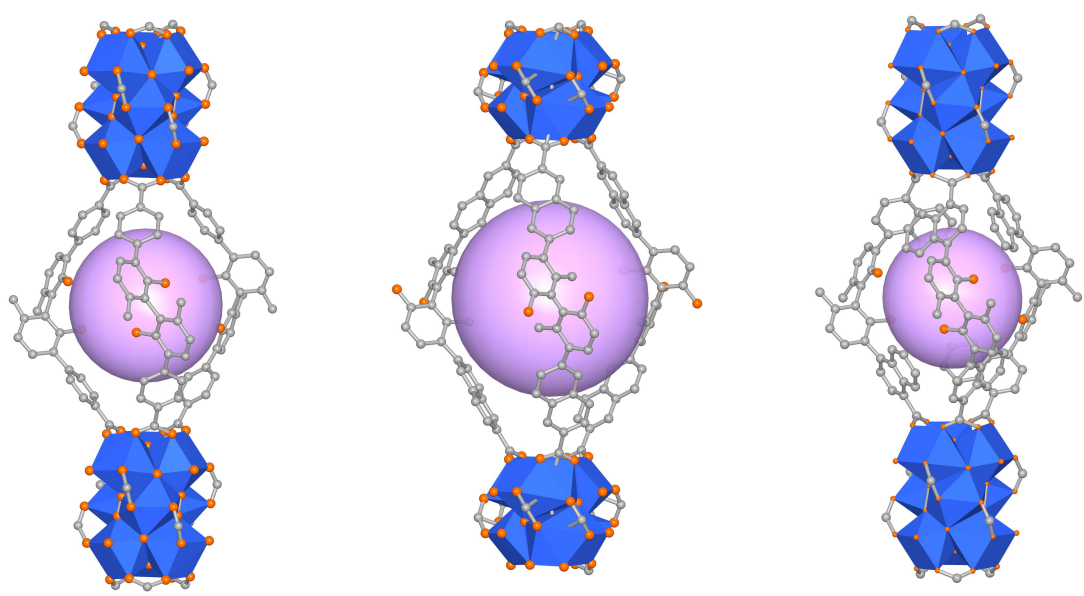


\section{Figure S7. Additional PXRD patterns}
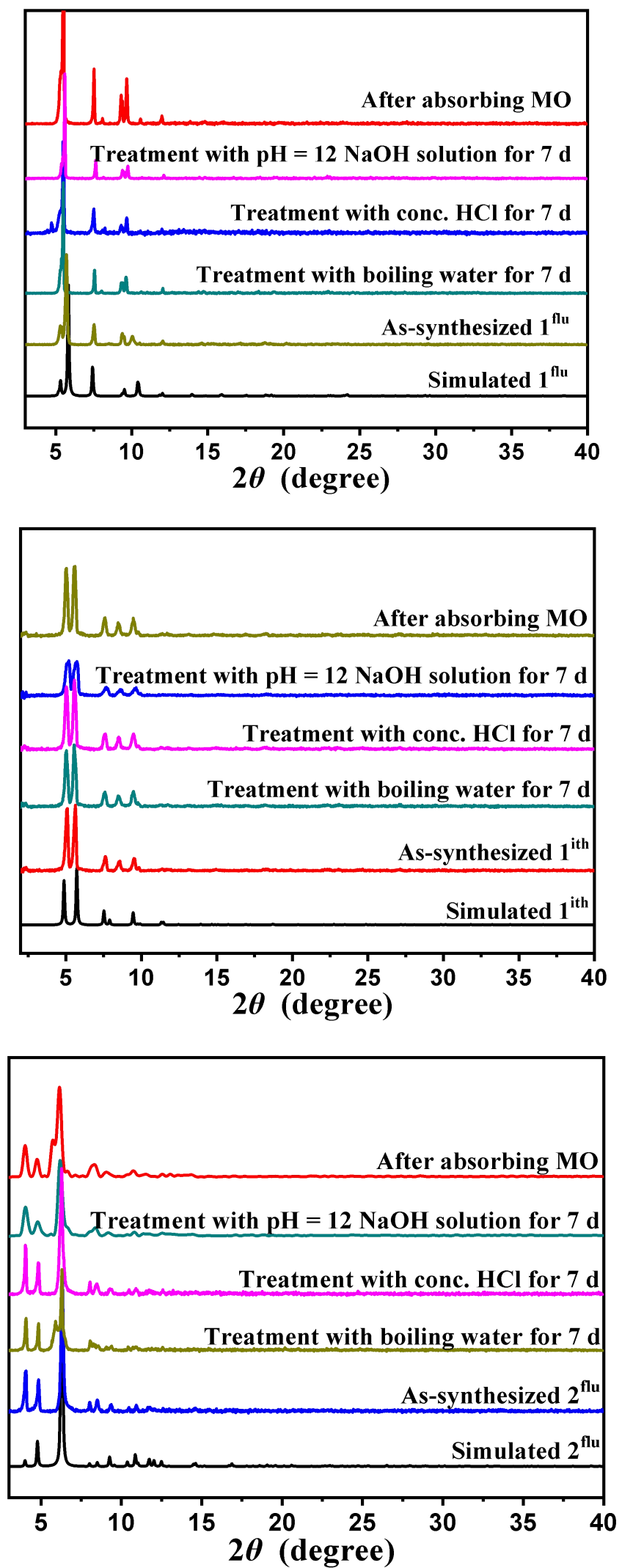

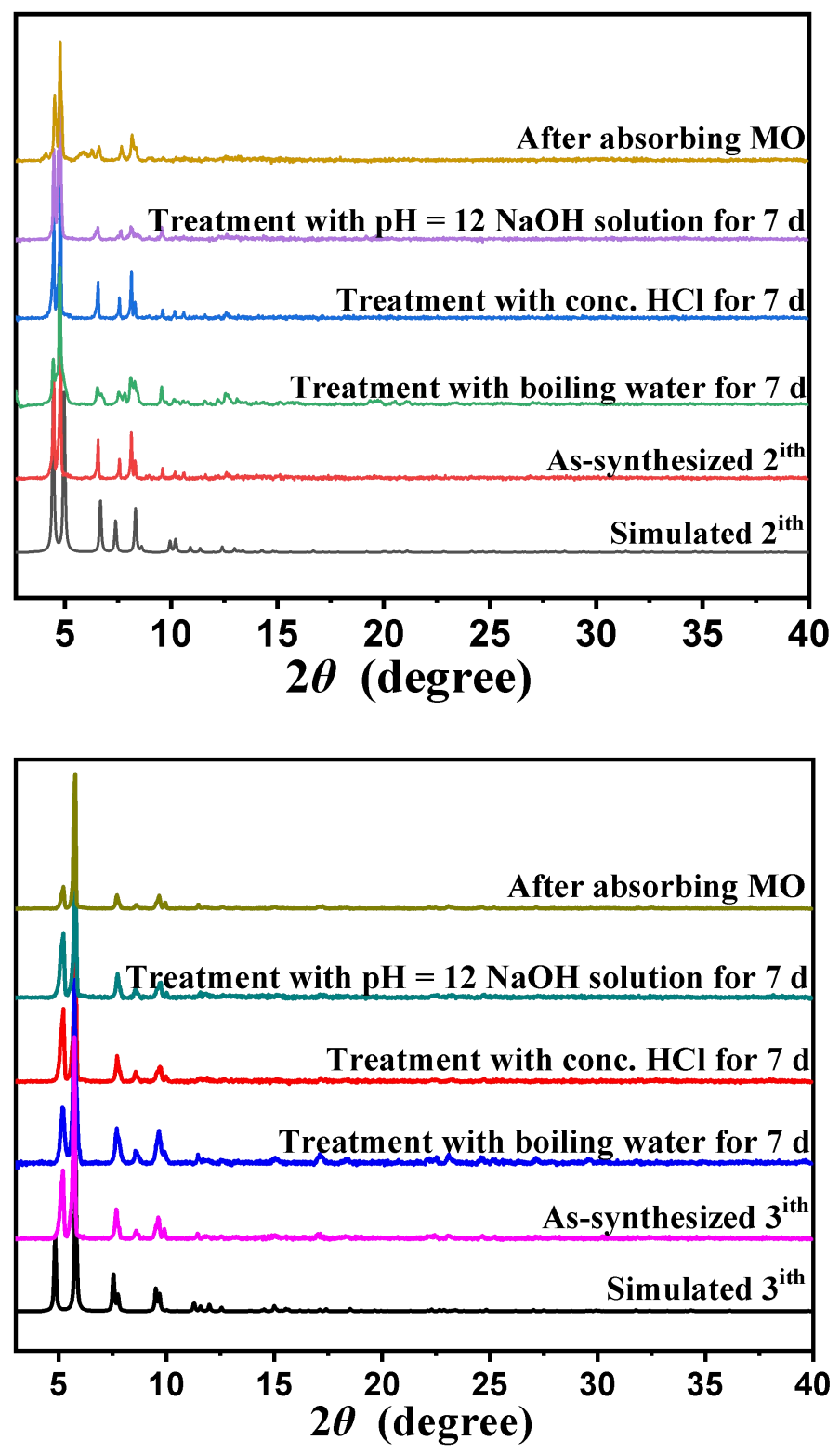
12. Figure $S 8$. $\mathbf{N}_{2}$ adsorption isotherms and BET plots
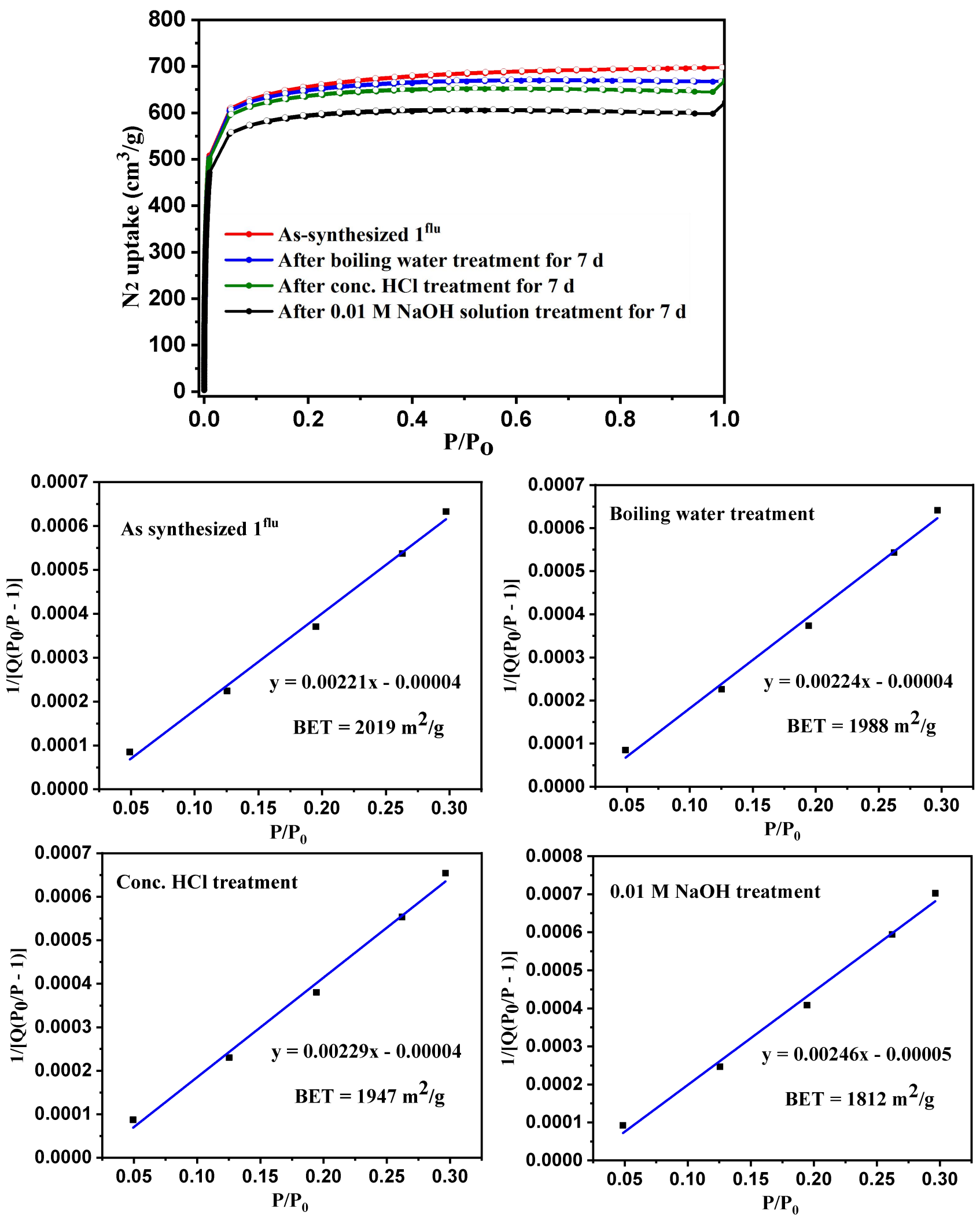

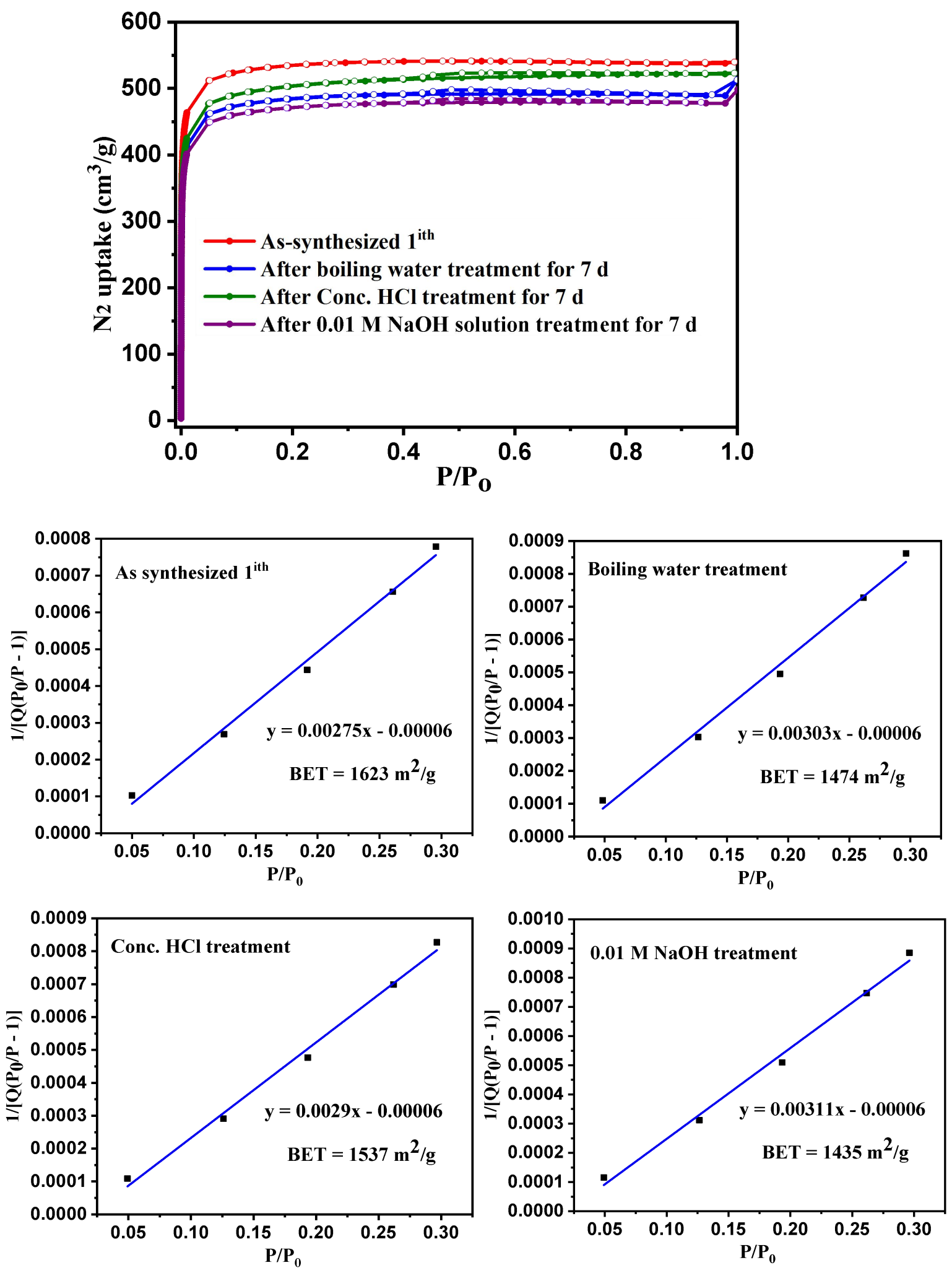

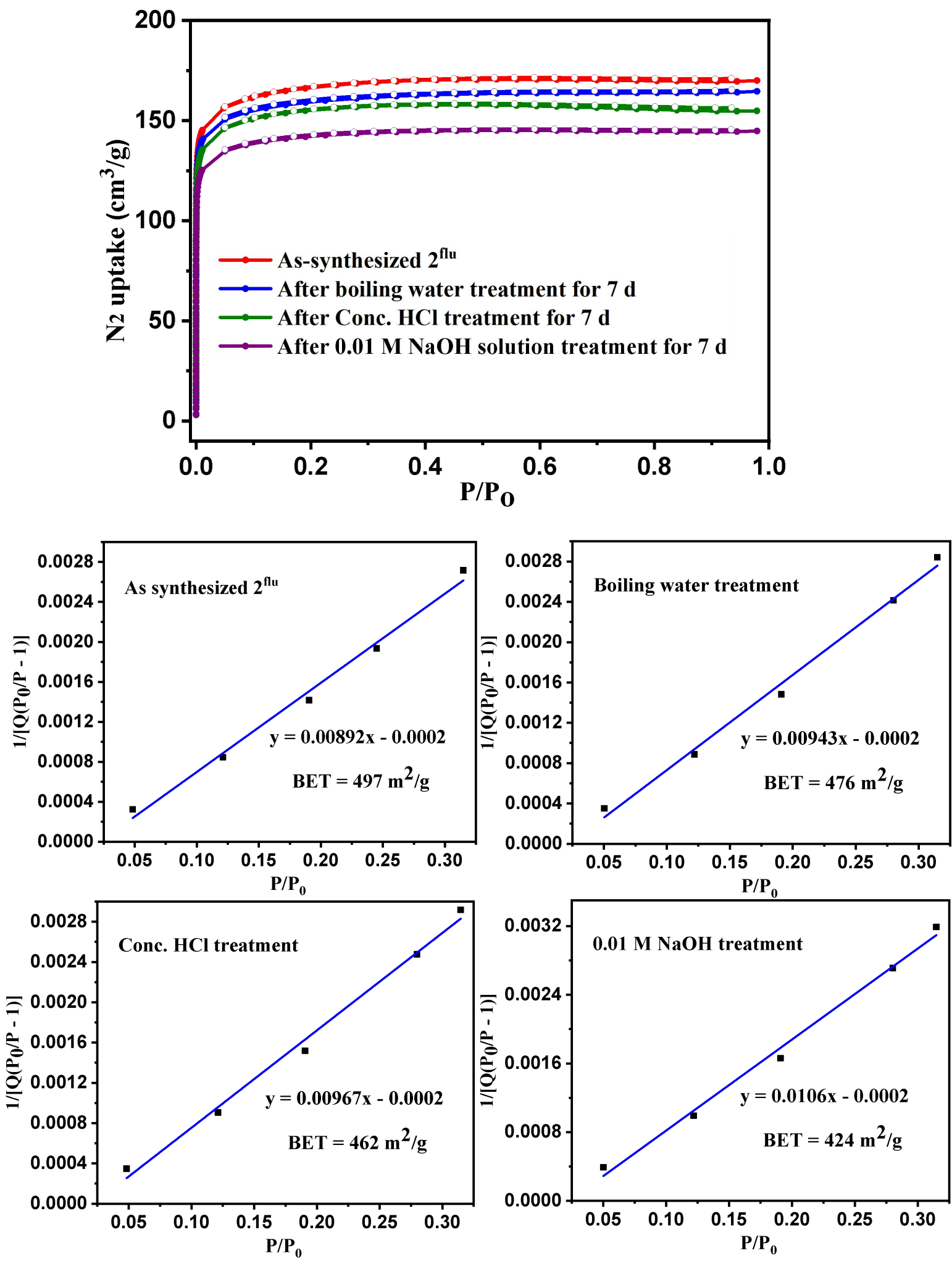

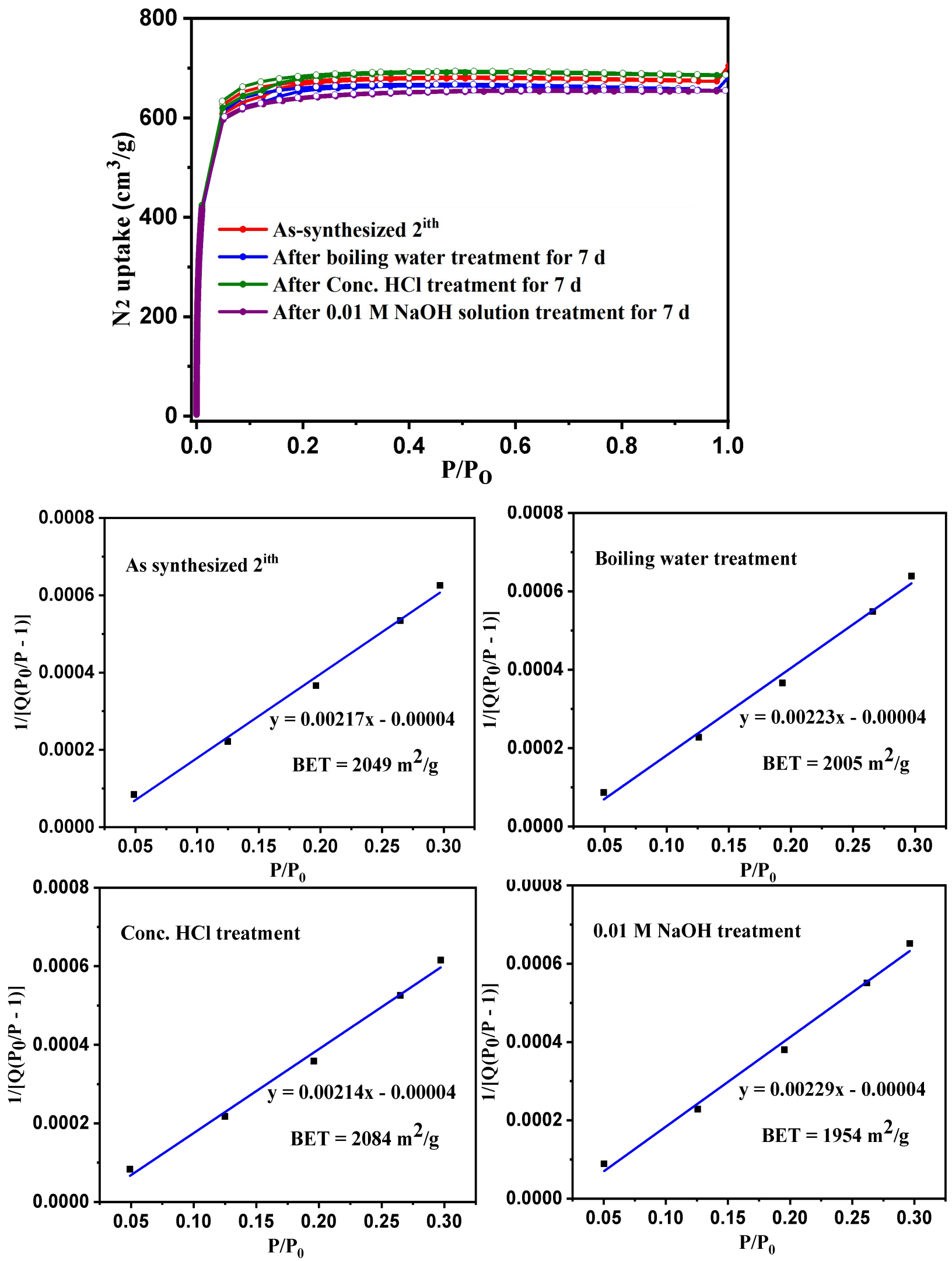

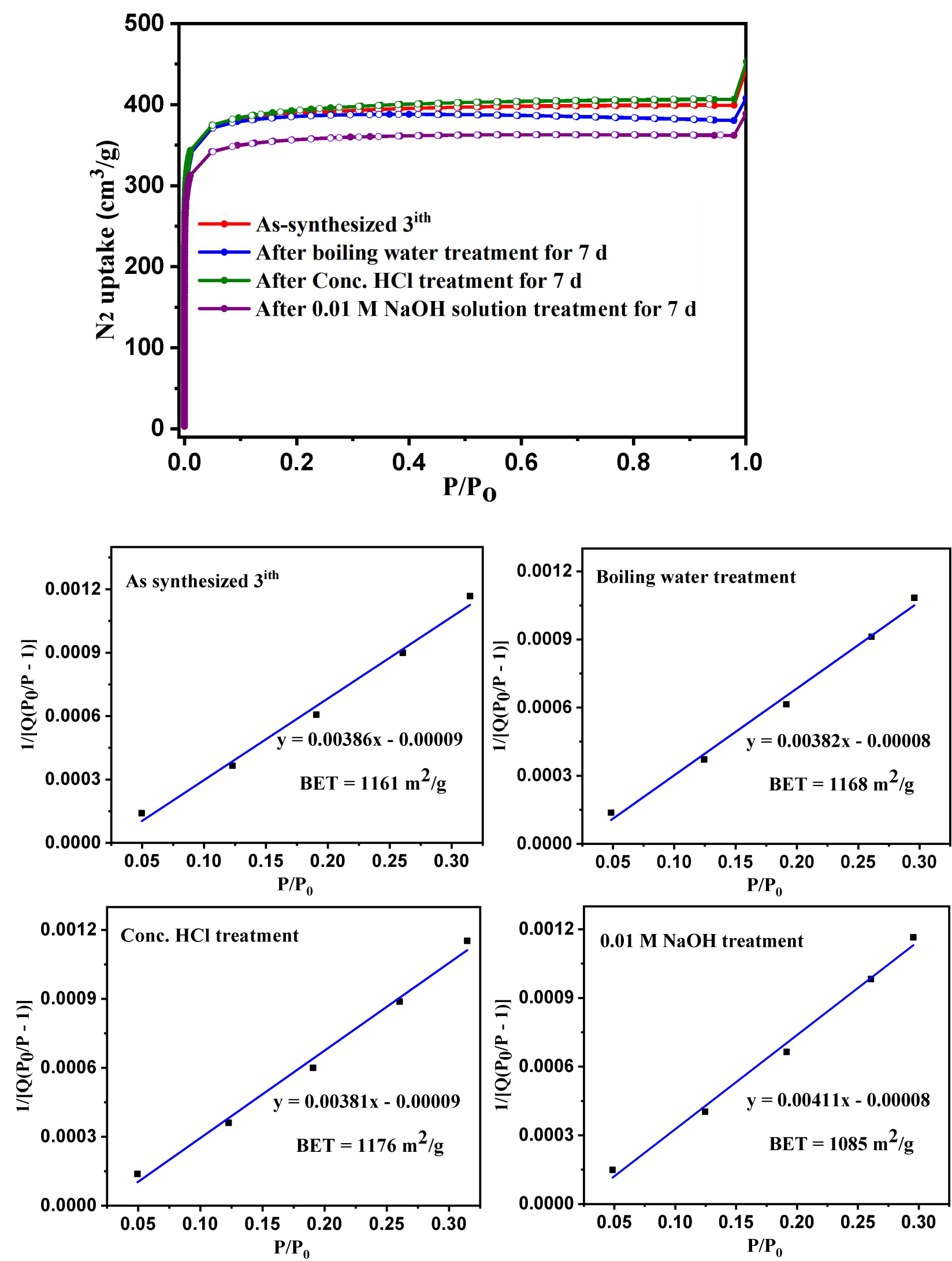
13. Figure S9. Photographs and SEM images. (a, c, e, g, and i) Photographs and (b, $\mathrm{d}, \mathrm{f}, \mathrm{h}$ and $\mathrm{j}$ ) SEM images for $\mathbf{1}^{\mathrm{flu}}, \mathbf{2}^{\text {flu }}$ and $\mathbf{1}^{\text {ith }} \mathbf{3}^{\text {ith }}$, respectively.

(a)

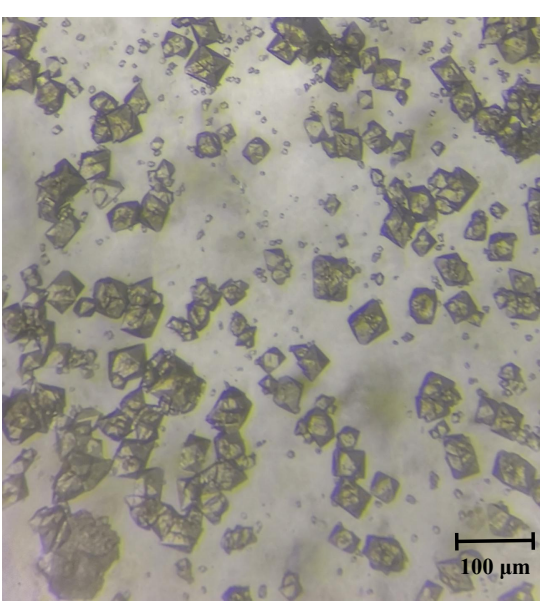

(e)

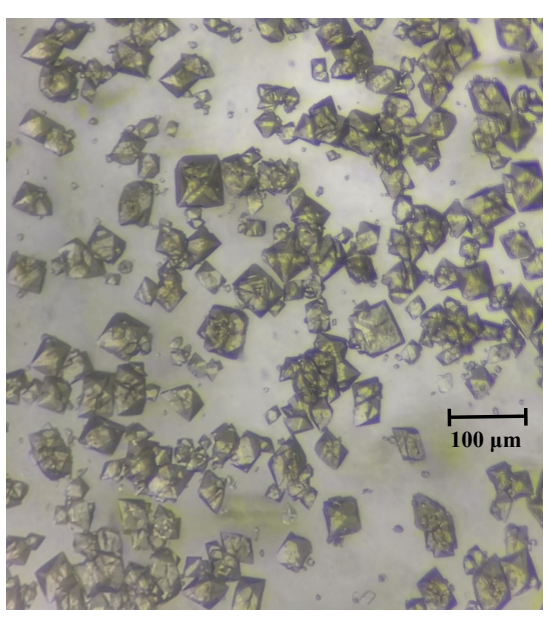

(c)

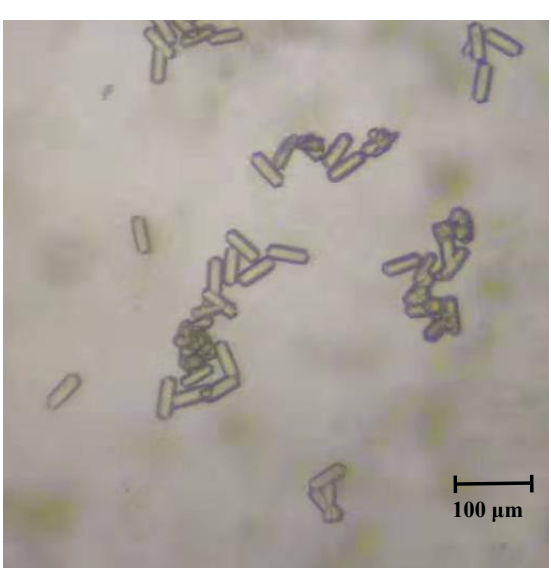

(b)

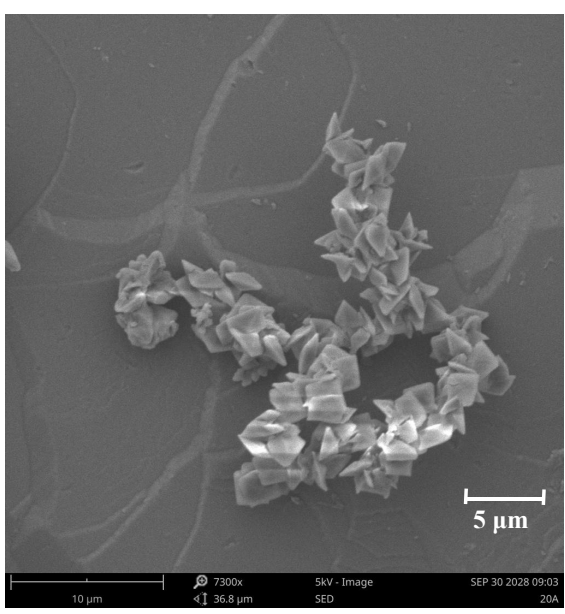

(f)

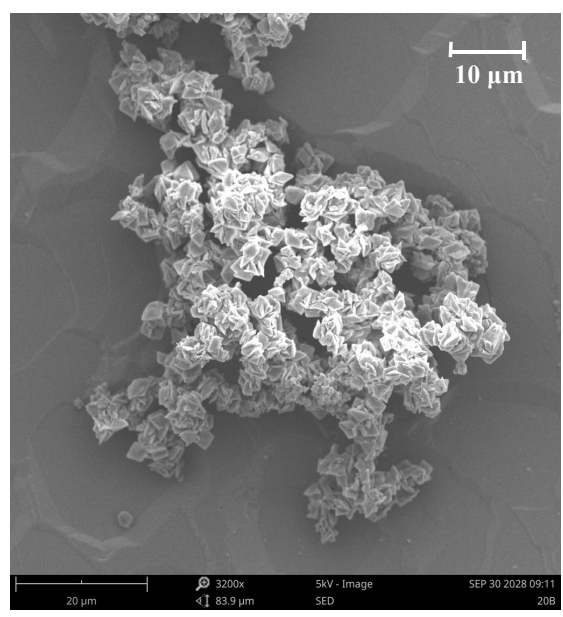

(d)

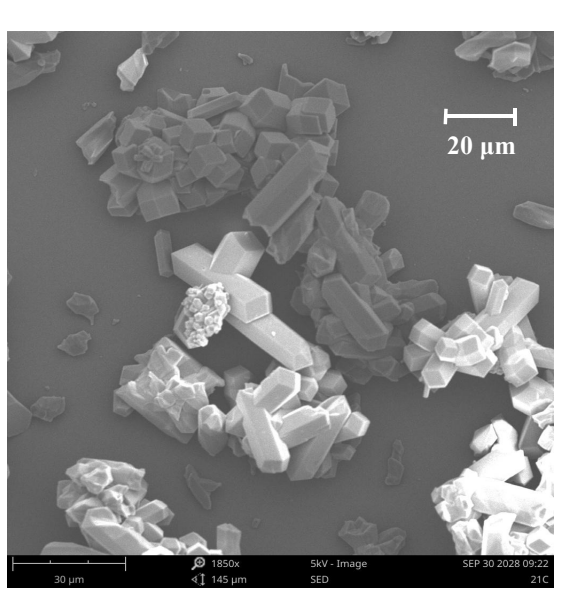


(g)

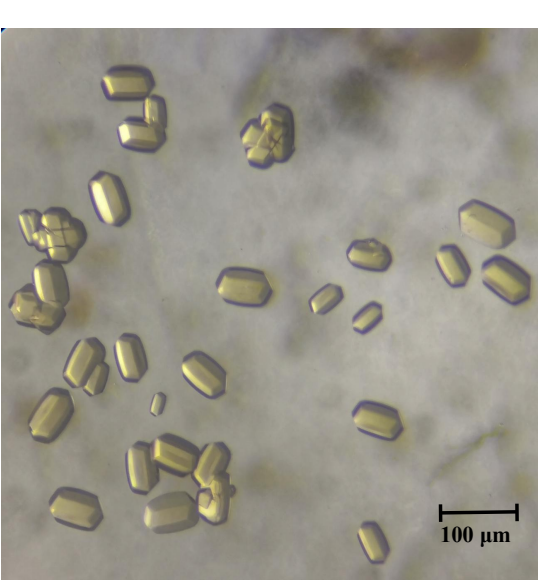

(i)

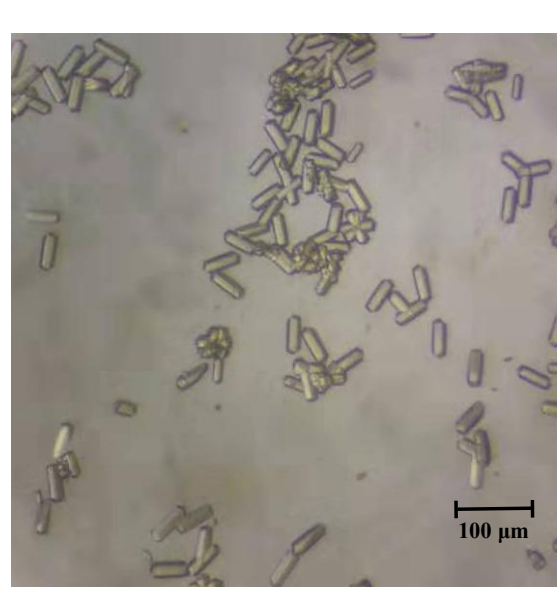

(h)

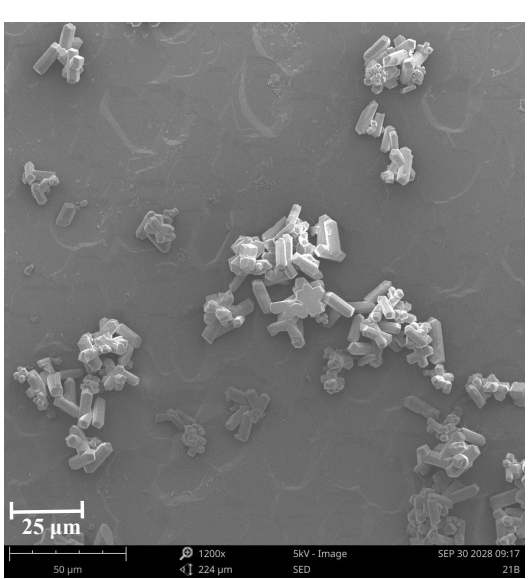

(j)

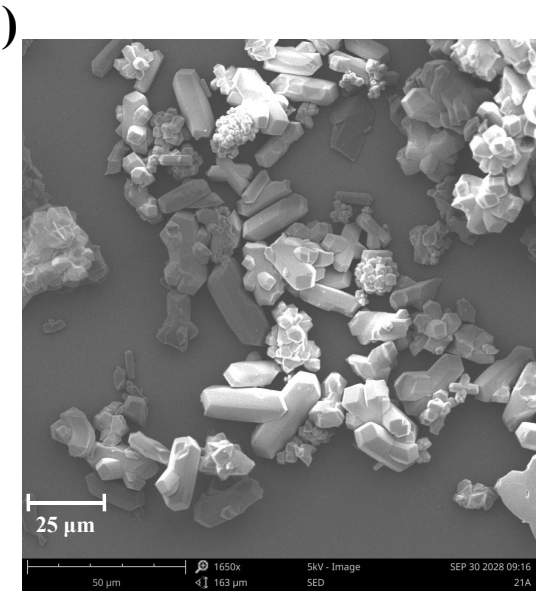

\section{Additional catalytic results}

Table S4 Optimization of the reaction conditions in asymmetric hydrogenation reaction. $^{a}$

\begin{tabular}{|c|c|c|c|c|c|}
\hline entry & solvent & press. (bar) & Ir loading (mol \%) & yield $(\%)^{b}$ & ee $(\%)^{c}$ \\
\hline 1 & $\mathrm{CH}_{3} \mathrm{Cl}$ & 10 & 2 & 99 & 93 \\
\hline 2 & $\mathrm{CH}_{2} \mathrm{Cl}_{2}$ & 10 & 2 & 99 & 98 \\
\hline 3 & $\mathrm{CCl}_{4}$ & 10 & 2 & 99 & 90 \\
\hline 4 & $\mathrm{CH}_{2} \mathrm{ClCH}_{2} \mathrm{Cl}$ & 10 & 2 & 99 & 88 \\
\hline 5 & МeOH & 10 & 2 & 99 & 83 \\
\hline 6 & EtOAc & 10 & 2 & 99 & 95 \\
\hline 7 & THF & 10 & 2 & 99 & 86 \\
\hline 8 & $\mathrm{CH}_{2} \mathrm{Cl}_{2}$ & 5 & 2 & 99 & 98 \\
\hline 9 & $\mathrm{CH}_{2} \mathrm{Cl}_{2}$ & 2.5 & 2 & 93 & 97 \\
\hline 10 & $\mathrm{CH}_{2} \mathrm{Cl}_{2}$ & 5 & 0.5 & 96 & 98 \\
\hline 11 & $\mathrm{CH}_{2} \mathrm{Cl}_{2}$ & 5 & 0.1 & 62 & 82 \\
\hline
\end{tabular}

${ }^{a}$ Reaction conditions: 4a $(0.2 \mathrm{mmol}), \mathbf{1}^{\mathrm{flu}}-\mathbf{P}-\mathbf{I r}$, solvent $(2 \mathrm{~mL}), 20 \mathrm{~h} .{ }^{b}$ Isolated yield. ${ }^{c}$ ee was determined by HPLC analysis. 
14. Figure S10. Kinetic curves

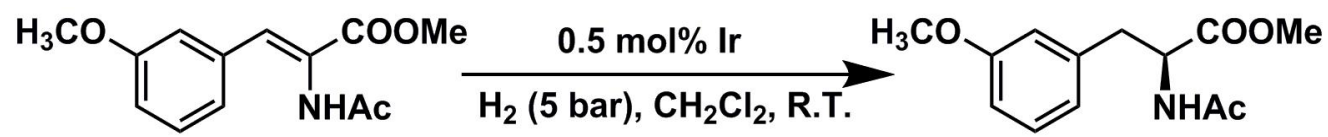
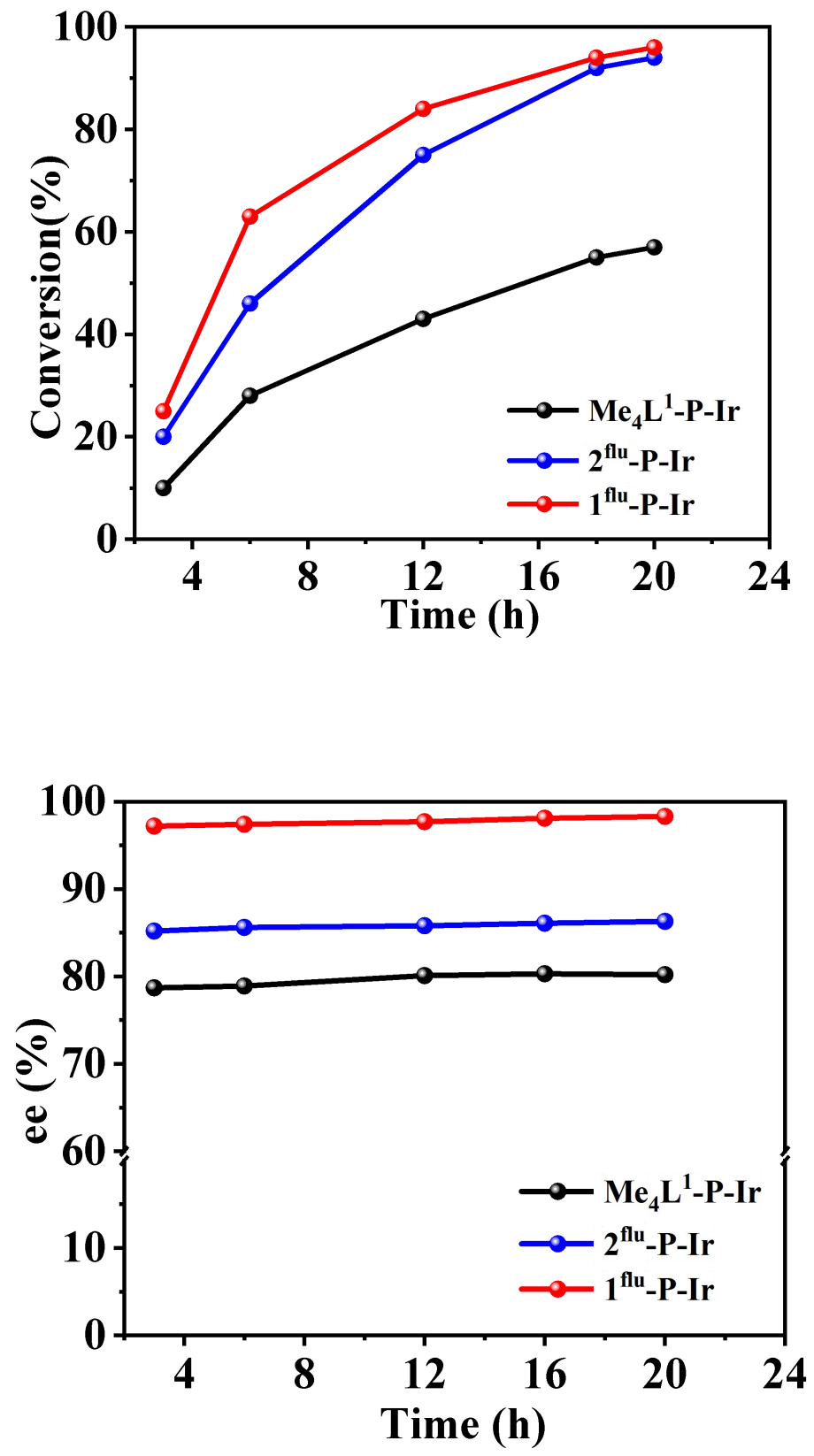
15. Figure S11. Molecular simulations of large substrates.
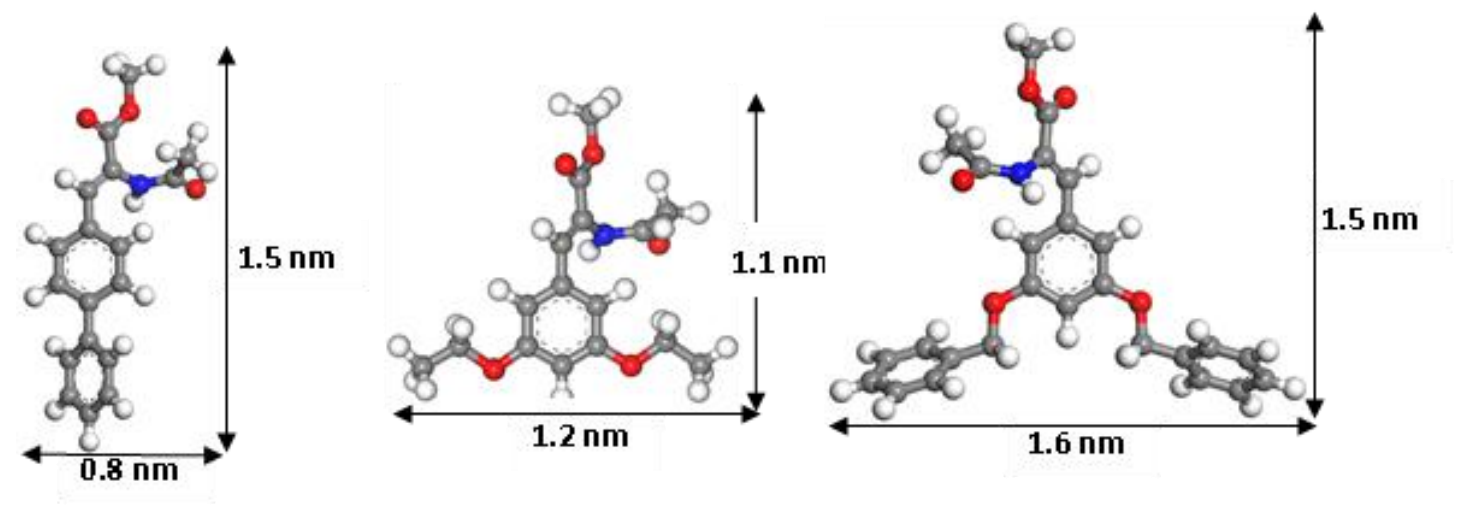

17. Figures S12-S23. Additional NMR spectra.

Figure S12. ${ }^{31} \mathrm{P}$ NMR of $\mathrm{Me}_{4} \mathbf{L}^{1}-\mathbf{P}-\mathrm{Ir}$ and $\mathrm{Me}_{4} \mathbf{L}^{\mathbf{1}}-\mathbf{P}-\mathbf{I r}$ after hydrogenation.

After hydrogenation

$\mathrm{Me}_{4} \mathrm{~L}^{1}$-P-Ir

$\begin{array}{lllllllllllllllllllll}200 & 190 & 180 & 170 & 160 & 150 & 140 & 130 & 120 & 110 & \begin{array}{c}100 \\ \delta / p p m\end{array} & 90 & 80 & 70 & 60 & 50 & 40 & 30 & 20 & 10 & 0\end{array}$

Figure S13. ${ }^{13} \mathrm{C}$ CP/MAS NMR of $\mathbf{1}^{\text {flu }}$-P and $\mathbf{1}^{\text {flu }}$-P-Ir

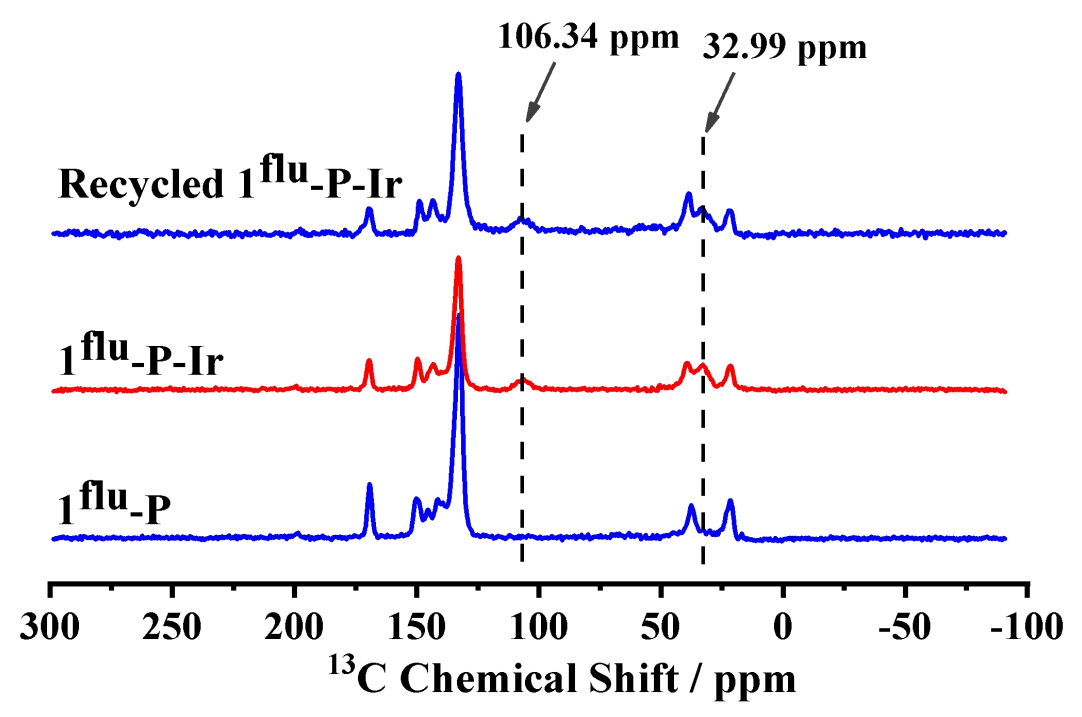


Figure S14. ${ }^{31} \mathrm{P}$ MAS NMR of $\mathbf{1}^{\text {flu }}$-P and $\mathbf{1}^{\text {flu }}$-P-Ir.

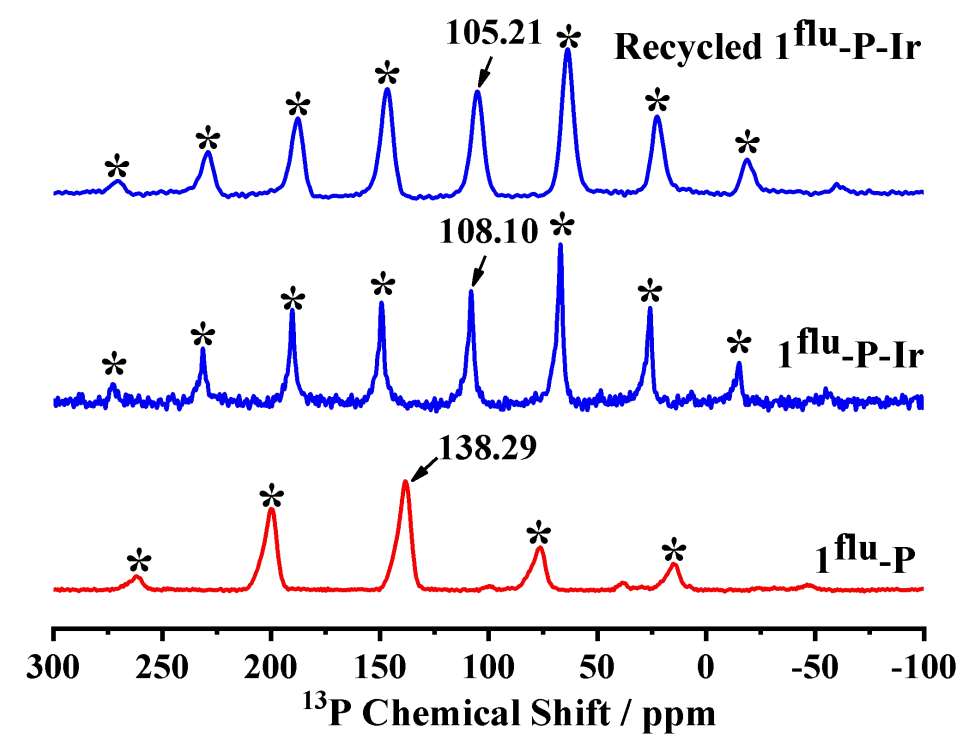

Note: The spinning side bands are labeled with asterisks.

Figure S15. ${ }^{31} \mathrm{P}$ MAS NMR of $\mathbf{2}^{\text {flu }}$-P and $\mathbf{2}^{\text {flu }}$-P-Ir.

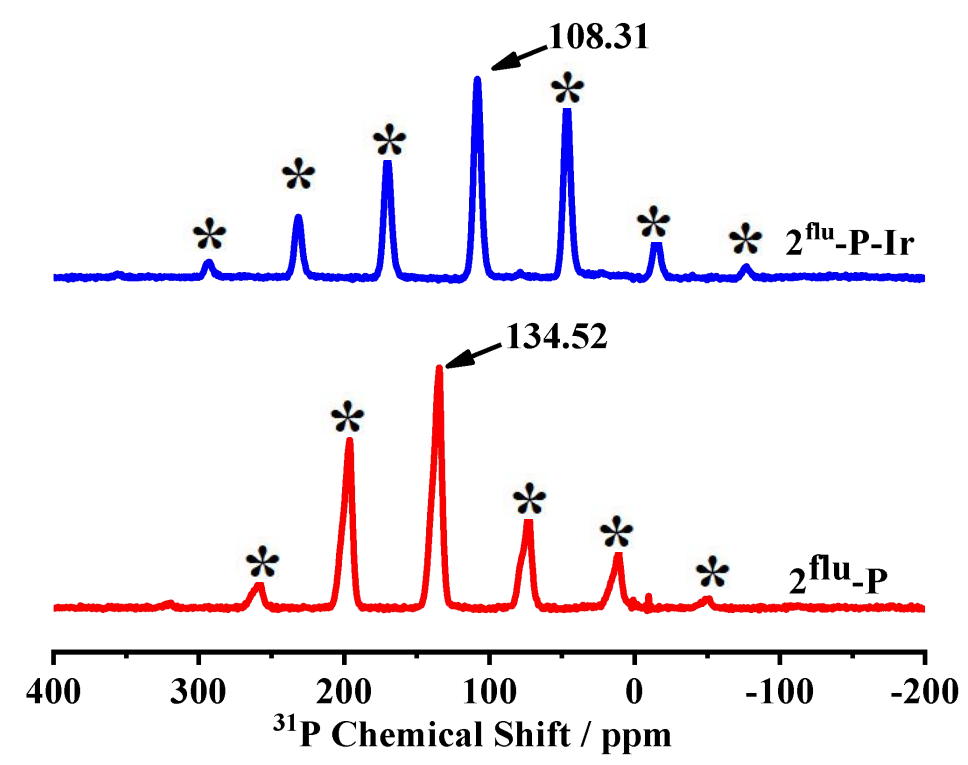

Note: The spinning side bands are labeled with asterisks. 
Figure S16. ${ }^{31} \mathrm{P}$ MAS NMR of $\mathbf{1}^{\text {ith }}$ post-modified with $\mathrm{P}\left(\mathrm{NMe}_{2}\right)_{3}$.

$\begin{array}{rllllllllllllll}400 & 360 & 320 & 280 & 240 & 200 & 160 & 120 & 80 & 40 & 0 & -20 & -60 & -100 & -160\end{array}$

Figure S17. ${ }^{31} \mathrm{P}$ MAS NMR of $2^{\text {ith }}$ post-modified with $\mathrm{P}\left(\mathrm{NMe}_{2}\right)_{3}$.

\begin{tabular}{rllllllllllllll}
\hline 400 & 360 & 320 & 280 & 240 & 200 & 160 & 120 & 80 & 40 & 0 & -20 & -60 & -100 & -160
\end{tabular}

Figure S18. ${ }^{31} \mathrm{P}$ MAS NMR of $3^{\text {ith }}$ post-modification with $\mathrm{P}\left(\mathrm{NMe}_{2}\right)_{3}$.

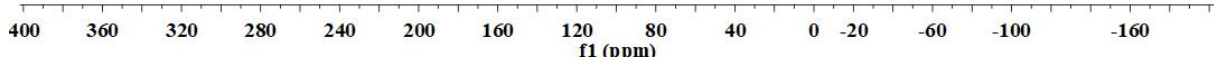


Figure S19. ${ }^{1} \mathrm{H}$ NMR of digested $\mathbf{1}^{\text {flu }}$

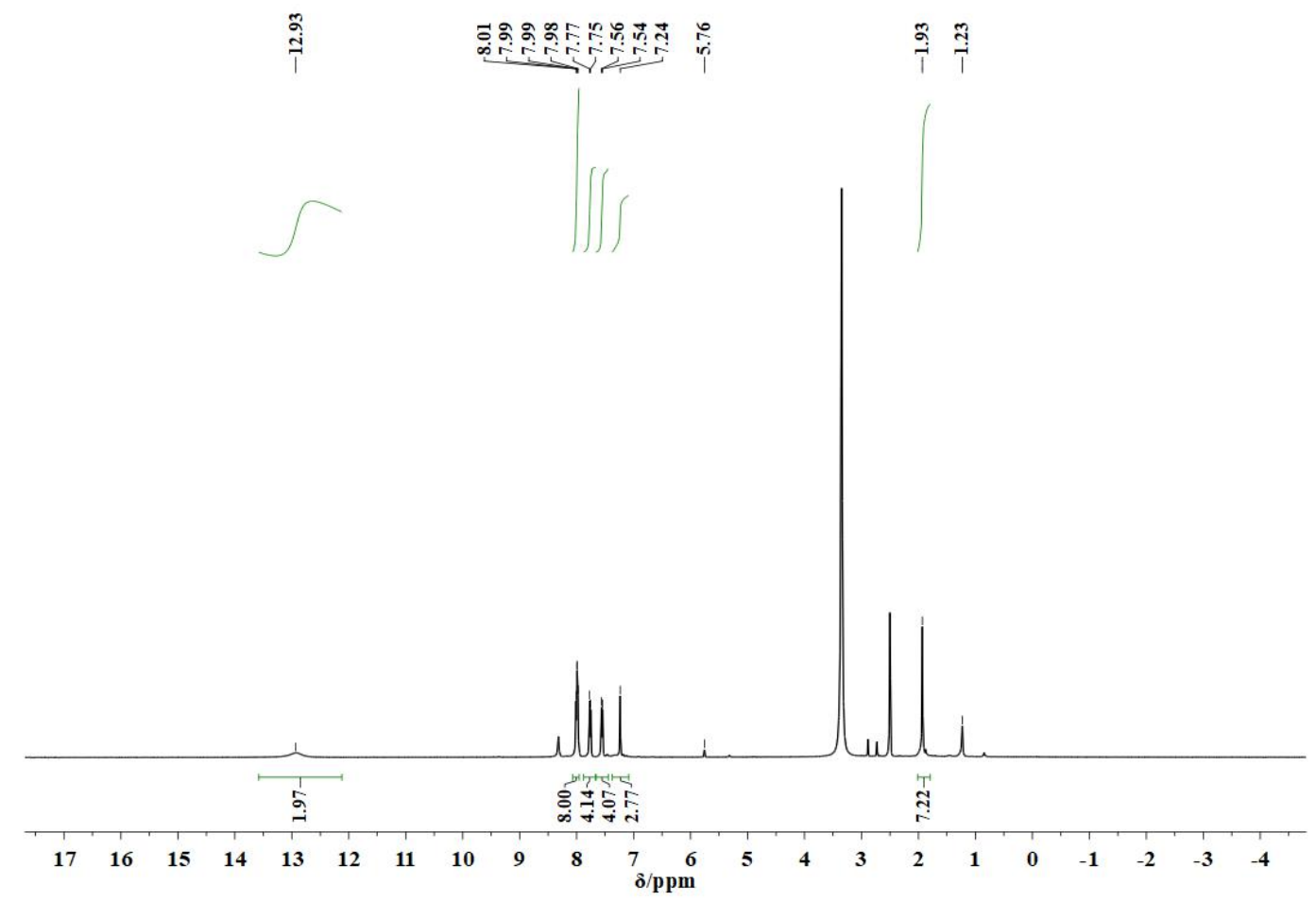

Figure S20. ${ }^{1} \mathrm{H}$ NMR of digested $\mathbf{1}^{\text {ith }}$

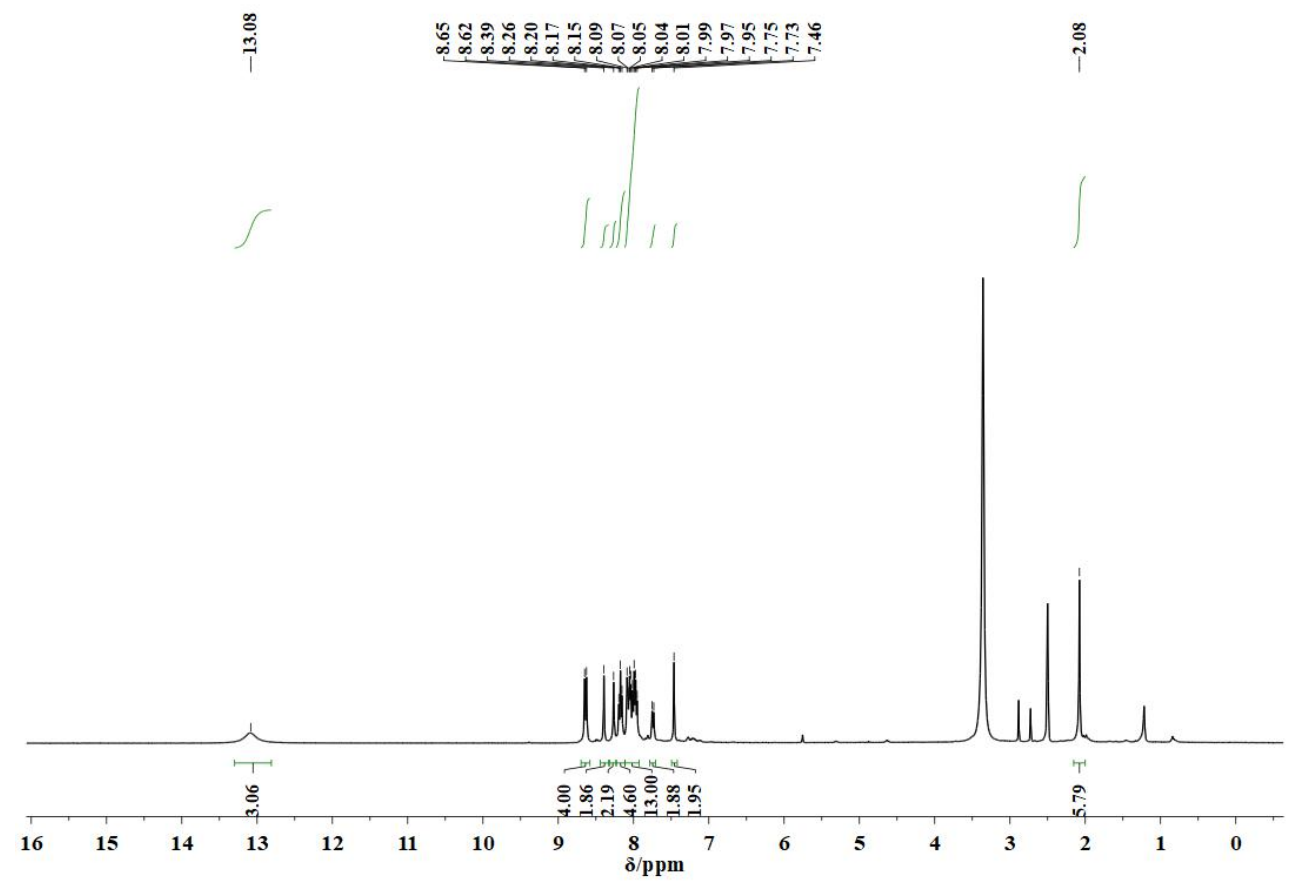


Figure S21. ${ }^{1} \mathrm{H}$ NMR of digested $\mathbf{2}^{\text {flu }}$

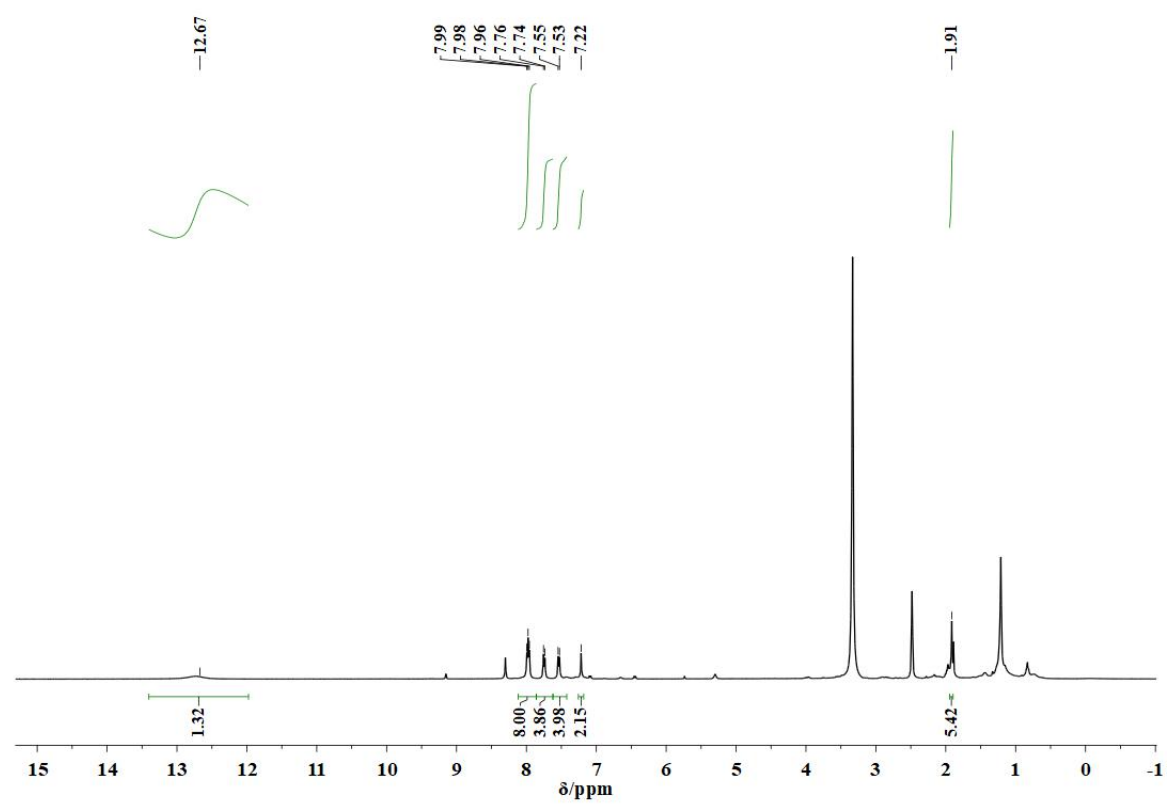

Figure S22. ${ }^{1} \mathrm{H}$ NMR of digested $\mathbf{2}^{\text {ith }}$

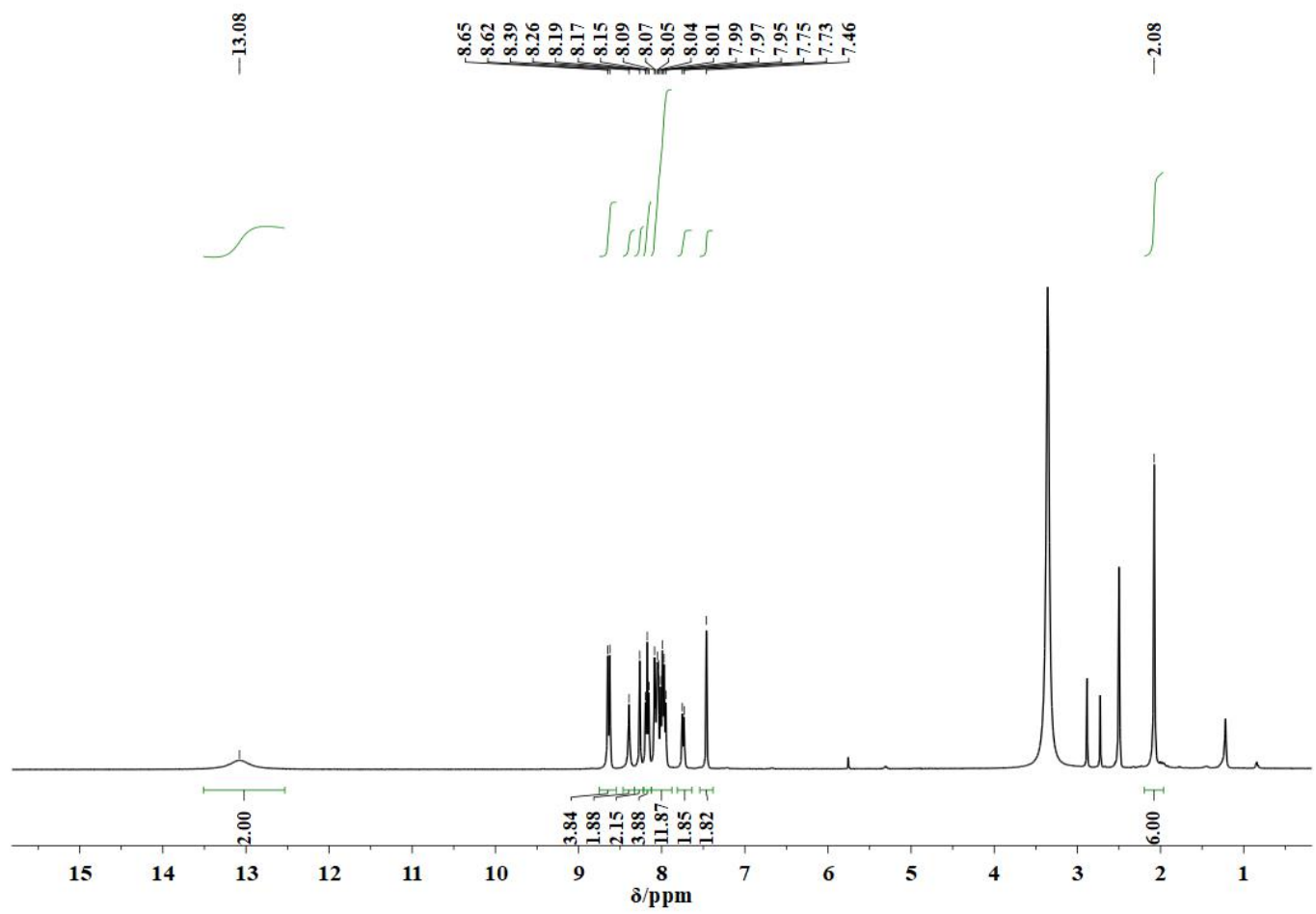


Figure S23. ${ }^{1} \mathrm{H}$ NMR of digested $3^{\text {ith }}$

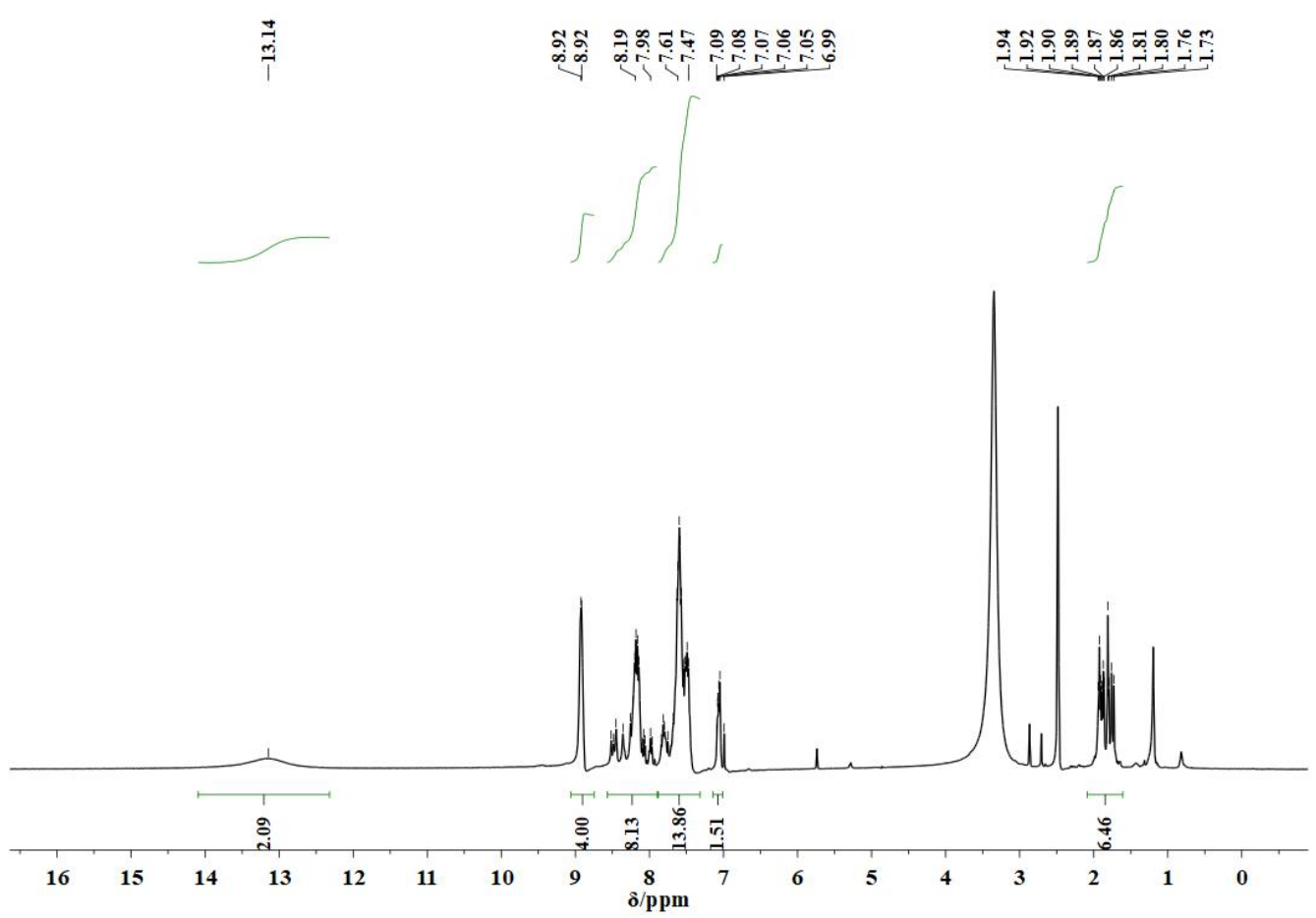

18. Figure S24 HPLC and NMR spectra of catalysis

18.1 Asymmetric hydrogenation reactions<smiles>COCC(=O)NC(Cc1ccccc1)C(=O)OC</smiles>

Enantiomeric excess was detemined by HPLC with a chiralcel OD-H column (hexane $/ i-\mathrm{PrOH}=$ $90 / 10,1.0 \mathrm{~mL} / \mathrm{min}) . \mathrm{t}_{\text {minor }}=9.488 \mathrm{~min}, \mathrm{t}_{\text {major }}=13.206 \mathrm{~min}$; ee $=98 \% .{ }^{1} \mathrm{H} \mathrm{NMR}\left(500 \mathrm{MHz}, \mathrm{CDCl}_{3}\right)$ $\delta 7.30-7.27(\mathrm{~m}, 3 \mathrm{H}), 7.11(\mathrm{~d}, J=5.5 \mathrm{~Hz}, 2 \mathrm{H}), 6.06(\mathrm{~s}, 1 \mathrm{H}), 4.90(\mathrm{dd}, J=5.6,2.0 \mathrm{~Hz}, 1 \mathrm{H}), 3.73(\mathrm{~s}$, $3 \mathrm{H}), 3.18-3.08(\mathrm{~m}, 1 \mathrm{H}), 1.99(\mathrm{~s}, 3 \mathrm{H})$.

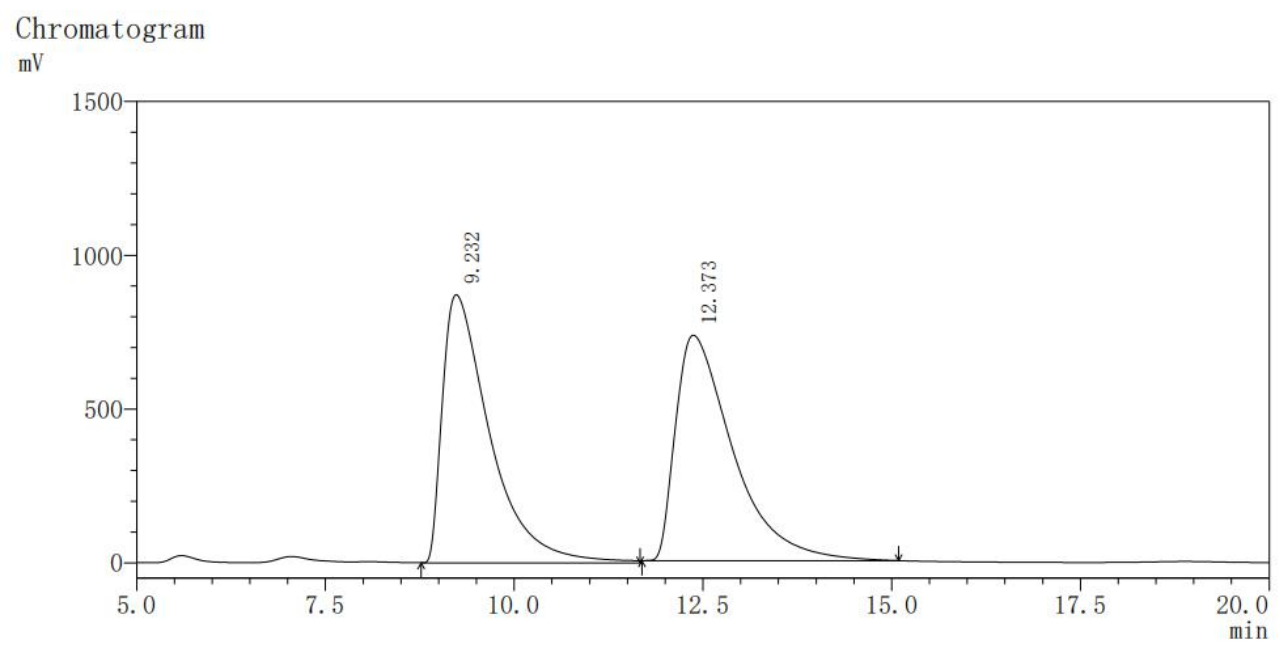




\begin{tabular}{|c|c|c|c|c|c|c|}
\hline \multicolumn{7}{|c|}{$20 \mathrm{~nm}$} \\
\hline ID\# & Start & End & Ret. Time & Height & Area & Area\% \\
\hline 1 & 8.767 & 11.667 & 9.232 & 871908 & 38149531 & 49.593 \\
\hline 2 & 11.692 & 15.092 & 12.373 & 733046 & 38776041 & 50.407 \\
\hline & & & & 1604954 & 76925572 & 100.000 \\
\hline
\end{tabular}

Chromatogram

$\mathrm{mV}$

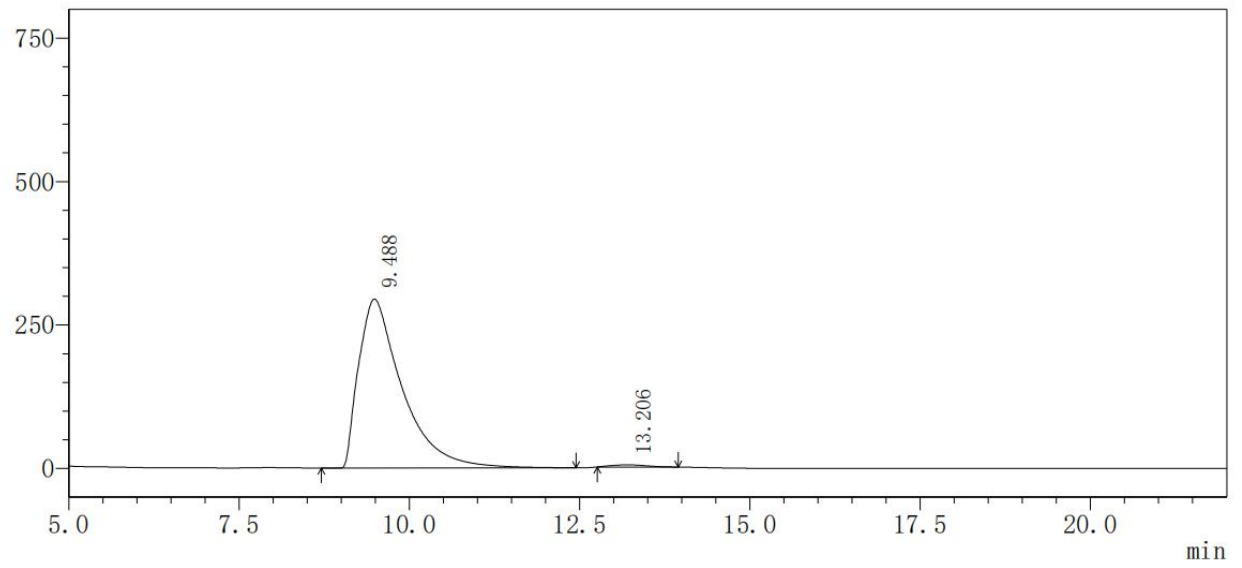

\begin{tabular}{|c|c|c|c|c|c|c|}
\hline \multicolumn{7}{|c|}{$220 \mathrm{~nm}$} \\
\hline ID\# & Start & End & Ret. Time & Height & Area & Area\% \\
\hline 1 & 8.708 & 12.450 & 9.488 & 294464 & 13100827 & 98.974 \\
\hline 2 & 12.758 & 13.950 & 13.206 & 3721 & 135752 & 1.026 \\
\hline & & & & 298185 & 13236579 & 100.000 \\
\hline
\end{tabular}

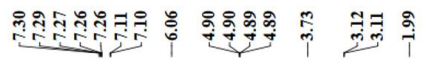
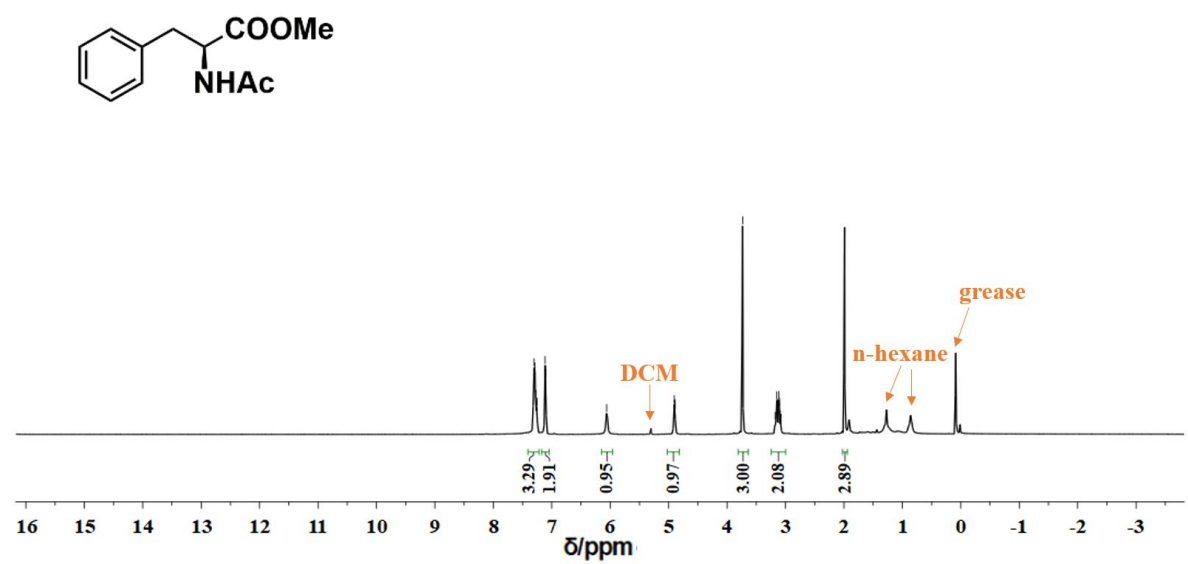<smiles>COC(=O)C(Cc1cccc(OC)c1)NC(C)=O</smiles>

Enantiomeric excess was detemined by HPLC with a chiralcel OD-H column (hexane $/ i-\mathrm{PrOH}=$ $90 / 10,1.0 \mathrm{~mL} / \mathrm{min}) . \mathrm{t}_{\operatorname{minor}}=11.538 \mathrm{~min}, \mathrm{t}_{\text {major }}=15.242 \mathrm{~min}$; ee $=98 \% .{ }^{1} \mathrm{H}$ NMR $(500 \mathrm{MHz}$, $\left.\mathrm{CDCl}_{3}\right) \delta 7.21(\mathrm{t}, J=7.9 \mathrm{~Hz}, 1 \mathrm{H}), 6.80(\mathrm{dd}, J=8.1,2.2 \mathrm{~Hz}, 1 \mathrm{H}), 6.69(\mathrm{~d}, J=7.6 \mathrm{~Hz}, 1 \mathrm{H}), 6.65(\mathrm{~m}$, 
$1 \mathrm{H}), 6.04(\mathrm{~d}, J=7.3 \mathrm{~Hz}, 1 \mathrm{H}), 4.91-4.87(\mathrm{~m}, 1 \mathrm{H}), 3.79(\mathrm{~s}, 3 \mathrm{H}), 3.74(\mathrm{~s}, 3 \mathrm{H}), 3.10(\mathrm{qd}, J=13.9,5.8$ $\mathrm{Hz}, 2 \mathrm{H}), 2.00$ (s, 3H).

Chromatogram $\mathrm{mV}$

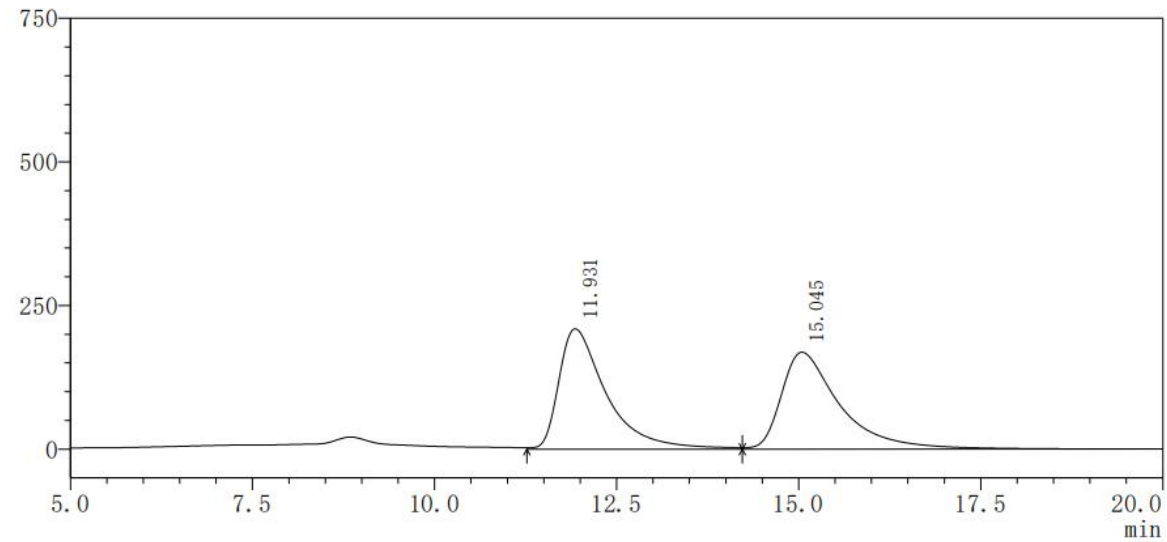

\begin{tabular}{r|r|r|r|r|r|r|}
\hline \multicolumn{1}{|c|}{ ID\# } & Start & \multicolumn{1}{l|}{ End } & Ret. Time & Height & \multicolumn{1}{c|}{ Area } & Area\% \\
\hline 1 & 11.267 & 14.225 & 11.931 & 209585 & 9542682 & 50.112 \\
\hline 2 & 14.225 & 21.017 & 15.045 & 168768 & 9500173 & 49.888 \\
\hline & & & & 378353 & 19042855 & 100.000 \\
\hline
\end{tabular}

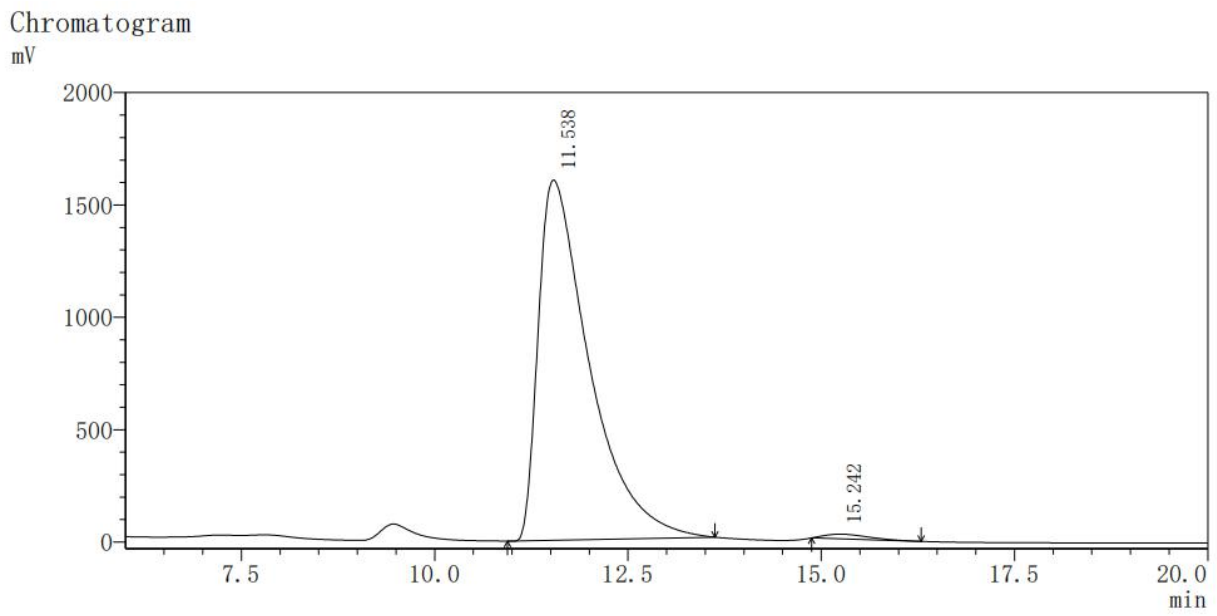

\begin{tabular}{|r|r|r|r|r|r|r|}
\hline ID\# & Start & End & Ret. Time & \multicolumn{1}{|c|}{ Height } & Area & Area\% \\
\hline 1 & 10.942 & 13.625 & 11.538 & 1602307 & 73738199 & 98.896 \\
\hline 2 & 14.875 & 16.292 & 15.242 & 20803 & 822856 & 1.104 \\
\hline & & & & 1623110 & 74561055 & 100.000 \\
\hline
\end{tabular}




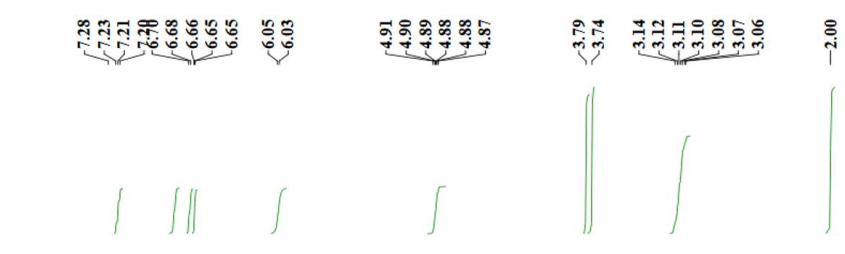

If COOMe

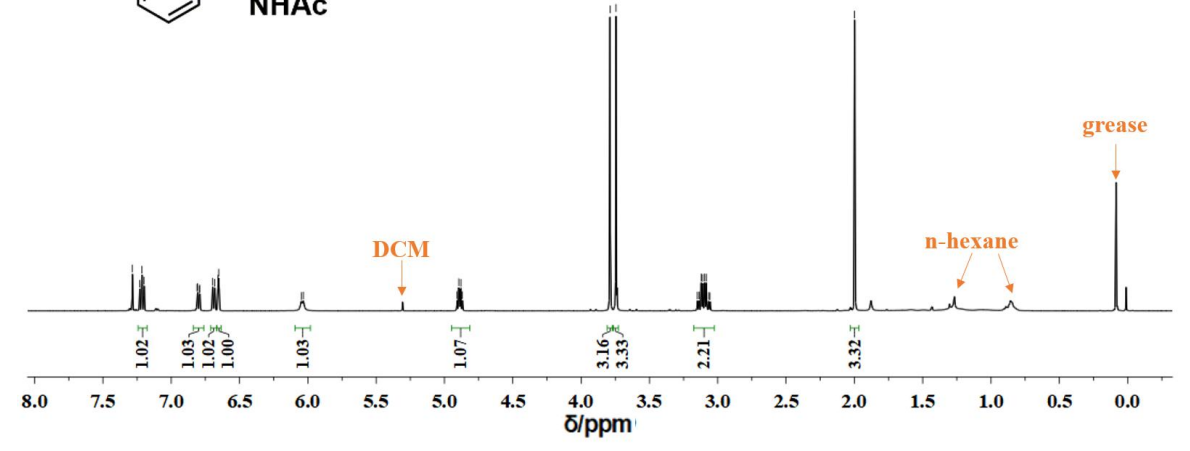

$\underbrace{O}_{\mathrm{O}_{0}}$

Enantiomeric excess was detemined by HPLC with a chiralcel OD-H column (hexane $/ i-\mathrm{PrOH}=$ $90 / 10,1.0 \mathrm{~mL} / \mathrm{min}) . \mathrm{t}_{\text {minor }}=10.095 \mathrm{~min}, \mathrm{t}_{\text {major }}=12.398 \mathrm{~min}$; ee $=92 \% .{ }^{1} \mathrm{H}$ NMR $(400 \mathrm{MHz}$, $\left.\mathrm{CDCl}_{3}\right) \delta 7.38(\mathrm{~d}, J=7.9 \mathrm{~Hz}, 1 \mathrm{H}), 7.24(\mathrm{~s}, 1 \mathrm{H}), 7.16(\mathrm{t}, J=7.8 \mathrm{~Hz}, 1 \mathrm{H}), 7.02(\mathrm{~d}, J=7.6 \mathrm{~Hz}, 1 \mathrm{H})$, $6.01(\mathrm{~d}, J=6.1 \mathrm{~Hz}, 1 \mathrm{H}), 4.86(\mathrm{dd}, J=13.3,5.8 \mathrm{~Hz}, 1 \mathrm{H}), 3.73$ (s, 3H), 3.08 (ddd, $J=32.3,13.8$, $5.7 \mathrm{~Hz}, 2 \mathrm{H}), 2.00(\mathrm{~s}, 3 \mathrm{H})$.

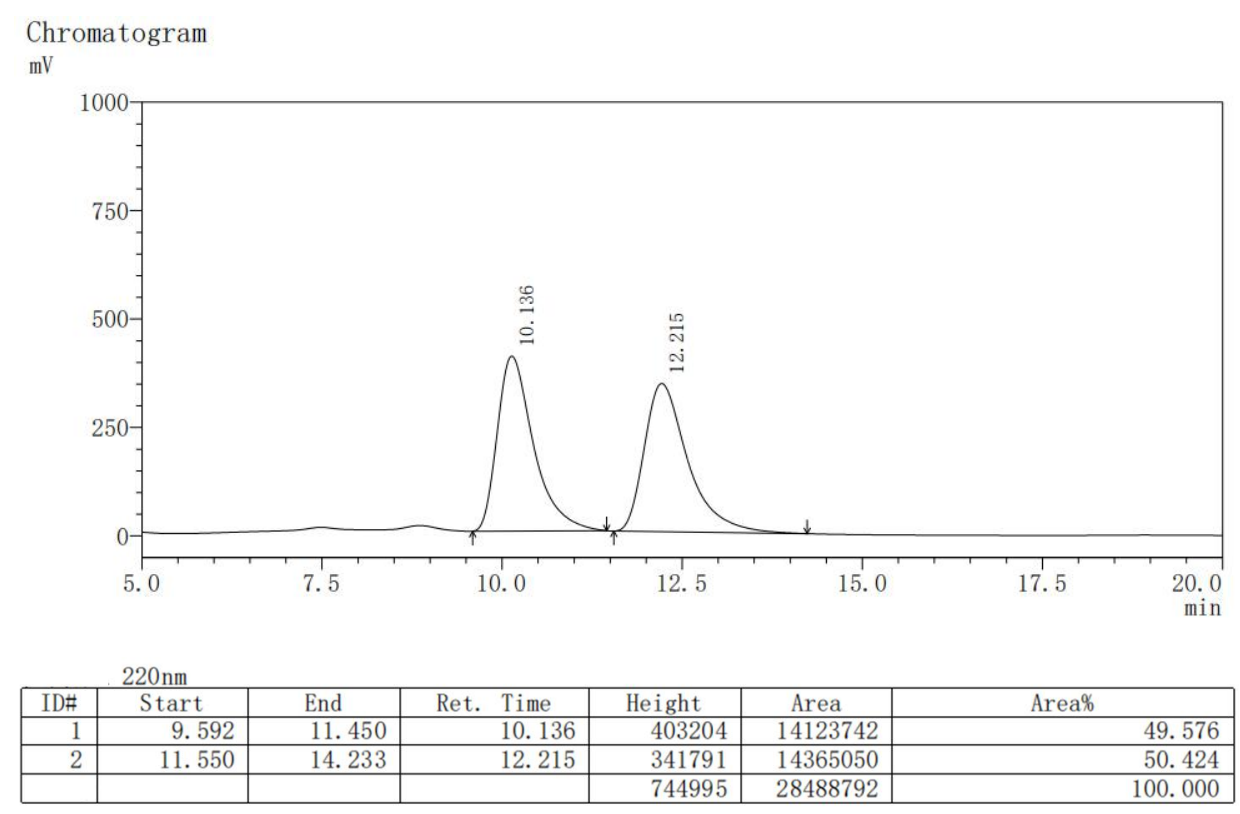




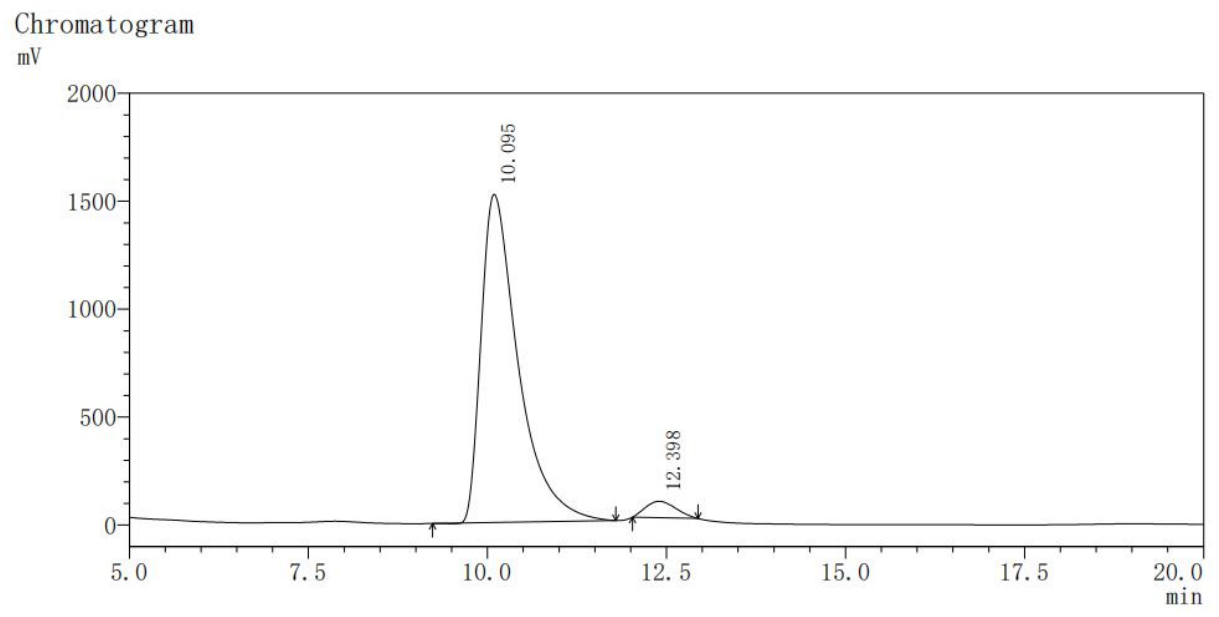

\begin{tabular}{|r|r|r|r|r|r|r|}
\hline ID\# & \multicolumn{1}{|c|}{ Start } & End & \multicolumn{1}{c|}{ Ret. Time } & \multicolumn{1}{c|}{ Height } & \multicolumn{1}{c|}{ Area } & \multicolumn{1}{|c|}{ Area\% } \\
\hline 1 & 9.233 & 11.792 & 10.095 & 1520233 & 54925934 & 96.095 \\
\hline 2 & 12.025 & 12.942 & 12.398 & 75926 & 2232210 & 3.905 \\
\hline & & & & 1596159 & 57158144 & 100.000 \\
\hline
\end{tabular}
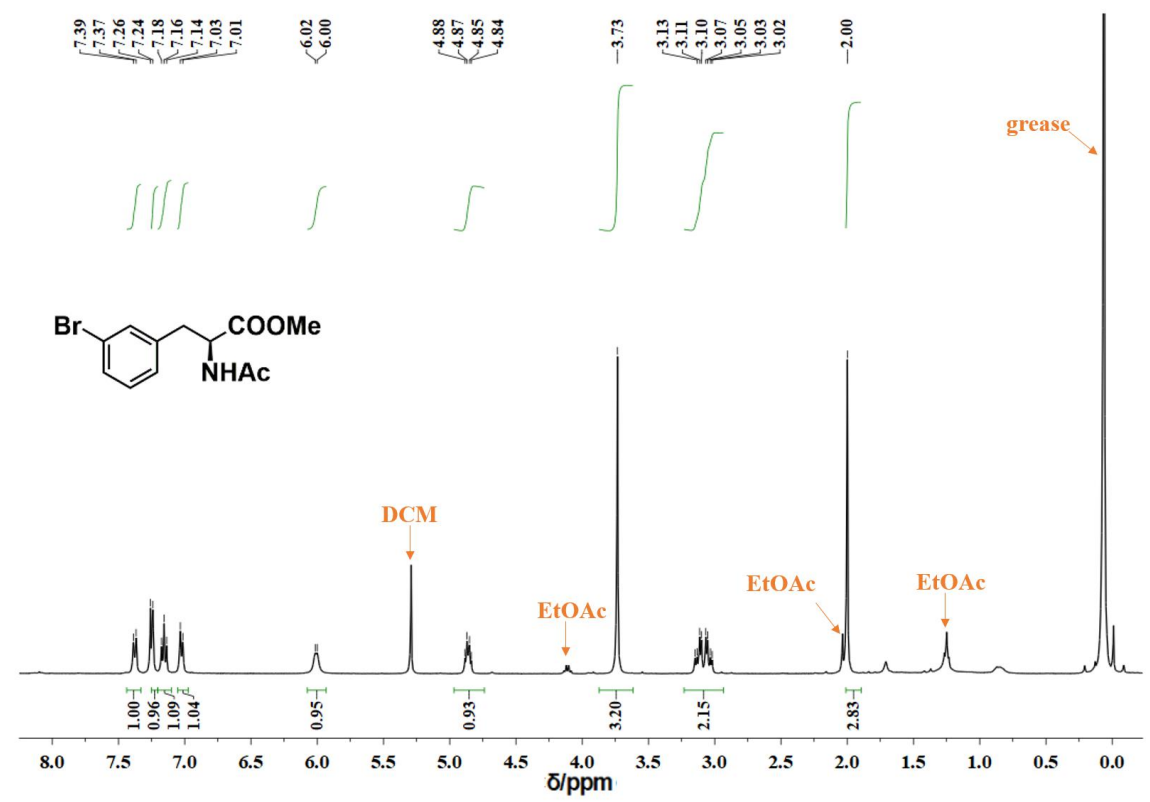<smiles>COC(=O)C(Cc1ccc(OC)cc1)NC(C)=O</smiles>

Enantiomeric excess was detemined by HPLC with a chiralcel OD-H column (hexane $/ i-\mathrm{PrOH}=$ $90 / 10,1.0 \mathrm{~mL} / \mathrm{min}) . \mathrm{t}_{\text {minor }}=11.773 \mathrm{~min}, \mathrm{t}_{\text {major }}=15.955 \mathrm{~min}$; ee $=97 \% .{ }^{1} \mathrm{H}$ NMR $(500 \mathrm{MHz}$, $\left.\mathrm{CDCl}_{3}\right) \delta 7.02(\mathrm{~d}, J=8.6 \mathrm{~Hz}, 2 \mathrm{H}), 6.84(\mathrm{~d}, J=8.7 \mathrm{~Hz}, 2 \mathrm{H}), 5.99(\mathrm{~d}, J=7.4 \mathrm{~Hz}, 1 \mathrm{H}), 4.87-4.83(\mathrm{~m}$, 1H) $3.79(\mathrm{~s}, 3 \mathrm{H}), 3.74(\mathrm{~s}, 3 \mathrm{H}), 3.07(\mathrm{qd}, J=14.0,5.7 \mathrm{~Hz}, 1 \mathrm{H}), 2.00(\mathrm{~s}, 3 \mathrm{H})$. 
Chromatogram

$\mathrm{mV}$

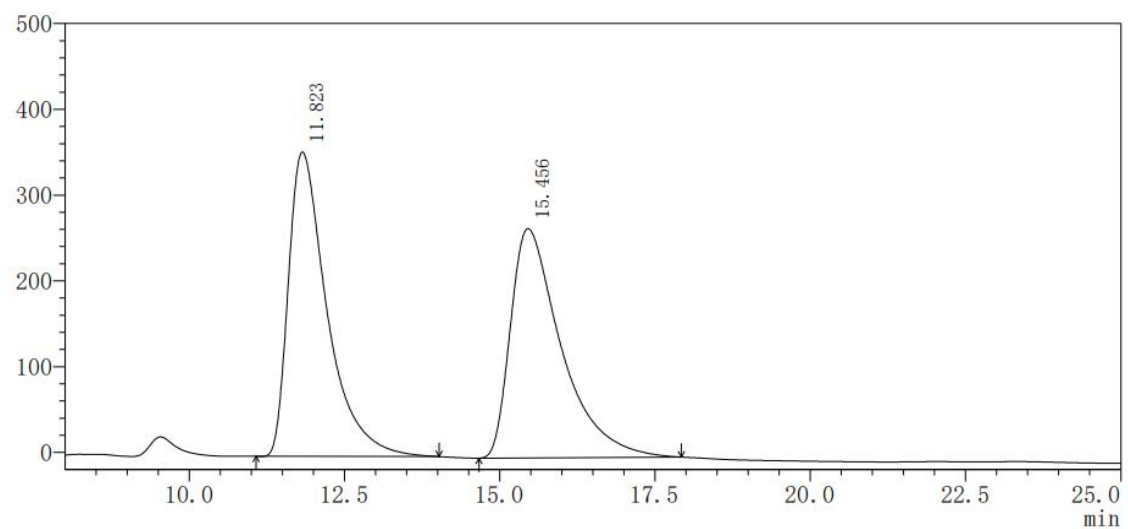

$220 \mathrm{~nm}$

\begin{tabular}{|r|r|r|r|r|r|r|}
\hline ID\# & Start & End & Ret. Time & Height & Area & Area\% \\
\hline 1 & 11.075 & 14.025 & 11.823 & 354955 & 15351624 & 50.289 \\
\hline 2 & 14.667 & 17.925 & 15.456 & 267295 & 15174924 & 49.711 \\
\hline & & & & 622250 & 30526547 & 100.000 \\
\hline
\end{tabular}

Chromatogram

$\mathrm{mV}$

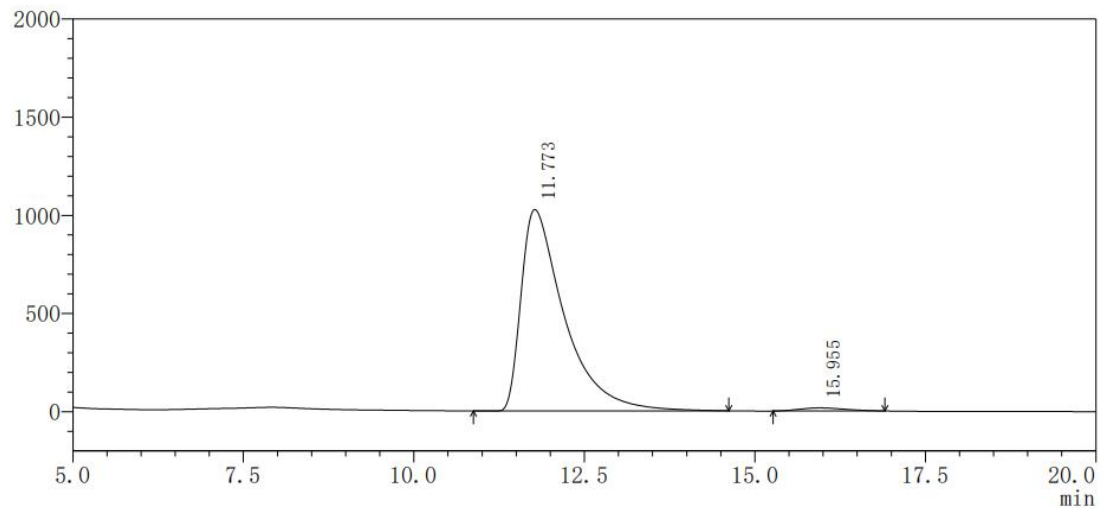

$220 \mathrm{~nm}$

\begin{tabular}{|r|c|r|r|r|r|r|}
\hline ID\# & Start & \multicolumn{1}{|c|}{ End } & \multicolumn{1}{c|}{ Ret. Time } & \multicolumn{1}{c|}{ Height } & \multicolumn{1}{c|}{ Area } & \multicolumn{1}{c|}{ Area\% } \\
\hline 1 & 10.875 & 14.617 & 11.773 & 1026008 & 45315775 & 98.406 \\
\hline 2 & 15.267 & 16.908 & 15.955 & 15812 & 733854 & 1.594 \\
\hline & & & & 1041819 & 46049628 & 100.000 \\
\hline
\end{tabular}



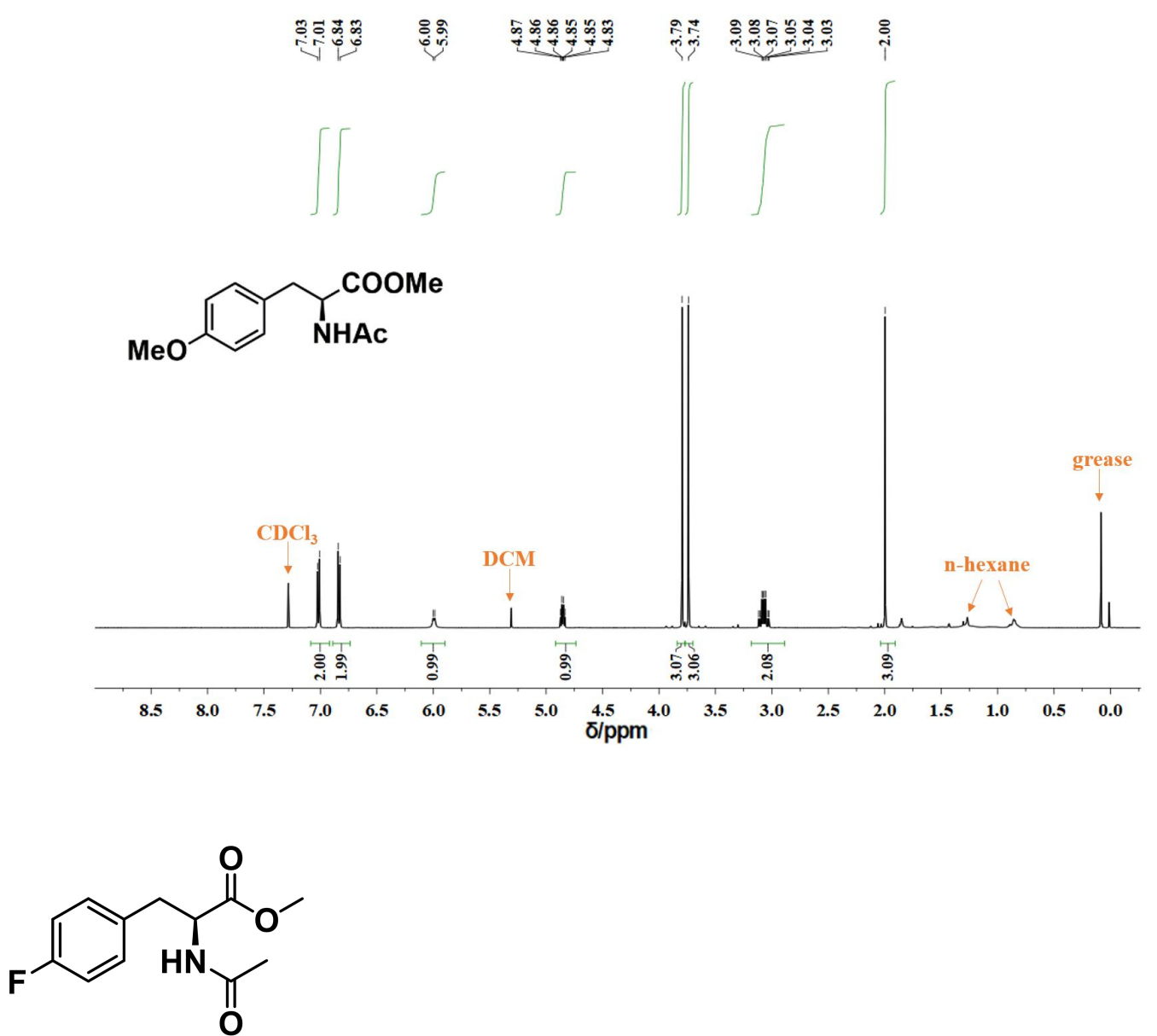

Enantiomeric excess was detemined by HPLC with a chiralcel OD-H column (hexane $/ i-\mathrm{PrOH}=$ 90/10, $1.0 \mathrm{~mL} / \mathrm{min}) . \mathrm{t}_{\text {minor }}=10.080 \mathrm{~min}$, $\mathrm{t}_{\text {major }}=13.516 \mathrm{~min}$; ee $=96 \% .{ }^{1} \mathrm{H} \mathrm{NMR}\left(400 \mathrm{MHz}, \mathrm{CDCl}_{3}\right)$ $\delta 7.01(\mathrm{dt}, J=33.0,8.5 \mathrm{~Hz}, 4 \mathrm{H}), 5.95(\mathrm{~s}, 1 \mathrm{H}), 4.86(\mathrm{dd}, J=13.3,5.7 \mathrm{~Hz}, 1 \mathrm{H}), 3.72(\mathrm{~s}, 3 \mathrm{H}), 3.09$ (qd, $J=13.9,5.5 \mathrm{~Hz}, 1 \mathrm{H}), 1.99(\mathrm{~s}, 3 \mathrm{H})$.

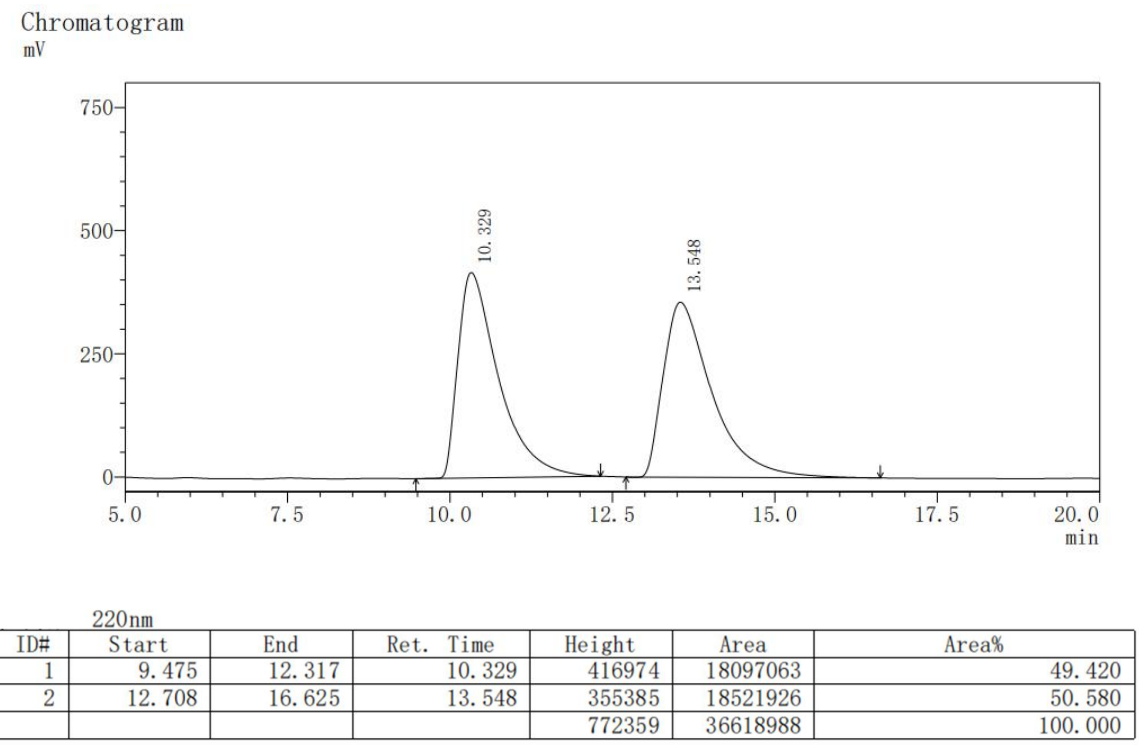


Chromatogram

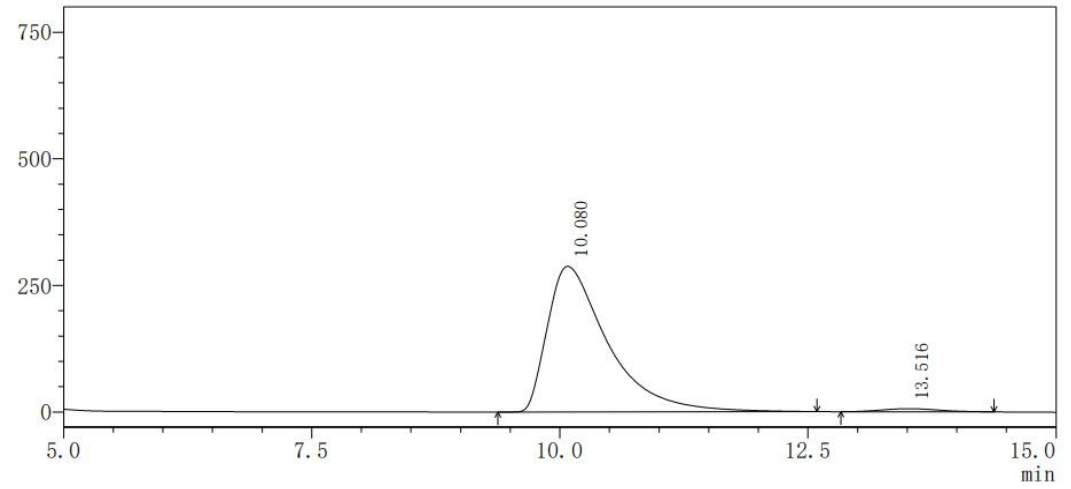

\begin{tabular}{|r|r|r|r|r|r|r|}
\hline ID\# & \multicolumn{1}{|c|}{ Start } & \multicolumn{1}{|c|}{ End } & \multicolumn{1}{|c|}{ Ret. Time } & Height & \multicolumn{1}{c|}{ Area } & Area\% \\
\hline 1 & 9.375 & 12.592 & 10.080 & 287557 & 12215245 & 98.031 \\
\hline 2 & 12.833 & 14.375 & 13.516 & 6110 & 245380 & 1.969 \\
\hline & & & & 293667 & 12460625 & 100.000 \\
\hline
\end{tabular}
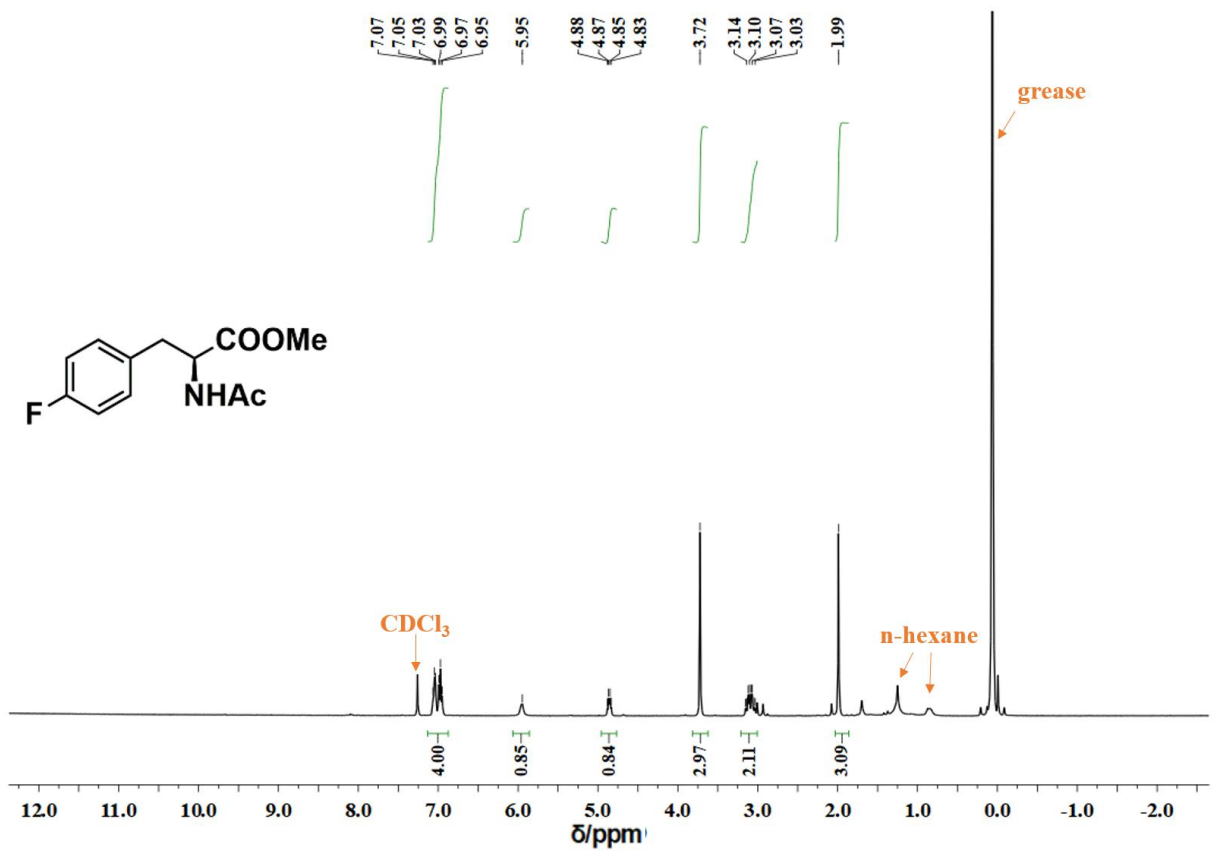<smiles>COC(=O)C(Cc1ccccc1F)NC(C)=O</smiles>

Enantiomeric excess was detemined by HPLC with a chiralcel OD-H column (hexane $/ i-\mathrm{PrOH}=$ $90 / 10,1.0 \mathrm{~mL} / \mathrm{min}) . \mathrm{t}_{\text {minor }}=10.565 \mathrm{~min}, \mathrm{t}_{\text {major }}=15.473 \mathrm{~min}$; ee $=95 \% .{ }^{1} \mathrm{H}$ NMR $(400 \mathrm{MHz}$, $\left.\mathrm{CDCl}_{3}\right) \delta 7.41(\mathrm{~d}, J=8.2 \mathrm{~Hz}, 2 \mathrm{H}), 6.96(\mathrm{~d}, J=8.1 \mathrm{~Hz}, 2 \mathrm{H}), 5.89(\mathrm{~s}, 1 \mathrm{H}), 4.87(\mathrm{~d}, J=7.0 \mathrm{~Hz}, 1 \mathrm{H})$, 3.73 (s, 3H), 3.09 (ddd, $J=19.2,13.9,5.8 \mathrm{~Hz}, 2 \mathrm{H}), 2.00$ (s, 3H). 
Chromatogram

$\mathrm{mV}$

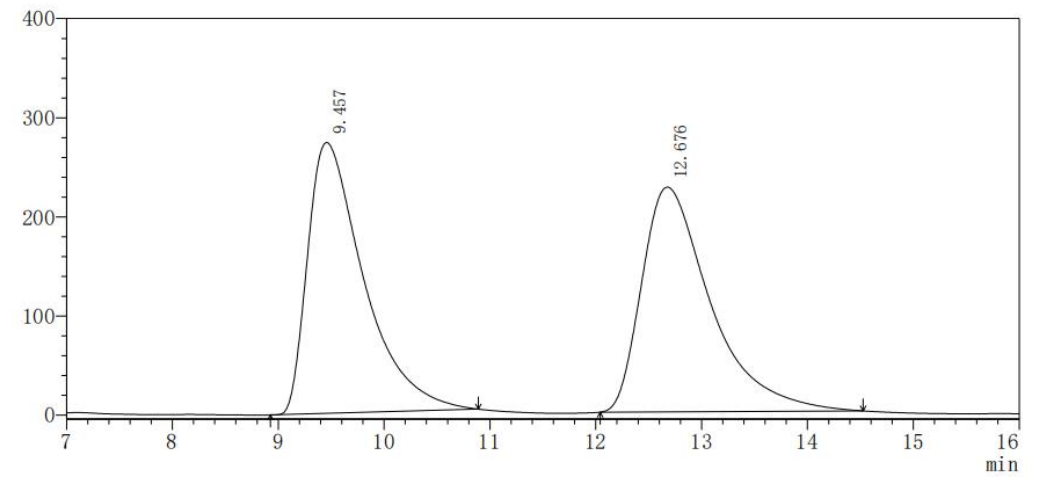

\begin{tabular}{|r|r|r|r|r|r|r|}
\hline ID\# & \multicolumn{1}{|c|}{ Start } & \multicolumn{1}{c|}{ End } & Ret. Time & Height & Area & Area\% \\
\hline 1 & 8.925 & 10.892 & 9.457 & 273230 & 10077295 & 49.570 \\
\hline 2 & 12.042 & 14.525 & 12.676 & 226619 & 10252082 & 50.430 \\
\hline & & & & 499848 & 20329377 & 100.000 \\
\hline
\end{tabular}

Chromatogram

$\mathrm{mV}$

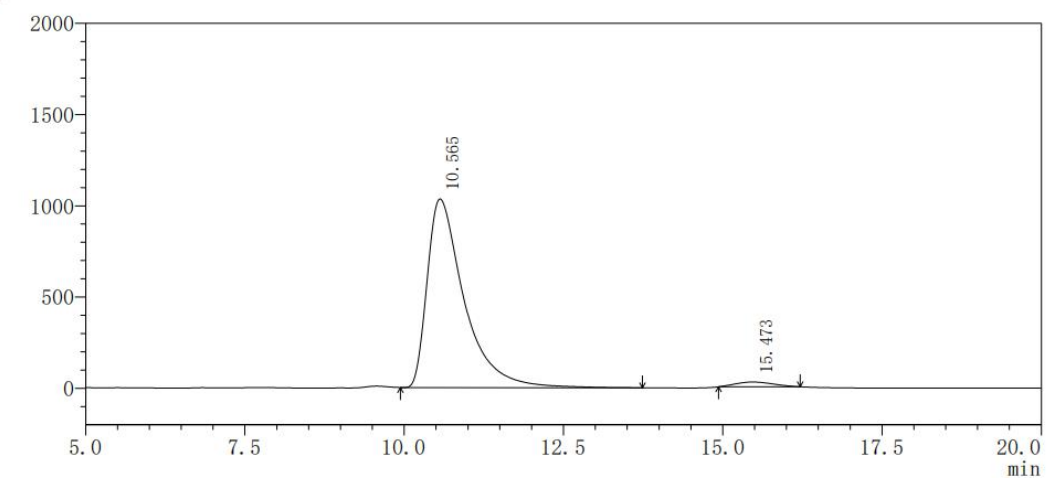

\begin{tabular}{|r|r|r|r|r|r|r|}
\hline \multicolumn{1}{|c|}{$220 \mathrm{~nm}$} \\
\hline 1 & Start & \multicolumn{1}{|c|}{ End } & Ret. Time & \multicolumn{1}{c|}{ Height } & \multicolumn{1}{c|}{ Area } & Area\% \\
\hline 2 & 9.942 & 13.742 & 10.565 & 1034181 & 41691350 & 97.490 \\
\hline & 14.933 & 16.217 & 15.473 & 26094 & 1073295 & 2.510 \\
\hline
\end{tabular}
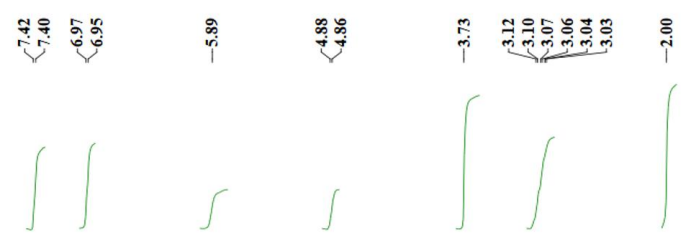

(1)

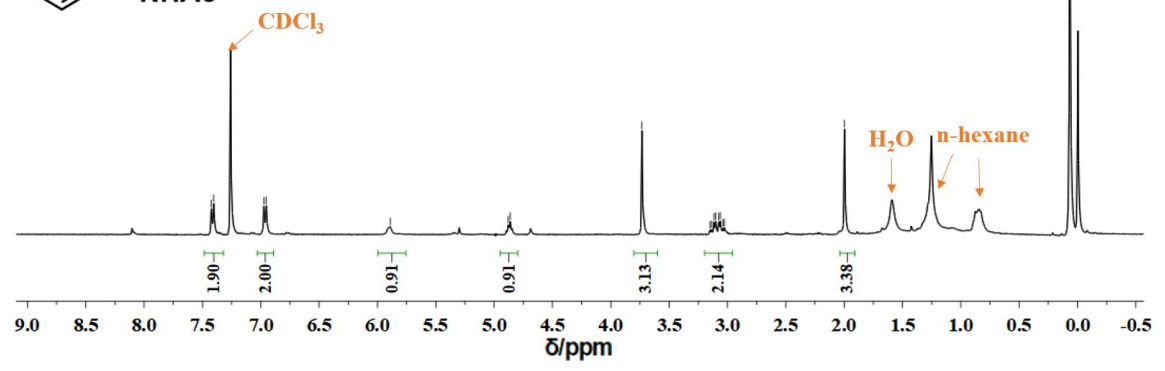


<smiles>COC(=O)C(Cc1ccccc1OC)NC(C)=O</smiles>

Enantiomeric excess was detemined by HPLC with a chiralcel OD-H column (hexane $/ i$-PrOH $=$ $90 / 10,1.0 \mathrm{~mL} / \mathrm{min}) . \mathrm{t}_{\text {minor }}=12.852 \mathrm{~min}, \mathrm{t}_{\text {major }}=28.234 \mathrm{~min}$; ee $=95 \% .{ }^{1} \mathrm{H}$ NMR $(400 \mathrm{MHz}$, $\left.\mathrm{CDCl}_{3}\right) \delta 7.23(\mathrm{~d}, J=6.7 \mathrm{~Hz}, 1 \mathrm{H}), 7.07(\mathrm{~d}, J=6.7 \mathrm{~Hz}, 1 \mathrm{H}), 6.88(\mathrm{dd}, J=15.2,7.8 \mathrm{~Hz}, 2 \mathrm{H}), 6.24$ (s, 1H), $4.74(\mathrm{q}, J=6.7 \mathrm{~Hz}, 1 \mathrm{H}), 3.84(\mathrm{~s}, 3 \mathrm{H}), 3.71(\mathrm{~s}, 3 \mathrm{H}), 3.10(\mathrm{~d}, J=6.4 \mathrm{~Hz}, 2 \mathrm{H}), 1.93(\mathrm{~s}, 3 \mathrm{H})$.

Chromatogram

$$
\mathrm{mV}
$$
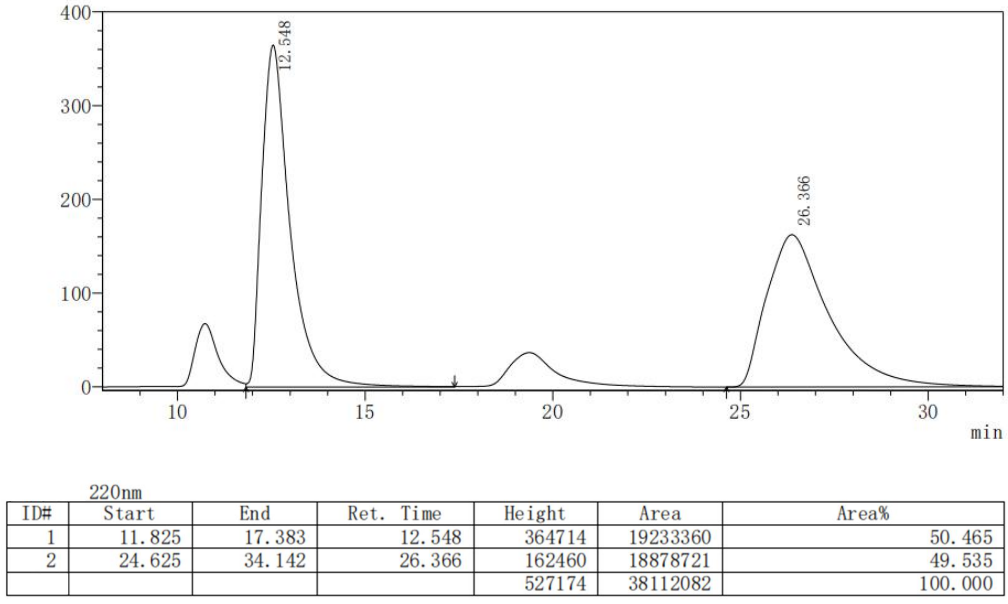

\section{Chromatogram}

$\mathrm{mV}$

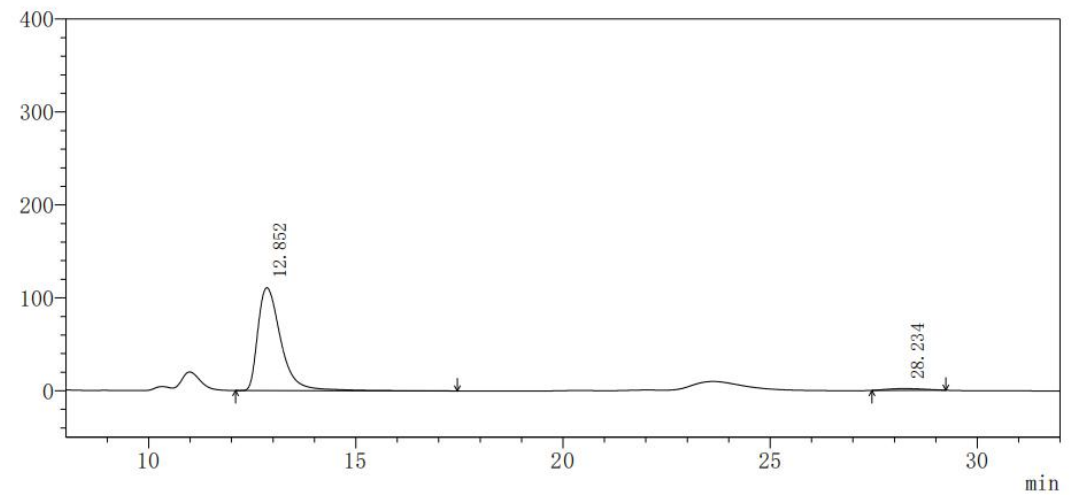

\begin{tabular}{|r|c|r|r|r|r|r|}
\hline ID\# & \multicolumn{1}{|c|}{ Start } & \multicolumn{1}{c|}{ End } & \multicolumn{1}{c|}{ Ret. Time } & \multicolumn{1}{c|}{ Height } & \multicolumn{1}{c|}{ Area } & Area\% \\
\hline 1 & 12.100 & 17.450 & 12.852 & 110807 & 4273328 & 97.397 \\
\hline 2 & 27.458 & 29.242 & 28.234 & 1849 & 114185 & 2.603 \\
\hline & & & & 112656 & 4387514 & 100.000 \\
\hline
\end{tabular}



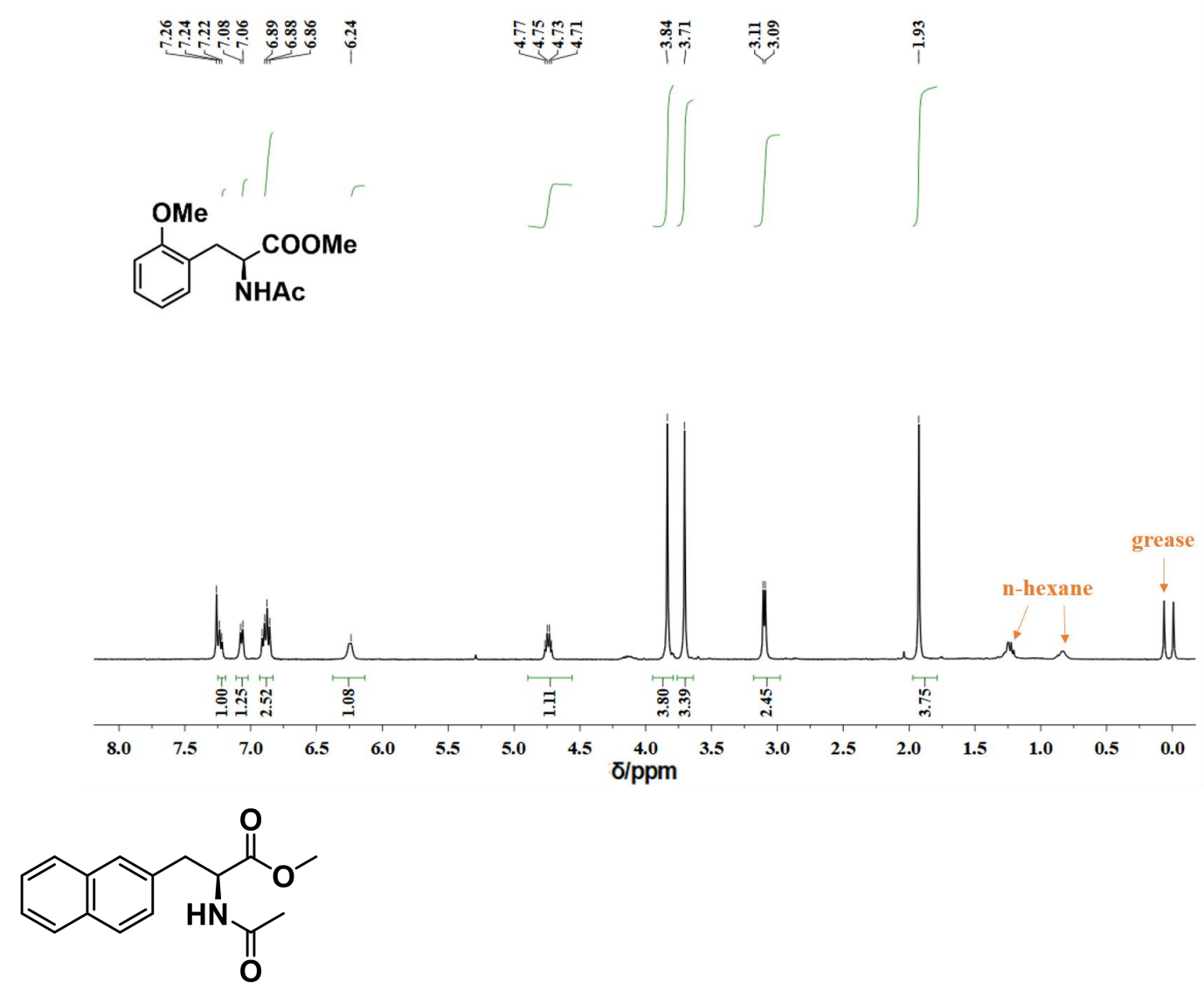

Enantiomeric excess was detemined by HPLC with a chiralcel OD-H column (hexane $/ i-\mathrm{PrOH}=$ $90 / 10,1.0 \mathrm{~mL} / \mathrm{min}) . \mathrm{t}_{\text {minor }}=12.804 \mathrm{~min}, \mathrm{t}_{\text {major }}=16.142 \mathrm{~min}$; ee $=96 \% .{ }^{1} \mathrm{H} \mathrm{NMR}(400 \mathrm{MHz}$, $\left.\mathrm{CDCl}_{3}\right) \delta 7.79(\mathrm{dd}, J=13.8,8.7 \mathrm{~Hz}, 1 \mathrm{H}), 7.56(\mathrm{~s}, 1 \mathrm{H}), 7.47-7.46(\mathrm{~m}, 2 \mathrm{H}), 7.22(\mathrm{~d}, J=8.3 \mathrm{~Hz}, 1 \mathrm{H})$, $6.03(\mathrm{~d}, J=7.0 \mathrm{~Hz}, 1 \mathrm{H}), 4.97(\mathrm{dd}, J=13.4,5.9 \mathrm{~Hz}, 1 \mathrm{H}), 3.73(\mathrm{~s}, 3 \mathrm{H}), 3.28(\mathrm{qd}, J=13.9,5.8 \mathrm{~Hz}$, $2 \mathrm{H}), 1.97(\mathrm{~s}, 3 \mathrm{H})$.

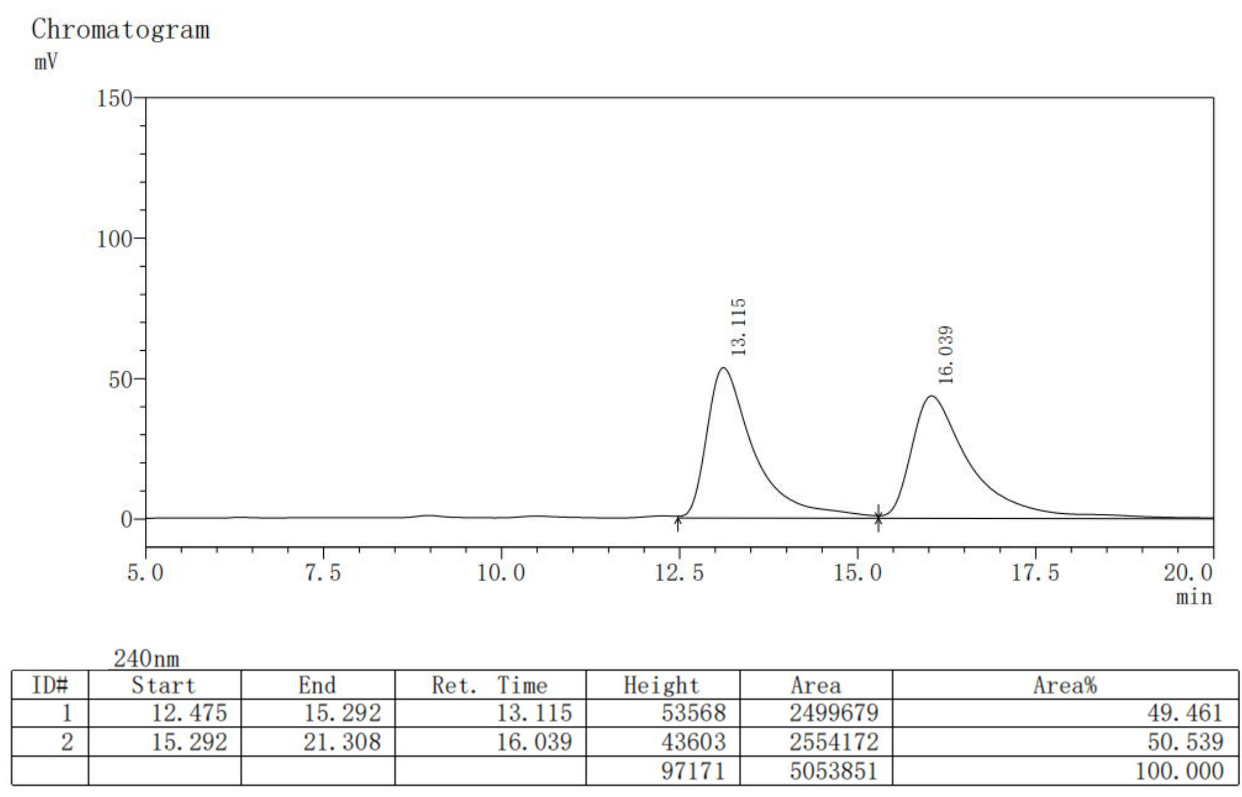




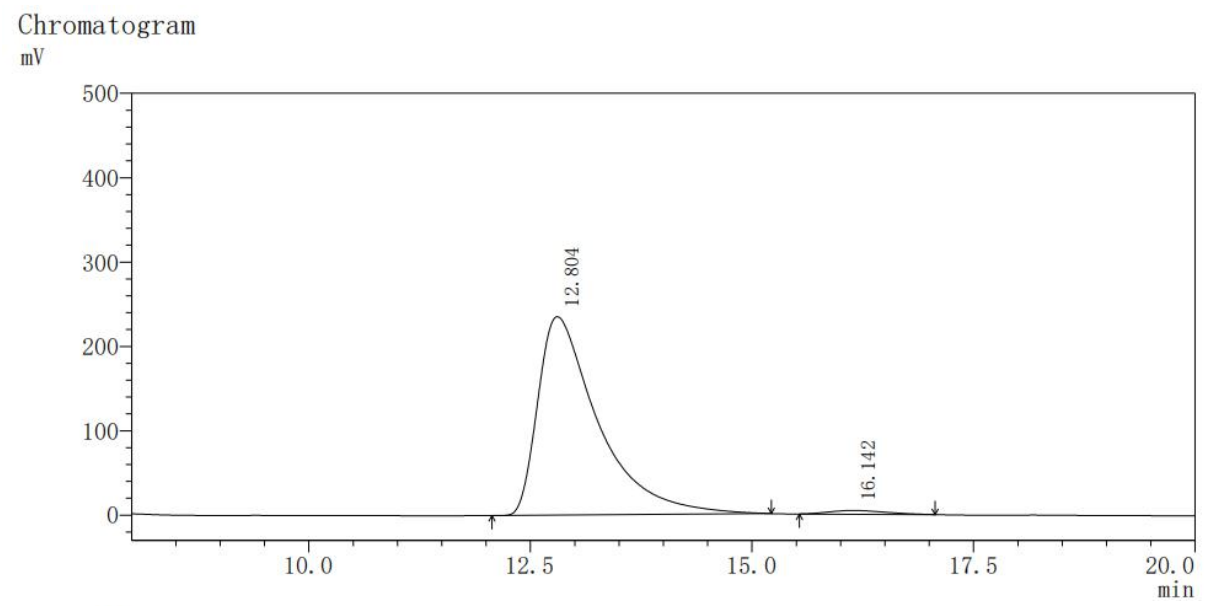

\begin{tabular}{|r|r|r|r|r|r|r|}
\hline ID\# & \multicolumn{1}{|c|}{ Start } & \multicolumn{1}{c|}{ End } & \multicolumn{1}{c|}{ Ret. Time } & \multicolumn{1}{c|}{ Height } & \multicolumn{1}{c|}{ Area } & \multicolumn{1}{c|}{ Area\% } \\
\hline 1 & 12.067 & 15.217 & 12.804 & 235197 & 11130767 & 98.270 \\
\hline 2 & 15.533 & 17.067 & 16.142 & 4402 & 195915 & 1.730 \\
\hline & & & & 239599 & 11326682 & 100.000 \\
\hline
\end{tabular}

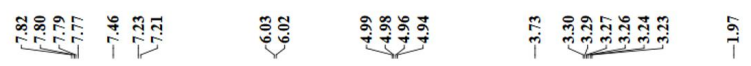
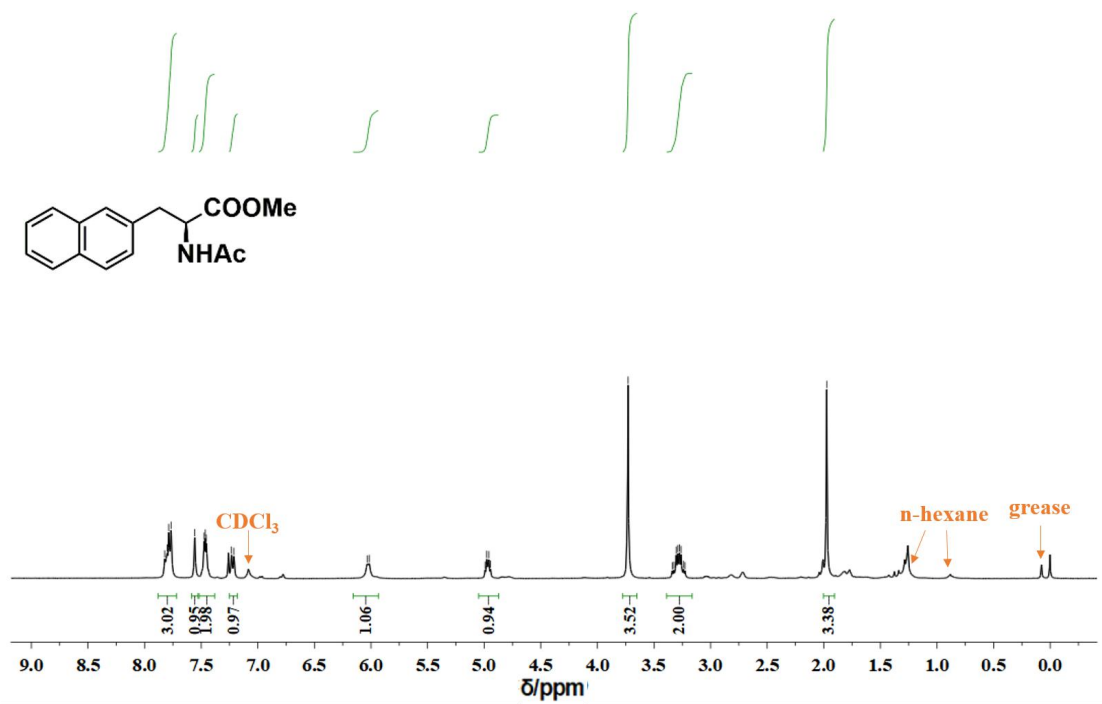<smiles>CCOC(=O)C(Cc1ccccc1)NC(C)=O</smiles>

Enantiomeric excess was detemined by HPLC with a chiralcel OD-H column (hexane $/ i-\mathrm{PrOH}=$ 90/10, $1.0 \mathrm{~mL} / \mathrm{min}) . \mathrm{t}_{\text {minor }}=7.498 \mathrm{~min}, \mathrm{t}_{\text {major }}=9.751 \mathrm{~min}$; ee $=97 \% .{ }^{1} \mathrm{H} \mathrm{NMR}\left(400 \mathrm{MHz}, \mathrm{CDCl}_{3}\right)$ $\delta$ 7.26-7.19 (m, 3H), 7.09 (d, $J=7.4 \mathrm{~Hz}, 2 \mathrm{H}), 6.35(\mathrm{~d}, J=7.4 \mathrm{~Hz}, 1 \mathrm{H}), 4.81(\mathrm{~d}, J=6.8 \mathrm{~Hz}, 2 \mathrm{H})$, 4.11 (q, $J=7.1 \mathrm{~Hz}, 2 \mathrm{H}), 3.06$ (qd, $J=13.8,6.1 \mathrm{~Hz}, 2 \mathrm{H}), 1.92$ (s, 3H), 1.19 (t, $J=7.1 \mathrm{~Hz}, 3 \mathrm{H})$. 
Chromatogram

$\mathrm{mV}$

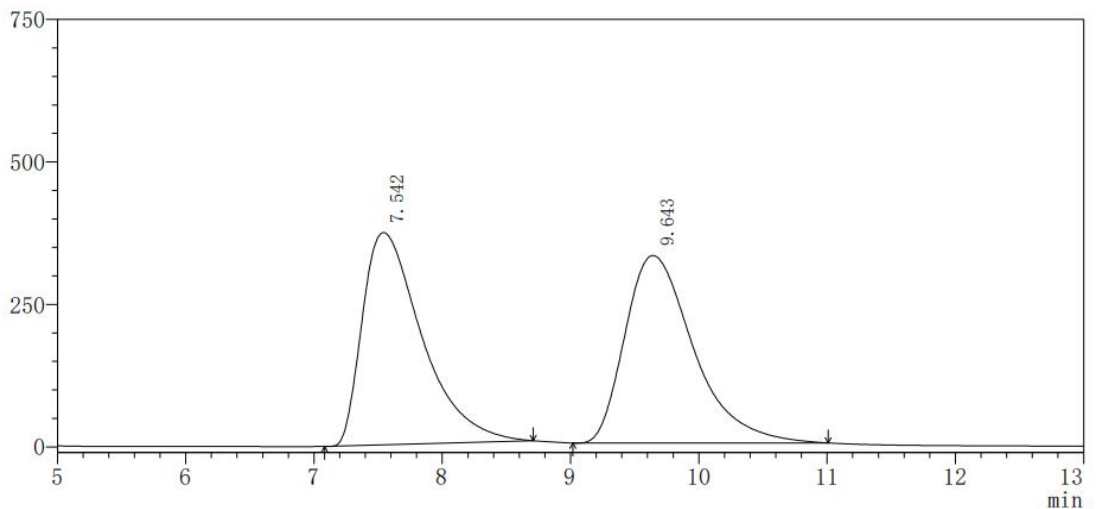

$220 \mathrm{~nm}$

\begin{tabular}{|r|r|r|r|r|r|r|}
\hline \multicolumn{1}{|c|}{ ID\# } & Start & \multicolumn{1}{c|}{ End } & Ret. Time & Height & Area & \multicolumn{1}{c|}{ Area\% } \\
\hline 1 & 7.083 & 8.708 & 7.542 & 372561 & 12060233 & 49.603 \\
\hline 2 & 9.017 & 11.008 & 9.643 & 329140 & 12253201 & 50.397 \\
\hline & & & & 701701 & 24313434 & 100.000 \\
\hline
\end{tabular}

Chromatogram

$\mathrm{mV}$

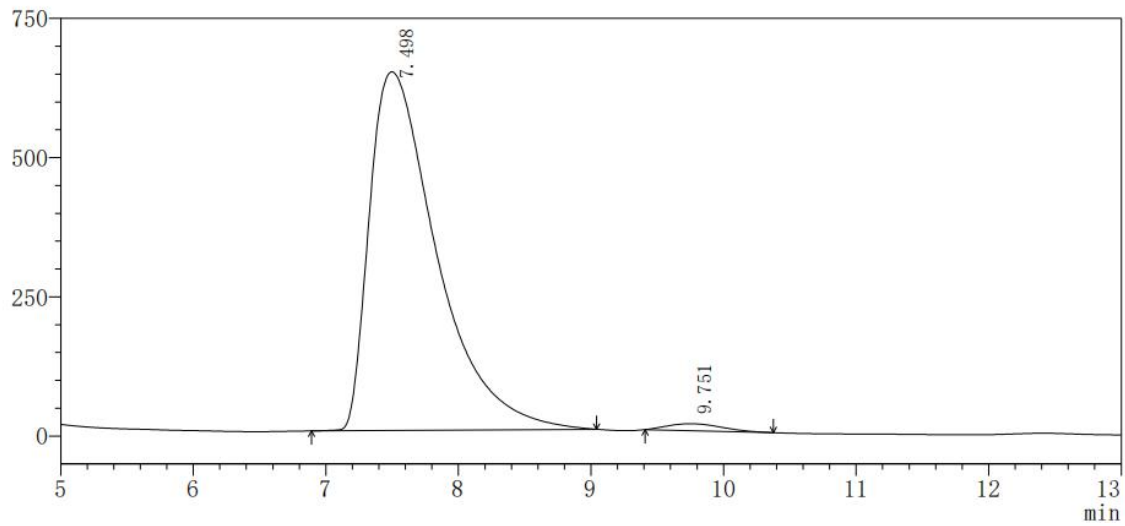

$220 \mathrm{~nm}$

\begin{tabular}{|c|c|c|c|c|c|c|}
\hline ID\# & Start & End & Ret. Time & Height & Area & Area\% \\
\hline 1 & 6.892 & 9.042 & 7.498 & 644173 & 22767311 & 98.457 \\
\hline 2 & 9. 408 & 10.375 & 9.751 & 12500 & 356758 & 1.543 \\
\hline & & & & 656673 & 23124068 & 100.000 \\
\hline
\end{tabular}



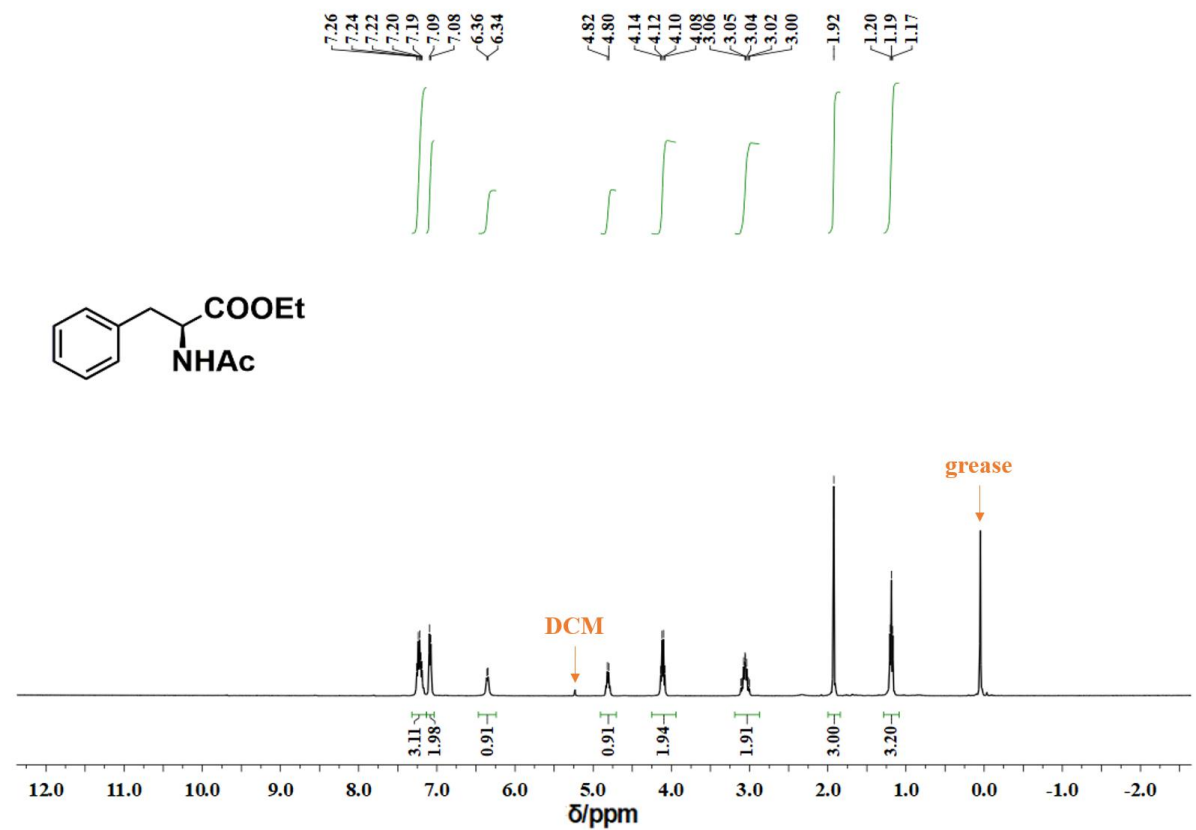<smiles>CC[C@H](N)C(=O)OC</smiles>

Enantiomeric excess was detemined by HPLC with a chiralcel IA column (hexane $/ i$ - $\mathrm{PrOH}=90 / 10$, $0.6 \mathrm{~mL} / \mathrm{min}) . \mathrm{t}_{\text {minor }}=13.242 \mathrm{~min}, \mathrm{t}_{\text {major }}=16.992 \mathrm{~min}$; ee $=40 \% .{ }^{1} \mathrm{H} \mathrm{NMR}\left(400 \mathrm{MHz}, \mathrm{CDCl}_{3}\right) \delta$ $6.14(\mathrm{~s}, 1 \mathrm{H}), 4.57(\mathrm{dd}, J=14.5,7.3 \mathrm{~Hz}, 1 \mathrm{H}), 3.75(\mathrm{~d}, J=6.4 \mathrm{~Hz}, 3 \mathrm{H}), 2.01(\mathrm{~d}, J=6.4 \mathrm{~Hz}, 3 \mathrm{H})$, $1.84(\mathrm{~s}, 1 \mathrm{H}), 1.39(\mathrm{~d}, J=7.2 \mathrm{~Hz}, 3 \mathrm{H})$.

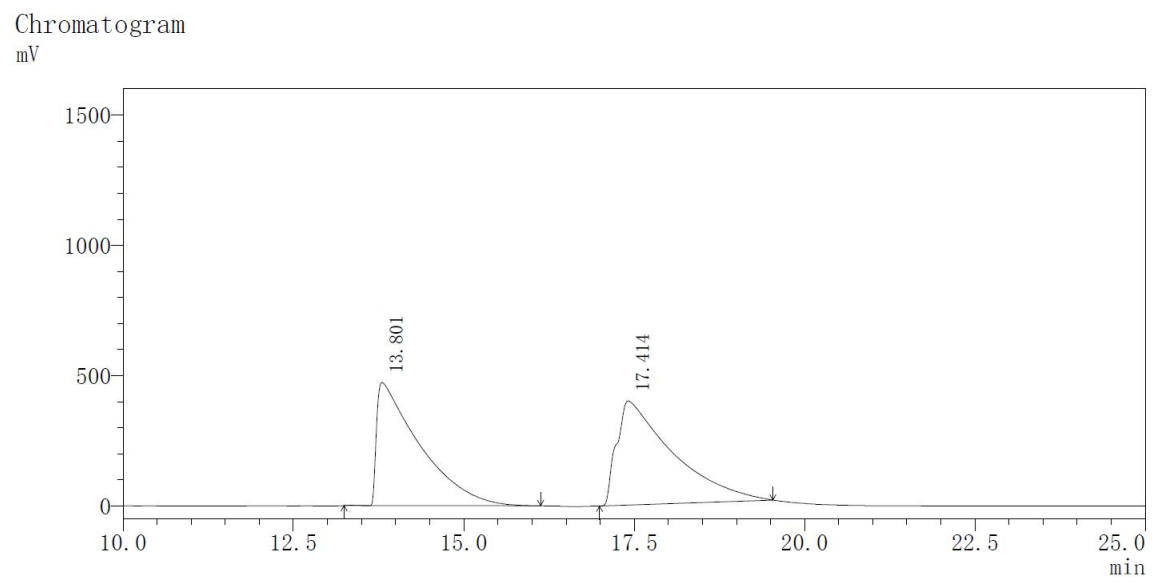

\begin{tabular}{|r|c|c|r|r|r|r|}
\hline ID\# & Start & End & Ret. Time & Height & Area & \multicolumn{1}{|c|}{ Area\% } \\
\hline 1 & 13.242 & 16.125 & 13.801 & 472640 & 20693200 & 47.718 \\
\hline 2 & 16.992 & 19.533 & 17.414 & 399335 & 22672772 & 52.282 \\
\hline & & & & 871976 & 43365972 & 100.000 \\
\hline
\end{tabular}


Chromatogram

$\mathrm{mV}$

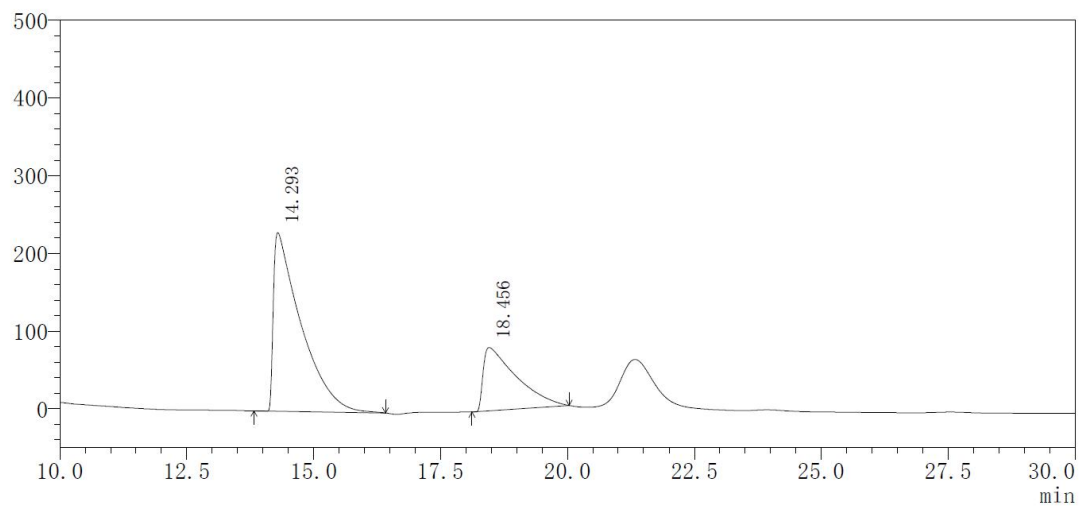

\begin{tabular}{|c|c|c|c|c|c|c|}
\hline & $v 1$ & & & & & \\
\hline ID\# & Start & End & Ret. Time & Height & Area & Area\% \\
\hline 1 & 13.825 & 16.417 & 14.293 & 230284 & 8663071 & 70.163 \\
\hline 2 & 18.117 & 20.033 & 18.456 & 81516 & 3683997 & 29.837 \\
\hline & & & & 311800 & 12347069 & 100.000 \\
\hline
\end{tabular}
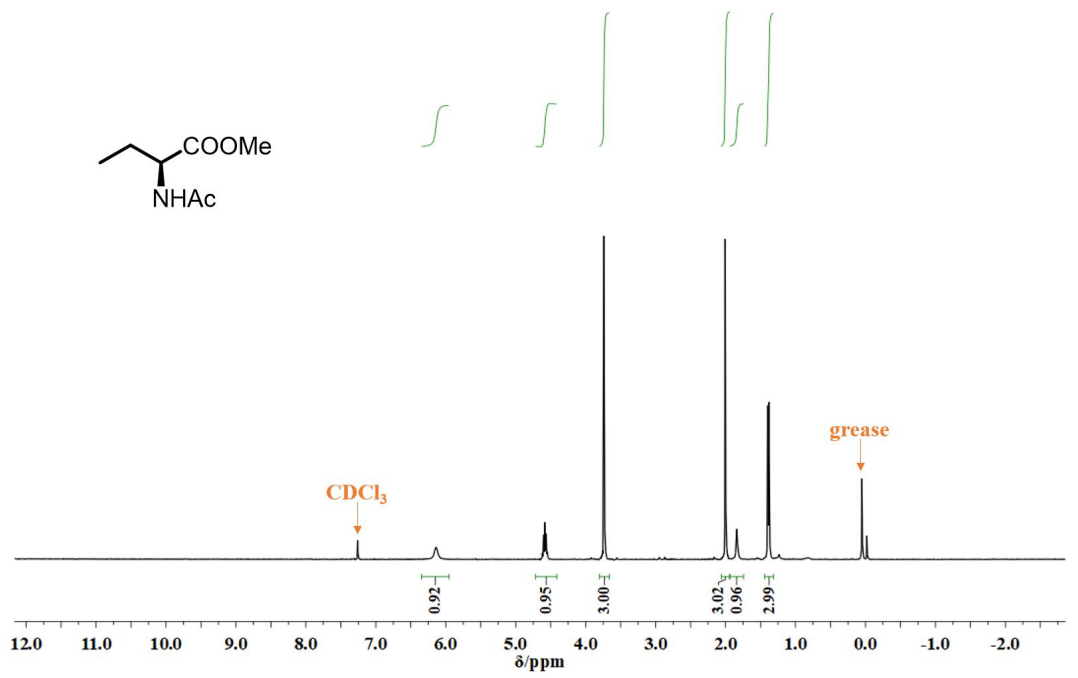


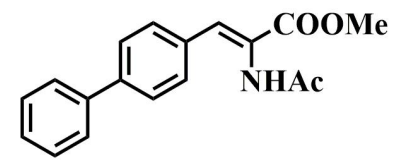

${ }^{1} \mathrm{H}$ NMR $\left(500 \mathrm{MHz}, \mathrm{CDCl}_{3}\right) \delta 7.58(\mathrm{~m}, 6 \mathrm{H}), 7.42(\mathrm{~m}, 5 \mathrm{H}), 3.84(\mathrm{~s}, 3 \mathrm{H}), 2.14(\mathrm{~s}, 3 \mathrm{H})$.

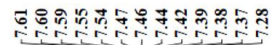
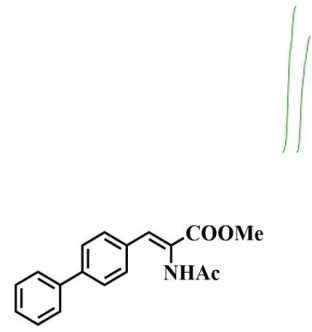

$\stackrel{\overrightarrow{0}}{\vec{i}} \overrightarrow{\vec{a}}$
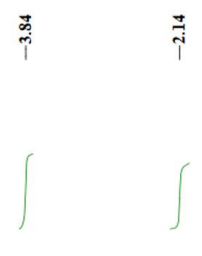

(1)

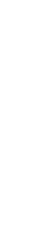




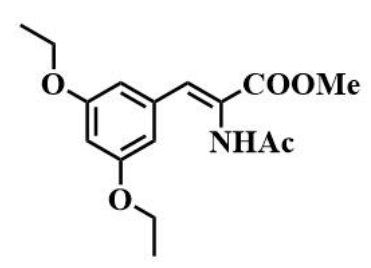

${ }^{1} \mathrm{H}$ NMR $\left(500 \mathrm{MHz}, \mathrm{CDCl}_{3}\right) \delta 7.49$ (br, 1H), $7.18(\mathrm{~s}, 1 \mathrm{H}), 6.58(\mathrm{~s}, 2 \mathrm{H}), 6.38(\mathrm{~s}, 1 \mathrm{H}), 4.25(\mathrm{~d}, J=$ $5.0 \mathrm{~Hz}, 2 \mathrm{H}), 3.95(\mathrm{~m}, 4.5 \mathrm{H}), 3.78(\mathrm{~s}, 0.5 \mathrm{H}), 2.06(\mathrm{~s}, 3 \mathrm{H}), 1.36(\mathrm{~m}, 10 \mathrm{H}) .{ }^{13} \mathrm{C}$ NMR $(126 \mathrm{MHz}$, $\left.\mathrm{CDCl}_{3}\right) \delta 169.20,165.85,142.08,140.12,132.65,132.25,130.32,128.90,127.80,127.15,127.03$, 124.16, 58.34, 52.68, 23.34, 18.40. Elemental analysis: Calcd for $\mathrm{C}_{16} \mathrm{H}_{21} \mathrm{NO}_{5}$. C: 62.53, H: 6.89; Found: C, 62.55, H, 6.87. MS: m/z $330.1338\left(\right.$ Calcd m/z 330.1317 for $\left.[\mathrm{M}+\mathrm{Na}]^{+}\right)$.

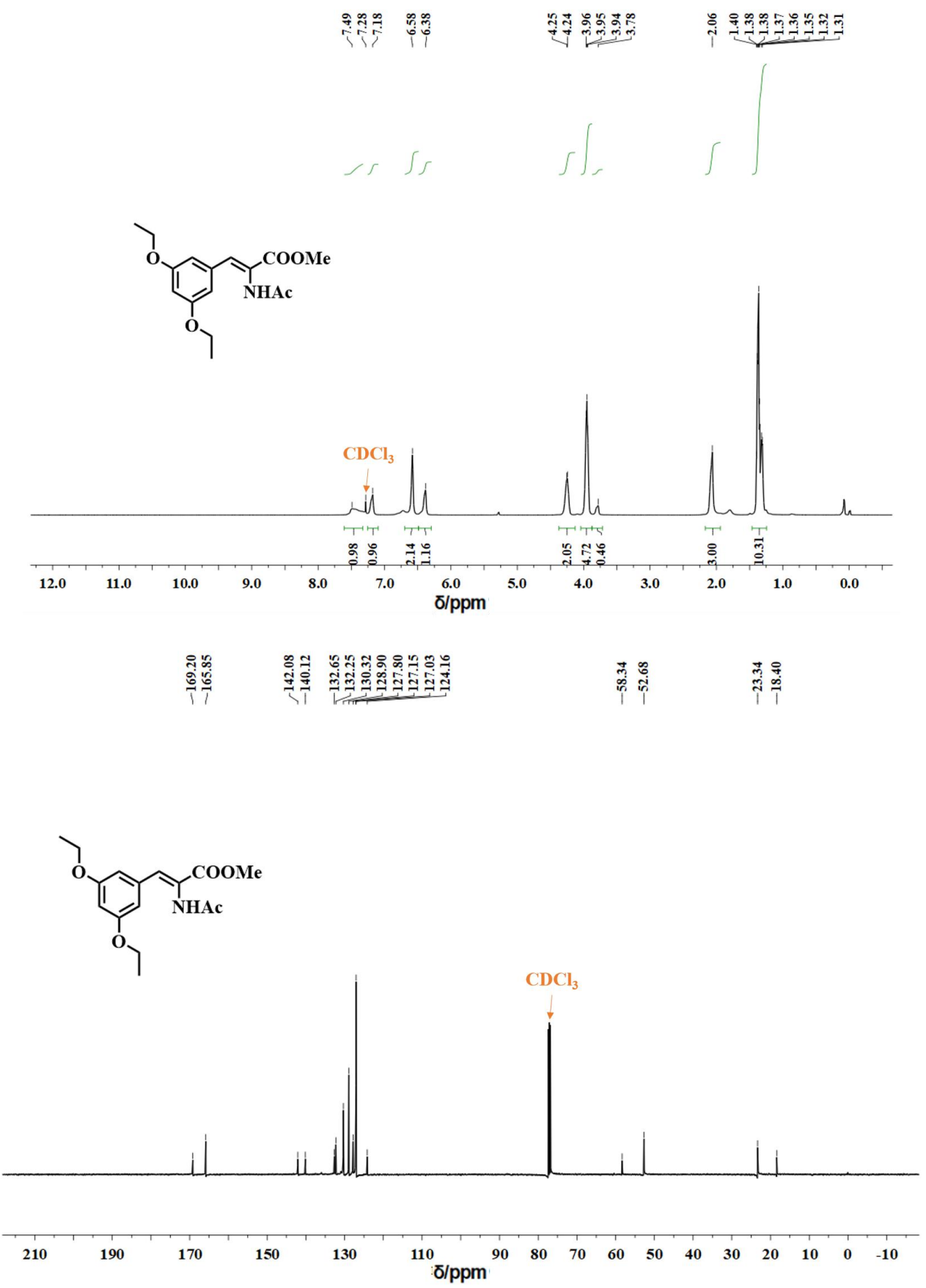




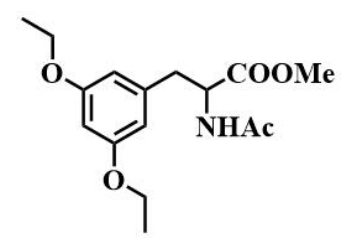

${ }^{1} \mathrm{H}$ NMR $\left(500 \mathrm{MHz}, \mathrm{CDCl}_{3}\right) \delta 6.35(\mathrm{~s}, 1 \mathrm{H}), 6.25(\mathrm{~s}, 2 \mathrm{H}), 5.98(\mathrm{~d}, J=7.2 \mathrm{~Hz}, 1 \mathrm{H}), 4.85(\mathrm{dd}, J=$ 13.4, $5.9 \mathrm{~Hz}, 1 \mathrm{H}), 4.20(\mathrm{dtd}, J=10.3,6.9,3.4 \mathrm{~Hz}, 2 \mathrm{H}), 3.99(\mathrm{~m}, 4 \mathrm{H}), 3.76(\mathrm{~s}, 0.5 \mathrm{H}), 3.05(\mathrm{~d}, J=$ $5.8 \mathrm{~Hz}, 2 \mathrm{H}), 2.01(\mathrm{~s}, 3 \mathrm{H}), 1.40(\mathrm{t}, J=7.0 \mathrm{~Hz}, 6 \mathrm{H}), 1.28(\mathrm{t}, J=7.1 \mathrm{~Hz}, 4 \mathrm{H}) .{ }^{13} \mathrm{C}$ NMR $(126 \mathrm{MHz}$, $\left.\mathrm{CDCl}_{3}\right) \delta 171.65,169.62,160.14,137.92,107.80,99.97,63.41,61.52,52.99,38.08,23.21,14.81$, 14.14. Elemental analysis: Calcd for $\mathrm{C}_{16} \mathrm{H}_{23} \mathrm{NO}_{5}$. C: 62.12, H: 7.49; Found: $\mathrm{C}, 62.10, \mathrm{H}, 7.45$. MS: $\mathrm{m} / \mathrm{z} 310.1664\left(\right.$ Calcd m/z 330.1654 for $\left.[\mathrm{M}+\mathrm{H}]^{+}\right)$.
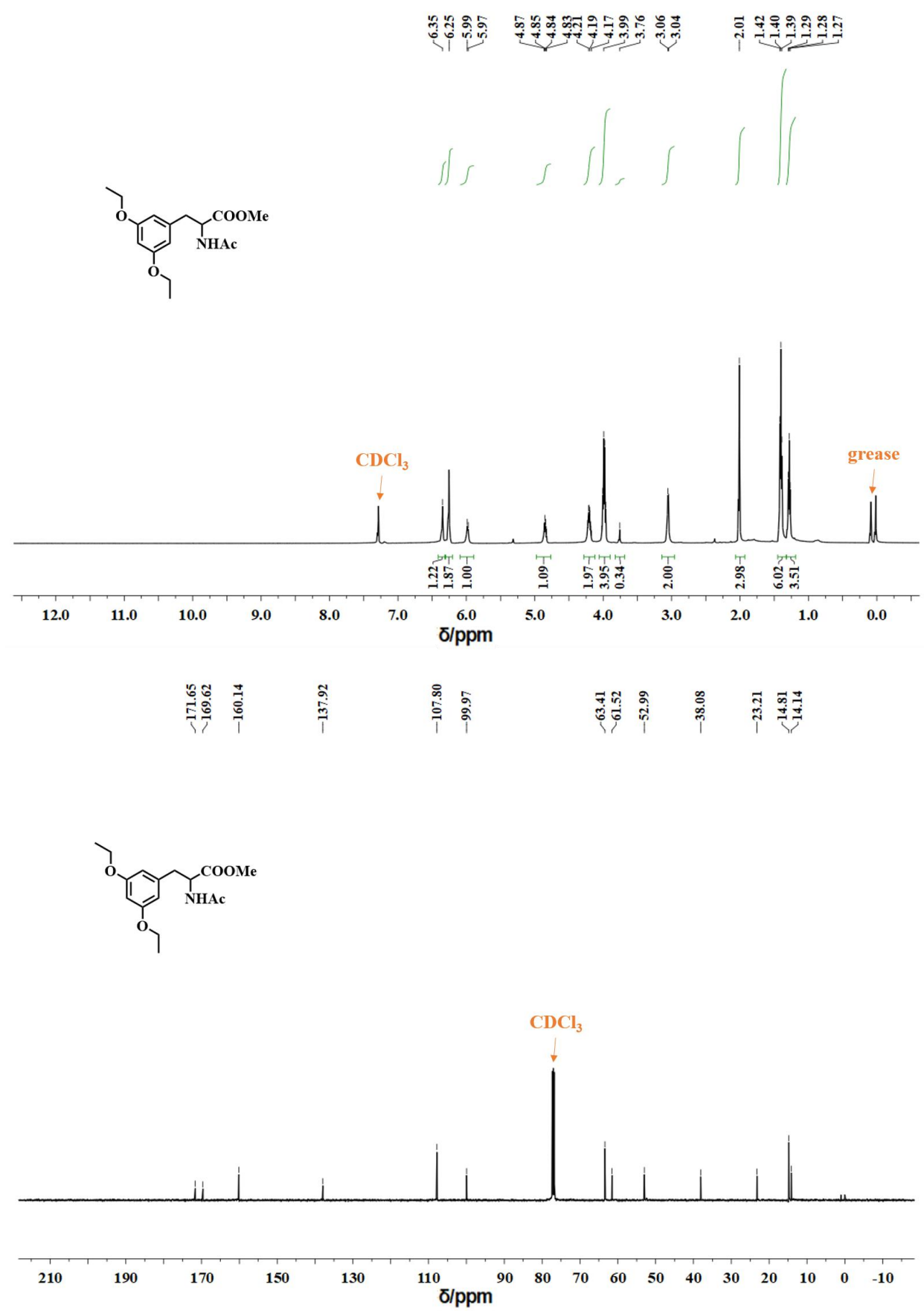


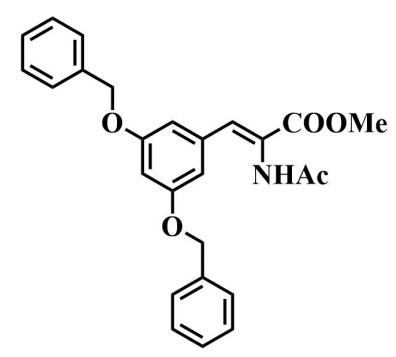

${ }^{1} \mathrm{H}$ NMR (500 MHz, CDCl $) \delta 7.39$ (d, $\left.J=27.4 \mathrm{~Hz}, 10 \mathrm{H}\right), 7.19(\mathrm{~s}, 1 \mathrm{H}), 6.68(\mathrm{~d}, J=53.0 \mathrm{~Hz}, 3 \mathrm{H})$, $5.03(\mathrm{~s}, 4 \mathrm{H}), 3.84(\mathrm{~s}, 3 \mathrm{H}), 2.06(\mathrm{~s}, 3 \mathrm{H}) .{ }^{13} \mathrm{C} \mathrm{NMR}\left(126 \mathrm{MHz}, \mathrm{CDCl}_{3}\right) \delta 169.01,165.67,159.93$, 136.61, 135.45, 131.85, 128.68, 128.14, 127.51, 125.14, 108.71, 103.48, 70.16, 52.73, 23.26. Elemental analysis: Calcd for $\mathrm{C}_{26} \mathrm{H}_{25} \mathrm{NO}_{5}$. C: 72.37, H: 5.84; Found: C, 72.39, H, 5.79. MS: m/z $454.1662\left(\right.$ Calcd $\mathrm{m} / \mathrm{z} 454.1630$ for $\left.[\mathrm{M}+\mathrm{Na}]^{+}\right)$.
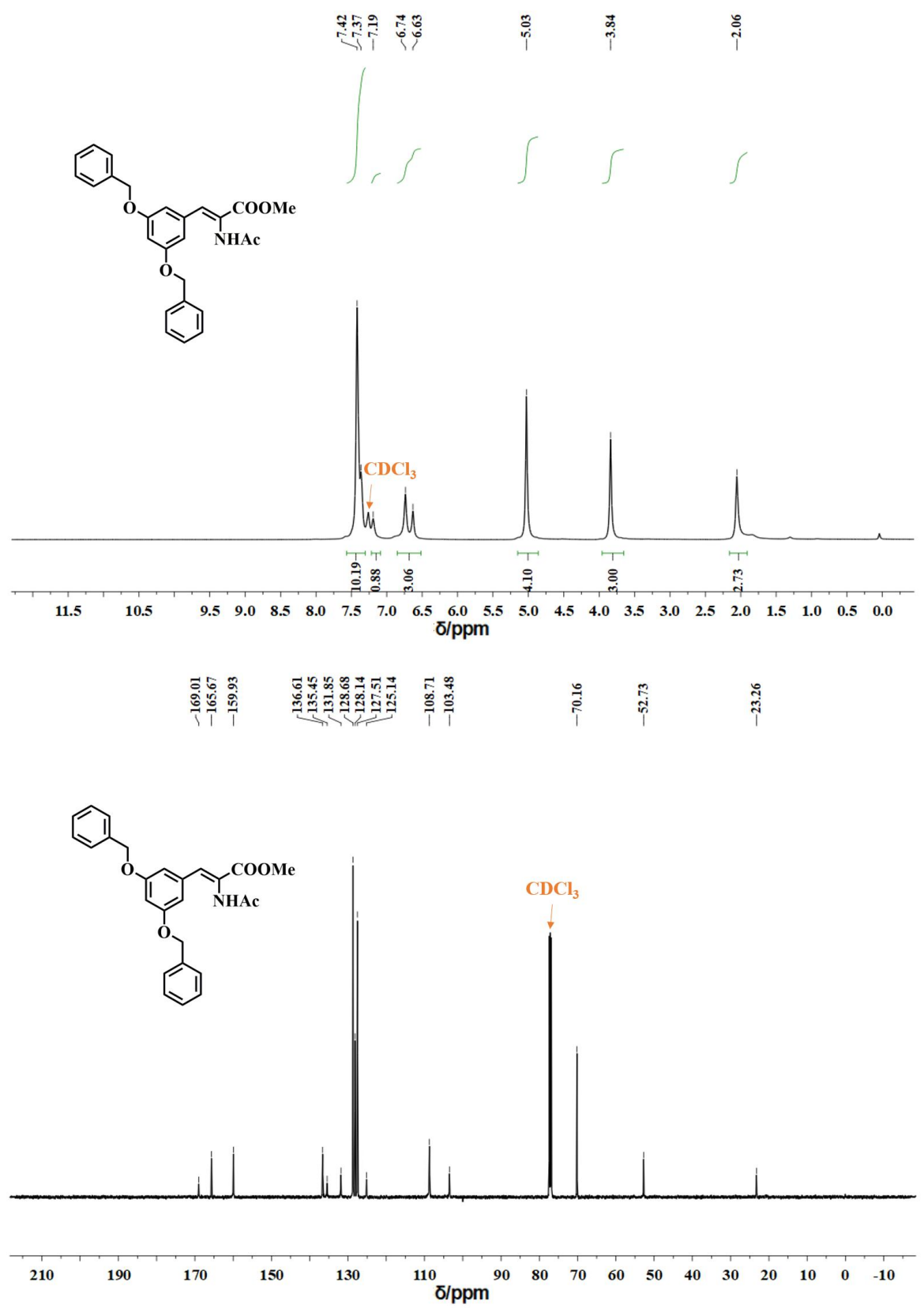


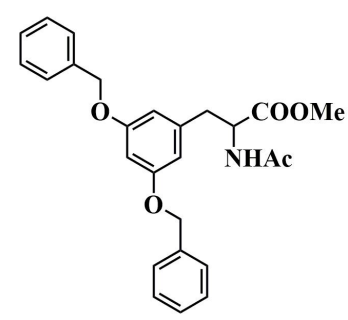

${ }^{1} \mathrm{H}$ NMR $\left(400 \mathrm{MHz}, \mathrm{CDCl}_{3}\right) \delta 7.37(\mathrm{~m}, 10 \mathrm{H}), 6.53(\mathrm{~s}, 1 \mathrm{H}), 6.35(\mathrm{~s}, 2 \mathrm{H}), 5.98(\mathrm{~d}, J=7.3 \mathrm{~Hz}, 1 \mathrm{H})$, $5.01(\mathrm{~s}, 4 \mathrm{H}), 4.86(\mathrm{~d}, J=6.8 \mathrm{~Hz}, 1 \mathrm{H}), 3.69(\mathrm{~s}, 3 \mathrm{H}), 3.05(\mathrm{t}, J=5.5 \mathrm{~Hz}, 2 \mathrm{H}), 1.95(\mathrm{~s}, 3 \mathrm{H}) .{ }^{13} \mathrm{C}$ NMR $\left(101 \mathrm{MHz}, \mathrm{CDCl}_{3}\right) \delta 172.25,169.91,160.27,138.36,136.98,128.85,128.27,127.68$, 108.65, 101.04, 70.24, 53.19, 52.59, 38.23, 23.38. Elemental analysis: Calcd for $\mathrm{C}_{26} \mathrm{H}_{27} \mathrm{NO}_{5}$. C: 72.04, H: 6.28; Found: C, 72.06, H, 6.25. MS: m/z 456.1823 (Calcd m/z 456.1787 for $[\mathrm{M}+\mathrm{Na}]^{+}$).
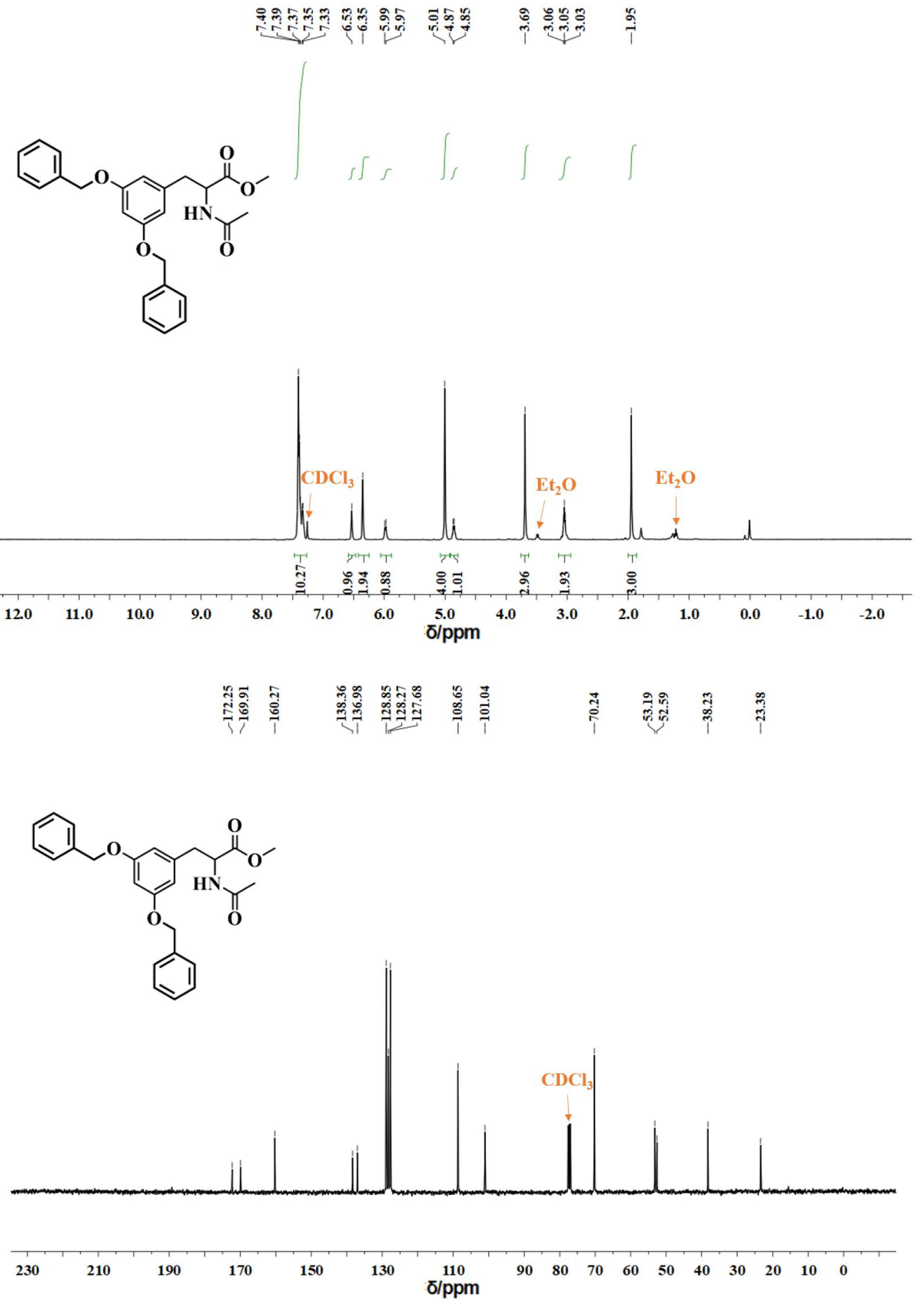
Chromatogram

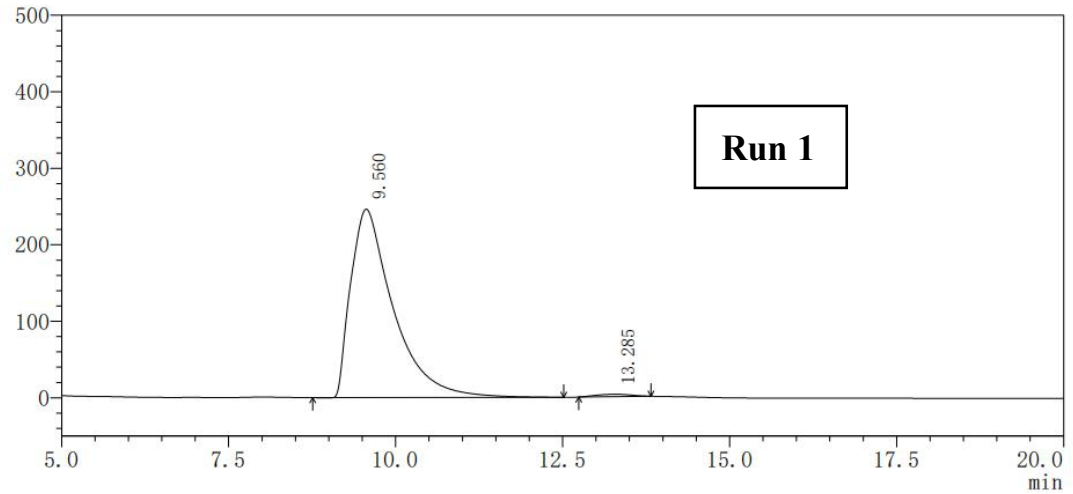

\begin{tabular}{|r|r|r|r|r|r|r|}
\hline ID\# & \multicolumn{1}{|c|}{ Start } & \multicolumn{1}{c|}{ End } & \multicolumn{1}{|c|}{ Ret. Time } & \multicolumn{1}{c|}{ Height } & \multicolumn{1}{c|}{ Area } & 98.956 \\
\hline 1 & 8.758 & 12.517 & 9.560 & 246414 & 10949552 & 1.044 \\
\hline 2 & 12.742 & 13.825 & 13.285 & 3118 & 115476 & 100.000 \\
\hline & & & & 249532 & 11065028 & \\
\hline
\end{tabular}

Chromatogram

$\mathrm{mV}$

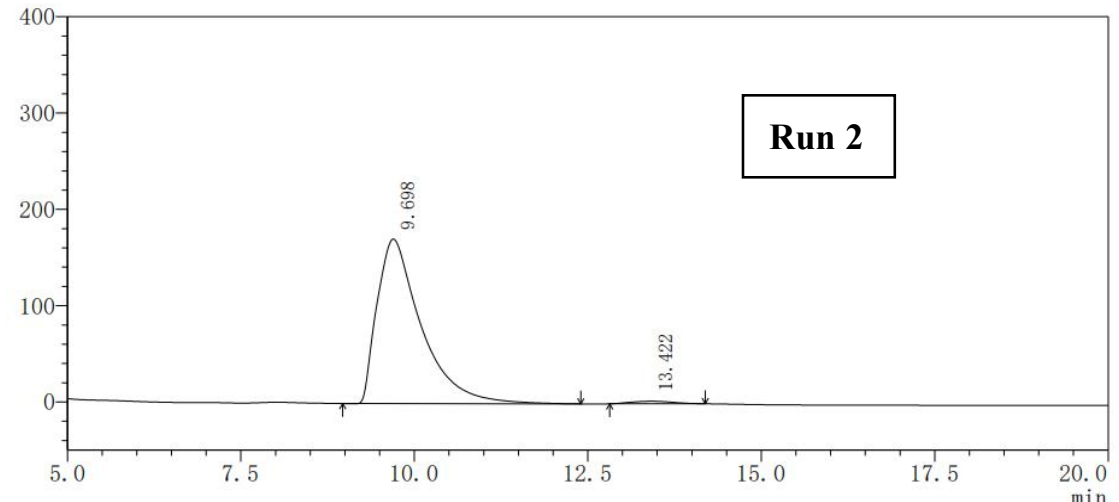

\begin{tabular}{|r|r|r|r|r|r|r|}
\hline ID\# & \multicolumn{1}{|c|}{ Start } & \multicolumn{1}{|c|}{ End } & \multicolumn{1}{c|}{ Ret. Time } & \multicolumn{1}{c|}{ Height } & \multicolumn{1}{c|}{ Area } & Area\% \\
\hline 1 & 8.967 & 12.400 & 9.698 & 170856 & 7568032 & 98.546 \\
\hline 2 & 12.817 & 14.192 & 13.422 & 2639 & 111659 & 1.454 \\
\hline & & & & 173494 & 7679690 & 100.000 \\
\hline
\end{tabular}

Chromatogram

$\mathrm{mV}$

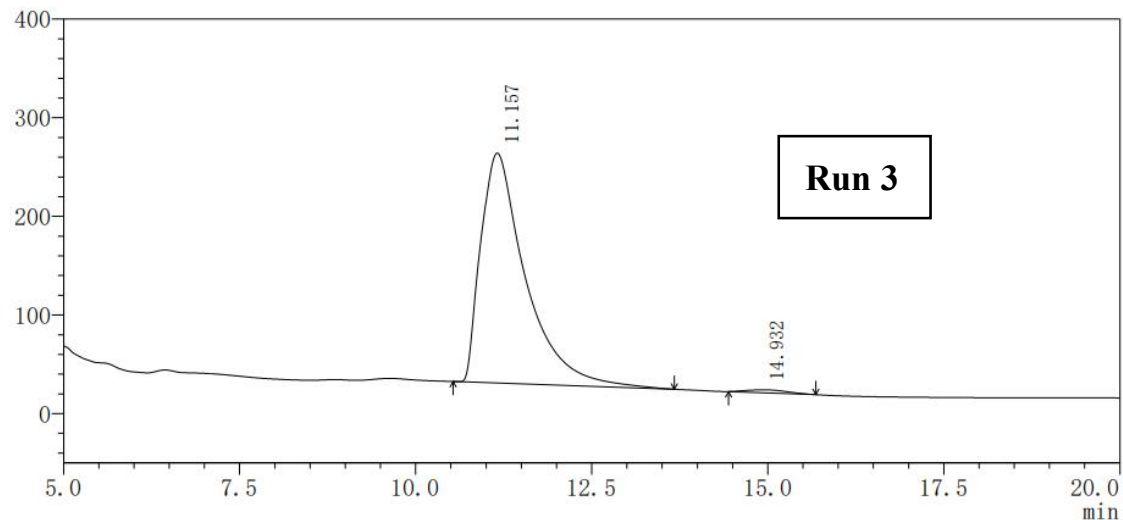

$220 \mathrm{~nm}$

\begin{tabular}{|r|c|r|r|r|r|r|}
\hline \multicolumn{1}{|c|}{$220 \mathrm{~nm}$} & \multicolumn{1}{c|}{ Area } & \multicolumn{1}{c|}{ Area\% } \\
\hline 1 & Start & \multicolumn{1}{c|}{ End } & Ret. Time & \multicolumn{1}{c|}{ Height } & \multicolumn{1}{c|}{ Area 820} \\
\hline 2 & 10.533 & 13.675 & 11.157 & 233257 & 10268020 & 1.180 \\
\hline & 14.442 & 15.683 & 14.932 & 2991 & 122558 & 100.000 \\
\hline
\end{tabular}


Chromatogram

$\mathrm{mV}$

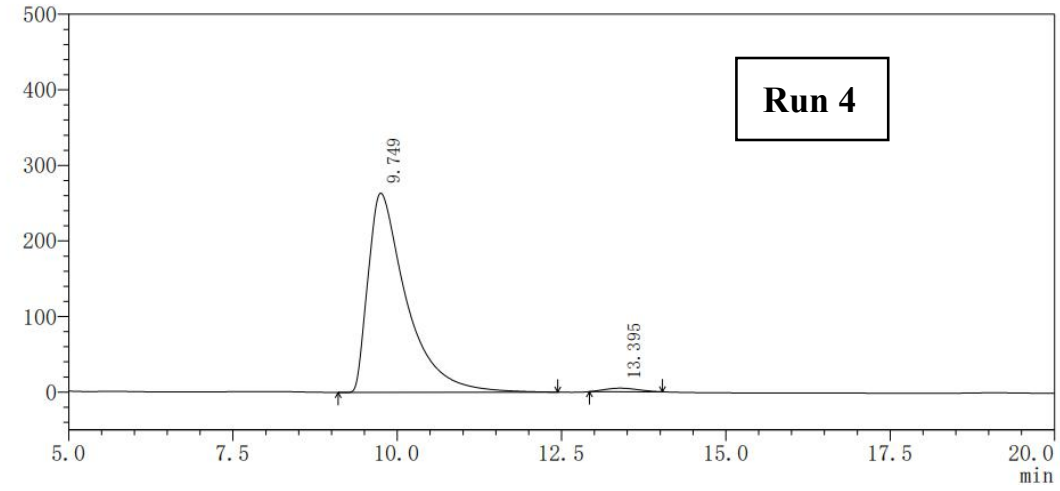

$220 \mathrm{~nm}$

\begin{tabular}{|r|r|r|r|r|r|r|}
\hline ID\# & Start & \multicolumn{1}{|c|}{ End } & \multicolumn{1}{|c|}{ Ret. Time } & \multicolumn{1}{c|}{ Height } & \multicolumn{1}{c|}{ Area } & Area\% \\
\hline 1 & 9.100 & 12.442 & 9.749 & 263726 & 10707051 & 98.485 \\
\hline 2 & 12.925 & 14.033 & 13.395 & 4692 & 164746 & 1.515 \\
\hline & & & & 268418 & 10871797 & 100.000 \\
\hline
\end{tabular}

Chromatogram

$\mathrm{mV}$

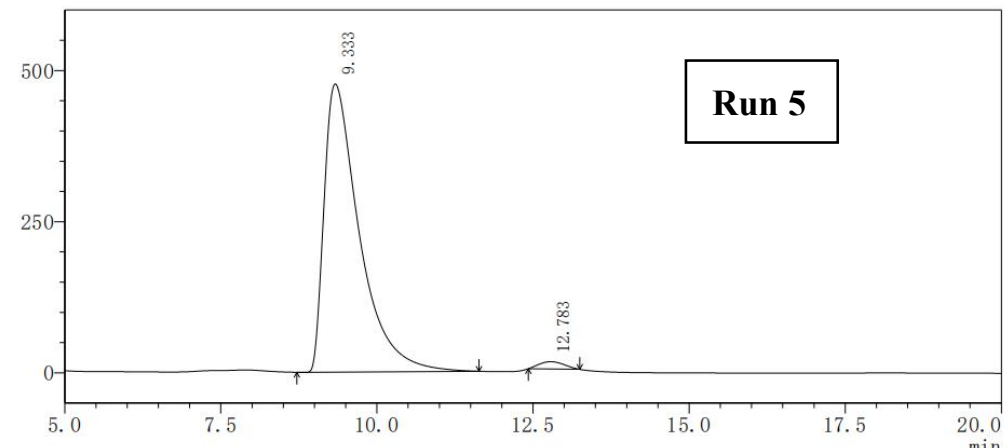

$220 \mathrm{~nm}$

\begin{tabular}{|r|r|r|r|r|r|r|}
\hline \multicolumn{1}{|c|}{ ID\# } & \multicolumn{1}{|c|}{ Start } & \multicolumn{1}{c|}{ End } & \multicolumn{1}{c|}{ Ret. Time } & \multicolumn{1}{c|}{ Height } & \multicolumn{1}{c|}{ Area } & Area\% \\
\hline 1 & 8.717 & 11.633 & 9.333 & 476610 & 18732634 & 98.211 \\
\hline 2 & 12.425 & 13.250 & 12.783 & 12122 & 341175 & 1.789 \\
\hline & & & & 488732 & 19073809 & 100.000 \\
\hline
\end{tabular}

Chromatogram

$\mathrm{mV}$

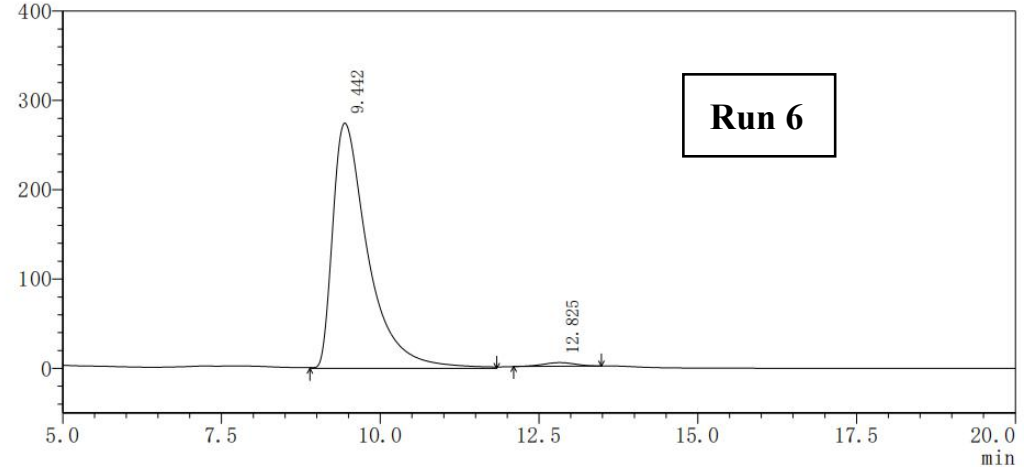

$220 \mathrm{~nm}$

\begin{tabular}{|r|r|r|r|r|r|r|}
\hline ID\# & \multicolumn{1}{|c|}{ Start } & \multicolumn{1}{c|}{ End } & \multicolumn{1}{c|}{ Ret. Time } & \multicolumn{1}{c|}{ Height } & \multicolumn{1}{c|}{ Area } & Area\% \\
\hline 1 & 8.892 & 11.833 & 9.442 & 274595 & 10627164 & 98.667 \\
\hline 2 & 12.100 & 13.483 & 12.825 & 4046 & 143612 & 1.333 \\
\hline & & & & 278641 & 10770776 & 100.000 \\
\hline
\end{tabular}




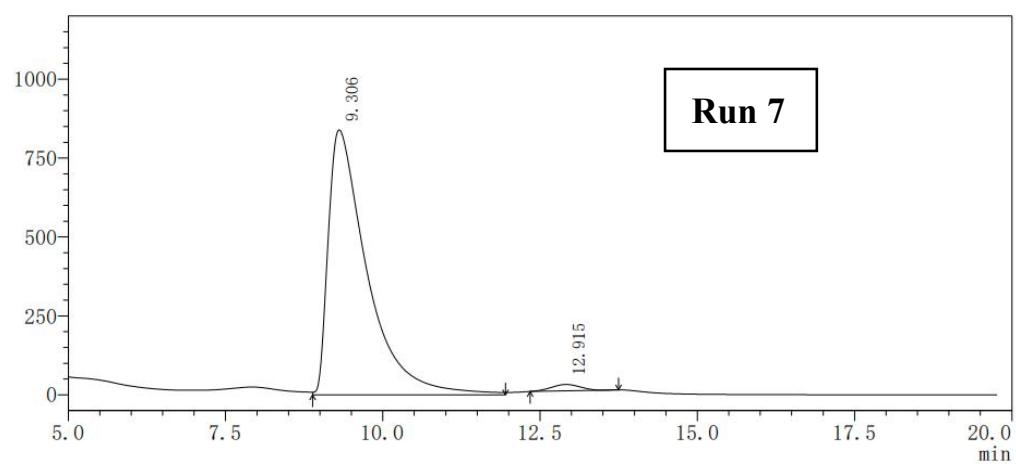

$220 \mathrm{~nm}$

\begin{tabular}{|r|r|r|r|r|r|r|}
\hline \multicolumn{1}{|c|}{ ID\# } & \multicolumn{1}{|c|}{ Start } & \multicolumn{1}{c|}{ End } & \multicolumn{1}{c|}{ Ret. Time } & \multicolumn{1}{c|}{ Height } & \multicolumn{1}{c|}{ Area } & Area\% \\
\hline 1 & 8.883 & 11.950 & 9.306 & 839627 & 36110692 & 98.286 \\
\hline 2 & 12.342 & 13.750 & 12.915 & 19924 & 629916 & 1.714 \\
\hline & & & & 859551 & 36740608 & 100.000 \\
\hline
\end{tabular}

Chromatogram

$\mathrm{mV}$

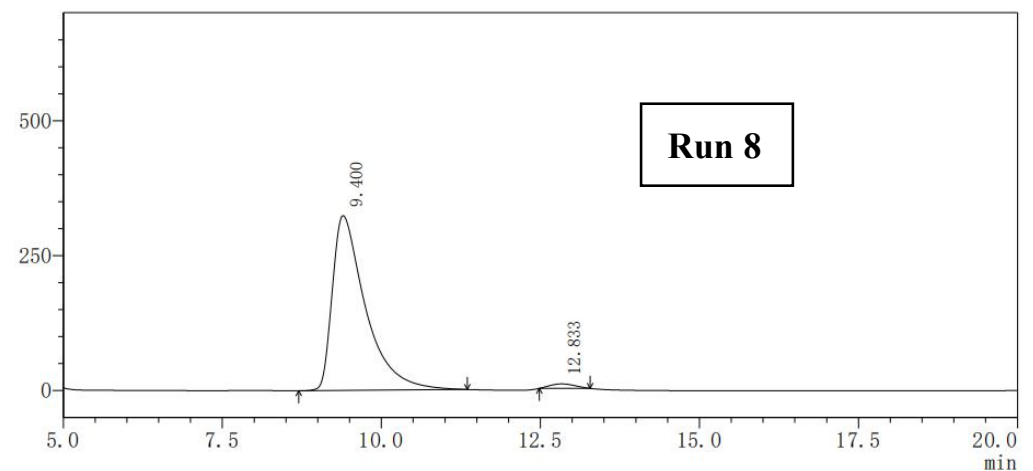

\begin{tabular}{|r|r|r|r|r|r|r|}
\hline \multicolumn{1}{|c|}{$220 \mathrm{~nm}$} \\
\multicolumn{1}{|c|}{ Start } & End & Ret. Time & \multicolumn{1}{c|}{ Height } & \multicolumn{1}{c|}{ Area } & Area\% \\
\hline 1 & 8.700 & 11.350 & 9.400 & 323791 & 11776144 & 98.104 \\
\hline 2 & 12.483 & 13.283 & 12.833 & 8307 & 227592 & 1.896 \\
\hline & & & & 332097 & 12003736 & 100.000 \\
\hline
\end{tabular}

Chromatogram

$\mathrm{mV}$

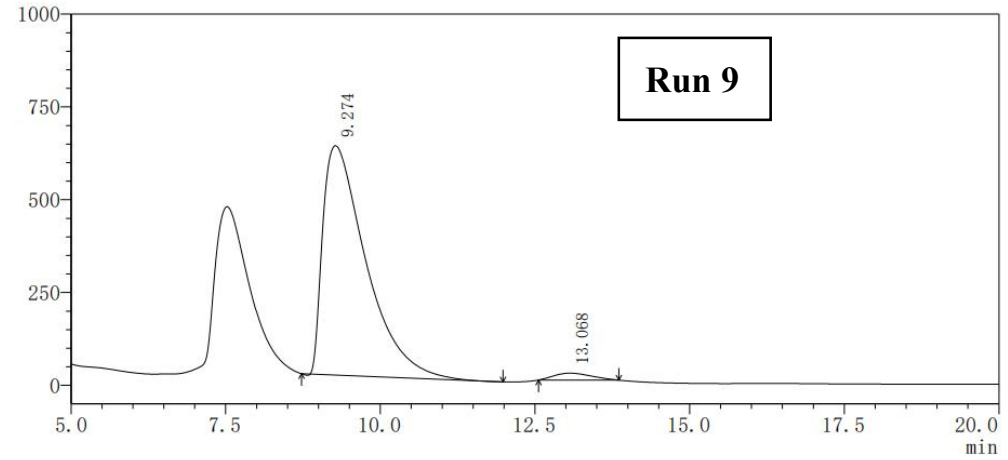

220nm

\begin{tabular}{|r|r|r|r|r|r|r|}
\hline ID\# & \multicolumn{1}{|c|}{ Start } & \multicolumn{1}{c|}{ End } & \multicolumn{1}{c|}{ Ret. Time } & \multicolumn{1}{c|}{ Height } & \multicolumn{1}{c|}{ Area } & \multicolumn{1}{c|}{ Area\% } \\
\hline 1 & 8.725 & 11.983 & 9.274 & 618268 & 30099563 & 97.460 \\
\hline 2 & 12.558 & 13.858 & 13.068 & 18522 & 784380 & 2.540 \\
\hline & & & & 636789 & 30883943 & 100.000 \\
\hline
\end{tabular}




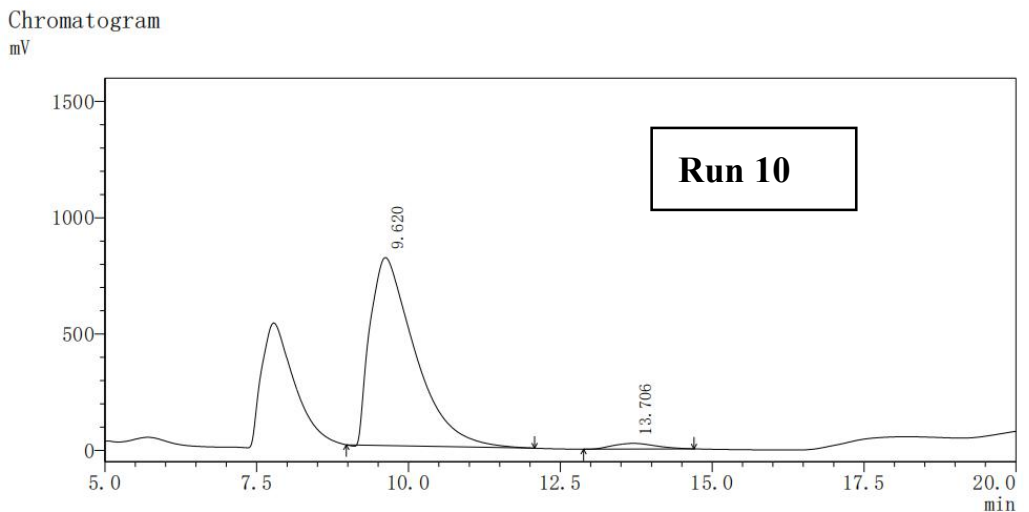

\begin{tabular}{|r|r|r|r|r|r|r|}
\hline \multicolumn{1}{|c|}{$220 \mathrm{~nm}$} \\
\hline Start & \multicolumn{1}{|c|}{ End } & \multicolumn{1}{c|}{ Ret. Time } & \multicolumn{1}{c|}{ Height } & \multicolumn{1}{c|}{ Area } & Area\% \\
\hline 1 & 8.975 & 12.075 & 9.620 & 808202 & 41628231 & 97.184 \\
\hline 2 & 12.883 & 14.700 & 13.706 & 24517 & 1206013 & 2.816 \\
\hline & & & & 832719 & 42834244 & 100.000 \\
\hline
\end{tabular}

\subsection{Asymmetric cyanation reactions}<smiles>COc1ccc(C(C#N)OC(C)=O)cc1</smiles>

Enantiomeric excess was detemined by HPLC with a chiralcel OD column (hexane $/ i-\mathrm{PrOH}=99 / 1$, $1.0 \mathrm{~mL} / \mathrm{min}) . \mathrm{t}_{\text {minor }}=18.213 \mathrm{~min}, \mathrm{t}_{\text {major }}=21.871 \mathrm{~min}$; ee $=85 \% .{ }^{1} \mathrm{H} \mathrm{NMR}\left(400 \mathrm{MHz}, \mathrm{CDCl}_{3}\right) \delta$ $7.44(\mathrm{~d}, J=8.7 \mathrm{~Hz}, 2 \mathrm{H}), 6.94(\mathrm{~d}, J=8.8 \mathrm{~Hz}, 2 \mathrm{H}), 6.34$ (s, 1H), $3.82(\mathrm{~s}, 3 \mathrm{H}), 2.13$ (s, 3H).

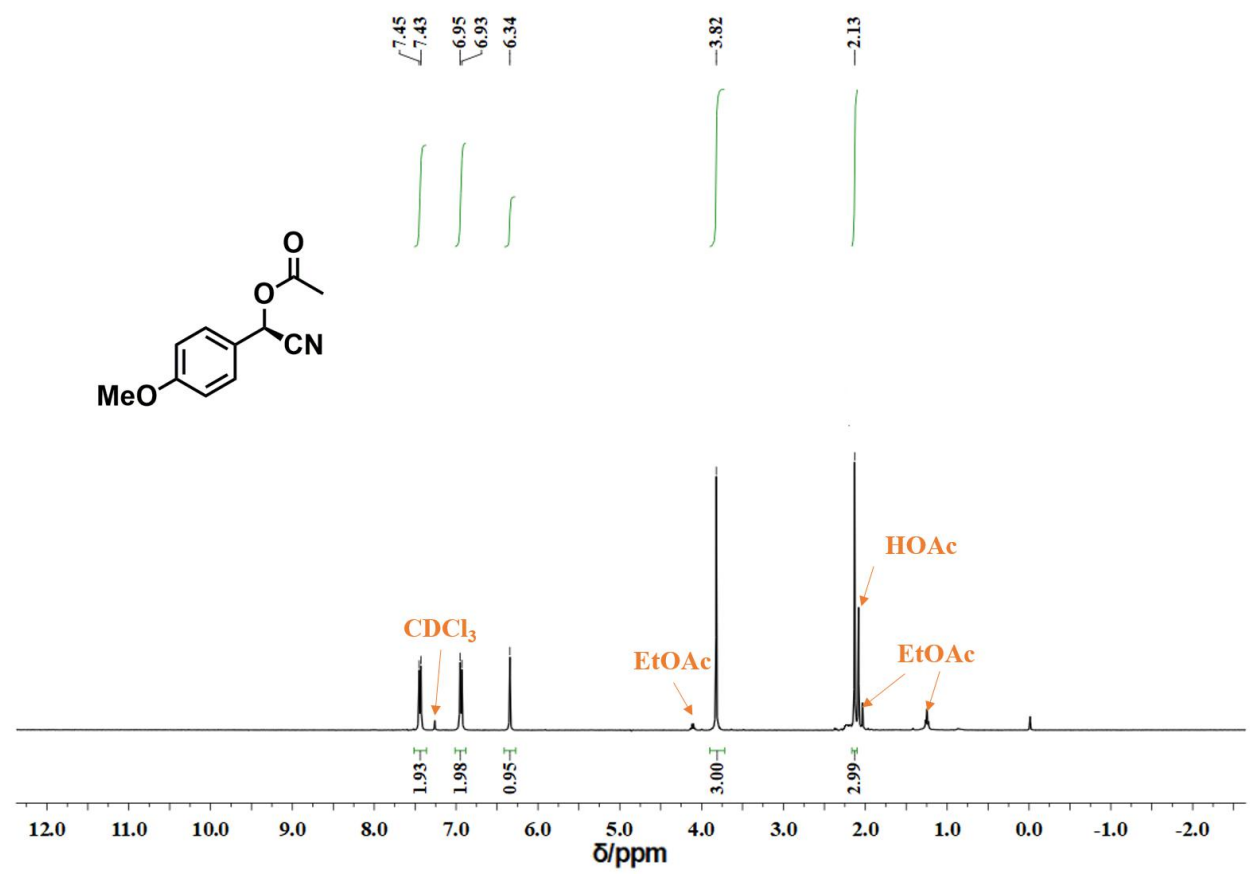




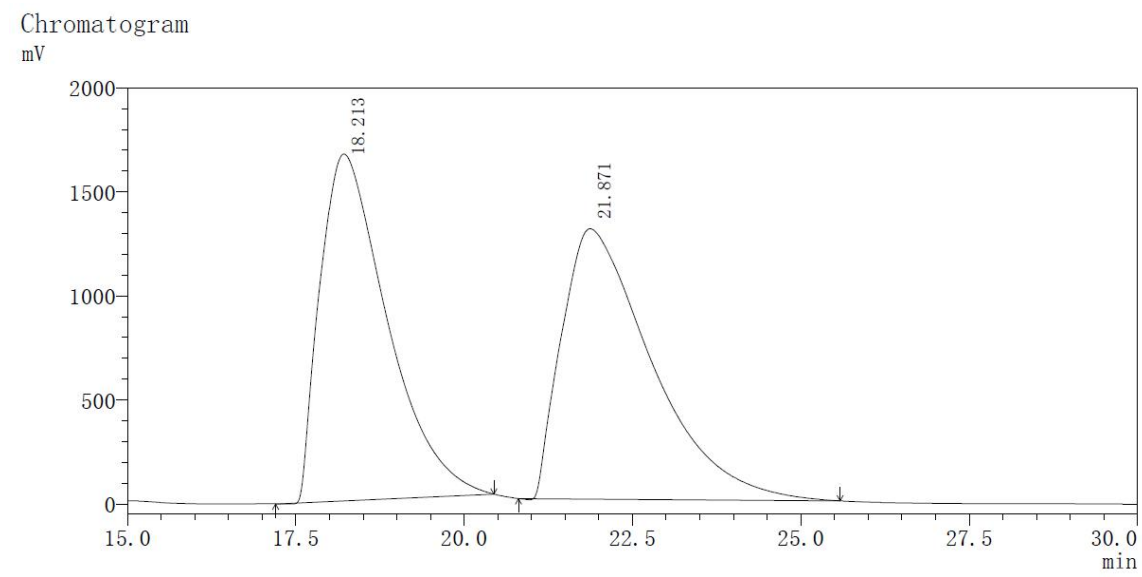

\begin{tabular}{|r|c|c|c|c|c|r|}
\hline ID\# & Start & End & Ret. Time & Height & Area & Area\% \\
\hline 1 & 17.200 & 20.442 & 18.213 & 1667535 & 115405967 & 48.840 \\
\hline 2 & 20.808 & 25.583 & 21.871 & 1300063 & 120890322 & 51.160 \\
\hline & & & & 2967598 & 236296289 & 100.000 \\
\hline
\end{tabular}

Chromatogram

$\mathrm{mV}$

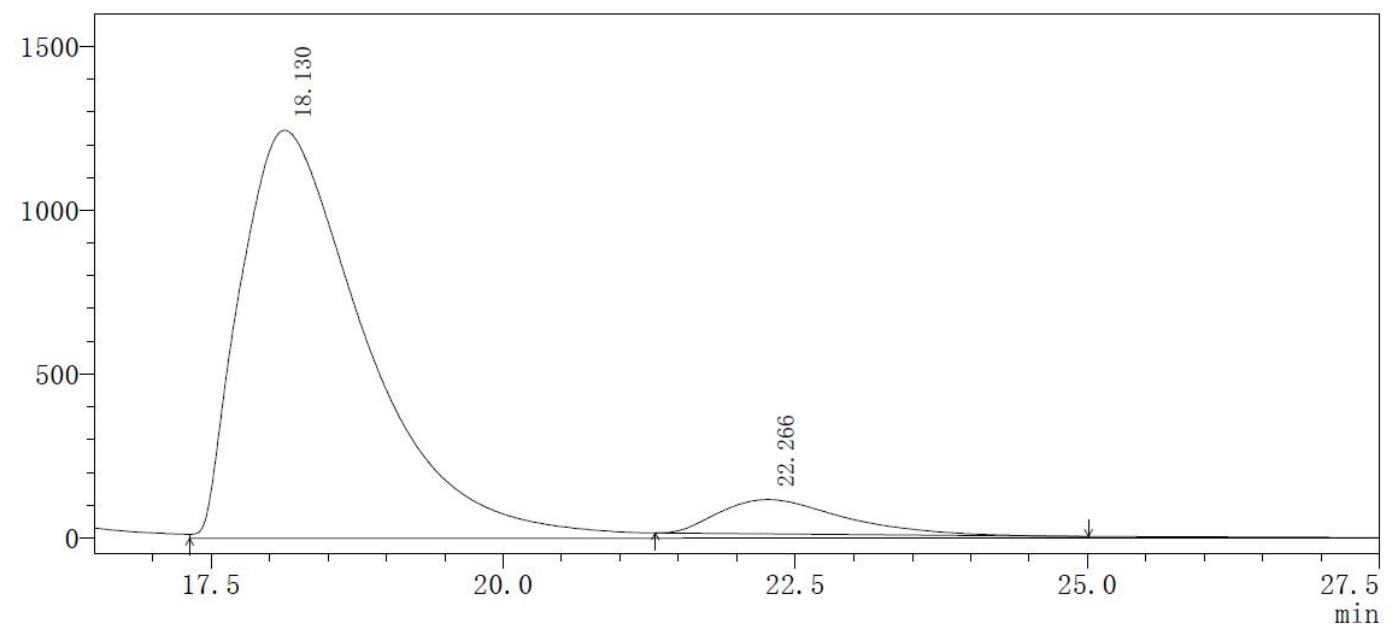

\begin{tabular}{|c|c|c|c|c|c|c|}
\hline \\
\hline ID\# & Start & End & Ret. Time & Height & Area & Area\% \\
\hline 1 & 17. 317 & 32.458 & 18.130 & 1245805 & 96142727 & 92.488 \\
\hline 2 & 21.300 & 25.008 & 22.266 & 105006 & 7809198 & 7.512 \\
\hline & & & & 1350811 & 103951925 & 100.000 \\
\hline
\end{tabular}




\section{Figure S25. MS spectra}
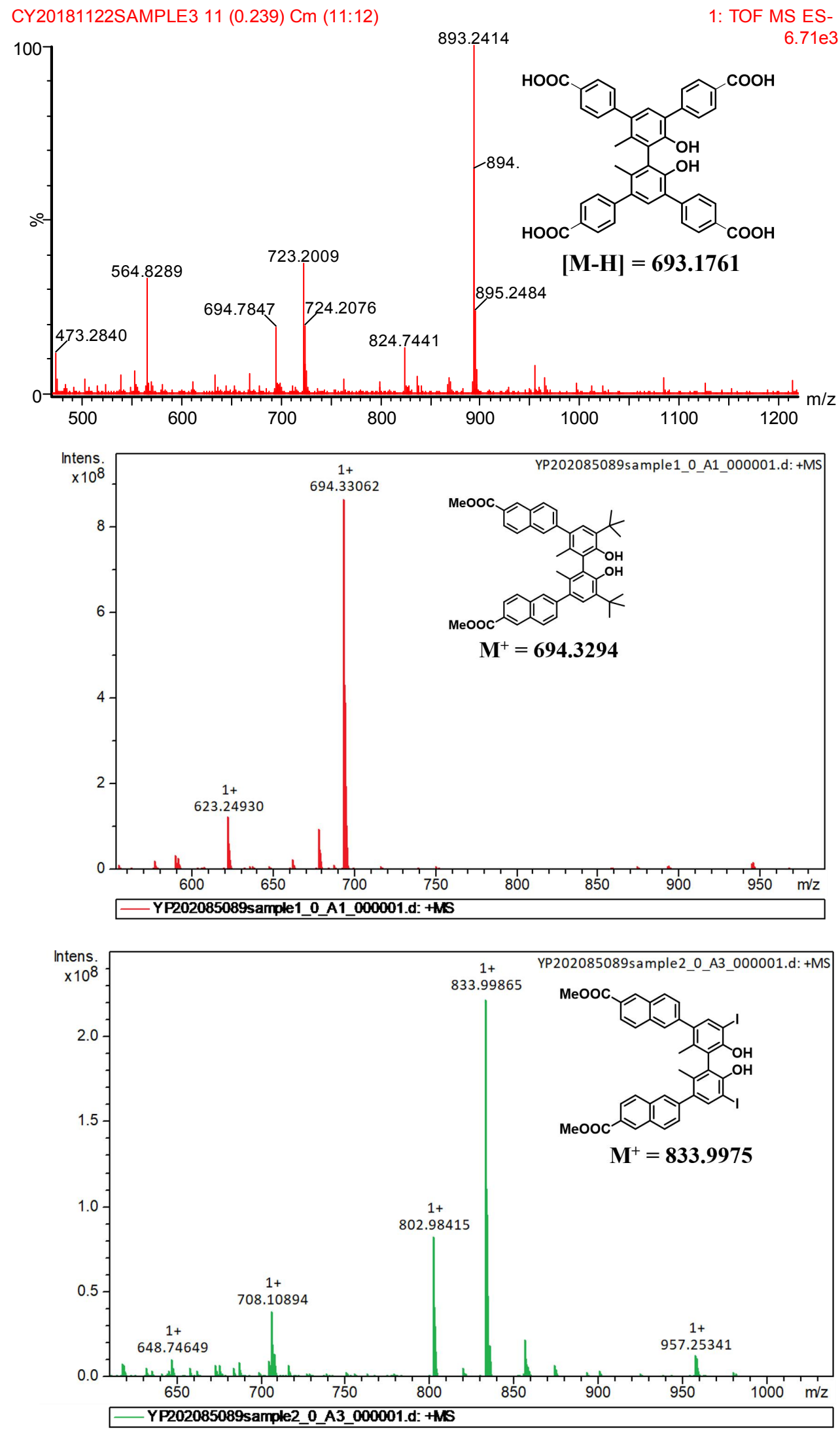


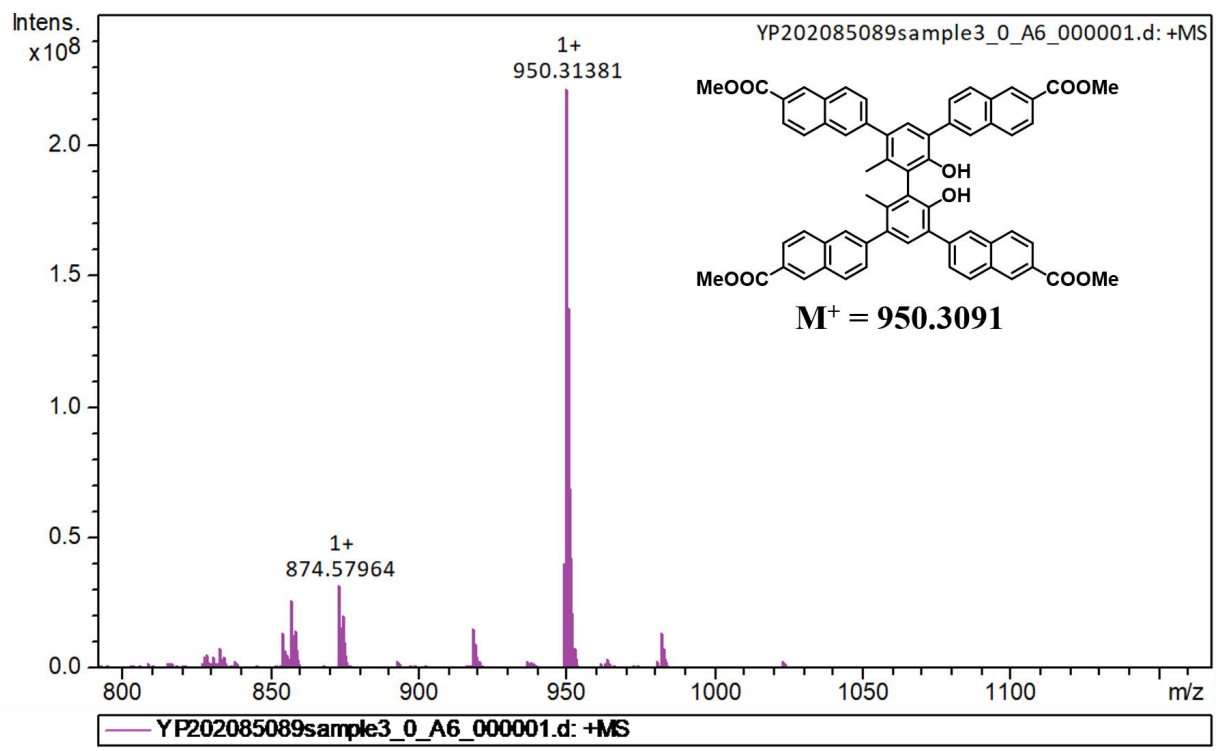

CY20181122SAMPLE3 11 (0.239) Cm (11:12)
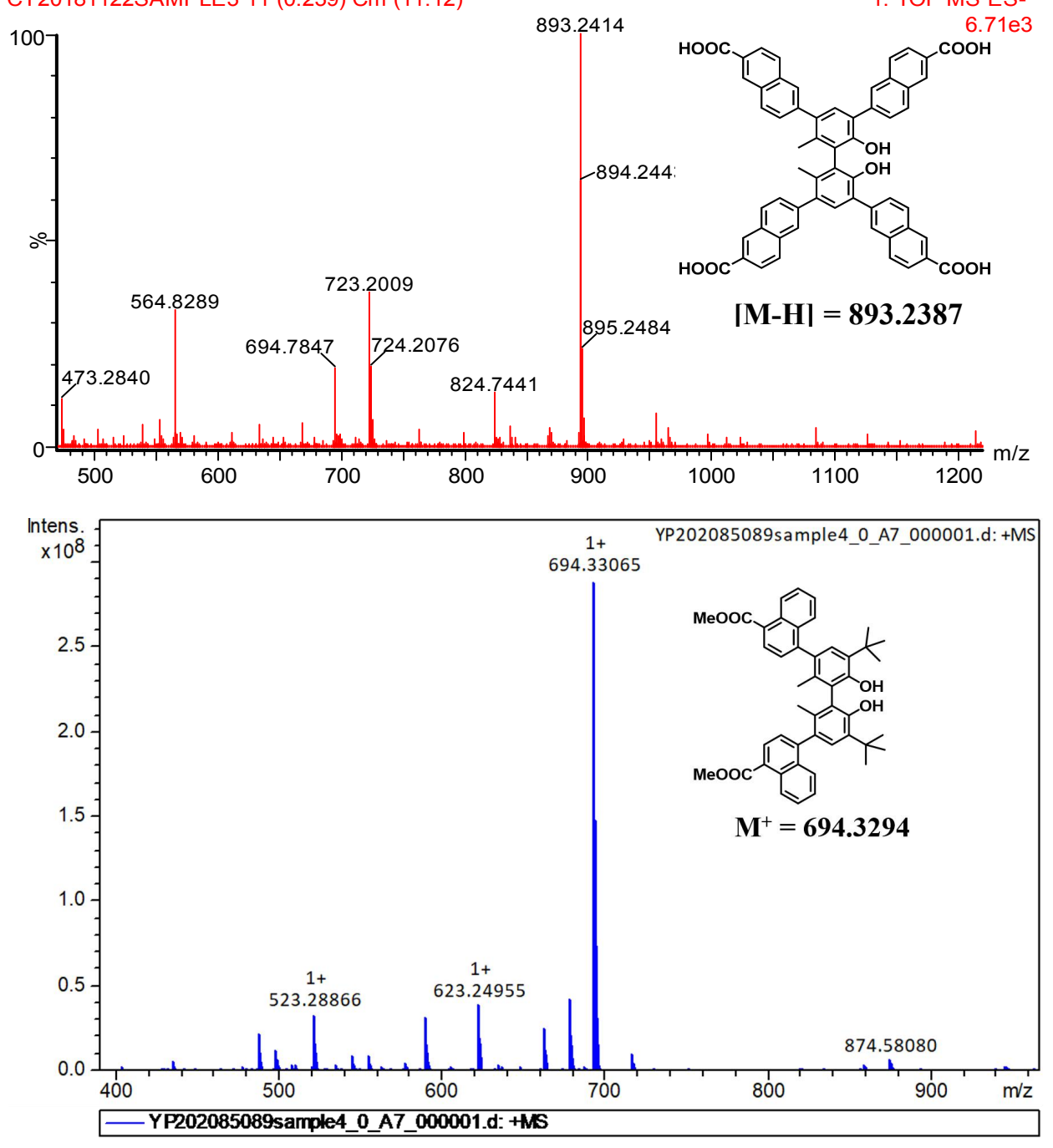

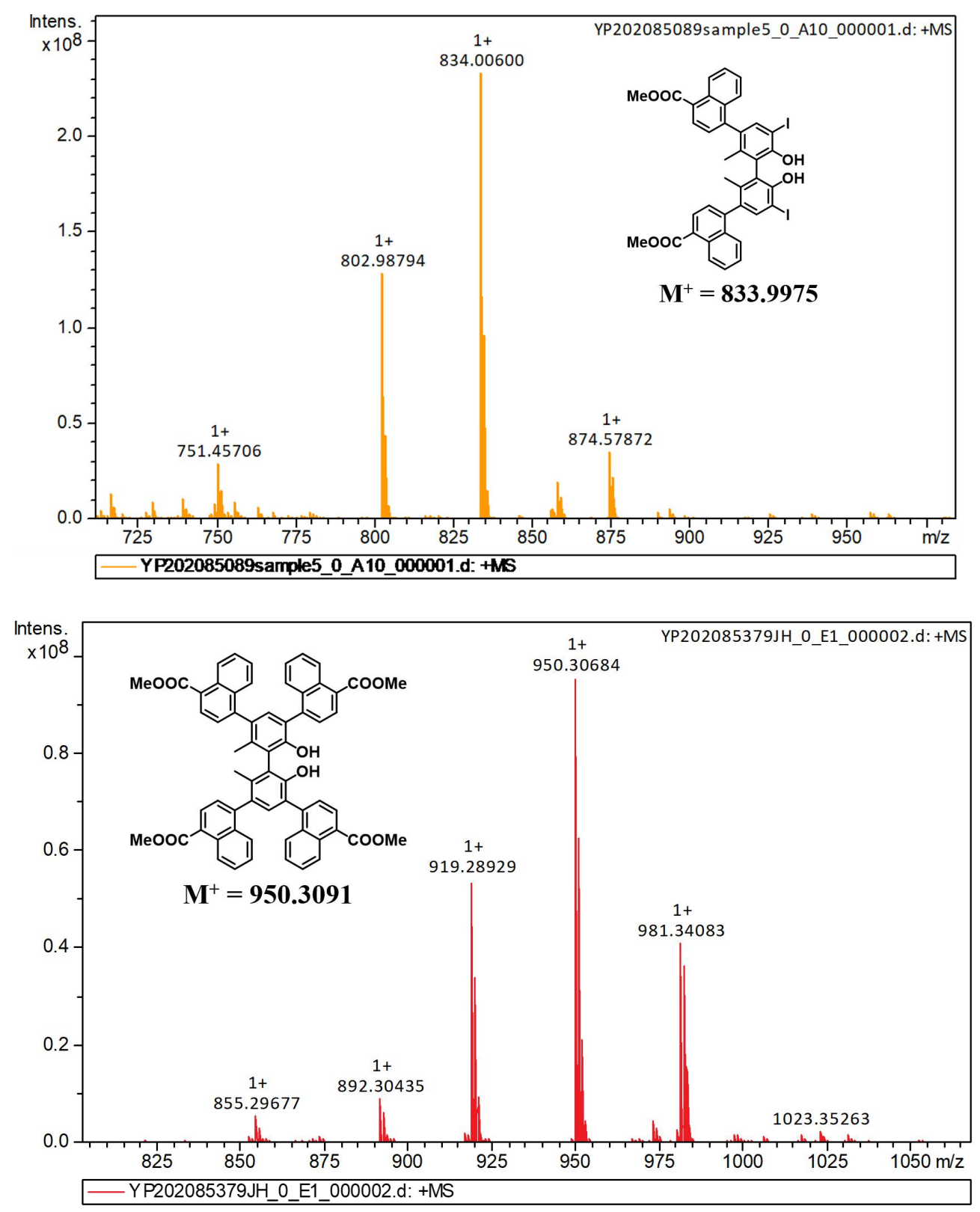

CY20181122SAMPLE4 13 (0.285) Cm (13:15)

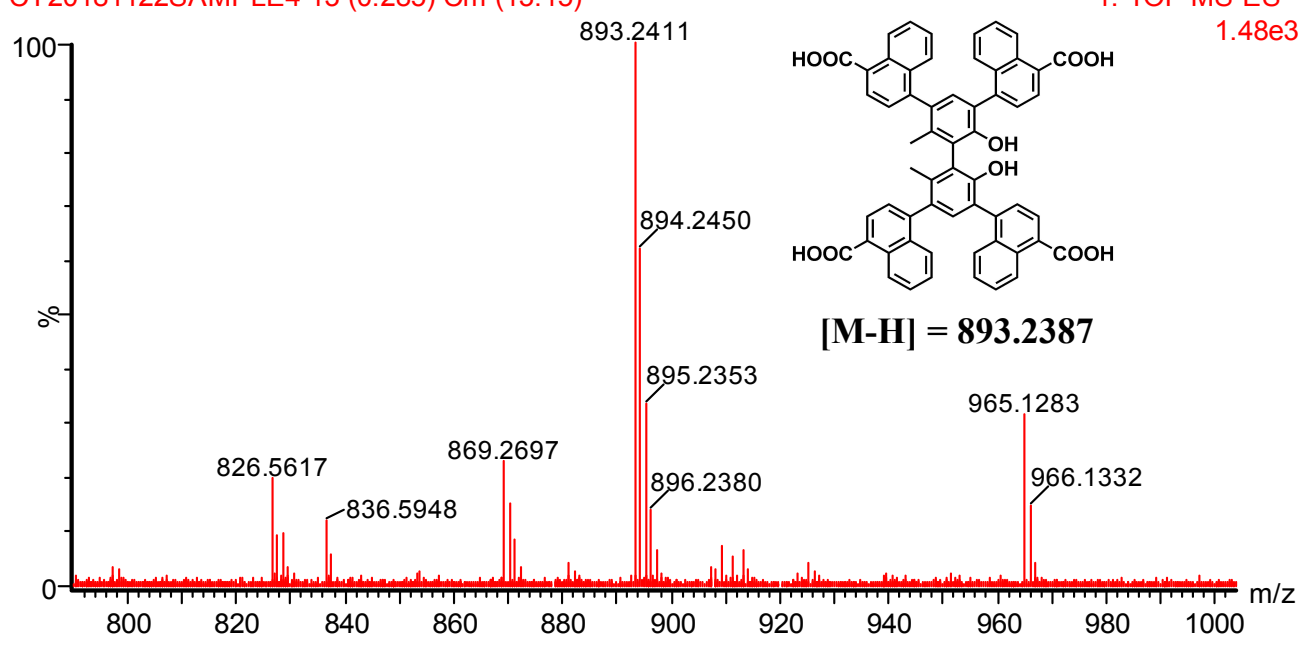



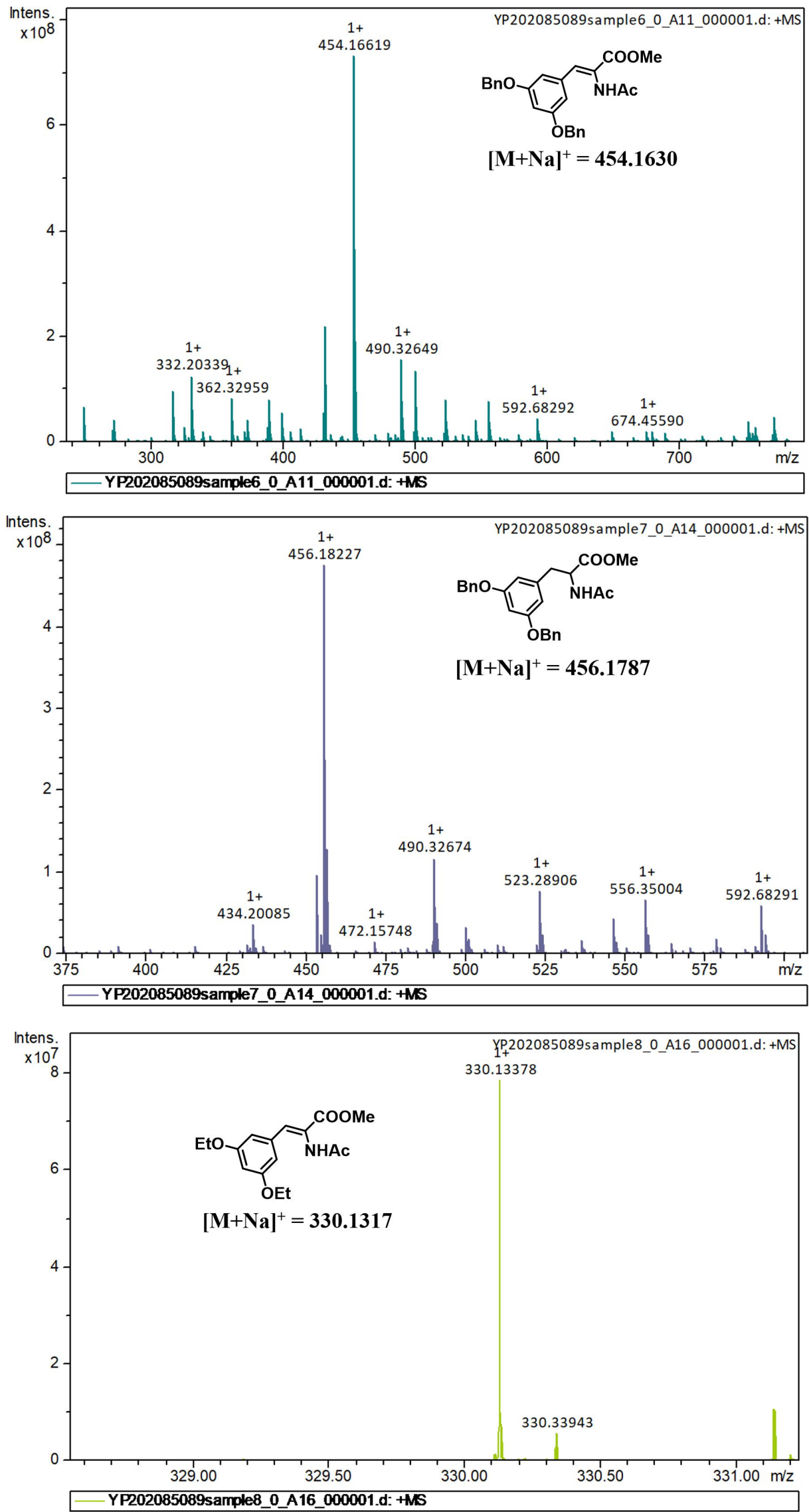

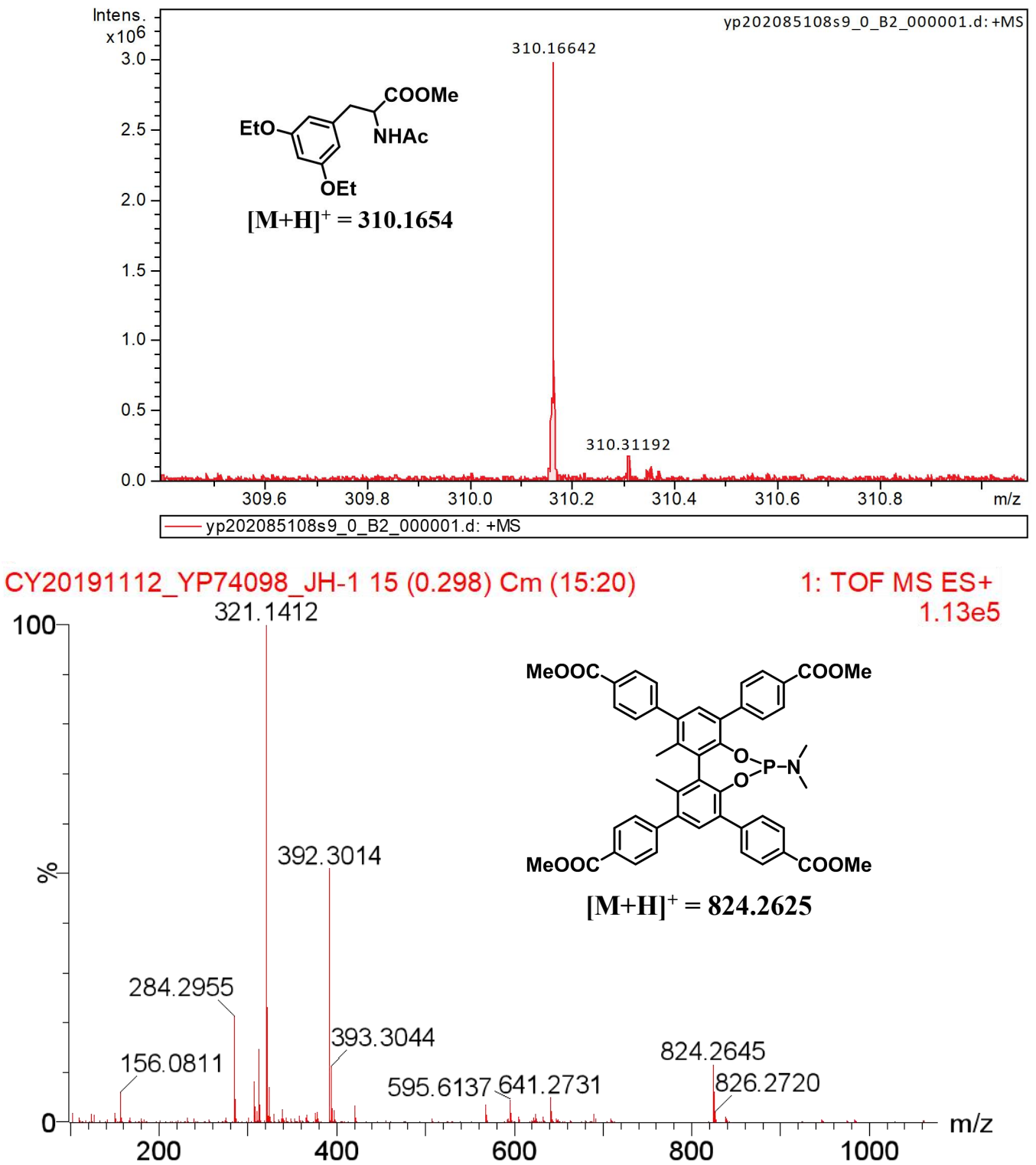

CY20191112_YP74098_JH-2 15 (0.298) Cm (14:20)

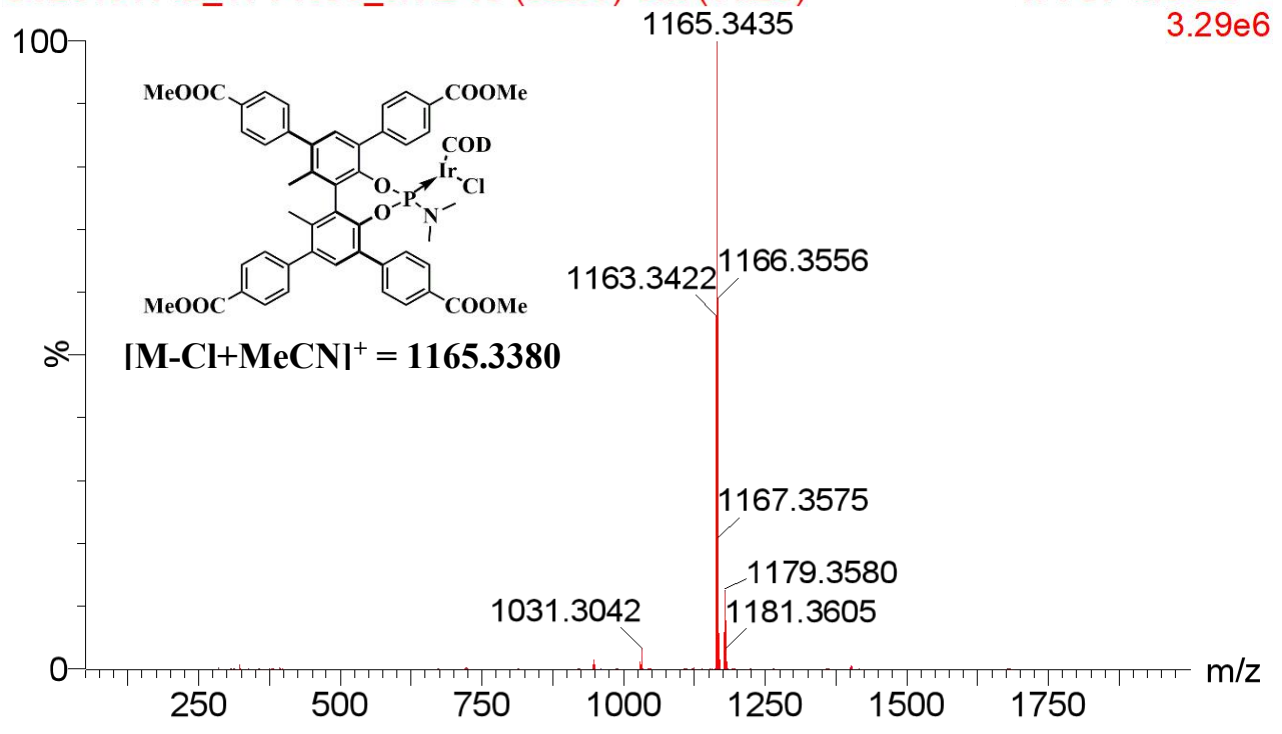




\section{References}

(1) Chen, X.; Jiang, H.; Hou, B.; Gong, W.; Wu, X.; Han, X.; Zheng, F.; Liu, Y.; Jiang, J.; Cui, Y. Chiral Phosphoric Acids in Metal-Organic Frameworks with Enhanced Acidity and Tunable Catalytic Selectivity. Angew. Chem. Int. Ed. 2019, 58, 14748-14757.

(2) Jia, J.; Ling, Z.; Zhang, Z.; Tamura, K.; Gridnev, I. D.; Imamoto, T.; Zhang, W. An Atropos Chiral Biphenyl Bisphosphine Ligand Bearing Only 2,2'-Substutuents and Its Application in Rh-Catalyzed Asymmetric Hydrogenation. Adv. Synth. Catal. 2018, 360, 738-743.

(3) Storch, G.; Trapp, O. Temperature-Controlled Bidirectional Enantioselectivity in a Dynamic Catalyst for Asymmetric Hydrogenation. Angew. Chem. Int. Ed. 2015, 54, 3580-3586. 